Portland State University

PDXScholar

Summer 8-1-2016

\title{
Improving the Roadside Environment through Integrating Air Quality and Traffic-Related Data
}

Christine M. Kendrick

Portland State University

Follow this and additional works at: https://pdxscholar.library.pdx.edu/open_access_etds

Part of the Environmental Health Commons, and the Environmental Sciences Commons Let us know how access to this document benefits you.

\section{Recommended Citation}

Kendrick, Christine M., "Improving the Roadside Environment through Integrating Air Quality and TrafficRelated Data" (2016). Dissertations and Theses. Paper 3086.

https://doi.org/10.15760/etd.3081

This Dissertation is brought to you for free and open access. It has been accepted for inclusion in Dissertations and Theses by an authorized administrator of PDXScholar. Please contact us if we can make this document more accessible: pdxscholar@pdx.edu. 
Improving the Roadside Environment through Integrating Air Quality and Traffic-

Related Data

by

Christine M. Kendrick

A dissertation submitted in partial fulfillment of the requirements for the degree of

Doctor of Philosophy

in

Environmental Sciences and Resources

Dissertation Committee:

Linda A. George, Chair

Dean Atkinson

Christopher Butenhoff

Kelly Clifton

Portland State University

2016 


\begin{abstract}
Urban arterial corridors are landscapes that give rise to short and long-term exposures to transportation-related pollution. With high traffic volumes, congestion, and a wide mix of road users and land uses at the road edge, urban arterial environments are important targets for improved exposure assessment to traffic-related pollution. Applying transportation management strategies to reduce emissions along arterial corridors could be enhanced if the ability to quantify and evaluate such actions was improved. However, arterial roadsides are under-sampled in terms of air pollution measurements in the United States and using observational data to assess such effects has many challenges such as lack of control sites for comparisons and temporal autocorrelation. The availability of traffic-related data is also typically limited in air monitoring and health studies. The work presented here uses unique long-term roadside air quality monitoring collected at the intersection of an urban arterial in Portland, OR to characterize the roadside atmospheric environment. This air quality dataset is then integrated with traffic-related data to assess various methods for improving exposure assessment and the roadside environment.

Roadside nitric oxide (NO), nitrogen dioxide $\left(\mathrm{NO}_{2}\right)$, and particle number concentration (PNC) measurements all demonstrated a relationship with local traffic volumes. Seasonal and diurnal characterizations show that roadside $\mathrm{PM}_{2.5}$ (mass) measurements do not have a relationship with local traffic volumes, providing evidence that $\mathrm{PM}_{2.5}$ mass is more tied to regional sources and meteorological conditions. The relationship of roadside $\mathrm{NO}$ and $\mathrm{NO}_{2}$ with traffic volumes was assessed over short and long-term aggregations to assess the reliability of a commonly employed method of using


traffic volumes as a proxy for traffic-related exposure. This method was shown to be insufficient for shorter-time scales. Comparisons with annual aggregations validate the use of traffic volumes to estimate annual exposure concentrations, demonstrating this method can capture chronic but not acute exposure. As epidemiology and exposure assessment aims to target health impacts and pollutant levels encountered by pedestrians, cyclists, and those waiting for transit, these results show when traffic volumes alone can be a reliable proxy for exposure and when this approach is not warranted.

Next, it is demonstrated that a change in traffic flow and change in emissions can be measured through roadside pollutant concentrations suggesting roadside pollution can be affected by traffic signal timing. The effect of a reduced maximum traffic signal cycle length on measurements of degree of saturation (DS), $\mathrm{NO}$, and $\mathrm{NO}_{2}$ were evaluated for the peak traffic periods in two case studies at the study intersection. In order to reduce bias from covariates and assess the effect due to the change in cycle length only, a matched sampling method based on propensity scores was used to compare treatment periods (reduced cycle length) with control periods (no change in cycle length). Significant increases in DS values of $2-8 \%$ were found along with significant increases of 5-8ppb NO and 4-5ppb $\mathrm{NO}_{2}$ across three peak periods in both case studies. Without matched sampling to address the challenges of observational data, the small DS and NOx changes for the study intersection would have been masked and matched sampling is shown to be a helpful tool for future urban air quality empirical investigations.

Dispersion modeling evaluations showed the California Line Source Dispersion Model with Queuing and Hotspot Calculations (CAL3QHCR), an approved regulatory 
model to assess the impacts of transportation projects on $\mathrm{PM}_{2.5}$, performed both poor and well when predictions were compared with $\mathrm{PM}_{2.5}$ observations depending on season. Varying levels of detail in emissions, traffic signal, and traffic volume data for model inputs, assessed using three model scenarios, did not affect model performance for the study intersection. Model performance is heavily dependent on background concentrations and meteorology. It was also demonstrated that CAL3QHC can be used in combination with roadside PNC measurements to back calculate PNC emission factors for a mixed fleet and major arterial roadway in the U.S.

The integration of roadside air quality and traffic-related data made it possible to perform unique empirical evaluations of exposure assessment methods and dispersion modeling methods for roadside environments. This data integration was used for the assessment of the relationship between roadside pollutants and a change in a traffic signal setting, a commonly employed method for transportation management and emissions mitigation, but rarely evaluated outside of simulation and emissions modeling. Results and methods derived from this work are being used to implement a second roadside air quality station, to design a city-wide integrated network of air quality, meteorological, and traffic data including additional spatially resolved measurements with feedback loops for improved data quality and data usefulness. Results and methods are also being used to design future evaluations of transportation projects such as freight priority signaling, improved transit signal priority, and to understand the air quality impacts of changes in fleet composition such as an increase in electric vehicles. 


\section{Acknowledgements}

Many thanks to my advisor, Dr. Linda A. George, for providing thoughtful advice, support, encouragement, and numerous opportunities to learn a variety of skills and participate in a variety of projects throughout my time at Portland State University. I also thank my committee members: Dr. Dean Atkinson, Dr. Christopher Butenhoff, and Dr. Kelly Clifton for their guidance and support throughout this graduate and research journey. I would also like to thank Peter Koonce and other members of the City of Portland's ITS, Signals, and Street Lighting Division for their help and support as I learned about traffic signals and detection and for providing access to signal data to help make this dissertation work possible.

Thank you to all of my lab-mates, especially, Meenakshi Rao and Jacinda Mainord, for all of the support and willingness to edit papers, watch practice presentations, and carry instruments and equipment with me over the years. I would also like to thank my family and friends for their support, patience, and love.

Thank you to all of the following funding support throughout this dissertation:

NITC Dissertation Fellowship Grant

EPA STAR Fellowship Assistance Agreement no. FP917473

NSF GK-12 Cascades to Coast Fellowship Award 094804 


\section{Table of Contents}

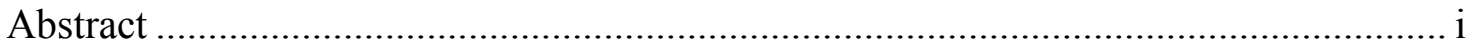

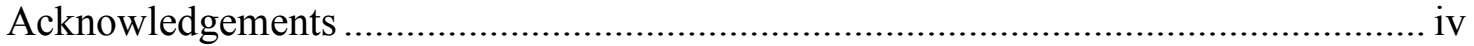

List of Tables................................................................................................... vii

List of Figures ............................................................................................... viii

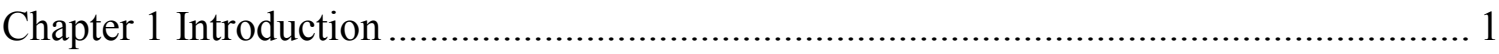

1.1 Background on Near-Road Air Quality Monitoring ...................................... 3

Chapter 2 Diurnal and Seasonal variations of $\mathrm{NO}, \mathrm{NO}_{2}$, and $\mathrm{PM}_{2.5}$ mass as a function of traffic volumes alongside an urban arterial............................................................. 7

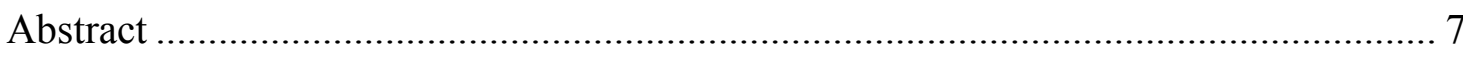

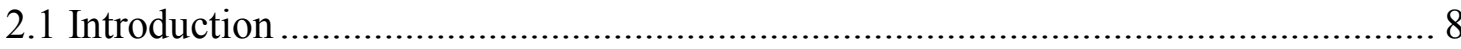

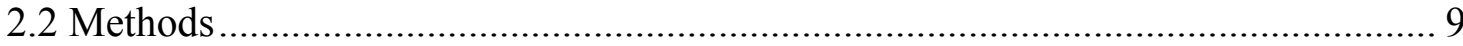

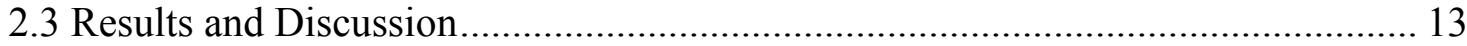

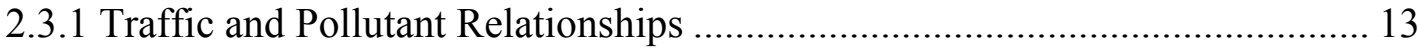

2.3.2 Weekday, Seasonal and Diurnal Characterization of Roadside Pollutant

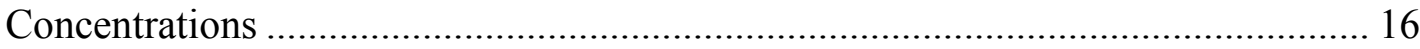

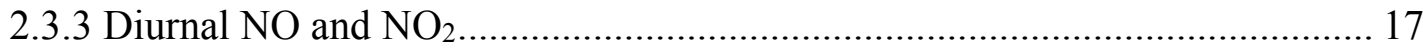

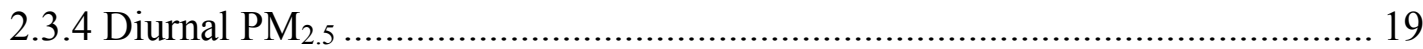

2.3.5 Estimating Roadside NOx as a Function of Traffic Volumes ....................... 21

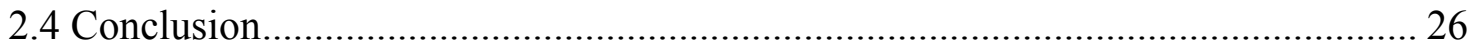

Chapter 3 Assessing the effects of a reduced traffic signal cycle length on roadside NOx

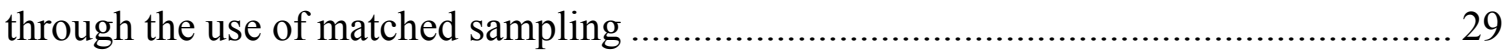

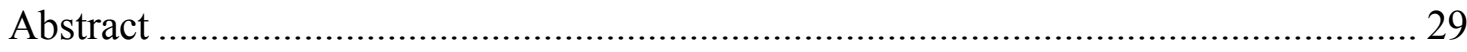

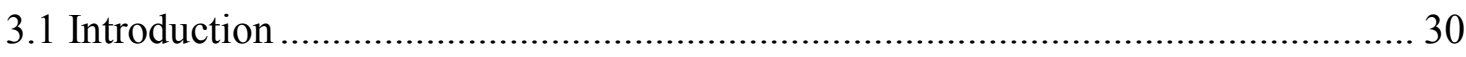

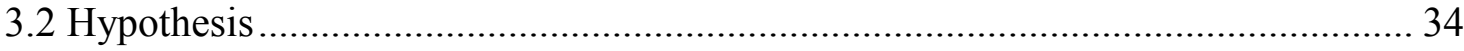

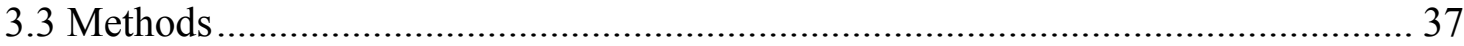

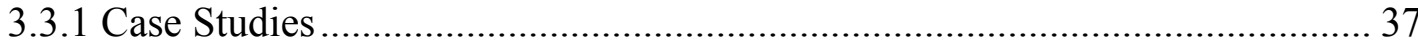

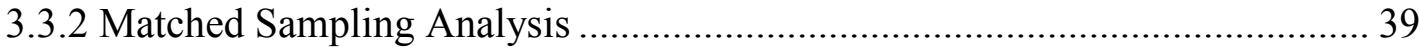

3.3.3 Assessment of Casual Effects ............................................................... 42

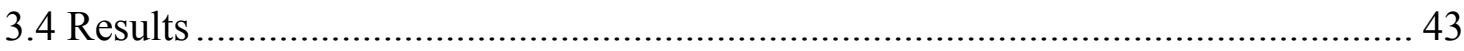

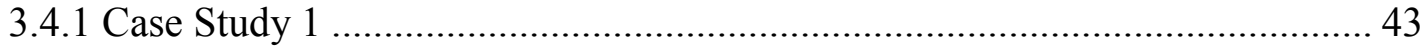


3.4.2 Average Treatment Effect- Case study 1 .................................................. 48

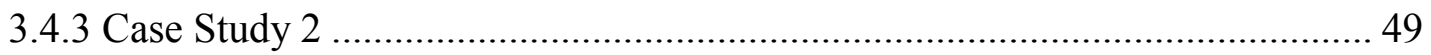

3.4.4 Average treatment effect- Case Study 2 ................................................ 51

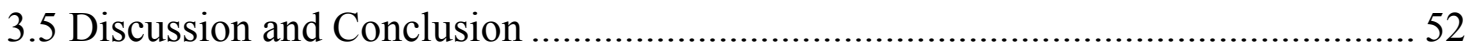

Chapter 4 Evaluation of CAL3QHC dispersion modeling for predicting particulate

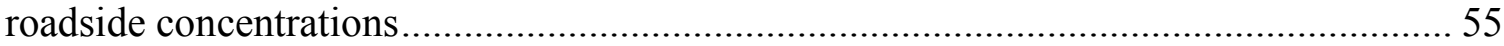

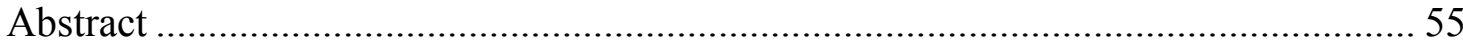

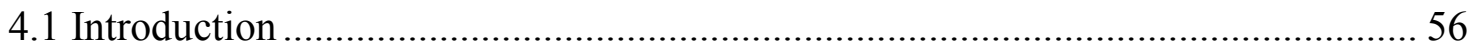

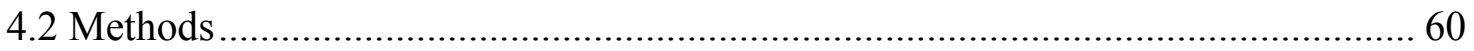

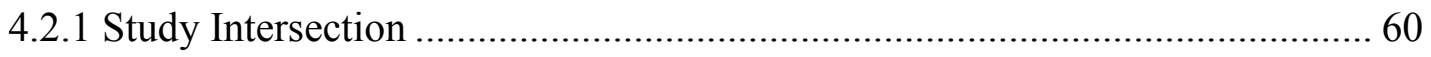

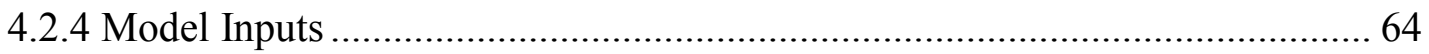

4.2.4 Particle Count Measurements and Modeling ............................................... 70

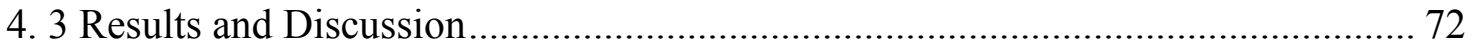

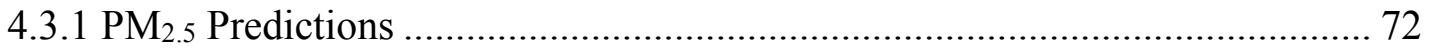

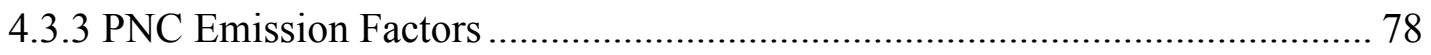

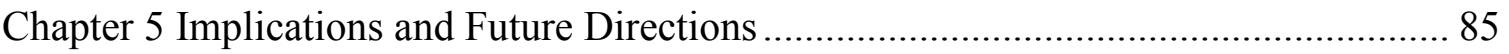

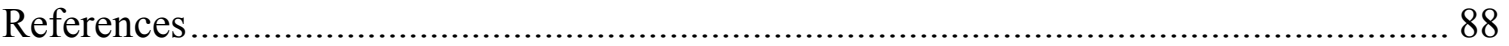

A. Appendix A: Literature Review Tables of Near-Road Air Quality Studies ............... 99

B. Appendix B: Supplemental Plots and Tables for Chapter 3's Matching Analysis .... 109

C. Appendix C: Cascades to Coast GK-12 Curriculum................................................ 139 


\section{List of Tables}

Table 2.1 Roadside and urban background comparisons for weekdays and weekends, spanning Jan 2013- Dec 2013 at 15 minute aggregations.

Table 2.2 Median regression slope coefficients, standard errors and $\mathrm{r}^{2}$ values for roadside NOx as a function of traffic volumes using randomly sampled subset (black) and all serially correlated data points (grey). $* *$ significance at $<0.01$ and $*$ significance at $<0.05$

Table 2.3 Regression results for median annual $\mathrm{NO}$ and $\mathrm{NO}_{2}$ as a function of traffic

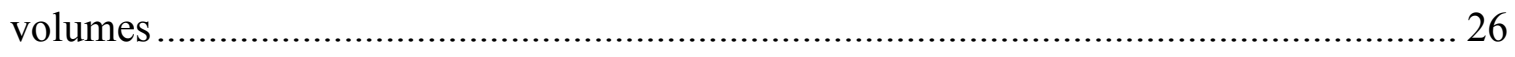

Table 3.1 Description of case studies with reduced HCL............................................. 38

Table 3.2 Case Study 1 Matching diagnostics for total samples matched. Numbers in parentheses are for the full dataset.

Table 3.3 Case study 1 Summary of correlation coefficients between time-lagged response variables to reduce temporal autocorrelation for Case Study 1 evaluation periods.

Table 3.4 Case Study 2 Matching diagnostics for total samples matched. Numbers in parentheses are for the full datasets.

Table 3.5 Summary of correlation coefficients between time-lagged response variables to reduce temporal autocorrelation for Case Study 2 evaluation periods.

Table 4.1 Summaries of roadside and urban background $\mathrm{PM}_{2.5}$ observations for the modeled dates and times.

Table 4.2 Model scenarios based on varying levels of detail available in emissions, traffic, and signal data for modeling inputs.

Table 4.3 Summary of hourly averaged speeds and emission factors (EF) for all model scenarios.

Table 4.4 Range of predicted $\mathrm{PM}_{2.5}\left(\mu \mathrm{g} / \mathrm{m}^{3}\right)$ from traffic for each peak hour by season. 72 Table 4.5 Percentage of points falling within the factor of two envelope for all 3 scenarios and winter time periods. 76

Table 4.6 Percentage of points falling within the factor of two envelope for all 3 scenarios and summer time periods. 76

Table 4.7 Comparison of urban roadway particle number emission factors from field studies. 


\section{List of Figures}

Figure 2.1 Schematic of study intersection. Air quality monitoring cabinet (purple circle) is located on the SW corner of Powell Blvd which runs E/W and SE 26th Ave runs N/S.

Figure 2.2 All weekday roadside pollutant measurements versus traffic volumes. White triangles show the median relationship of each pollutant with traffic volume bins of fifty.

Figure 2.3 Weekday, seasonal diurnal distributions for (a) traffic volumes, (b-f) roadside $\mathrm{NO}, \mathrm{NO}_{2}$, wind speed, $\mathrm{PM}_{2.5}$, and relative humidity, and (g-k) urban background $\mathrm{NO}$, $\mathrm{NO}_{2}$, wind speed, $\mathrm{PM}_{2.5}$, and relative humidity. Colored lines represent the $50^{\text {th }}$ percentile and the black lines are the $10^{\text {th }}$ and $90^{\text {th }}$ percentile.

Figure 2.4 Median regression relationships of traffic volumes and roadside $\mathrm{NO}_{2}$ given season and morning and evening peak periods.

Figure 2.5 Median roadside $\mathrm{NO}_{2}$ as a function of traffic volumes binned by 50 vehicles across the entire year.

Figure 3.1 Relationship of degree of saturation and traffic volumes for the study intersection. 36

Figure 3.2 Relationship of NOx versus DS for the study intersection. Red points represent the median NOx concentration for every $10 \%$ increase in DS.

Figure 3.3 Case study 1 with a $20 \mathrm{sec}$ reduction in HCL. Control samples points are in grey, treatment sample points in black, and rush hour periods highlighted in yellow. .... 44 Figure 3.4 Example of QQ plots used to asses balance in matched samples for morning Case Study 1.

Figure 3.5 Histograms of propensity score values for the control and treatment sample points in the final matched sample for morning case study 1 .

Figure 3.6 Case study 2 with a $15 \mathrm{sec}$ reduction in HCL. Control samples points are in grey, treatment sample points in black, and evening rush hour period highlighted in yellow.

Figure 4.1 SE Powell Blvd and SE $26^{\text {th }}$ Ave intersection setup with links and receptors for dispersion modeling.

Figure 4.2 Windroses for January and July peak hours modeled

Figure 4.3 Weekday and weekend PNC diurnal distributions. Purple line is the 50th percentile, black lines are the 10th and 90th percentile, and individual points in light grey.

Figure 4.4 Predicted $\mathrm{PM}_{2.5}$ versus wind speed for model scenario 2. Transparent orange represents predictions when wind speed is $<1 \mathrm{~m} / \mathrm{s}$ and transparent black represents predictions when wind speeds $>1 \mathrm{~m} / \mathrm{s}$. Darker colors on the plot show overlapping points.

Figure 4.5 Predicted versus observed $\mathrm{PM}_{2.5}$ for winter peak hours and receptor 1 (SW corner) only, (a) Scenario 1, (b) Scenario 2, and (c) Scenario 3 model setup. 74 
Figure 4.6 Predicted versus observed $\mathrm{PM}_{2.5}$ for winter peak hours and all four corner receptors, (a) Scenario 1, (b) Scenario 2, and (c) Scenario 3 model setup..................... 75 Figure 4.7 Predicted versus observed $\mathrm{PM}_{2.5}$ for summer peak hours and receptor 1 (SW corner) only, (a) Scenario 1, (b) Scenario 2, and (c) Scenario 3 model setup................. 75 Figure 4.8 Predicted versus observed $\mathrm{PM}_{2.5}$ for summer peak hours and all four corner receptors, (a) Scenario 1, (b) Scenario 2, and (c) Scenario 3 model setup. 75 Figure 4.9 CAL3QHC derived particle emission factors for morning and evening peak hours when PNC measurements occurred. ................................................................. 79 
Chapter 1 Introduction

Transportation-related emissions are a significant source of air pollution in urban areas. Increasing urbanization worldwide ${ }^{1}$ and growth in high density development ${ }^{2}$ will both lead to more people who reside, work, attend school, and commute within a nearroad environment. More than four-fifths of the United States population currently resides in metropolitan areas and from 2000 to 2010 population growth rates for metropolitan areas were greater than the national rate ${ }^{3}$. Elevated concentrations of traffic-related pollution such as nitric oxide $(\mathrm{NO})$, nitrogen dioxide $\left(\mathrm{NO}_{2}\right)$, and particle number concentrations (PNC) surrounding major roadways have been well documented ${ }^{4-7}$. Adverse respiratory and cardiovascular effects for populations living within this near roadway environment have been shown through epidemiology and toxicology evidence 4,8,9. Short-term exposures as experienced by drivers, vehicle occupants, cyclists or pedestrians are also associated with short-term morbidity and negative health responses $10-12$.

In recognition of this heterogeneous pattern of traffic-related pollution and increased health impacts, the United States Environmental Protection Agency (U.S. EPA) has made the one hour $\mathrm{NO}_{2}$ National Ambient Air Quality Standard more stringent and mandated roadside monitoring of $\mathrm{NO}_{2}$ in population centers greater than 500,000 residents ${ }^{13}$. This new roadway monitoring network is primarily sited near major highways and will also include measurements of $\mathrm{PM}_{2.5}$ mass and $\mathrm{CO}^{14}$. Major urban arterial roadways represent $1.9 \%$ of total miles in the U.S., but account for at least $57.8 \%$ 
of urban traffic ${ }^{15}$. This urban arterial system contains high traffic volumes, but unlike highways, also contains a high compositional mix of road users such as those waiting at a transit stop, walking within the corridor, and also bicyclists. This transportation microenvironment also contains a variety of land uses including residential, school, park, or commercial located directly at the edge of the roadway. Close proximity to traffic results in higher exposure concentrations to traffic-related pollution for all road users ${ }^{16-}$ ${ }^{20}$. There is also potential for increased uptake of traffic related pollution for bicyclists and pedestrians due to increased respiration rates or longer travel times ${ }^{19,21,22}$. The urban arterial micro-environment is an important and dominant feature of cities, and is a key location for increased exposures to traffic-related pollution but remains an undermeasured microenvironment.

Public health practitioners, urban planners, and transportation engineers are looking for ways to reduce the impacts of arterial roadways on public health. Arterial roadway environments present opportunities to apply innovative corridor planning, traffic management, transit services and urban design but the impacts of such methods are rarely quantified ${ }^{23}$. This view of arterial roadways as targets for adaptation and change is one of the primary motivations for a Task Force on Arterials and Public Health by the Transportation Research Board Technical Activities Council. Applying transportation innovations to mitigate emissions along roadways and across transportation systems requires the ability to quantify and evaluate such actions. Assessing new ways to collect and use information to design and operate systems and services is a key recommendation of the President's Council of Advisors on Science and Technology 2016 report 
"Technology and The Future of Cities" ${ }^{24}$. One example of a traffic operation strategy frequently applied to arterial roadways is traffic signal coordination to smooth traffic flows, mitigate congestion, reduce fuel consumption and reduce air pollution ${ }^{25-28}$. Impacts of innovative operation strategies such as signal coordination or other techniques likes changing roadway design and shifting mode shares are typically evaluated using a combination of traffic simulation, emissions, and dispersion modeling but it is rare to evaluate such changes with empirical findings. Additionally, arterial roadsides are undersampled in terms of air pollution measurements in the U.S and using observational data to assess such changes has many challenges such as high variability in covariates, nonrandomized study design, temporal autocorrelation and lack of control case studies for comparisons. The availability of traffic-related data is also typically limited in air monitoring and health studies. The work presented here uses unique long-term roadside air quality monitoring collected at the intersection of a major urban arterial in Portland, OR to characterize the roadside atmospheric environment. This air quality dataset is then integrated with traffic-related data to assess various methods for improving exposure assessment and the roadside environment.

\subsection{Background on Near-Road Air Quality Monitoring}

Urban arterial roadways are under-sampled in terms of air quality in the U.S. and near roadway monitoring studies are typically conducted on short time scales such as weeks or months. To our knowledge, the only near road air quality studies using a longterm curbside station have been conducted outside of North America and primarily within 
European Union countries with different fuel use and vehicle fleets than U.S. cities (Appendix A, Table A-1). Other strategies typically employed in near road air quality research include making measurements perpendicular from the road at increasing distance to understand the spatial extent of traffic-related pollution (Appendix A, Table A-2) and mobile measurements made within the roadway to develop emission factors under real-world driving conditions and the contribution of in-car exposure to total exposure $^{29,30}$.

The curbside monitoring studies shown in Table A-1 have a wide range of study lengths ( 4 day to 25 years). Curbside monitoring has been a part of some European Union air quality networks for quite some time as a requirement within the national monitoring networks that also include urban background, suburban, and rural measurements. In some examples, data from such stations have been used in research in addition to their initial regulatory purpose. Long-term, curbside monitoring has been used to document longterm trends in specific pollutants and pollutant ratios, and/or comparison of pollutant concentrations between different types of land use ${ }^{31-34}$.

There is one example where a curbside station in London (the Marylebone Road supersite, part of the London Air Quality Network operated by the Environmental Research Group of Kings College) was used as the field piece for a much larger scale research project called Dispersion of Air Pollution and its Penetration into the Local Environment (DAPPLE). The DAPPLE project focused on advanced flow and dispersion modeling along with road-user exposure assessment in a street canyon environment with larger goals of using such dispersion modeling to characterize small-scale urban 
atmospheric dispersion and evaluate sustainable development goals in terms of changes to air quality exposures ${ }^{35,36}$. The research presented in the following sections is similar in that our field station can be used to characterize small scale air quality exposures and assess how some transportation decisions affect roadside pollution through evaluating the relationships of traffic signalization with roadside pollution. However, this research is focused on a more open arterial and not a street canyon environment.

In contrast to Table A-1, most projects in Table A-2 that investigated the distance at which traffic-related pollutants reach background concentrations away from roadways have occurred in the U.S. This type of near road monitoring primarily occurs in highway environments and has provided critical information about the spatial extent of increased pollution due to traffic. Table A-2 is not an exhaustive list of near roadway studies and Karner et al $(2010)^{5}$ and Zhou and Levy $(2007)^{6}$ can be referred to for meta-analyses of distance decay relationships of traffic-related pollutants.

Long-term projects using this measurement strategy for up to one full year of data collection are Federal Highway Administration (FHWA) and EPA sponsored projects at Las Vegas, Nevada and Detroit, MI along with a pilot projects by the EPA in Brooklyn, $\mathrm{NY}$ and Raleigh, $\mathrm{NC}^{37,38}$. These year-long projects have helped to support EPA's $\mathrm{NO}_{2}$ regulatory decisions, develop guidance for the new monitoring network, document correlation between pollutants, test implementation of new measurement technologies, establish important datasets to be used with modeling and toxicology studies, model the infiltration process of pollutants to the indoor environment, and increased understanding of how barriers like sound walls affect dispersion (Table A-2). Other work of this nature 
done in California and Texas have presented novel information about the presence of ultrafine particles in the near road environment ${ }^{39-45}$.

Data from the studies in Table A-2 have provided a wealth of new information about pollutant behavior surrounding highways, but do not necessarily describe a U.S. urban arterial environment. The EPA's Brooklyn project named the Brooklyn Traffic Real-time Ambient Pollutant Penetration and Environmental Dispersion (B-TRAPPED) project did involve short-term measurements for an urban environment but not long-term characterization of roadside pollutants. The focus of B-TRAPPED was to assess the highway's zone of influence and also to measure and model the dispersion of a contaminant through an urban street canyon, the flux onto a single receptor building in the canyon, and then the infiltration into a three-story, receptor building to understand traffic-related pollution but also the possible movement of an intentional release of a substance into a dense urban area ${ }^{46,47}$. The study also employed the use of wind tunnel studies and computational fluid dynamic (CFD) modeling similar to DAPPLE ${ }^{48,49}$.

The near-road air quality monitoring conducted to support this dissertation follows the curbside model of studies presented in Table A-1 with continuous measurements of $\mathrm{NO}, \mathrm{NO}_{2}, \mathrm{PM}_{2.5}$ mass, and episodic measurements of PNC directly at the road edge of a signalized intersection. Simultaneous traffic volume, measures of traffic congestion, and signal timing data are also collected though the adaptive traffic signal system operating on the study corridor. It is unique to have all of these components on a long-term scale for a study at a U.S. arterial roadside. Monitoring station setup and data collection methods are described in detail in section 2.2. 
Chapter 2 Diurnal and Seasonal variations of $\mathrm{NO}, \mathrm{NO}_{2}$, and $\mathrm{PM}_{2.5}$ mass as a function of traffic volumes alongside an urban arterial

The bulk of the material presented in this Chapter was published in:

Kendrick, C.M., Koonce, P., and L.A. George, Diurnal and Seasonal variations of NO, $\mathrm{NO}_{2}$, and $\mathrm{PM}_{2.5}$ mass as a function of traffic volumes alongside an urban arterial. Atmospheric Environment, 122, 133-141 (2015) ${ }^{50}$.

Abstract

Urban arterial corridors are landscapes that give rise to short and long-term exposures to transportation-related pollution. With high traffic volumes and a wide mix of road users, urban arterial environments are important targets for improved exposure assessment to traffic-related pollution. A common method to estimate exposure is to use traffic volumes as a proxy. The study presented here analyzes a unique yearlong dataset of simultaneous roadside air quality and traffic observations for a U.S. arterial to assess the reliability of using traffic volumes as a proxy for traffic-related exposure. Results show how the relationships of traffic volumes with $\mathrm{NO}$ and $\mathrm{NO}_{2}$ vary not only by time of day and season but also by time aggregation. At short-term aggregations (15 minutes) nitrogen oxides were found to have a significant linear relationship with traffic volumes during morning hours for all seasons although variability was still high $\left(\mathrm{r}^{2}=0.1-0.45\right.$ for $\mathrm{NO}, \mathrm{r}^{2}=0.14-0.27$ for $\left.\mathrm{NO}_{2}\right)$, and little to no relationship during evening periods $\left(\mathrm{r}^{2}<0.01\right.$ - 0.03 for $\mathrm{NO}, \mathrm{r}^{2}<0.01-0.05$ for $\mathrm{NO}_{2}$ ). Comparisons with annual aggregations validate the use of traffic volumes to estimate annual exposure concentrations for morning periods $\left(\mathrm{r}^{2}=0.89\right.$ for $\mathrm{NO}, \mathrm{r}^{2}=0.87$ for $\left.\mathrm{NO}_{2}\right)$ and evening $\mathrm{NO}_{2}\left(\mathrm{r}^{2}=0.46\right)$. Traffic volumes are a 
weak or poor predictor for annual evening NO $\left(r^{2}=-0.09\right)$ and short-term 15 minute aggregations, particularly evening periods. Seasonal and diurnal characterizations show that roadside $\mathrm{PM}_{2.5}$ (mass) measurements do not have a relationship with local traffic volumes, leading us to conclude that $\mathrm{PM}_{2.5}$ mass is more tied to regional sources and meteorological conditions. As epidemiology and personal exposure assessment research aims to study health impacts and pollutant levels encountered by pedestrians, bicyclists, those waiting for transit, and other road users, these results show when traffic volumes alone can be a reliable proxy for exposure and when this approach is not warranted.

\subsection{Introduction}

Roadside measurements are used to characterize diurnal and seasonal variations of $\mathrm{NO}, \mathrm{NO}_{2}$, and $\mathrm{PM}_{2.5}$ as a function of traffic volumes. Such characterizations directly improve understanding of ambient surrogates of traffic for the U.S. urban arterial microenvironment. Characterization by time of day and seasons is important as epidemiological studies incorporate time activity patterns within cohort studies to understand exposure beyond annual mean concentrations ${ }^{51}$. The promotion of active transportation modes such as bicycling and walking also increases the need for understanding short-term concentrations to improve exposure evaluation for these travel modes ${ }^{52,53}$. Lastly, our analysis has implications for using traffic volumes as a proxy for transportation-related emissions. For example, land use regression (LUR) typically uses proximity to road type or traffic volumes to estimate exposure ${ }^{54}$. As LUR models are developed to predict more temporally resolved exposure estimates and health studies move towards shorter term exposure and impact assessments, the limitations of traffic 
volumes as a proxy highlighted here are important to note.

\subsection{Methods}

An air quality monitoring station was established at a high traffic intersection that includes a diverse mix of road users (including freight, public transit, pedestrians, cyclists and passenger vehicles) in Portland, Oregon USA (southwest corner of SE Powell

Boulevard and SE $26^{\text {th }}$ Avenue, (Figure 2.1). SE Powell Boulevard is a major arterial roadway that runs east/west with peak hourly traffic volumes of 2,800 vehicles and 28,000 Average Annual Daily Traffic (AADT), including 6\% trucks on weekdays. At the study intersection, SE Powell Blvd is a four lane undivided arterial with two vehicle lanes in each direction, left turn bays and auxiliary right turn lane in the eastbound direction. SE $26^{\text {th }}$ Avenue has one vehicle lane in each direction, left turn bays and a bike lane in each direction. SE Powell Boulevard runs a high frequency bus route and SE $26^{\text {th }}$ Avenue runs a typical bus route. 


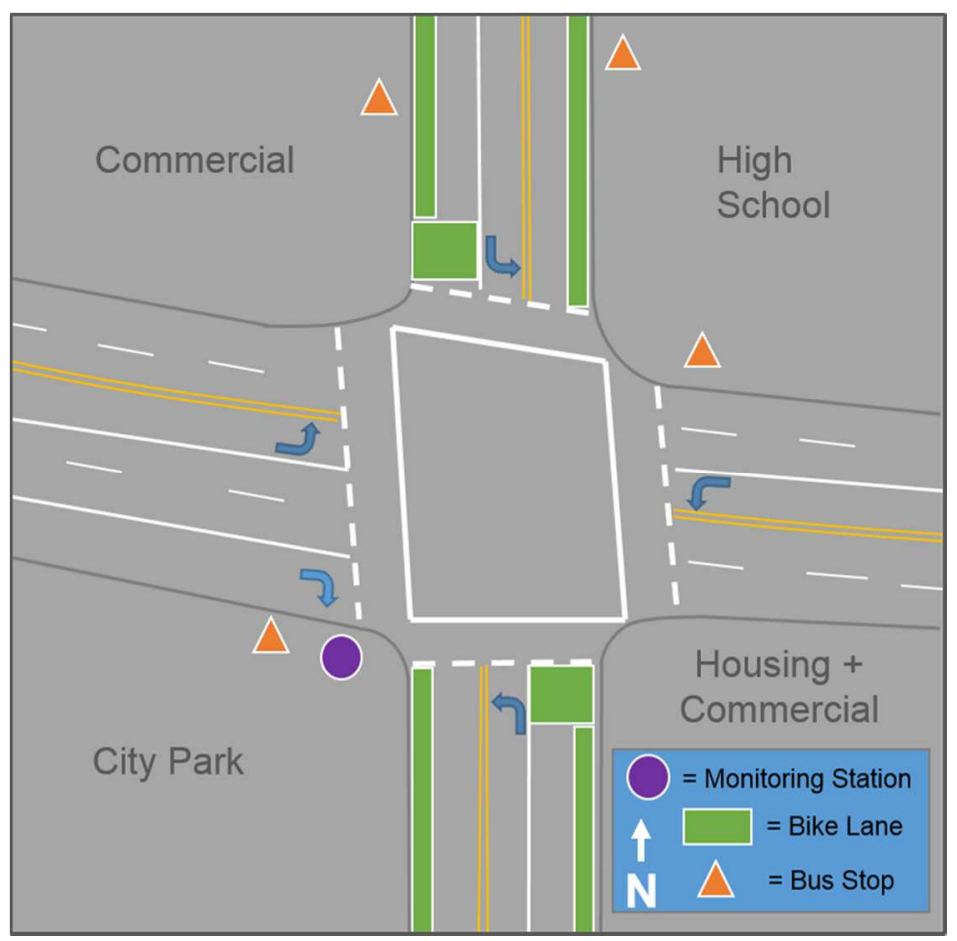

Figure 2.1 Schematic of study intersection. Air quality monitoring cabinet (purple circle) is located on the SW corner of Powell Blvd which runs E/W and SE 26th Ave runs N/S.

Diagonally across the intersection from the monitoring station is a high school that serves a population of 1,550 students and a staff of approximately 80 . Pedestrian activity is high through this intersection due to the school, nearby housing and apartments, a city park at the SW corner of the intersection, restaurants in the vicinity, and access to bus stops for major north-south and east-west bus routes. A snapshot traffic survey was conducted by the City of Portland for two hours in the morning and two hours in the evening on one day in February $2012^{55}$. This survey found morning pedestrian levels at 225 people over two hours (which included the school start) and the evening two hour period had a total of 157 pedestrians crossing, not including individuals waiting at bus stops. This same survey found a two hour morning bicycle count for all crossings to 
be 111 bikes and the evening period to contain 106 bikes. City bicycle data shows summer biking levels to range from 1.8-2.4 times higher than bike count levels for the month of February which is typically cold and wet in the Portland area ${ }^{56}$.

Traffic volumes in fifteen minute bins for each lane in the intersection were collected using inductive loop detectors and the Sydney Coordinated Adaptive Traffic System (SCATS) infrastructure. SCATS is an adaptive signal system that operates on a 3.7 mile stretch of Powell Blvd including the study intersection ${ }^{57}$. $\mathrm{NO}$ and $\mathrm{NO}_{2}$ were monitored using a Teledyne T200 chemiluminescence $\left(\mathrm{NOx}=\mathrm{NO}+\mathrm{NO}_{2}\right)$ analyzer and $\mathrm{PM}_{2.5}$ using a TSI DRX DustTrak monitor. Equipment is housed in a pole mounted traffic signal cabinet with a sampling inlet placed at $2.5 \mathrm{~m}$ above the sidewalk and connected to the inlet with non-reactive sampling lines. The height of the inlet ensures that intakes are out of reach of disturbance from the street (there being a heavily used bus stop at the corner) but still captures road emissions at the street level. Prior to installation, needed lengths of tubing for each instrument were tested to confirm that there was no significant loss in pollutants. Calibration of the NOx analyzer was performed throughout the study period using certified standard gases and calibration of the DustTrak was conducted through factory calibration with zero and flow checks performed on site, with zero checks performed approximately every 14 days.

Additional data collected at the intersection includes wind speed and direction (RM Young 3D Sonic Anemometers Model 81000) and temperature and relative humidity (RM Young Probe Model 41382VC). Wind data was supplemented with measurements from the Oregon Department of Environmental Quality's (DEQ) regional 
monitoring station. The DEQ site is located $3.4 \mathrm{~km}$ east of the roadside station and 0.09 km south of Powell Boulevard. Continuous air quality $\left(\mathrm{NO}, \mathrm{NO}_{2}, \mathrm{PM}_{2.5}\right)$ and meteorology data from this background station is collected, stored and accessed through the Portland Horizons database ${ }^{58}$. The DEQ site instruments and calibration procedures follow federal monitoring guidelines. All data referred to as "urban background" is from this DEQ station.

Data analysis presented here is based on one year of monitoring including a total of 362 days of NOx and 289 days of $\mathrm{PM}_{2.5}$ measurements at 30-second intervals (January 01, 2013- December 31, 2013). Total sampling points for $\mathrm{PM}_{2.5}$ were limited by flow and data storage issues as well as time off site for factory calibration. For quality assurance/quality control (QA/QC) reasons, measurements made outside of each instrument's operating temperature range based on continuous monitoring of the cabinet temperature were excluded from further analysis. Photometers such as the DustTrak can overestimate ambient particulate matter concentrations due to particle composition, density, morphology, and relative humidity (due to particle hygroscopicity). Therefore a correction factor of 0.5 was applied to the DustTrak measurements based on a comparison study in Portland between DustTrak and gravimetric measurements of ambient $\mathrm{PM}_{2.5}{ }^{59}$. Data presented is aggregated to 15 minutes to allow for direct comparisons with traffic volumes which are binned to 15 minutes. Analysis uses measurements only when the wind direction was coming from the road. This will be referred to as the road wind direction bin which includes $270^{\circ}(\mathrm{W})$ to $365^{\circ}(\mathrm{N})$ and $0^{\circ}(\mathrm{N})$ to $125^{\circ}(\mathrm{SE})$ in order to capture arterial traffic influences. Data analysis was conducted 
using R statistical language and the lattice and quantreg packages ${ }^{60-62}$.

\subsection{Results and Discussion}

\subsubsection{Traffic and Pollutant Relationships}

Mean, median, $5^{\text {th }}$ and $95^{\text {th }}$ percentile values of roadside $\mathrm{NO}, \mathrm{NO}_{2}, \mathrm{PM}_{2.5}$ and traffic volumes are presented in Table 2.1 to show distributions of measurements and compare to urban background concentrations. Data is separated by weekdays and weekends. For each pollutant, roadside measurements show elevated peak concentrations ( $95^{\text {th }}$ percentiles) compared to background levels, demonstrating an increase in measured pollutant levels for the roadside over urban background. Over the entire monitoring period, roadside weekday and weekend means are significantly greater than urban background means for all three pollutants using a data subset with no serial correlation, (t-values ranging from 4.4 to 32 , all p-values $<0.01$ ).

Roadside $\mathrm{NO}_{2}$ and $\mathrm{PM}_{2.5}$ show smaller differences from urban background levels than roadside $\mathrm{NO}$. This is not unexpected for $\mathrm{NO}_{2}$ since the rate of secondary formation of $\mathrm{NO}_{2}$ directly at the roadside would vary depending on mechanical turbulence, dispersion by wind, and existing concentrations of $\mathrm{NO}$, ozone $\left(\mathrm{O}_{3}\right.$, primary oxidant for $\mathrm{NO}$ to $\mathrm{NO}_{2}$ conversion) and other chemical species. Additionally, the urban background site is located within the $300 \mathrm{~m}$ buffer that $\mathrm{NO}$ and $\mathrm{NO}_{2}$ are typically elevated above background concentrations from the major road ${ }^{5}$. The average $\mathrm{NO} / \mathrm{NO}_{2}$ ratio for the urban background site is 0.7 while the average $\mathrm{NO} / \mathrm{NO}_{2}$ ratio at the roadside site is 1.6 
showing a higher proportion of $\mathrm{NO}$ or freshly emitted pollutants as expected directly at a roadside.

Mean weekday and weekend $\mathrm{PM}_{2.5}$ roadside concentrations were found to be statistically significant with roadside levels greater than background levels by a mean of the differences equal to only $2 \mu \mathrm{g} / \mathrm{m}^{3}$ (weekdays) and $1 \mu \mathrm{g} / \mathrm{m}^{3}$ (weekends). The DustTrak has a resolution of $1 \mu \mathrm{g} / \mathrm{m}^{3}$ so the statistically significant difference is just above or at instrument resolution. Weekend mean and $95^{\text {th }}$ percentile $\mathrm{PM}_{2.5}$ concentration for both the roadside and urban background site are slightly higher than weekdays despite higher traffic volumes on weekdays. Table 2.1 does not show a strong local relationship for roadside $\mathrm{PM}_{2.5}$ measurements compared to urban background.

Table 2.1 Roadside and urban background comparisons for weekdays and weekends, spanning Jan 2013- Dec 2013 at 15 minute aggregations

\begin{tabular}{|c|c|c|c|c|}
\hline \multirow[b]{2}{*}{ Pollutant } & \multicolumn{2}{|c|}{ Weekdays } & \multicolumn{2}{|c|}{ Weekends } \\
\hline & $\begin{array}{c}\text { Roadside } \\
\text { Mean } \\
\text { Median } \\
\text { (5 } 5^{\text {th }}-95^{\text {th }} \text { Percentiles) }\end{array}$ & $\begin{array}{c}\text { Urban Background } \\
\text { Mean } \\
\text { Median } \\
\left.\text { (5 } 5^{\text {th }}-95^{\text {th }} \text { Percentiles }\right)\end{array}$ & $\begin{array}{c}\text { Roadside } \\
\text { Mean } \\
\text { Median } \\
\text { (5 } 5^{\text {th }}-95^{\text {th }} \text { Percentiles) }\end{array}$ & $\begin{array}{l}\text { Urban Background } \\
\text { Mean } \\
\text { Median } \\
\text { (5 } 5^{\text {th }}-95^{\text {th }} \text { Percentiles) }\end{array}$ \\
\hline NO (ppb) & $\begin{array}{c}28 \\
20 \\
(1.3-79)\end{array}$ & $\begin{array}{c}9 \\
2 \\
(0.4-45)\end{array}$ & $\begin{array}{c}18 \\
10 \\
(1-59)\end{array}$ & $\begin{array}{c}8 \\
2 \\
(0.4-38)\end{array}$ \\
\hline $\mathrm{NO}_{2}$ (ppb) & $\begin{array}{c}16 \\
15 \\
(5-31)\end{array}$ & $\begin{array}{c}11 \\
9 \\
(3-24)\end{array}$ & $\begin{array}{c}11 \\
10 \\
(4-23)\end{array}$ & $\begin{array}{c}9 \\
7 \\
(2-22)\end{array}$ \\
\hline $\mathrm{PM}_{2.5}\left(\mu \mathrm{g} / \mathrm{m}^{3}\right)$ & $\begin{array}{c}9 \\
6 \\
(0-28)\end{array}$ & $\begin{array}{c}7 \\
5 \\
(2-20)\end{array}$ & $\begin{array}{c}10 \\
5 \\
(0-32)\end{array}$ & $\begin{array}{c}8 \\
5 \\
(2-22)\end{array}$ \\
\hline $\begin{array}{l}\text { Traffic Volumes/ } \\
15 \text { mins }\end{array}$ & $\begin{array}{c}493 \\
554 \\
(65-888)\end{array}$ & & $\begin{array}{c}395 \\
407 \\
(74-735)\end{array}$ & \\
\hline
\end{tabular}


To further investigate the impact of the roadway, the relationship of each pollutant versus traffic volumes for all weekdays and road wind direction bin is shown in Figure 2.1. The rest of the data analysis presented will focus on weekdays only when traffic volumes and exposure concentrations are highest and also because weekends show separate diurnal patterns. The median relationship between each pollutant concentration and vehicle volumes binned by fifty is highlighted by white triangles in Figure 2.1. These relationships show increasing $\mathrm{NO}$ and $\mathrm{NO}_{2}$ with increasing traffic volumes and little change in $\mathrm{PM}_{2.5}$ mass as a function of traffic at the intersection. Roadside $\mathrm{NO}$ and $\mathrm{NO}_{2}$ are markers of the increased emissions due to the roadways while roadside $\mathrm{PM}_{2.5}$ mass is not responsive to local traffic volumes. For all three pollutants, variance is high as highlighted in Figure 2.1. How this variability changes by season and time of day is investigated next using seasonal and diurnal characterizations.
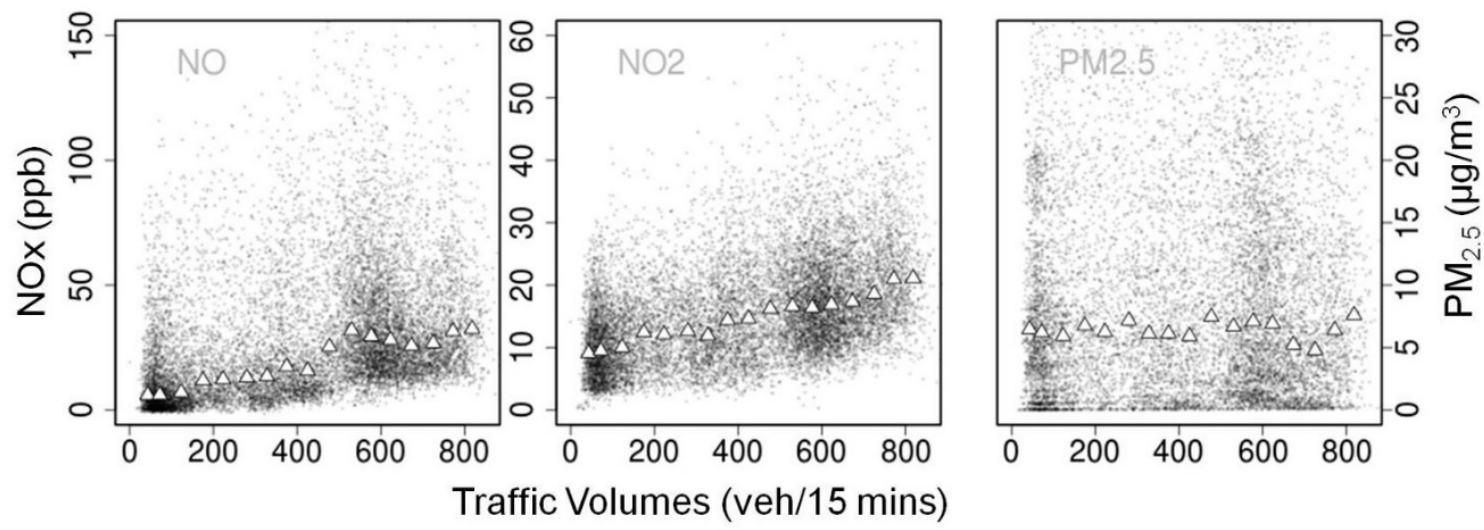

Figure 2.2 All weekday roadside pollutant measurements versus traffic volumes. White triangles show the median relationship of each pollutant with traffic volume bins of fifty. 


\subsubsection{Weekday, Seasonal and Diurnal Characterization of Roadside Pollutant}

Concentrations

Seasonal trends and diurnal patterns of traffic volumes and roadside pollutant measurements are presented in Figure 2.3 with black lines representing the $5^{\text {th }}$ and $95^{\text {th }}$ percentiles, and the colored line is the median. Total traffic volumes and peak morning and evening traffic volumes do not change much seasonally for the study intersection (Figure 2.3a). Daily peak and median concentrations for all three pollutants are greatest in the fall and winter and variability is greatest for these seasons as well (Figure 2.3b, c, d). These higher peak concentrations, elevated median levels, and overall greater concentrations ranges for all three pollutants in fall and winter reflect the lower boundary conditions and lower wind speeds (Figure 2.3e) leading to less dispersion for these seasons. These meteorological conditions allow for the maximum in $\mathrm{NO}, \mathrm{NO}_{2}$, and $\mathrm{PM}_{2.5}$ concentrations to vary more leading to increased variability overall for fall and winter. $\mathrm{PM}_{2.5}$ concentrations are also higher in fall and winter due to higher relative humidity conditions. Roadside measurements clearly show the potential for higher peak exposures to occur in the fall and winter for urban residents. 

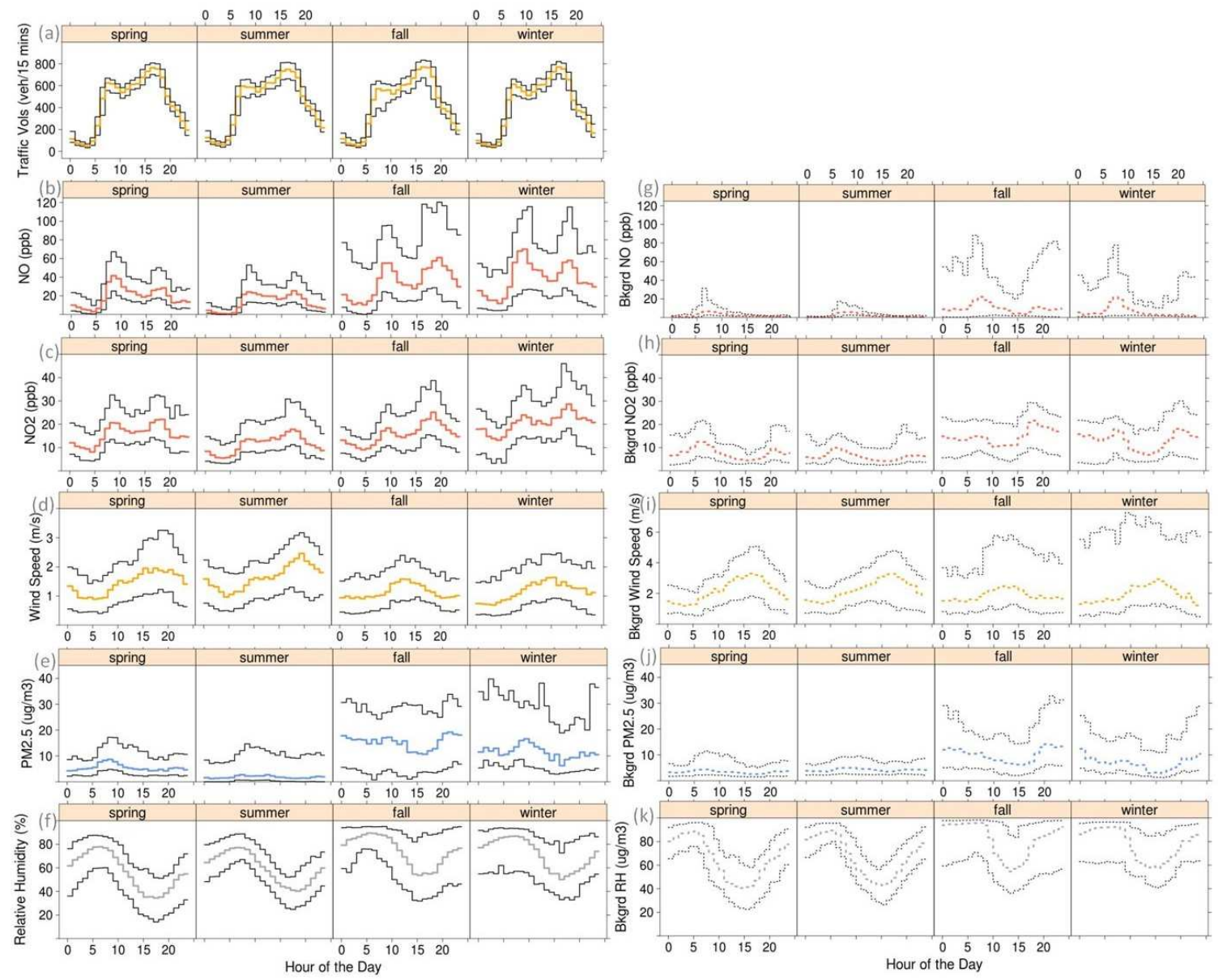

Figure 2.3 Weekday, seasonal diurnal distributions for (a) traffic volumes, (b-f) roadside $\mathrm{NO}, \mathrm{NO}_{2}$, wind speed, $\mathrm{PM}_{2.5}$, and relative humidity, and $(\mathrm{g}-\mathrm{k})$ urban background $\mathrm{NO}$, $\mathrm{NO}_{2}$, wind speed, $\mathrm{PM}_{2.5}$, and relative humidity. Colored lines represent the $50^{\text {th }}$ percentile and the black lines are the $10^{\text {th }}$ and $90^{\text {th }}$ percentile.

\subsubsection{Diurnal $\mathrm{NO}$ and $\mathrm{NO}_{2}$}

Roadside $\mathrm{NO}$ and $\mathrm{NO}_{2}$ have a bi-modal diurnal distribution for weekdays reflecting the morning and evening rush hours (Figure $2.3 \mathrm{a}, \mathrm{b}, \mathrm{c}$ ). The $\mathrm{NO}$ and $\mathrm{NO}_{2}$ bimodal pattern shows a seasonal trend. The evening peaks of $\mathrm{NO}$ and $\mathrm{NO}_{2}$ are more pronounced in fall and winter. The fall/winter and spring/summer differences in bi-modal distributions can be attributed to seasonal boundary layer height conditions and 
subsequent lower median wind speeds in fall and winter, and a change in the diurnal wind pattern by season (Figure 2.3d). As the height of the boundary layer increases in spring and summer, wind speed increases at a faster rate throughout the day, increasing dispersion. Urban background $\mathrm{NO}$ and $\mathrm{NO}_{2}$ (Figure $2.3 \mathrm{~g}$ and $\mathrm{h}$ ) show similar seasonal trends with higher concentrations in fall and winter and a more dominant peak in morning with little to no evening peak in spring and summer.

The diurnal trends documented in other roadside monitoring studies are attributed to a combination of meteorology and changing traffic volumes throughout the year or measurements occur over a small segment of the year so the seasonal variation in diurnal trends is not captured. Summertime roadside measurements made in Raleigh, North Carolina near a highway showed only a morning peak in traffic-related pollutants (NO and $\mathrm{CO}$ ) attributed to highly variable winds ${ }^{63,64}$. Springtime urban arterial roadside measurements made in Copenhagen, Denmark showed two peaks for NOx, but the afternoon peak was much less distinct and attributed to lower afternoon traffic volumes 65. Urban arterial roadside measurements made in Athens, Greece over several years showed seasonal, diurnal variation in roadside NO with the highest evening peak occurring in winter attributed to a combination of stable atmospheric conditions and higher traffic volumes compared to other months ${ }^{31}$. Conversely, Mavroidis and Ilia (2012) showed very little differences in $\mathrm{NO}_{2}$ diurnal trends across seasons with winter concentrations being the lowest.

In contrast, we show distinct seasonal, diurnal differences that are due primarily to meteorology as the diurnal traffic volumes for this study road are uniform throughout 
the whole year and data presented is for wind directions coming from the road only. The influence of boundary layer height and meteorology is supported by the urban background concentration trends and roadside measurements showing the distinct bimodal pattern following local traffic volumes for fall and winter. We also show a strong boundary layer height effect on $\mathrm{NO}_{2}$ with highest concentrations in winter despite the lower presence of oxidants and less photolysis. Urban background $\mathrm{NO}_{2}$ concentrations show this same seasonal pattern. Traffic simulation and emissions modeling for planning and new transportation projects typically use evening peak traffic volumes. Usually these models have a target of estimating maximum emission levels; evening peak traffic volumes tend to be greater than morning levels. However, if a transportation project requires estimates of peak pollutant concentrations and not just peak emissions, the results presented here show that morning periods are also important. The morning period could be used as a more consistent input across seasons for exposure concentration estimates depending on the objective of the modeling or exposure assessment project.

\subsubsection{Diurnal $\mathrm{PM}_{2.5}$}

$\mathrm{PM}_{2.5}$ concentrations do not show a bi-modal distribution correlated with traffic (Figure 2.3e). The lack of this pattern in seasonal, diurnal $\mathrm{PM}_{2.5}$ distributions is consistent with the lack of a strong relationship between local traffic volumes and roadside $\mathrm{PM}_{2.5}$ mass. An increase in the morning can be seen for spring and winter. The median morning increase is $4 \mu \mathrm{g} / \mathrm{m}^{3}$ for spring occurring between $8-9$ am and $6 \mu \mathrm{g} / \mathrm{m}^{3}$ for winter occurring between 9-10am. These morning increases show some response to increasing traffic volumes, but the response is not consistent throughout the year. Morning $\mathrm{PM}_{2.5}$ peaks 
have been found to occur slightly later than the traffic peak due to the secondary formation of fine particulate matter ${ }^{66}$. Concentrations are highest in fall and winter for both roadside and urban background $\mathrm{PM}_{2.5}$ (Figure 2.3j). The diurnal pattern for these seasons is dominated by high relative humidity reflected by the elevated $\mathrm{PM}_{2.5}$ levels in early morning and nighttime which follow the seasonal, diurnal relative humidity distributions (Figure $2.3 \mathrm{f}$ and $\mathrm{k}$ ). The cooler temperatures and higher relative humidity increase condensation and coagulation leading to increased $\mathrm{PM}_{2.5}{ }^{67}$. Annual and seasonal, diurnal distributions for measured $\mathrm{PM}_{2.5}$ do not consistently reflect the local traffic volumes well and are most characteristic of meteorological conditions such as relative humidity and boundary layer height increasing concentrations ranges for winter and fall which are also reflected in the urban background $\mathrm{PM}_{2.5}$ concentrations.

Particulate matter is a component of traffic-related emissions but PM mass measurements do not always capture this influence. A meta-analysis conducted by Karner et al (2010) based on over fifteen studies with $\mathrm{PM}_{2.5}$ measurements around roadways found mixed results regarding the spatial distribution of fine particles. Using a background normalization method, $\mathrm{PM}_{2.5}$ was found to have no trend around roadways so was not elevated at the roadside compared to background. However, using an edge of the roadway normalization method, $\mathrm{PM}_{2.5}$ was found to have a gradual decay away from roads. For an area such as Portland, OR that does not have as much diesel traffic as a freeway in California or a European roadway, the increase in $\mathrm{PM}_{2.5}$ mass directly from transportation-related emissions may be too small of a signal above the noise and secondary formation of urban background pollution. 
Particles in the $\mathrm{PM}_{2.5}$ range have a variety of anthropogenic sources in an urban area including other primary combustion sources (industry, large-scale cooking, liquid and solid fuel heating), other non-road sources (construction equipment, railways), and secondary formation via gas to particle conversions, coagulation and condensation of smaller particles ${ }^{68}$. These sources and processes lead to a more spatially homogenous pattern of $\mathrm{PM}_{2.5}$ mass. While $\mathrm{PM}_{2.5}$ mass does not always show the impact of local traffic emissions, other measurements of PM can. Particle composition has been shown to vary spatially near roadways while $\mathrm{PM}_{2.5}$ mass had low spatial variation ${ }^{69}$. In a review of indoor, outdoor, and personal exposure to $\mathrm{PM}, \mathrm{PM}_{2.5}$ spatial variation was found to be much smaller compared to particle number concentrations (PNC) and larger size fractions 68. Our results and the variability in $\mathrm{PM}_{2.5}$ mass responses to traffic across studies suggests that measurements of $\mathrm{PM}_{2.5}$ mass as a proxy to assess the impact of roadway pollution may need location-specific validation.

\subsubsection{Estimating Roadside NOx as a Function of Traffic Volumes}

Measured roadside $\mathrm{NO}$ and $\mathrm{NO}_{2}$ is responsive to local traffic volumes, but with distinct seasonal and diurnal trends on the fifteen minute time scale. If traffic volumes are used as a proxy in exposure assessment focused on shorter time scales such as the time a pedestrian or bicyclist spends in the roadside microenvironment, traffic volumes alone may not correlate with roadside exposure concentrations. Quantile regression for the median is used to assess roadside NOx as a function of traffic volumes for short-term aggregations (15 minutes) for morning periods (5-10am) and evening periods (3-8pm) for each season. Time periods were chosen based on the previous diurnal analysis, 
systematically controlling for diurnal meteorological changes and capturing different traffic flow regimes which encompass the morning and evening peaks in traffic volumes. In order to get rid of serial correlation, three data points were randomly sampled from each time period per day. At a random sample of three points per period per day, autocorrelation is reduced for $\mathrm{NO}, \mathrm{NO}_{2}$, and traffic volumes and the total number of sample points used to build the models is reduced from 13,739 to 1,197 . This method ensures no serial correlation while still allowing high resolution measurements at 15 minute aggregations to be used. Figure 2.4 shows the median regression relationships of roadside $\mathrm{NO}_{2}$ as a function of traffic volumes for morning and evening periods for each season. Table 2.2 shows the following values for $\mathrm{NO}$ and $\mathrm{NO}_{2}$ models built using both the randomly selected data subset and all data which is serially correlated: model coefficients per 100 vehicles in a 15 minute period, standard errors for the coefficients per 100 vehicles, and $\mathrm{r}^{2}$ values. Quantile regression was used because of the right skewed nature of the data and quantile regression can capture when a change in your independent variable exerts both a change in mean and variance in your dependent variable so heteroskedasticity is not a major concern ${ }^{70}$. 

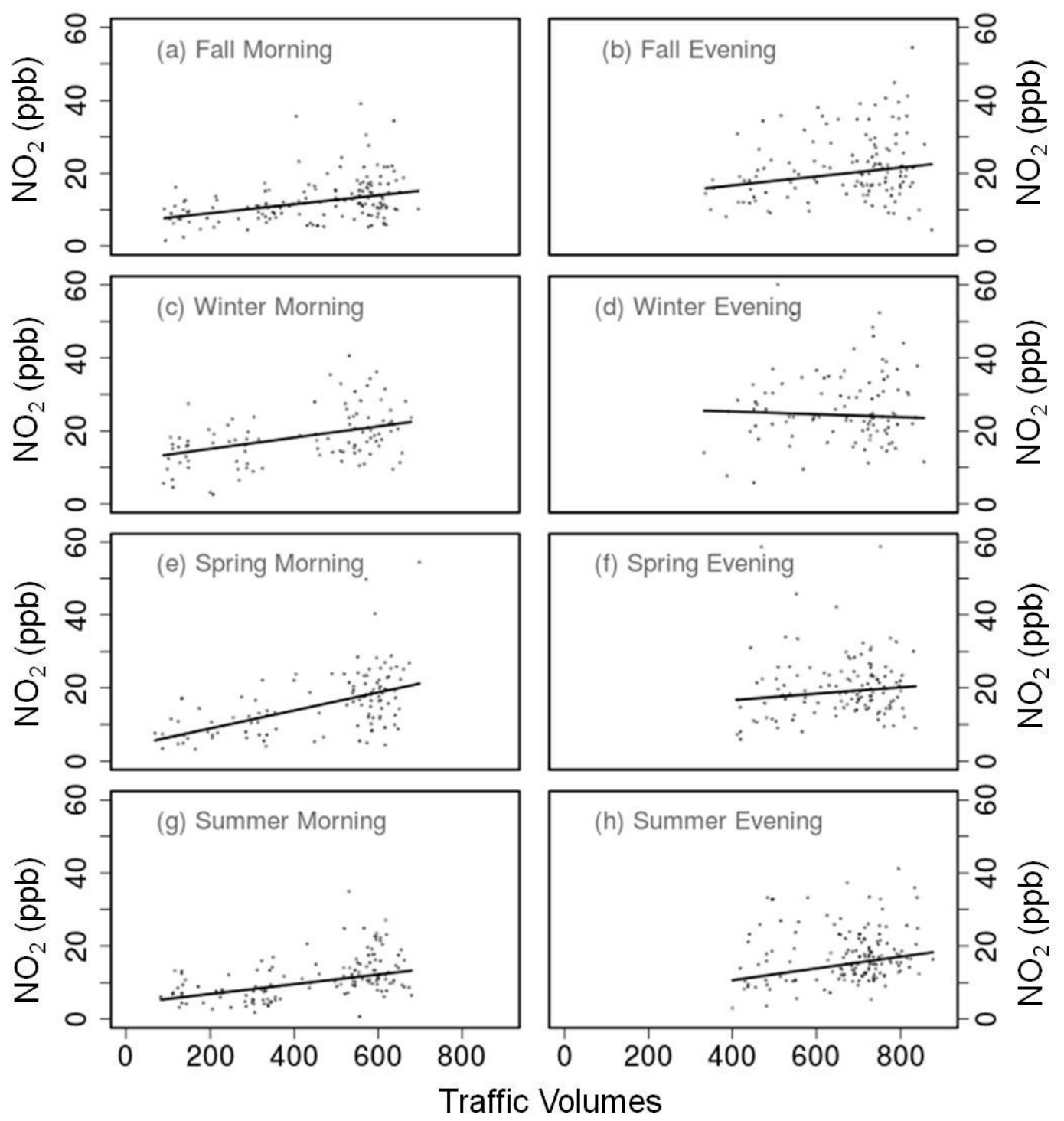

Figure 2.4 Median regression relationships of traffic volumes and roadside $\mathrm{NO}_{2}$ given season and morning and evening peak periods. 
Table 2.2 Median regression slope coefficients, standard errors and $\mathrm{r}^{2}$ values for roadside NOx as a function of traffic volumes using randomly sampled subset (black) and all serially correlated data points (grey). ${ }^{* *}$ significance at $<0.01$ and $*$ significance at $<0.05$

\begin{tabular}{|c|c|c|c|c|c|c|c|}
\hline Season & $\begin{array}{l}\text { Time } \\
\text { Period }\end{array}$ & $\begin{array}{c}\text { Coefficient NO } \\
\text { per } 100 \text { vehicles } \\
\text { per } 15 \text { mins }\end{array}$ & $\begin{array}{l}\text { Standard Error } \\
\text { of Coefficient NO } \\
\text { per } 100 \text { vehicles } \\
\text { per } 15 \text { mins }\end{array}$ & $\begin{array}{c}\text { Adjusted } \\
\mathrm{r}^{2} \\
\end{array}$ & $\begin{array}{c}\text { Coefficient } \mathrm{NO}_{2} \\
\text { per } 100 \text { vehicles } \\
\text { per } 15 \text { mins }\end{array}$ & $\begin{array}{c}\text { Standard Error } \\
\text { of Coefficient } \mathrm{NO}_{2} \\
\text { per } 100 \text { vehicle } \\
\text { per } 15 \text { mins }\end{array}$ & $\begin{array}{c}\text { Adjusted } \\
\mathbf{r}^{2}\end{array}$ \\
\hline Fall & Morning & $\begin{array}{l}6.3^{* *} \\
(7.9)^{* *}\end{array}$ & $\begin{array}{c}1.4 \\
(0.4)\end{array}$ & $\begin{array}{c}0.1 \\
(0.16)\end{array}$ & $\begin{array}{l}1.2^{\star \star} \\
(1.6)^{\star \star \star}\end{array}$ & $\begin{array}{c}0.2 \\
(0.1)\end{array}$ & $\begin{array}{c}0.14 \\
(0.24)\end{array}$ \\
\hline Winter & Morning & $\begin{array}{c}9.4^{\star *} \\
(11.2)^{\star \star *}\end{array}$ & $\begin{array}{c}1.4 \\
(0.7)\end{array}$ & $\begin{array}{c}0.14 \\
(0.24)\end{array}$ & $\begin{array}{l}1.5^{\star \star} \\
(1.9)^{\star \star}\end{array}$ & $\begin{array}{c}0.4 \\
(0.2)\end{array}$ & $\begin{array}{c}0.17 \\
(0.26)\end{array}$ \\
\hline Spring & Morning & $\begin{array}{l}6.3^{* *} \\
(6.7)^{* *}\end{array}$ & $\begin{array}{l}0.8 \\
(0.3)\end{array}$ & $\begin{array}{c}0.41 \\
(0.43)\end{array}$ & $\begin{array}{l}2.5^{\star \star} \\
(2.3)^{* \star}\end{array}$ & $\begin{array}{c}0.3 \\
(0.2)\end{array}$ & $\begin{array}{c}0.27 \\
(0.28)\end{array}$ \\
\hline Summer & Morning & $\begin{array}{c}4.6^{\star \star} \\
(4.4)^{* \star}\end{array}$ & $\begin{array}{l}(0.4) \\
(0.2)\end{array}$ & $\begin{array}{l}(0.45) \\
(0.37)\end{array}$ & $\begin{array}{l}1.3^{\star \star *} \\
(1.6)^{\star \star *}\end{array}$ & $\begin{array}{c}0.3 \\
(0.1)\end{array}$ & $\begin{array}{c}0.25 \\
(0.23)\end{array}$ \\
\hline Fall & Evening & $\begin{array}{l}-1.3 \\
(-1.6)\end{array}$ & $\begin{array}{c}2.5 \\
(1.1)\end{array}$ & $\begin{array}{l}<0.001 \\
(0.005)\end{array}$ & $\begin{array}{l}1.2^{*} \\
(0.9)\end{array}$ & $\begin{array}{c}0.6 \\
(0.2)\end{array}$ & $\begin{array}{c}0.05 \\
(0.03)\end{array}$ \\
\hline Winter & Evening & $\begin{array}{l}-0.04 \\
(0.09)\end{array}$ & $\begin{array}{c}2.6 \\
(1.3)\end{array}$ & $\begin{array}{c}0.002 \\
(0.001)\end{array}$ & $\begin{array}{c}-0.4 \\
(-0.08)\end{array}$ & $\begin{array}{c}0.8 \\
(0.4)\end{array}$ & $\begin{array}{c}0.05 \\
(0.03)\end{array}$ \\
\hline Spring & Evening & $\begin{array}{c}2.1 \\
(2.2)^{* *}\end{array}$ & $\begin{array}{c}1.1 \\
(0.5)\end{array}$ & $\begin{array}{c}0.03 \\
(0.04)\end{array}$ & $\begin{array}{c}0.9 \\
(0.9)^{* *}\end{array}$ & $\begin{array}{l}(0.8) \\
(0.3)\end{array}$ & $\begin{array}{l}0.007 \\
(0.02)\end{array}$ \\
\hline Summer & Evening & $\begin{array}{l}2.1^{*} \\
(2.9)^{* *}\end{array}$ & $\begin{array}{c}0.8 \\
(0.3)\end{array}$ & $\begin{array}{c}0.02 \\
(0.07)\end{array}$ & $\begin{array}{c}1.6^{*} \\
(1.9)^{* * *}\end{array}$ & $\begin{array}{c}0.7 \\
(0.2)\end{array}$ & $\begin{array}{c}0.03 \\
(0.05)\end{array}$ \\
\hline
\end{tabular}

The standard errors and coefficient estimates in Table 2.2 overlap between each model built using the randomly sampled subset and each model built using all data with serial correlation. These results demonstrate that randomly selecting points within our time periods and seasons to remove any serial correlation maintains the relationships found using all data. Morning periods for all four seasons show a significant linear relationship ( $\mathrm{p}$-values $<0.01$ ) between traffic volumes and $\mathrm{NO}$ and $\mathrm{NO}_{2}$. Boundary layer height is low in the morning for all four seasons creating similar meteorological conditions. As traffic volumes increase throughout the morning and boundary layer height increases as well, a positive linear relationship is seen for traffic volumes and NO and $\mathrm{NO}_{2}$ on a fifteen minute scale. As meteorology introduces higher variability in the evening due to a changing boundary layer and more variable winds, the linear 
relationship of traffic volumes explains little to none of the variance in roadside 15 minute median NOx for this later time period $\left(\mathrm{r}^{2}\right.$ range from $<0.001$ to 0.05$)$.

A linear relationship between NOx and traffic volumes was found for free-flow conditions only based on one month of roadside pollutant and hourly traffic measurements in Leicester, $\mathrm{UK}^{71}$. The linear relationship broke down during unstable and congested traffic flow conditions with occupancy $>10 \%{ }^{71}$. Results presented here show that the linear relationship even at short-term aggregations holds true past free-flow conditions and throughout the congested morning traffic period. We attribute the breakdown in the linear relationship to changing meteorological and dispersion conditions.

While the short-term NOx and traffic volume models were significant for all morning periods, variance explained ranges from 0.1 to 0.45 . Figure 2.5 shows the relationship of traffic volumes and $\mathrm{NO}_{2}$ for morning and evening periods at a coarser aggregation using traffic volume bins of 50 vehicles and data across the entire year. Table 2.3 shows the annual regression values for $\mathrm{NO}$ and $\mathrm{NO}_{2}$. There is still no significant effect of traffic volumes on annual NO for the evening period. Using binned annual data, the coefficient of determination $\left(\mathrm{r}^{2}\right)$ values for $\mathrm{NO}$ and $\mathrm{NO}_{2}$ as a function of traffic volumes are 0.89 ( $\mathrm{NO}$ morning), 0.87 ( $\mathrm{NO}_{2}$ morning) and $0.46\left(\mathrm{NO}_{2}\right.$ evening). Summarized over one year, the seasonal and some meteorological variability are averaged out and traffic volumes are a better predictor of roadside NOx. Even at a larger aggregation, the evening time period is still more variable compared to mornings. 


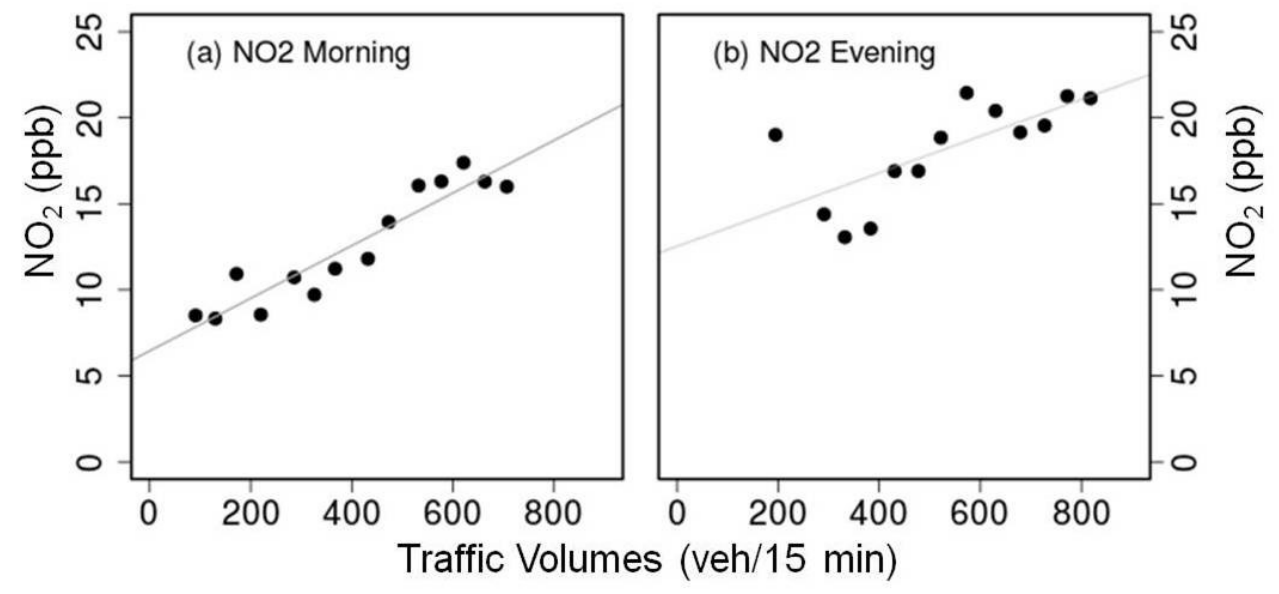

Figure 2.5 Median roadside $\mathrm{NO}_{2}$ as a function of traffic volumes binned by 50 vehicles across the entire year.

Table 2.3 Regression results for median annual $\mathrm{NO}$ and $\mathrm{NO}_{2}$ as a function of traffic volumes

\begin{tabular}{|l|l|c|c|c|c|c|c|}
\hline & $\begin{array}{c}\text { Time } \\
\text { Period }\end{array}$ & $\begin{array}{c}\text { Coefficient NO } \\
\text { per } 100 \text { vehicles } \\
\text { per 15 mins }\end{array}$ & $\begin{array}{c}\text { Standard Error } \\
\text { of Coefficient NO } \\
\text { per } 100 \text { vehicles } \\
\text { per 15 mins }\end{array}$ & $\begin{array}{c}\text { Adjusted } \\
r^{2}\end{array}$ & $\begin{array}{c}\text { Coefficient NO } \\
\text { per } 100 \text { vehicles } \\
\text { per 15 mins }\end{array}$ & $\begin{array}{c}\text { Standard Error } \\
\text { of Coefficient } \mathrm{NO}_{2} \\
\text { per 100 vehicle } \\
\text { per 15 mins }\end{array}$ & $\begin{array}{c}\text { Adjusted } \\
r^{2}\end{array}$ \\
\hline Annual & Morning & $6.3^{* *}$ & 0.6 & 0.89 & $1.5^{* *}$ & 0.2 & 0.87 \\
\hline Annual & Evening & -0.2 & 1.4 & -0.09 & $1.1^{* *}$ & 0.3 & 0.46 \\
\hline
\end{tabular}

\subsection{Conclusion}

In this study, we characterized the pollutant levels in an urban arterial roadside environment in a mid-sized U.S. city over the course of a year. Urban arterial roadside environments are under-sampled in the U.S. but have potential to produce high exposures due to the mix of road users and close proximity of urban residents. Roadside monitoring for a variety of roadway types including arterials is well established in European countries, though with different fleet mixes, fuel, vehicle and air quality standards. Such research has helped document long-term trends and important characteristics of traffic- 
related pollutants but has not focused on analysis of short-term changes as a function of traffic volume, time of day, and season ${ }^{31,72,73}$. Here we extend the understanding of temporal variability of $\mathrm{NO}$ and $\mathrm{NO}_{2}$ by showing how the relationships with traffic volumes change temporally and we provide model coefficients (Table 2.3) that are applicable to exposure assessment in North America.

Direct evaluations with local traffic volumes showed $\mathrm{NO}$ and $\mathrm{NO}_{2}$ are significantly affected by traffic volumes and $\mathrm{PM}_{2.5}$ mass is not responsive to traffic volumes at this study intersection. $\mathrm{PM}_{2.5}$ mass for this urban arterial appears to be more tied to regional sources. Seasonal and diurnal characterization of $\mathrm{NO}$ and $\mathrm{NO}_{2}$ showed morning peaks to be consistent throughout all seasons, while a bi-modal distribution with both a morning and evening peak was most prominent in fall and winter. The consistent diurnal traffic volume trends allowed for the large impact of seasonal boundary conditions to be evident. Highest exposures would occur in fall and winter when stable boundary layer conditions reduce dilution.

Our study shows the limitations of using traffic volumes alone as a proxy for traffic-related emissions. During the evening time period in all seasons, there was little to no relationship of traffic volumes and roadside NOx using quantile regression modeling at 15 minute aggregations. While there was a significant relationship of traffic volumes and NOx for all morning periods, variability of roadside NOx as a function of traffic volumes was still high. On an annual timescale and aggregated by traffic volume bins, the variability in roadside $\mathrm{NO}$ and $\mathrm{NO}_{2}$ due to seasonality and meteorology is reduced and traffic volumes alone are a better predictor of roadside concentrations, demonstrating 
this method can capture chronic but not acute exposure. However, even at this coarser temporal scale, the relationship between traffic volumes and $\mathrm{NO}$ and $\mathrm{NO}_{2}$ levels during evening periods is not consistent. Other analyses using long-term urban background and some roadside monitoring data have noted that daily averaged data in exposure studies could potentially miss very different patterns of exposure ${ }^{73}$. As exposure science moves to capture more short-term patterns of exposure and account for time spent in traffic for various travel modes, traffic volumes will need to be used along with local and meteorological effects in order to best represent the high variability in roadside pollutant concentrations, especially for evening periods.

Our findings that roadside $\mathrm{PM}_{2.5}$ mass is non-responsive to local traffic volumes supports the idea that other measures of particulate matter may be needed to capture the increased health risk due to primary combustion particles. This is an important consideration as the U.S. EPA adds PM mass measurements to the new roadway monitoring network. Identification of the type of environments that are more locally or regionally dominated by $\mathrm{PM}_{2.5}$ mass could help pinpoint the type of monitoring needed to accurately assess exposure to particulates due to traffic-related emissions. Emissions and dispersion models for the study intersection will be run in the future to allow for comparisons of measured concentrations and model outputs. If modeled $\mathrm{PM}_{2.5}$ mass concentrations are strongly tied to local traffic parameters, the models may be missing important processes related to urban particulate matter formation. 
Chapter 3 Assessing the effects of a reduced traffic signal cycle length on roadside NOx through the use of matched sampling

Abstract

Empirical evaluations and quantification of the relationships between a change in traffic management and traffic-related pollutant concentrations are needed to evaluate how well manipulations to traffic signal operations work as a mitigation tool. Assessing these effects using observational data has many challenges such as variability in covariates, non-randomized study design, temporal autocorrelation, and lack of control case studies for comparison. The study presented here assesses the effect of a reduced maximum cycle length on traffic flow through measurements of degree of saturation (DS), nitric oxide (NO) and nitrogen dioxide $\left(\mathrm{NO}_{2}\right)$. In order to reduce bias from covariates and assess the effect due to the change in cycle length only, a matched sampling method based on propensity scores is used to compare treatment periods (reduced cycle length) with control periods (no change in cycle length). The effect of this change is tested for the peak traffic periods of two separate case studies. The case studies are from a signalized intersection on an urban arterial in Portland, OR operated by an adaptive traffic signal system. The study intersection also contains a continuous air quality monitoring station. After applying the matched sampling and a random sampling method to control for covariates and temporal autocorrelation, case study 1 evening periods showed a significant increase in DS values for the main arterial in both directions (increase of 7\% and 8\%) resulting in a 5ppb increase in roadside NO. Case study 2 evening periods showed a range of 2-6\% increase in DS values for various approaches and an increase of 5-8ppb $\mathrm{NO}$ and 4-5ppb in $\mathrm{NO}_{2}$. All other periods evaluated showed no 
significant difference in DS values and no significant difference in NOx. This lack of an effect on DS is attributed to the fact that the cross-street in this study intersection carries approximately $20 \%$ of the traffic volumes of the major arterial. The results here demonstrate that a change in traffic flow and change in emissions can be measured through roadside pollutant concentrations. In order to further evaluate the variance in average treatment effect size of a reduction in cycle length on traffic flow and near-road pollution, these measurement and analysis methods should be applied to a larger intersection where the effect on traffic flow will be more present and consistent. Without matched and random sampling to address the challenges of observational data, the small changes in DS and NOx for the study intersection would have been masked and it is demonstrated that matched sampling is a helpful tool for future urban air quality empirical investigations.

\subsection{Introduction}

Improving traffic flow and reducing congestion to meet air quality standards and transportation conformity are common paths transportation planners take when deciding on transportation control measures (TCMs) and designing transportation improvement programs (TIPs) ${ }^{74}$. Emission effects due to changes in traffic signal variables are typically modeled using a combination of statistical modeling, traffic simulations and emissions models ${ }^{27,75-80}$. Simulation modeling is advantageous to test a number of scenarios and explore changes to traffic signal settings. However, it is rare for such evaluations to incorporate dispersion modeling or measurements after traffic and 
emissions simulations in order to understand changes in air pollutant concentrations and not only total emissions ${ }^{81}$. Empirical investigation of the effectiveness of signal timing as a TCM and improved understanding of the real-world relationship of varying traffic dynamics on pollutant concentrations, not just total emissions, is needed ${ }^{25}$.

On-road emissions measurements have been used as one technique to confirm claims of emissions reductions with traffic signal improvements ${ }^{25,82-84}$. Through measurements along signalized arterials, Unal et al (2003) demonstrated an association between reduced emissions and coordinated signal timing that reduced travel times and improved level of service (LOS). To make this comparison, simplified models that assumed the same modal emission rates before and after the signal coordination were used in order to control for variability from uncontrollable changes in ambient and vehicle conditions ${ }^{25,85}$. Unal et al. (2003) also noted that strategies reducing only stop time and not the total number of stops along an arterial may not be as effective in reducing total emissions because the highest emission rates were associated with acceleration and the lowest rates with idling.

Mobile emissions measurements made during uncongested periods through a roundabout and signalized intersection along a corridor in Minnesota, showed that roundabouts did not necessarily produce lower emissions than the signalized intersection because all vehicles have to slow for the roundabout while some test runs through the signal included no stopping at all for the vehicles ${ }^{83}$. However, emissions results were highly dependent on driving behavior. Kim et al. (2014) used mobile monitoring to assess the NOx profile around signalized intersections and found that intersections create a zone 
of enhanced pollution over a distance of approximately $\pm 100 \mathrm{~m}^{84}$. NOx concentrations also increased as the study vehicle stopped at increased distances from the intersection stop line due to longer queues during a red light. These increases in NOx were attributed to the acceleration of more vehicles ahead of the study vehicle. This work only briefly considered the effects of wind speed and direction and did not take into account surrounding traffic volumes in opposing lanes.

Using observational data to assess causal effects of traffic management on air pollutant concentrations has several challenges. First, covariates such as wind speed, wind direction, temperature, relative humidity, and other time of day changes such as traffic volumes or fleet composition, make it difficult to identify if a change in emissions or pollutant levels occurred due to the change in traffic signal timing and related operations. It is also difficult to quantify the true effect size of the traffic variable change with uncontrollable covariates. Second, it is rarely possible to have a control corridor or intersection to compare the empirical evaluation with. Third, due to the lack of replicate sites to perform such testing in, most empirical evaluations around air quality and traffic will be conducted in one place and potentially with a small number of runs which means the data is temporally correlated and these data are not true independent measurements. Thus estimating if an effect occurred and an accurate effect size with a high number of non-independent samples can increase the likelihood of a significant result when there is not one. Despite these challenges, empirical evaluations are important to improve understanding of the actual relationship of varying traffic dynamics on emissions and 
concentrations present in the transportation microenvironment where urban populations spend a significant portion of their time.

This study presents an evaluation of the change in roadside NOx concentrations due to a reduction in maximum cycle length for an intersection operated by an adaptive traffic control system. Cycle length is the amount of time in seconds that it takes to serve each phase or lane group, including left turns, at an intersection. In an urban setting, determining an appropriate maximum time for cycle length is essential to make sure pedestrians can cross an intersection safely and in a timely manner. Due to concerns about pedestrian delay at this study intersection, the maximum cycle length was reduced during two case study periods creating the opportunity for the empirical evaluation presented here. Long-term roadside air quality monitoring of NOx at the study intersection is used to assess these case studies when the maximum cycle length was reduced by $15-20$ seconds.

In order to address the challenges of assessing a causal effect with observational data, propensity score matching (PSM) analysis is applied to the datasets to adjust for variability in covariates. PSM is a specific type of matched sampling methods which are frequently applied in the fields of human health research and social science where the elements of a classical randomized experiment can rarely be met ${ }^{86,87}$. The goal of matched sampling is to use data where the distributions of covariates are more similar across the treated and control group and then a parametric analysis to assess the treatment effect is applied on the matched data sample ${ }^{86,88}$. To meet the assumption of 
independence needed for matching and decrease temporal autocorrelation, a random sampling method on the full datasets is also applied ${ }^{50,86}$.

In section 3.2, we present a hypothesis of how maximum cycle length may affect roadside NOx concentrations. Section 3.3 describes methods for assessing such an effect using PSM and random sampling for autocorrelation on an air quality and traffic dataset. Section 3.4 and 3.5 presents the results on the effects of this traffic signal change for the study intersection and discussion of how accounting for autocorrelation and applying a matched sampling analysis affects the evaluation results. Such statistical techniques are important for future evaluations and assessments of transportation project impacts on air quality.

\subsection{Hypothesis}

The intersection in this study is operated under a Sydney Coordinated Adaptive Traffic Signal System (SCATS) control. Maximum or high cycle length (HCL) in SCATS is a ceiling for cycle length implemented during high traffic volume periods. In an urban setting, it is important to determine an appropriate HCL to ensure that pedestrian phases are served without considerable delay during peak periods. SCATS allocates as much time available for each approach in order to clear high traffic volumes and also considers progression of traffic from one intersection to the next. The SCATS system uses traffic volume data collected from in-ground inductive loop detectors, placed at the stopline of each lane in each intersection, to dynamically set cycle lengths and allocations for green time for each lane group along the corridor. 
During peak periods, the study intersection is operating at saturated or oversaturated capacity. If total cycle length is limited, the theoretical capacity to move the same number of vehicles through the intersection that are queuing during peak periods may be reduced compared to operation at a higher total cycle length. Therefore, if HCL is reduced, we hypothesize that the period of congestion may be prolonged and through this extension of the rush hour periods, roadside NOx may also be higher. As found in Unal et al. (2003) and Kim et al (2014), congested periods at intersections with increased acceleration events and longer queues have shown associations with increased measured NOx emissions ${ }^{25,84}$.

In order for NOx concentrations to be elevated with a reduced HCL, the change in congested traffic flows must also be evident for the study intersection. Degree of saturation (DS) is a measure of used green time divided by actual green time, defined by Equation 1 below where space is referring to spacing between vehicles, where $\mathrm{g}=$ green time, $\mathrm{T}=$ total non-occupancy time, $\mathrm{t}=$ standard space time, $\mathrm{n}=$ number of spaces counted, and $\mathrm{r}=$ remaining phase time.

$$
\begin{array}{ll}
\mathrm{DS}= & \mathrm{g}-(\mathrm{T}-\mathrm{tn}) \\
(\mathrm{g}+\mathrm{r}) & \text { Equation } 1
\end{array}
$$

SCATS measures DS for each lane and reports an overall DS value used in deciding the phase splits and cycle length. DS can be used to assess the level of congestion for the study intersection and by approach/lane group. As congestion increases at an intersection and the queue of vehicles in a lane cannot be cleared in one green phase of the cycle, DS increases. Figure 3.1 shows the relationship of DS with total volumes per a 15 minute 
period and shows that traffic volumes increase as DS increases up to a point. This point is the intersection reaching saturation (DS=100). As DS values increase from 100 to 140 , traffic volumes actually decrease because less vehicles are able to pass through the oversaturated intersection. Figure 3.2 shows an overall increase in roadside $\mathrm{NO}$ and $\mathrm{NO}_{2}$ as DS increases highlighted by the median NOx values (red) per every $10 \%$ increase in DS values. As DS increases, SCATS will use a higher cycle length until the intersection timing hits its maximum setting, the HCL. How a reduction in HCL affects the flow of traffic through measured DS values and then roadside NOx concentrations will be assessed in the subsequent sections.

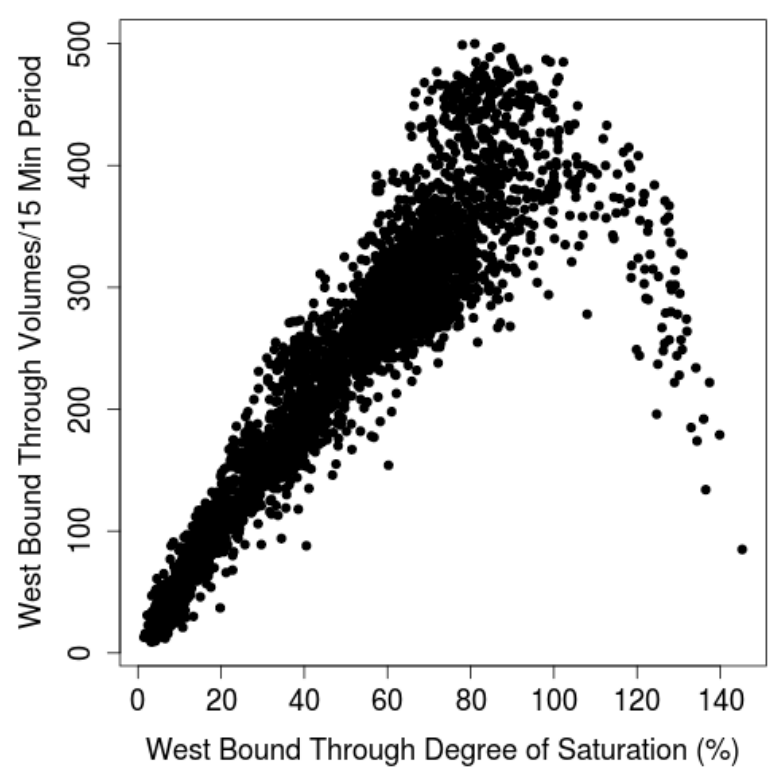

Figure 3.1 Relationship of degree of saturation and traffic volumes for the study intersection. 

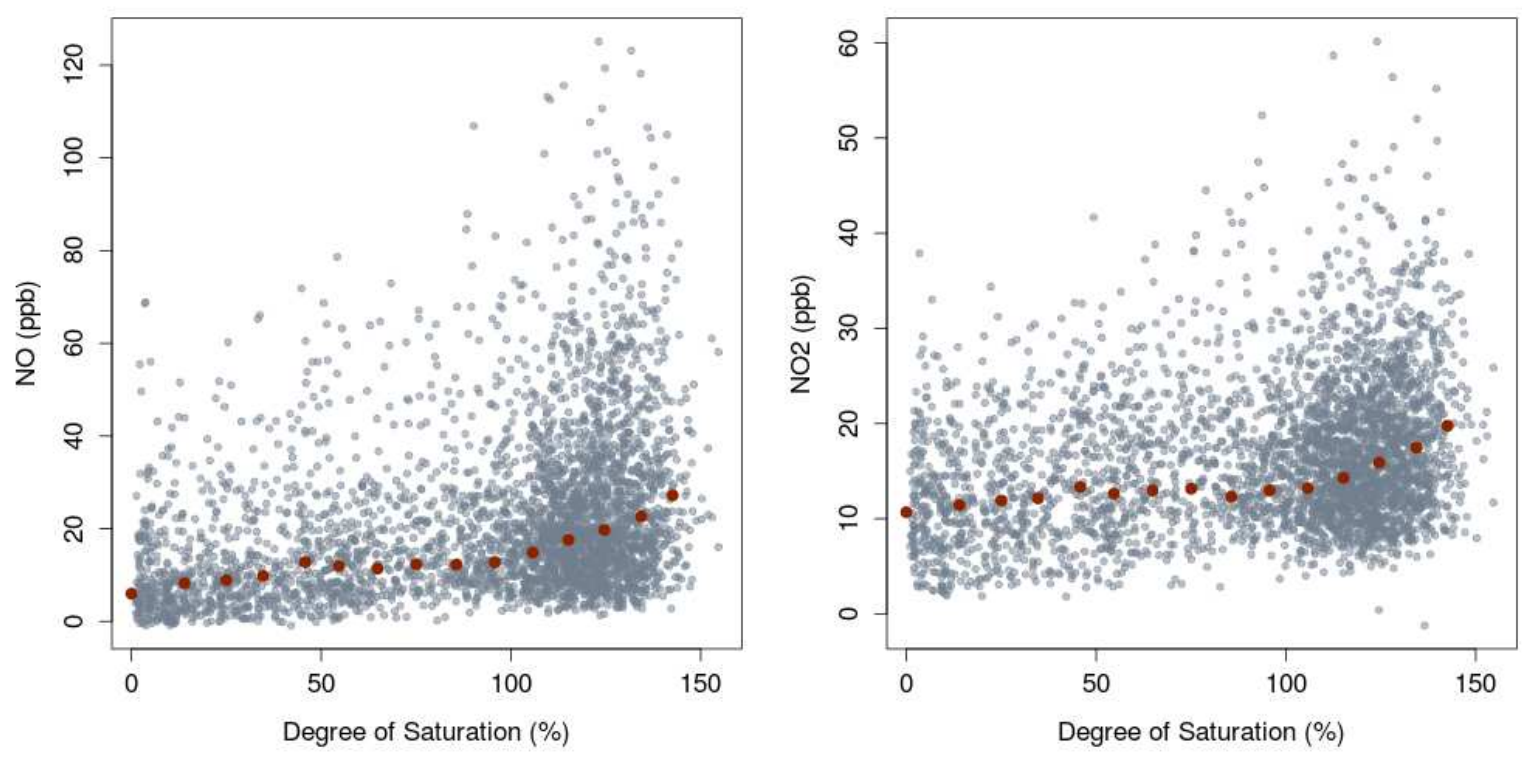

Figure 3.2 Relationship of NOx versus DS for the study intersection. Red points represent the median NOx concentration for every $10 \%$ increase in DS.

\subsection{Methods}

\subsubsection{Case Studies}

Two separate case studies during which the study intersection's HCL was reduced were assessed. The study intersection operated by SCATS is the crossing of SE Powell Blvd and SE $26^{\text {th }}$ Ave. Powell Blvd is major east-west arterial corridor in Portland, OR with peak volumes of 2800 vehicles/hr. SE $26^{\text {th }}$ Ave is a minor north-south route with a major bike crossing and approximately $20 \%$ of the traffic volumes of Powell Blvd. DS values and volumes for each lane and the overall intersection DS were obtained from the SCATS system for all case study evaluation periods. Roadside NOx concentrations were obtained from the continuous air quality monitoring station at the SW corner of the intersection, please refer to Kendrick et al. (2015) for more detailed measurement 
methods ${ }^{50}$. In order to assess the influence of the roadways, measurements with wind coming from the road only were used in the analysis $\left(270^{\circ} \mathrm{W}\right.$ to $365^{\circ} \mathrm{N}$ and $0^{\circ} \mathrm{N}$ to $125^{\circ}$ $\mathrm{SE})$.

Each case study consists of a treatment period with a reduced HCL and a control period when the HCL was not reduced. Table 3.1 shows the details of each treatment and control period for both case studies. The length of the control period varies for each case study depending on the total hours in the treatment period and the occurrence of traffic pattern anomalies due to holidays or accidents. All days in a case study were evaluated for any aberration in diurnal patterns of traffic volumes and DS. If an abnormal pattern was found, the day and time of the abnormality was confirmed/connected to either a known holiday, a known school closing period, road construction, and known traffic incidents resulting in a road closure which were assessed using police and news reports. Data during such events were removed from each case study because the change in traffic was due to an outside influence beyond HCL settings.

Table 3.1 Description of case studies with reduced HCL.

\begin{tabular}{|c|c|c|c|c|}
\hline $\begin{array}{c}\text { Case } \\
\text { Study }\end{array}$ & $\begin{array}{c}\text { Treatment } \\
\text { Period }\end{array}$ & \multicolumn{1}{|c|}{ Control Period } & $\begin{array}{c}\text { Treatment } \\
\text { HCL }\end{array}$ & $\begin{array}{c}\text { Control } \\
\text { HCL }\end{array}$ \\
\hline CS1 & $\begin{array}{l}\text { April 15, 2013- } \\
\text { April 29, 2013 }\end{array}$ & $\begin{array}{l}\text { March 4, 2013- April 14, 2013 } \\
\text { April 30, 2013- June 2, 2013 }\end{array}$ & 120 seconds & 140 seconds \\
\hline CS2 & $\begin{array}{l}\text { July 21, 2014- } \\
\text { Sept 30, 2014 }\end{array}$ & July 11, 2013- Sept 30, 2013 & 125 seconds & 140 seconds \\
\hline
\end{tabular}




\subsubsection{Matched Sampling Analysis}

Roadside NOx has been demonstrated to be responsive to traffic at the study intersection ${ }^{50}$. However, traffic alone does not explain all of the variability in NOx measurements and additional covariates such as wind speed and direction, temperature (as a proxy for boundary layer height) and background pollutant concentrations can affect the magnitude of $\mathrm{NO}$ and $\mathrm{NO}_{2}$ measured at the roadside. In order to directly compare the effect of cycle length on NOx over two different time periods, these additional covariates must be considered. To address the variability due to covariates and the lack of randomization due to the observational nature of our dataset, we apply a matched sampling method, PSM.

The goal in applying a matching analysis method is to improve balance between samples in the control group and samples in the treatment group based on covariates. A balanced sample means the distributions of the covariates for the samples in the control and treatment group are similar. A propensity score is a value that can be used to assess balance and base the matching on. The propensity score is the conditional probability that a sample (i) is assigned to the treatment group $(\mathrm{T}=1)$ given the covariates in $\mathrm{X}$ (Equation $2)^{89}$.

$$
\mathrm{e}\left(\mathrm{X}_{\mathrm{i}}\right)=\mathrm{p}\left(\mathrm{T}_{\mathrm{i}}=1 \mid \mathrm{X}_{\mathrm{i}}\right) \quad \text { Equation } 2
$$

The propensity score ranges from $0-1$ and is used as one value that summarizes all of the covariate variables in $X$. The score is estimated using a logistic regression of $T_{i}$ on a constant term and $\mathrm{X}_{\mathrm{i}}{ }^{86,89}$. 
Depending on the values of the covariates in $\mathrm{X}$, a propensity score or weight will be assigned to each data point. For this analysis, the covariates in $\mathrm{X}$ are continuous variables such as wind speed and temperature which make exact matching very unlikely, compared to a small number of categorical or binary variables. Instead, nearest neighbor matching is used where each treated sample point is matched with a control sample point with the most similar value of the estimated propensity score. Specifically, the analysis here uses the optimal nearest neighbor matching approach developed in the MatchIt $\mathrm{R}$ package which minimizes the total Mahalanobis distance within matched units ${ }^{90,91}$.

Matching is based only on X, the covariates. In order to avoid selection bias in the treatment effect and stacking the deck one way or the other, the response variable $(\mathrm{Y})$ is not considered at all during the matching stage ${ }^{86,89}$. If the response variable for the final parametric analysis, $\left(\mathrm{NO}, \mathrm{NO}_{2}\right.$, and $\mathrm{DS}$ values in our application) were included in building the propensity scores, bias either in over or underestimating the treatment effect could be introduced. Therefore any variable affected by the treatment or tied to the response variable, is excluded in our logistic regression to build the propensity scores. Due to these assumptions, background $\mathrm{NO}$ and $\mathrm{NO}_{2}$ variables were not included in the matching stage because these concentrations are not necessarily independent of roadside NOx and also possibly tied to the treatment of HCL along the corridor due to the location of the background station in close proximity to Powell. Additional methods described in Section 3.3.3 were used to account for the effects of background NOx.

To determine the final covariates used in the logistic regression to estimate propensity scores, regression trees and exploration with linear regression modeling were 
applied to each time period evaluated. These methods were applied to identify covariates with the largest effect on roadside NOx. The matching literature often stresses that all possible covariates of interest in matching should be used. However, Ho et al. (2007) stresses that obtaining good balance on covariates with large effects on the response variable is more critical to reduce bias and variance in treatment effect compared to covariates that have little effect because the large effect covariates will inflate any remaining imbalance in the matched sample ${ }^{86}$. When estimating the propensity scores for each case study evaluation period, the starting point was a full model with all possible covariates. Then balance for each covariate was assessed according to the procedures described below. If balance was not improved as well for the large effect variables identified in the regression tree modeling (wind speed, wind direction, and temperature), a small effect variable would be dropped, new propensity scores built and balance reassessed.

The goal of matching is to optimize balance in the control and treatment sample units while also keeping the highest number of observations in the treatment group as possible. To assess balance, a combination of diagnostic checks was used instead of only evaluating the propensity score values themselves, a procedure outlined by Ho et al. 2007. First, the mean of the differences of each covariate in $X$ were compared, following the rule of thumb proposed by Cochran et al (1968) if one or more of the these differ by more than a quarter of a standard deviation of the respective $\mathrm{X}$ variable, then better balance is needed ${ }^{92}$. Second, quantile-quantile plots (QQ plots) were used to compare the full distributions of the treated and control groups for each variable for unmatched and 
matched data to assess the final matched samples. QQ plots graph the quantiles of a variable of the treatment group against the control group in a square plot and numerically summarize the mean and maximum deviations between the two distributions ${ }^{86}$. Through either of these two assessments, if balance was not improved for large effect variables, the conservative method developed by King and Zeng (2006) to exclude any control units with covariate values outside of the convex hull (Equation 3) of the treated units was applied $^{93}$

$$
\mathrm{X}_{\mathrm{i}}>\max \left(\mathrm{X}_{\mathrm{i}} \mid \mathrm{T}=1\right) \text { and } \mathrm{X}_{\mathrm{i}}<\min \left(\mathrm{X}_{\mathrm{i}} \mid \mathrm{T}=1\right) \quad \text { Equation } 3
$$

Lastly, the region of common support of the propensity scores themselves were assessed visually with histograms to check for similar and overlapping distributions.

Independence of sample units is critical for matching ${ }^{86,88}$. In order to reduce temporal autocorrelation, a subset of data points was randomly selected from each treatment and control time period. The number of points randomly selected was determined by the metric of when the correlation between time lagged response variables ( $\mathrm{NO}$ and $\mathrm{NO}_{\text {lag1 }}, \mathrm{NO}_{2}$ and $\mathrm{NO}_{2 \operatorname{lag} 1}$, and $\mathrm{DS}$ and $\mathrm{DS}_{\text {lag1 }}$ ) was reduced so that correlation coefficients were $\leq 0.5$. The number of data points selected and the change in correlation coefficients for a lag of one are detailed in the results presented for each case study.

\subsubsection{Assessment of Casual Effects}

Assessment of the average causal effect of reduced HCL was performed by applying a t-test on matched samples across the control and treatment periods to assess the difference in means for $\mathrm{NO}, \mathrm{NO}_{2}$, and all $\mathrm{DS}$ values during control and treatment 
periods. Due to the assumptions of normality for the parametric t-test, and the log-normal distributions of measured $\mathrm{NO}$ and $\mathrm{NO}_{2}$, a cube root transformation was applied to these data ${ }^{94}$. These same transformations were applied to background NOx concentrations. Since background $\mathrm{NO}$ and $\mathrm{NO}_{2}$ could not be used as covariates because they are not separate from the response variables, t-tests were also applied to roadside $\mathrm{NO}$ and $\mathrm{NO}_{2}$ divided by background $\mathrm{NO}$ and $\mathrm{NO}_{2}$ (normalized roadside concentrations) across the control and sample periods in order to further understand the effect due to HCL only.

\subsection{Results}

\subsubsection{Case Study 1}

A twenty second reduction in HCL from 140 to 120 seconds was applied to the study intersection for two weeks from April 15, 2013 to April 29, 2013. The reduced HCL altered the cycle length pattern for morning and evening rush hours as shown in Figure 3.3 with grey points representing the diurnal cycle length pattern for the control period and black points the reduced cycle length during the treatment period. Some cycle length values for the control and treatment periods in Figure 3.3 show values above the HCL setting. This happens when SCATS is trying to get the study intersection back into sync with the other intersections in the corridor or if another intersection is out of sync and the cycle length will exceed the HCL using allowable stretch cycle length values. This pattern is also evident in Figure 3.6 for case study 2. Traffic anomalies removed from the control and treatment periods for case study 1 include Portland Public School spring break, a hostage situation on April 22 which closed parts of Powell Blvd, and Memorial Day holiday. The effect of the reduced HCL was evaluated for the end of the 
morning and evening rush hour periods from 8:00-10:00 and from 18:00-20:00 when the signal would be operating at HCL and a change in traffic flow patterns may have occurred based on the hypothesis in section 3.2 .

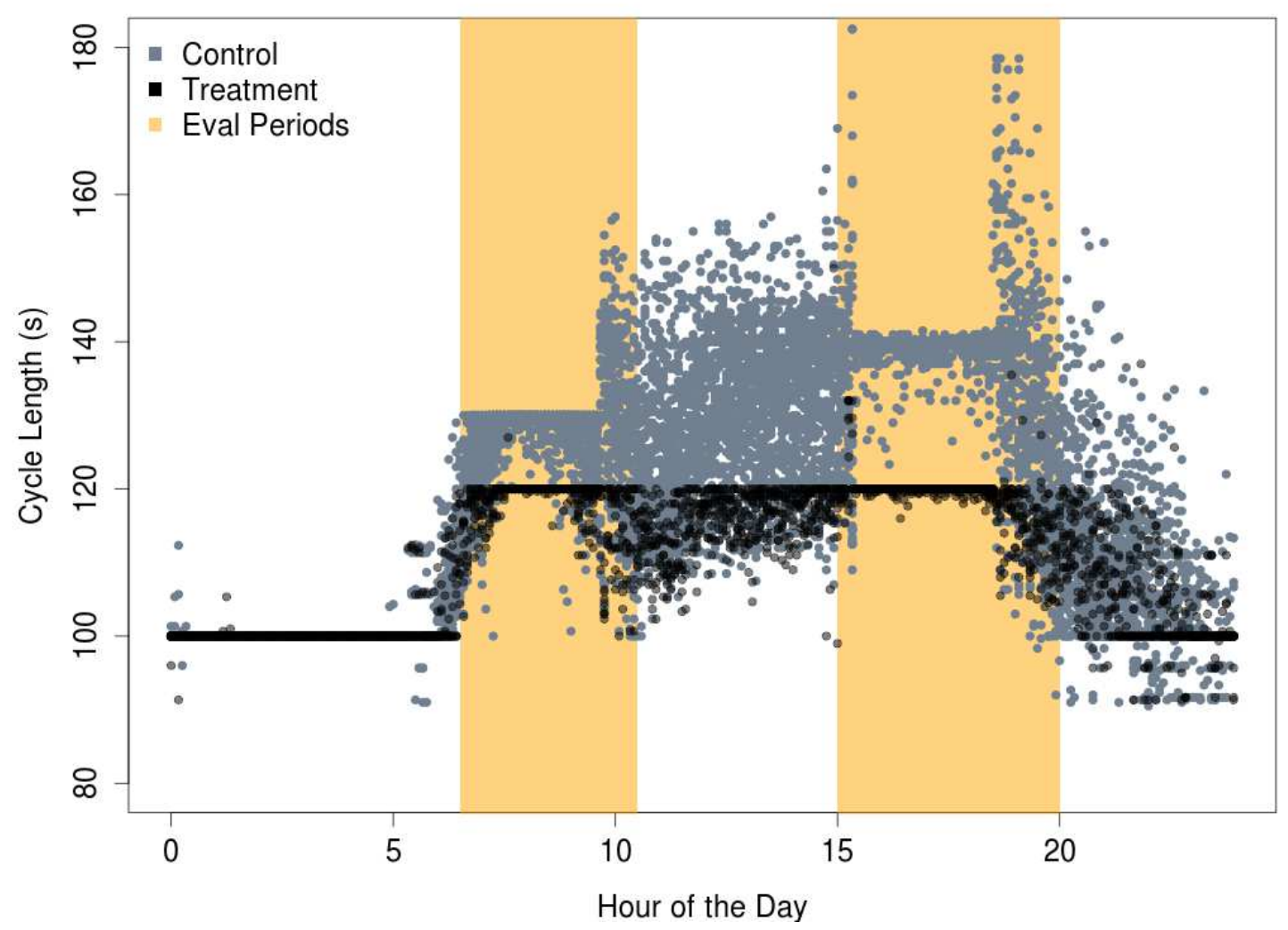

Figure 3.3 Case study 1 with a $20 \mathrm{sec}$ reduction in HCL. Control samples points are in grey, treatment sample points in black, and rush hour periods highlighted in yellow.

Balanced matched samples were found for each dataset that used all treated samples. Table 3.2 shows the matching diagnostics in terms of final sample points matched for each time aggregation ( $5 \mathrm{~min}$ and $15 \mathrm{~min}$ ) for the full datasets and the randomly selected subset. A random sample of 3 points per morning period (8-10am \& 6$8 \mathrm{pm})$ were found to substantially reduce temporal autocorrelation compared to the full 
sample with correlation coefficients for time lagged response variables presented in Table

\section{3 .}

Table 3.2 Case Study 1 Matching diagnostics for total samples matched. Numbers in parentheses are for the full dataset.

\begin{tabular}{|c|c|c|}
\hline $\begin{array}{c}\text { Time Period } \\
\text { Time Aggregation }\end{array}$ & Sample Size Treated Group & Sample Size Matched \\
\hline Morning 5 min & 17 & 17 \\
& $(143)$ & $(143)$ \\
\hline Morning 15 min & 18 & 18 \\
& $(46)$ & $(46)$ \\
\hline Evening 5 min & 25 & 25 \\
& $(188)$ & $(188)$ \\
\hline Evening 15 min & 19 & 19 \\
& $(58)$ & $(58)$ \\
\hline
\end{tabular}

Table 3.3 Case study 1 Summary of correlation coefficients between time-lagged response variables to reduce temporal autocorrelation for Case Study 1 evaluation periods.

\begin{tabular}{|l|c|c|c|}
\hline & $\mathrm{NO} \& \mathrm{NO}_{\operatorname{lag} 1}$ & $\mathrm{NO}_{2} \& \mathrm{NO}_{2 \operatorname{lag} 1}$ & DS \& DS lag1 \\
\hline Full Dataset & 0.75 & 0.55 & 0.92 \\
\hline Morning Subset of 3 pts/period & 0.54 & 0.25 & 0.07 \\
\hline Evening Subset of 3 pts/period & 0.59 & 0.28 & 0.23 \\
\hline
\end{tabular}

Figure 3.4 is an example of a visual check performed to assess improved balance across all of the covariates. The QQ plots of the matched samples on the right hand side of Figure 3.4 show smaller differences across each quintile compared to the relationships using all of the samples in the control and treatment groups. Figure 3.5 shows an example of a strong overlap of the propensity score values themselves in the treatment and control samples in the final matched dataset showing a strong region of common support. QQ 
plots and propensity score histograms for matching conducted across all case study evaluation periods can be found in Appendix B, Figure B-1 through B-20. 

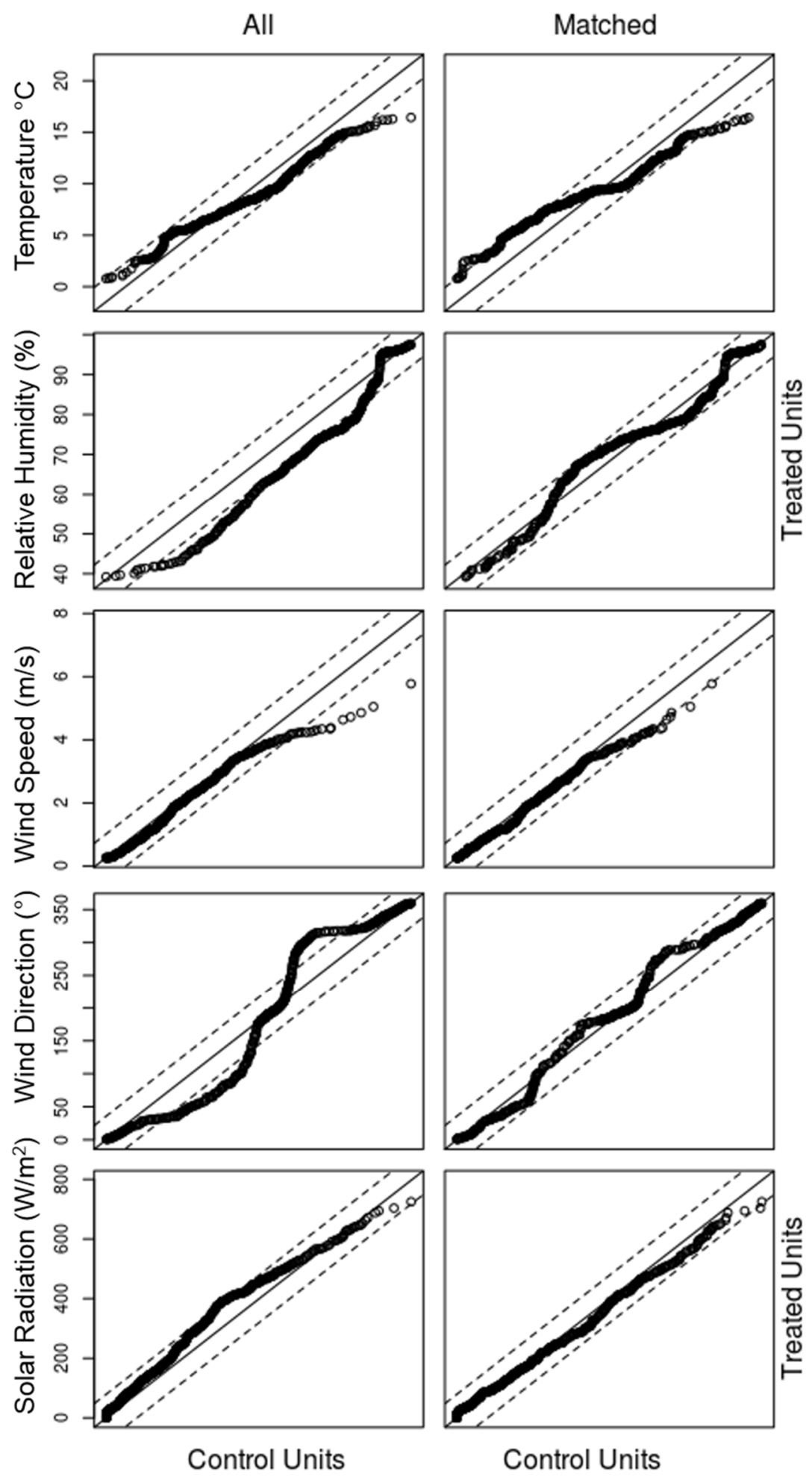

Figure 3.4 Example of QQ plots used to asses balance in matched samples for morning Case Study 1. 


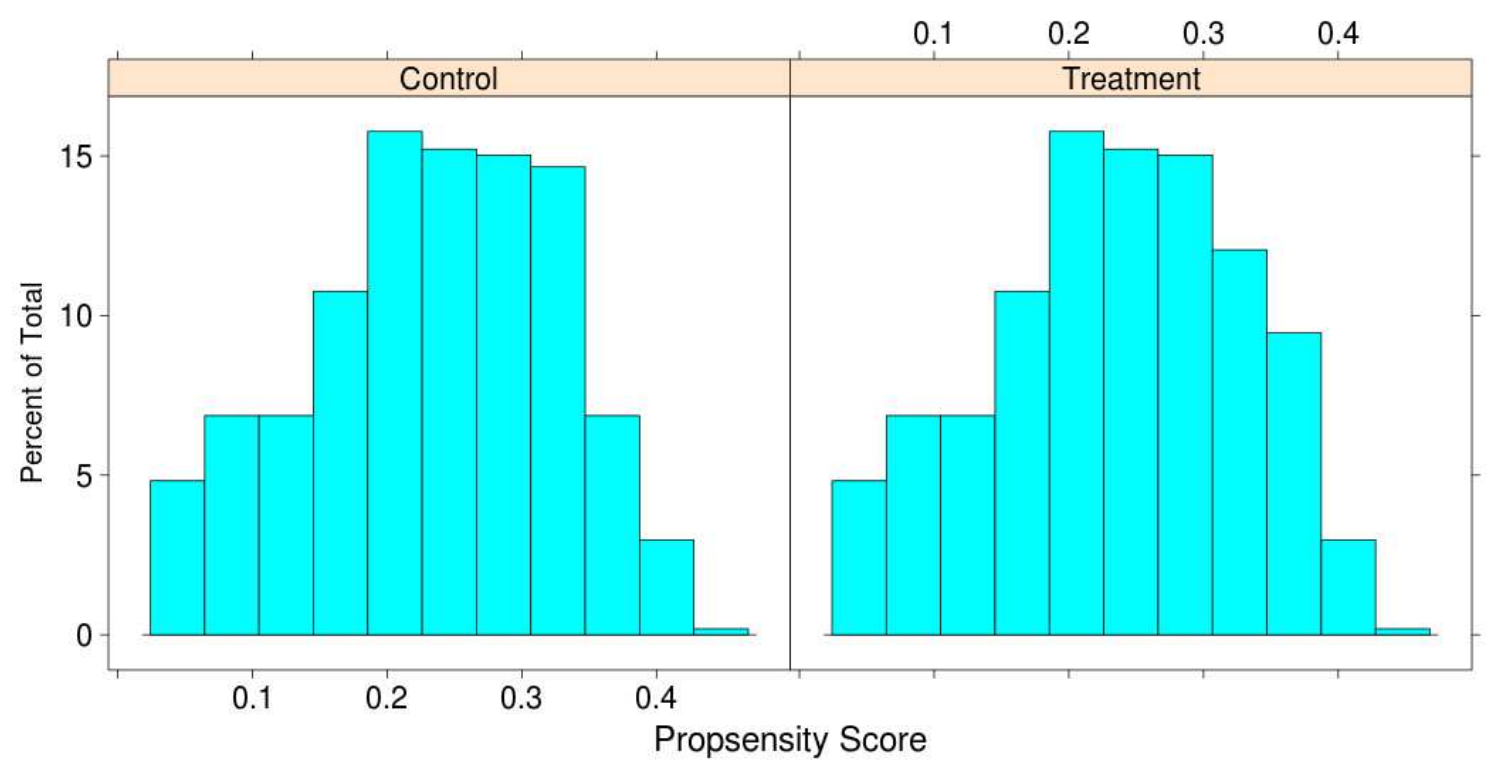

Figure 3.5 Histograms of propensity score values for the control and treatment sample points in the final matched sample for morning case study 1.

\subsubsection{Average Treatment Effect- Case study 1}

Cycle length was significantly reduced during treatment periods in all unmatched and matched samples clearly showing the treatment of reduced HCL was applied. Mean cycle lengths in the morning treatment periods were reduced by 11-13 seconds and 15-17 second reductions were seen in evening mean cycle lengths during the treatment periods. However, for the morning peak period, DS values for the intersection and each approach (westbound, eastbound, and north/southbound) were not significantly different across the control and treatment groups for all matched samples ( $5 \mathrm{~min}, 15 \mathrm{~min}$, full datasets, and subsets). Roadside $\mathrm{NO}$ and $\mathrm{NO}_{2}$ values were not significantly different either across the control and treatment groups in the matched samples. t-test results for all sampling groups including unmatched samples can be found in Appendix B, Tables B1-B5. 
For the evening peak period, $15 \mathrm{~min}$ aggregated DS values for eastbound through lanes $(\mathrm{EBTH})$ were significantly greater $(\mathrm{p}=.02)$ by $7 \%$ and westbound through lanes (WBTH) DS values were greater by $8 \%(\mathrm{p}=0.11)$ for the subset data with reduced temporal correlation. Intersection DS values were also greater by $5 \%$, but only significant in the full dataset. For this same time period and aggregation, normalized NO concentrations were significantly greater after matching $(\mathrm{p}<0.01)$ with a mean difference approximately of 5ppb when back transformed. Mean traffic volumes were higher during the treatment period by 50 vehicles but not significantly different. All other matched sampling evaluation periods showed no significant difference in DS values and no significant difference in roadside NOx concentrations during treatment and control periods. However, when a significant increase in DS occurred across multiple approaches for the study intersection by $5-8 \%$ (15 min subset), a $5 \mathrm{ppb}$ increase in NO was observed during the reduced HCL.

\subsubsection{Case Study 2}

A fifteen second reduction in HCL was applied to the study intersection from July 21, 2014 to Sept 30, 2014. Control sample units were pulled from the time period of July 11, 2013- Sept 30, 2013 to help control for seasonality effects instead of sampling the time periods directly before and after the treatment dates. A host of additional changes to SCATS along the corridor were implemented after Sept 20, 2014 making it unfit to be a control period for HCL conditions as well. Traffic anomalies removed from the control and treatment period include the Labor Day holiday weekend. Figure 3.6 shows the diurnal cycle length patterns for the control (grey points) and treatment periods (black 
points) in case study 2. The effect of the reduced HCL was evaluated for the end of the evening rush hour from 18:00-20:00. In contrast to case study 1, a reduction of 15 seconds versus 20 seconds did not result in a significant difference in cycle length for the morning periods which already have lower cycle lengths compared to evenings. Since no significant difference in cycle length was found for the morning peak period, no further evaluation of DS and NOx changes were performed.

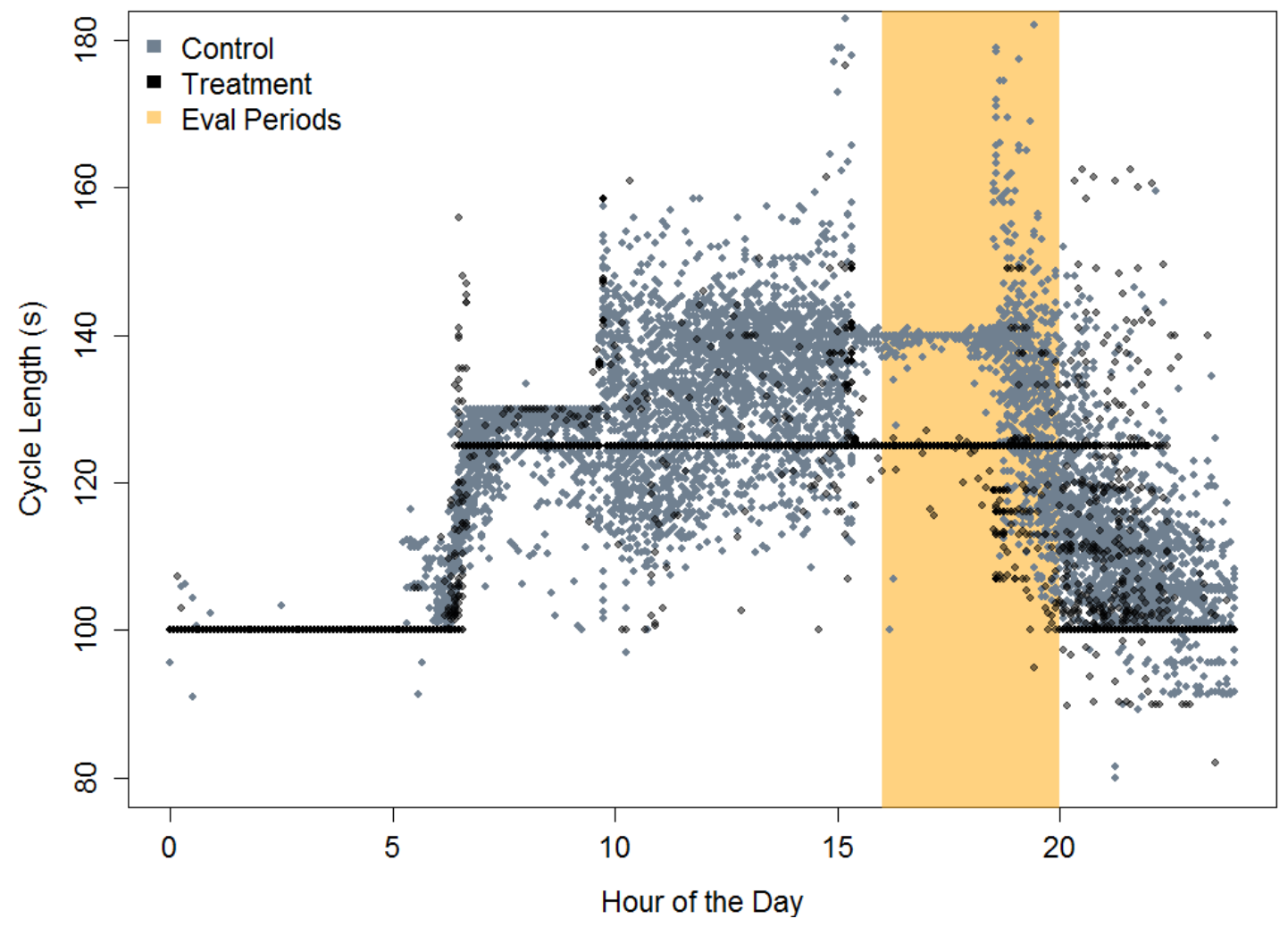

Figure 3.6 Case study 2 with a $15 \mathrm{sec}$ reduction in HCL. Control samples points are in grey, treatment sample points in black, and evening rush hour period highlighted in yellow.

Balanced matched samples were found that used all treated samples for the subset data with reduced temporal correlation. After removing values evaluated for convex hull 
agreement, road wind only, and due to the large sample size in the treatment group, not all treatment samples were matched for the full datasets. Table 3.4 shows the matching diagnostics in terms of final sample points matched for each time aggregation (5 min and $15 \mathrm{~min}$ ) for the full datasets and the randomly selected subset. A random sample of 3 points per morning period were found to substantially reduce temporal autocorrelation compared to the full sample with correlation coefficients for time lagged response variables presented in Table 3.5. QQ plots and propensity score histograms for all subset and full matched samples can be found in Appendix B, Figure B-13 through B-20.

Table 3.4 Case Study 2 Matching diagnostics for total samples matched. Numbers in parentheses are for the full datasets.

\begin{tabular}{|c|c|c|}
\hline $\begin{array}{c}\text { Time Period } \\
\text { Time Aggregation }\end{array}$ & Sample Size Treated Group & Sample Size Matched \\
\hline Evening 5 min & 135 & 135 \\
& $(1052)$ & $(968)$ \\
\hline Evening 15 min & 140 & 140 \\
& $(392)$ & $(342)$ \\
\hline
\end{tabular}

Table 3.5 Summary of correlation coefficients between time-lagged response variables to reduce temporal autocorrelation for Case Study 2 evaluation periods.

\begin{tabular}{|l|c|c|c|}
\hline & $\mathrm{NO} \& \mathrm{NO}_{\operatorname{lag} 1}$ & $\mathrm{NO}_{2} \& \mathrm{NO}_{2 \operatorname{lag} 1}$ & $\mathrm{DS} \& \mathrm{DS}_{\operatorname{lag} 1}$ \\
\hline Full Dataset & 0.74 & 0.62 & 0.94 \\
\hline Evening Subset of 3 pts/period & 0.2 & 0.2 & 0.01 \\
\hline
\end{tabular}

\subsubsection{Average treatment effect- Case Study 2}

Average cycle length values were reduced by $10-11$ seconds during the evening evaluation treatment periods. For the $5 \mathrm{~min}$ matched subset, significantly greater DS values were found for intersection DS ( $>$ by $5, \mathrm{p}=0.08$ ), westbound through ( $>$ by 2 , 
$\mathrm{p}==0.05$ ), and eastbound left turn lane ( $>$ by $5, \mathrm{p}=0.05$ ). Eastbound and north/southbound DS values were greater during the treatment but not significantly different. Roadside NO and $\mathrm{NO}_{2}$ when normalized to background and without normalization were significantly greater during the treatment period by $8 \mathrm{ppb}$ and $5 \mathrm{ppb}$.

The 15 min matched subset also showed a positive average treatment effect of the reduced HCL. Westbound through DS values were greater by 5 ( $<<0.01)$. Intersection DS and eastbound through DS values were on average greater by $3 \%$ but not significant. Eastbound left turn DS was $>$ by $6, \mathrm{p}=0.06$. Roadside $\mathrm{NO}$ and $\mathrm{NO}_{2}$ with and without normalization were significantly greater during the treatment period by $5 \mathrm{ppb}$ and $4 \mathrm{ppb}$. Traffic volumes were not significantly different during the control and treatment periods but were greater on average by about 26 vehicles during the treatment period.

\subsection{Discussion and Conclusion}

In most time periods evaluated for Case Study 1, a reduction in HCL did not result in a significant change in DS values and no significant difference in roadside NO or $\mathrm{NO}_{2}$ concentrations was observed. When a significant change was found for DS values, it was an increase during the reduced HCL period and there was an associated increase in NO as hypothesized in section 3.3. Case study 2 had many more sample points during the treatment period, but even with the data subsets to reduce temporal autocorrelation, significant increases and a more consistent pattern of higher DS values 
during the treatment period were found. Increased $\mathrm{NO}$ and $\mathrm{NO}_{2}$ concentrations were also associated with the treatment period.

Using microsimulation modeling, De Coensel et al. (2012) found that cycle length did not have any significant influence on $\mathrm{NOx}, \mathrm{CO}_{2}$ or $\mathrm{PM}_{10}$ emissions, while traffic flow and green split did significantly affect emissions and explain a majority of the variance in modeled emissions ${ }^{27}$. SCATS is adaptively assigning green time to each phase in each cycle. For the study intersection, Powell Blvd has the highest traffic volumes compared to SE $26^{\text {th }}$ Ave and so higher green times are appropriated to the east and westbound approaches during congested periods. DS values representing a change in traffic flows were affected by cycle length during the treatment periods here for some of the matched samples. For this intersection, traffic flow and green split are not independent of cycle length and the effect of these changes on roadside NOx are in line with modeling found by DeCoensel et al. (2012).

To further quantify the average treatment effect of reduced HCL on DS and roadside NOx, these measurement and analysis methods need to be applied to a larger intersection. The value of a significant increase in DS with a resulting increase in NO and/or $\mathrm{NO}_{2}$ was not consistent across the two case studies evaluated here. During the same treatment period from Case Study 1, HCL was also reduced for the larger intersection of SE Powell Blvd and SE Milwaukie Ave. At this intersection, the northsouth street, Milwaukie has two through approaches in each direction, larger left turn bays, and carries much more traffic then SE $26^{\text {th }}$ Ave in the study intersection. Morning peak DS values and evening DS values for this intersection were found to be significantly 
higher with mean difference values of 8 and $9 \%$ for multiple approaches, a larger and more consistent effect on flow than at the study intersection. Evaluating NOx concentrations at this type of intersection would provide more conclusive results about the effect size of reducing cycle length on roadside NOx.

Without PSM and random sampling to reduce temporal autocorrelation, the conclusions of this evaluation would have been much different. When using the full datasets with non-independent measurements, sample sizes are much larger. This leads to the possibility of finding significant differences when NOx ppb levels or DS values differ by very small values not necessarily reflecting a real world difference. Without matching, covariates can either mask if an effect occurred or overestimate an effect. For case study 2 , most unmatched samples show no significant difference in DS values. However when matched based on similar covariates, the small effect of cycle length on DS is evident. For case study 1 evening, unmatched roadside NO is significantly higher during the treatment period but no DS values are. However, when matched based on similar covariates, we see there is no significant difference in roadside $\mathrm{NO}$ which is consistent with the fact that no change in traffic flow occurred due to the reduced HCL for the $5 \mathrm{~min}$ sub samples. Observational data has many covariates, so any effect of a transportation measure on near-road air quality is likely to be a small signal above a lot of noise or natural variability. In order to assess the presence of effects and improve understanding of a true effect size, matched sampling could prove to be a valuable tool in future empirical evaluations of air quality mitigation strategies or projects. 
Chapter 4 Evaluation of CAL3QHC dispersion modeling for predicting particulate roadside concentrations

Abstract

Dispersion modeling is one of the major tools used to assess Clean Air Act conformity. The California Line Source Dispersion Model with Queuing and Hotspot Calculations (CAL3QHCR) is an approved regulatory model often used to assess the impacts of transportation projects on $\mathrm{PM}_{2.5}$ concentrations. In this study, predicted $\mathrm{PM}_{2.5}$ concentrations are compared with roadside $\mathrm{PM}_{2.5}$ observations for peak traffic volume hours for the months of January 2013 and July 2013 for a signalized intersection in Portland, OR. Using the factor of two criteria, CAL3QHC performed well in predicting $\mathrm{PM}_{2.5}$ concentrations for winter peak traffic periods and poorly in predicting $\mathrm{PM}_{2.5}$ concentrations for summer peak traffic periods. Summer predictions were biased high when observed concentrations were low. $\mathrm{PM}_{2.5}$ concentrations were modeled using three separate input scenarios; modeling scenario one is built using detailed temporal traffic volume and signal data; modeling scenario two is built using snapshot traffic survey data and default values for the queueing algorithm; modeling scenario three is built using free flow links only and the queuing algorithm is not applied. For both winter and summer periods, there were negligible differences in performance across the three scenarios. Lastly, CAL3QHC was used along with roadside PNC measurements to back calculate PNC emission factors for a mixed fleet and major arterial roadway in the U.S. These modeled particle number emission factors are comparable with emission factors calculated for other urban roadways during periods with slower traffic speeds and stop and go traffic patterns. Most field studies estimating in-road PNC emission factors have 
occurred outside of the U.S. The values presented here provide a starting place to estimate total particle number emissions and to build initial particle number emission inventories needed in order to further characterize PNCs from traffic emissions.

\subsection{Introduction}

Dispersion modeling is one of the major tools used to asses Clean Air Act conformity requirements. This process based modeling is used in conjunction with emissions modeling by Metropolitan Planning Organizations (MPOs) and state Departments of Transportation (DOTs) to help build State Implementation Plans (SIPs) and Transportation Improvement Programs (TIPs) for maintenance and non-attainment areas. Dispersion modeling is also used in National Environmental Protection Act (NEPA) applications. Transportation conformity specifically requires dispersion modeling to assess how transportation projects may impact localized PM concentrations. Beginning in 2006 qualitative only $\mathrm{PM}_{2.5}$ hot-spot analyses were required until an appropriate motor vehicle emissions model for project-level analyses was released ${ }^{95}$. With the release of the Motor Vehicle Emissions Simulator (MOVES) emission model in 2009, quantitative PM hot-spot analyses were required with a grace period ending in December $2012^{96}$. Currently, the United States Environmental Protection Agency (U.S. EPA), recommends two air dispersion models for highway and intersection projects; the American Meteorological Society/EPA Regulatory Model (AERMOD) and the California Line Source Dispersion Model with Queuing and Hotspot Calculations (CAL3QHCR). Both are Gaussian dispersion models and this study focuses on evaluation of CAL3QHC. 
Despite known limitations such as not producing valid concentrations under wind speeds $<1 \mathrm{~m} / \mathrm{s}$, overpredictions for parallel wind directions, and improved predictions for receptors furthest from roadsides, $\mathrm{CAL} 3 \mathrm{QHC}$ is applied to near roadway environments to assess $\mathrm{PM}_{2.5}$ for transportation projects ${ }^{97}$. These modeling limitations are common for Gaussian models and have been found with CALINE4 and CAL3QHC in comparisons with measured concentrations ${ }^{98-102}$. CAL3QHC is a Gaussian distribution model with horizontal and vertical dispersion. Motor vehicle emissions along a roadway segment are represented as a line source and each segment or link of the roadway has a defined mixing zone with traffic volume and emission factor inputs. Pollutants then disperse from each mixing zone in a Gaussian distribution and concentrations coming from each mixing zone are summed to calculate the average predicted concentrations at a given receptor 99,103. CAL3QHC has a queueing algorithm to help simulate traffic signal flow patterns and emissions from idling.

Detailed comparison studies of model predictions and measurements for roadside $\mathrm{PM}_{2.5}$ are limited. Chen et al. (2009) evaluated $\mathrm{PM}_{2.5}$ predictions from CALINE4, CAL3QHC and AERMOD using measurements from an intersection in Sacramento, California and CALINE4 and CAL3QHC for an intersection in London ${ }^{104}$. For the U.S. site, hourly modeled concentrations were compared with measurements for ten time periods of about three hours each. CAL3QHC was found to perform moderately well, defined by most measurements falling with the factor-of-two envelope. However, as pollution measurements increased, all models showed a trend of underprediction. In contrast to the Sacramento results, London measurements were available for 253 hours 
from a continuous monitoring roadside site. CAL3QHC modeled results did not match well for measurements paired in space and time. The poorer performance of CAL3QHC for the London site was attributed partly to the fact that the receptor was much closer to the roadside compared to the Sacramento location. Due to the lack of detailed traffic signal-related parameters, the queuing algorithm in CAL3QHC was not used for these evaluations.

When using the queuing algorithm, Gokhale et al. (2008) found CAL3QHC predicted 24 hour average $\mathrm{PM}_{2.5}$ concentrations better than CALINE3 by the assessment of much higher number of predictions falling within the factor-of-two and factor-of-five envelopes ${ }^{102} . \mathrm{PM}_{2.5}$ predictions were evaluated for four winter months for a busy intersection in India with the receptor/measurements occurring $22.4 \mathrm{~m}$ and $75 \mathrm{~m}$ away from the road. Gokhale et al. (2011) also performed a model evaluation for 1 hour and 8 hour $\mathrm{PM}_{2.5}$ averages for three different road types with various scenarios of traffic assessed by field surveys. CAL3QHC and CALINE both underpredicted for all traffic flow scenarios, although CAL3QHC did relatively better at intersections than roundabouts $^{105}$.

The queuing algorithm is not consistently applied in peer-reviewed assessments. CAL3QHC's queuing algorithm requires signal-related data such as average cycle length and average red time for each approach in an intersection. These signal-related data are not typically available for intersections or easy to specify in creating models for project impacts ${ }^{106}$. If such traffic and signal data are available, it is typically in the form of a snapshot survey measured by observing a roadway for a morning and evening peak 
period for one day and applied to other days when modeling. Additionally, the advanced modeling options in MOVES can create composite emission factors which represent acceleration, deceleration and idling emission factors. EPA's hotspot guidance actually recommends not using the queuing algorithm if MOVES emission factors are built according to their project guidelines. Despite this range in modeling setups and various sources of data for research and project applications, a comparison of $\mathrm{PM}_{2.5}$ predictions by CAL3QHC with varying levels of details for the traffic and signal modeling inputs and varying use of the queueing algorithm have not been made before.

In this study, we first compare $\mathrm{PM}_{2.5}$ predictions with observed concentrations across three modeling scenarios for peak hours in the months of January and July 2013. The study intersection is equipped with a continuous air quality monitoring station and is operated by an adaptive traffic signal system which depends on continuous traffic and signal data collected by loop detectors in each lane: modeling scenario one is built using this detailed temporal traffic volume and signal data; modeling scenario two is built using snapshot traffic survey data and default values for the queueing algorithm; modeling scenario three is built using free flow links only and the queuing algorithm is not applied.

Second, CAL3QHC is used to back calculate particle number emission factors for the study's intersection. Urban particle number concentrations (PNCs) are dominated by the ultrafine size range $(<0.1 \mu \mathrm{m})$ and are the result of traffic emissions ${ }^{107,108}$. Ultrafine particles have a high surface area to volume ratio increasing the capacity to carry toxins into the human body, the small size of these particles allows for deep deposition into the alveolar region of the lungs, pulmonary interstitial spaces, and into the circulatory 
system, and lastly, the presence of high numbers of these particles in these sensitive areas

of the lungs can increase inflammation and oxidative stress ${ }^{109,110}$. Through such mechanisms, PNCs have been tied to adverse respiratory and cardiovascular effects, sometimes more so than total particle mass concentrations ${ }^{111-114}$.

$\mathrm{PM}_{2.5}$ mass measurements at the roadside of this study intersection have not shown a strong signal of local traffic ${ }^{50}$. PNCs have been found to be a better marker of traffic emissions than $\mathrm{PM}_{2.5}{ }^{115,116}$. However, PNCs are not typically measured since they are not currently incorporated into most air quality regulations. In the Portland metropolitan area, PNCs were found to vary spatially depending on land use; with the highest concentrations in more urbanized areas and the lowest concentrations in forested areas away from traffic sources (Figure C-4). In order to better quantify exposure to particle numbers and create and validate emission inventories, more measurements and emission factor estimates are needed ${ }^{116-118}$. Episodic measurements of PNCs from the study intersection are presented here and CAL3QHC is applied to inverse model on-road emission factors.

\subsection{Methods}

\subsubsection{Study Intersection}

Near-road $\mathrm{PM}_{2.5}$ concentrations are modeled for the signalized intersection of SE Powell Boulevard and SE $26^{\text {th }}$ Ave in Portland, OR. SE Powell Boulevard is a major east/west arterial corridor with two through lanes, left turn bay, and right turning lane in 
the eastbound direction and two through lanes plus a left turn bay in the westbound direction. Both the north and southbound approaches on SE $26^{\text {th }}$ Ave contain a through lane, left turn bay, and a bike lane with a bicycle box which places the stop line of the vehicles in the through lanes approximately 10 feet back from the sidewalk. Figure 4.1 shows a schematic of the study intersection depicting all approaches as well as the links used in the model setup. For each through approach, there is an approach link that extends into the middle of the intersection and then a depart link. For each through approach and turning approach, there is a queue link which ends at the stop line of each approach.

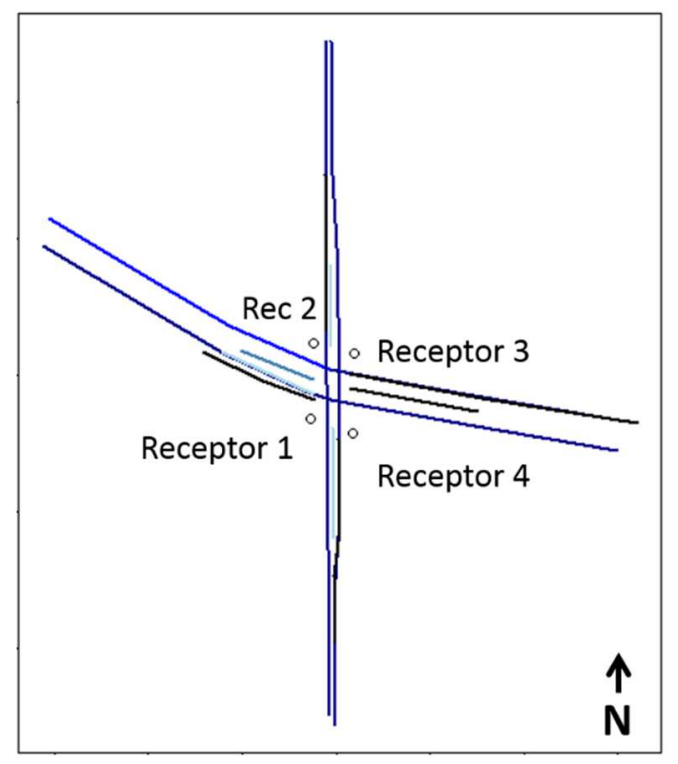

Figure 4.1 SE Powell Blvd and SE $26^{\text {th }}$ Ave intersection setup with links and receptors for dispersion modeling.

\subsubsection{Comparisons with Observed $\mathrm{PM}_{2.5}$ Concentrations}

All modeled $\mathrm{PM}_{2.5}$ concentrations are compared with roadside $\mathrm{PM}_{2.5}$ measurements obtained from the air quality monitoring station located $1 \mathrm{~m}$ from the 
southwest corner (Receptor 1, Figure 4.1) of the study intersection. $\mathrm{PM}_{2.5}$ measurements are made using a TSI DRX DustTrak with a sampling inlet approximately $2.5 \mathrm{~m}$ above the sidewalk. Details on the monitoring station setup and methodology can be found in Kendrick et al. $(2015)^{50}$. Background $\mathrm{PM}_{2.5}$ levels were obtained from the Oregon Department of Environmental Quality's (DEQ) regional monitoring station located 3.4 $\mathrm{km}$ east of the roadside station and $0.09 \mathrm{~km}$ south of Powell Boulevard. Data from this background station is collected, stored and accessed through the Portland Horizons database ${ }^{58}$. The peak morning (8am) and peak evening $(5 \mathrm{pm})$ hours are modeled for each day in January 2013 and July 2013. Observed roadside and background $\mathrm{PM}_{2.5}$ distributions, median, and mean concentrations for these time periods are summarized in Table 4.1.

Table 4.1 Summaries of roadside and urban background $\mathrm{PM}_{2.5}$ observations for the modeled dates and times.

\begin{tabular}{|c|c|c|c|c|}
\hline \multirow[b]{2}{*}{ Observation Period } & \multicolumn{2}{|c|}{ 8am Peak Hour } & \multicolumn{2}{|c|}{ 5pm Peak Hour } \\
\hline & $\begin{array}{c}\text { Roadside } \\
\text { Mean } \\
\text { Median } \\
\left.\text { (5 } 5^{\text {th }}-95^{\text {th }} \text { Percentiles }\right) \\
\end{array}$ & $\begin{array}{c}\text { Urban Background } \\
\text { Mean } \\
\text { Median } \\
\left(5^{\text {th }}-95^{\text {th }} \text { Percentiles }\right)\end{array}$ & $\begin{array}{c}\text { Roadside } \\
\text { Mean } \\
\text { Median } \\
\text { (5 } 5^{\text {th }}-95^{\text {th }} \text { Percentiles) } \\
\end{array}$ & $\begin{array}{c}\text { Urban Background } \\
\text { Mean } \\
\text { Median } \\
\left(5^{\text {th }}-95^{\text {th }} \text { Percentiles }\right)\end{array}$ \\
\hline January 2013 & $\begin{array}{c}17 \\
16 \\
(2-35) \\
\end{array}$ & $\begin{array}{c}9 \\
8 \\
(1-23) \\
\end{array}$ & $\begin{array}{c}16 \\
13 \\
(2-32) \\
\end{array}$ & $\begin{array}{c}11 \\
7 \\
(2-27) \\
\end{array}$ \\
\hline July 2013 & $\begin{array}{c}2 \\
2 \\
(1-4)\end{array}$ & $\begin{array}{c}4 \\
4 \\
(2-9)\end{array}$ & $\begin{array}{c}2 \\
1 \\
(0-3)\end{array}$ & $\begin{array}{c}4 \\
3 \\
(2-7)\end{array}$ \\
\hline
\end{tabular}

Measurements and predictions are compared using factor of two plots and criteria. The factor-of-two criteria and plot are commonly used to assess dispersion model performance and if $75-80 \%$ of points fall inside this envelope the results are considered 
good predictions ${ }^{104,119}$. Predictions and observations are first compared conservatively, paired in space and time by directly comparing predictions only at receptor 1 (SW corner). To understand the range of predicted concentrations for the study intersection's roadside environment, a receptor was also placed on each corner (receptors 2-4, Figure 4.1). By having a receptor in each direction, roadside concentrations predicted regardless of wind direction would be reported. Observations are compared paired in time only using predictions from all receptors.

\subsubsection{Model Scenarios}

CAL3QHC was setup using three different scenarios. The model inputs in each scenario were built using varying levels of detail in emissions, traffic and signal (ETS) data. Each scenario is summarized below in Table 4.2. The model inputs and data sources are described in detail in the following sections. For each scenario, CAL3QHC was run to simulate $\mathrm{PM}_{2.5}$ concentrations for the morning peak hour (8am) and evening peak hour (5pm) for the months of January 2013 and July 2013 to capture seasonal differences. Since the traffic survey data used for Scenario 2 was only available for weekdays, only weekdays are modeled for all three scenarios. Hourly traffic volume and meteorological data are typically more readily available so are used in both scenarios 1 and 3 . 
Table 4.2 Model scenarios based on varying levels of detail available in emissions, traffic, and signal data for modeling inputs.

\begin{tabular}{|c|c|c|}
\hline Scenario & ETS Data Overview & $\begin{array}{l}\text { Queuing } \\
\text { Algorithm }\end{array}$ \\
\hline $\begin{array}{c}\text { S1 } \\
\text { Most Detailed }\end{array}$ & $\begin{array}{l}\text { - Continuous, hourly traffic volumes } \\
\text { - Continuous hourly signal data } \\
\text { - Emission factors based on } \\
\text { measured, hourly average speeds }\end{array}$ & Yes \\
\hline $\begin{array}{c}\text { S2 } \\
\text { Snapshot }\end{array}$ & $\begin{array}{l}\text { - Snapshot traffic survey volumes } \\
\text { - Signal data based on static signal } \\
\text { timing plan and default values } \\
\text { Emission factor based on speeds } \\
\text { from snapshot traffic survey }\end{array}$ & Yes \\
\hline $\begin{array}{c}\text { S3 } \\
\text { No traffic } \\
\text { signal } \\
\text { simulated }\end{array}$ & $\begin{array}{l}\text { - Continuous, hourly traffic volumes } \\
\text { - No traffic signal variables needed } \\
\text { - Emission factors based on } \\
\text { measured, hourly average speeds }\end{array}$ & No \\
\hline
\end{tabular}

\subsubsection{Model Inputs}

SE Powell Boulevard is operated by the Sydney Coordinated Adaptive Traffic

Signal System (SCATS). SCATS uses inductive loop detectors to collect continuous measurements of traffic volumes by lane and SCATS records the real-time dynamic cycle lengths, phase time for each approach, and degree of saturation (measure of total green time and available green time describing level of congestion) to determine how each approach is served in the next cycle and manage throughput on the main arterial throughout the corridor. These data were used for Scenario 1 model inputs as described below. 


\subsubsection{Traffic Volumes}

For Scenarios 1 and 3, traffic volumes for each lane were pulled from SCATS for every date and hour modeled. To determine approach and depart volumes, turning lane volumes were added to the appropriate directional depart volume. For Scenario 2, traffic volumes for peak hours were pulled from PortlandMaps which stores periodic traffic survey data ${ }^{55}$. Surveys were completed for the North and South direction on June 19, 2013, and August 5, 2013 and for the East and West approaches of the study intersection on June 19, 2013 and Feb 2 \& 26, 2014. The hourly AM and PM peak volumes for each approach were used as static inputs when running the model using the setup from Scenario 2. The traffic survey volumes were made at locations just past the intersection so to account for turning lane volumes, percentages of total approach volumes for each turning lane were determined from the SCATS data and then applied to the traffic survey data.

\subsubsection{Signal Inputs}

When using the queuing algorithm in CAL3QHC, average total cycle length, average red time for each approach, and average saturation flow rates for each approach are required inputs. Cycle lengths and red time from SCATS were averaged on an hourly basis and applied for each hour and date for scenario 1. Signal timing plans for the study intersection show set ratios of how to split green and red times for an intersection based on time of day. The signal timing plan available for the study intersection is from before the adaptive signal system was implemented. In order to still compare apples to apples, the cycle lengths and red times for each approach were averaged for each peak hour over 
the whole month. These values averaged over the whole month were then used as static inputs for cycle length and approach red time for scenario 2 . Arrival type for both scenarios using the queuing algorithm was set equal to the value of three, representing the average conditions during peak periods.

Saturation flow rate is not a variable that could be continuously measured. Saturation flow rate is typically treated as a steady maximum flow rate at which queuing vehicles are discharged into the intersection after a signal changes to green and is then used to determine capacity if the signal variables are known ${ }^{120}$. Also defined as the vehicles per hour during effective green time. Morning and evening saturation flow rates for each direction were empirically collected using the field measurement technique for saturation flow rate from the 2010 Highway Capacity Manual methodology by watching recorded video from the winter of 2014 and direct observations at the intersection in the summer of $2015^{121}$. Additionally, saturation flow rates for turning lanes were derived values outlined by Wang and Benekohal (2010) ${ }^{122}$. The empirically derived saturation flow rates were used for Scenario 1. For scenario 2, which represents the common situation of having limited traffic and signal data resources, the recommended default of 1600 from the CAL3QHC user's guide for an urban intersection was used.

\subsubsection{Emission Factors}

Speed-based $\mathrm{PM}_{2.5}$ emission factors for arterials ranging from 2-60mph and idling emission factors were provided by modelers at Metro (Portland's regional government) based on the 2014 MOVES outputs produced for Metro's 2014 Regional Transportation Plan (RTP) $)^{123,124}$. Composite emission factors accounting for characteristics of both 
Oregon and Washington fleets were used. The speeds to determine speed-based emission factors for free-flow links were based on travel time data collected using a method that utilizes Bluetooth data developed by Quayle et al. (2010) ${ }^{125}$. The travel time data was accessed from the Portland Oregon Regional Transportation Archive Listing (PORTAL), converted to speed over a known distance, and averaged over 60 minute intervals for the peak periods modeled. Emission factors for free-flow links in scenarios 1 and 3 were dynamically selected based on the median speed for the hour and date modeled. Scenario 2 used a static emission factor based on the median speed values for North and South directions from PortlandMaps survey data and median speeds for the East and West 8am and 5pm hours from the Bluetooth data. These speeds and emission factors are summarized in Table 4.3

Table 4.3 Summary of hourly averaged speeds and emission factors (EF) for all model scenarios.

\begin{tabular}{|c|c|c|c|c|c|c|c|c|}
\hline & \multicolumn{2}{|c|}{ Scenario 1 and 3} & \multicolumn{2}{|c|}{ Scenario 2} & \multicolumn{2}{|c|}{ Scenario 1 and 3} & \multicolumn{2}{|c|}{ Scenario 2} \\
\hline $\begin{array}{l}\text { Modeling } \\
\text { Period }\end{array}$ & $\begin{array}{c}\text { East } \\
\text { Bound } \\
(\mathrm{mph}) \\
\min \\
\max \end{array}$ & $\begin{array}{l}\text { Speed } \\
\text { Based } \\
\text { EF } \\
\text { (g/mile) }\end{array}$ & $\begin{array}{c}\text { East } \\
\text { Bound } \\
\text { (mph) } \\
\text { median }\end{array}$ & $\begin{array}{c}\text { Speed } \\
\text { Based } \\
\text { EF } \\
\text { (g/mile) }\end{array}$ & $\begin{array}{c}\text { West } \\
\text { Bound } \\
\text { (mph) } \\
\text { min } \\
\text { max }\end{array}$ & $\begin{array}{c}\text { Speed } \\
\text { Based } \\
\text { EF } \\
\text { (g/mile) }\end{array}$ & $\begin{array}{l}\text { West } \\
\text { Bound } \\
\text { (mph) } \\
\text { median }\end{array}$ & $\begin{array}{c}\text { Speed } \\
\text { Based } \\
\text { EF } \\
\text { (g/mile) }\end{array}$ \\
\hline $\begin{array}{c}\text { Jan } \\
2015 \\
8 \mathrm{am}\end{array}$ & $\begin{array}{l}24 \\
34\end{array}$ & $\begin{array}{l}0.0433 \\
0.0345\end{array}$ & 29 & 0.0396 & $\begin{array}{l}12 \\
37\end{array}$ & $\begin{array}{l}0.0598 \\
0.0333\end{array}$ & 20 & 0.0493 \\
\hline $\begin{array}{c}\text { Jan } \\
2015 \\
5 p m \\
\end{array}$ & $\begin{array}{l}18 \\
26\end{array}$ & $\begin{array}{l}0.0518 \\
0.0413\end{array}$ & 22 & 0.0463 & $\begin{array}{l}21 \\
29\end{array}$ & $\begin{array}{l}0.0478 \\
0.0396\end{array}$ & 26 & 0.0413 \\
\hline $\begin{array}{c}\text { July } \\
2015 \\
8 \mathrm{am}\end{array}$ & $\begin{array}{l}13 \\
30\end{array}$ & $\begin{array}{l}0.0449 \\
0.0308\end{array}$ & 28 & 0.0316 & $\begin{array}{l}14 \\
32\end{array}$ & $\begin{array}{l}0.0438 \\
0.0288\end{array}$ & 24 & 0.0339 \\
\hline $\begin{array}{c}\text { July } \\
2015 \\
5 \mathrm{pm}\end{array}$ & $\begin{array}{l}11 \\
24\end{array}$ & $\begin{array}{l}0.0473 \\
0.0339\end{array}$ & 14 & 0.0438 & $\begin{array}{l}20 \\
30\end{array}$ & $\begin{array}{l}0.0378 \\
0.0308\end{array}$ & 23 & 0.0349 \\
\hline
\end{tabular}




\subsubsection{Meteorology}

Hourly meteorological data is more readily available for modeling projects so for all three scenarios, hourly average wind speed and directions are used as inputs according to the date and time being simulated (Figure 4.2). Wind data was collected at the intersection as part of the air quality cabinet (RM Young 3D Sonic Anemometers Model 81000) and also supplemented with measurements from the DEQ urban background station 

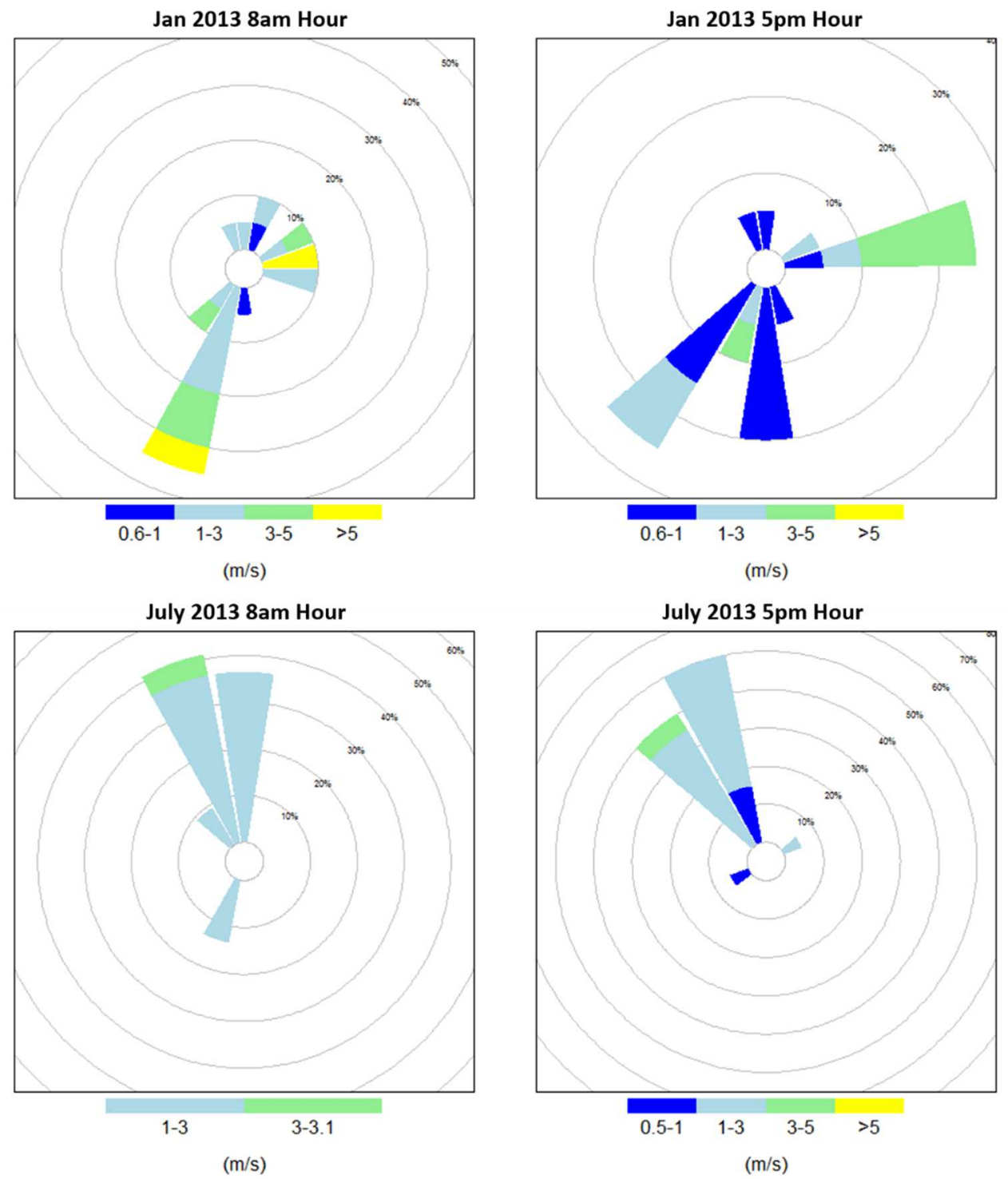

Figure 4.2 Windroses for January and July peak hours modeled.

Stability class was determined using the relationships put forth by Pasquill et al. (1961) and key stability categories in Turner et al. (1969) in which stability category is estimated from wind speed and incoming solar radiation during the day ${ }^{126,127}$. Hourly 
average wind speeds and solar radiation from the DEQ background site were used to determine the stability class A-G (1-7) for each date and time modeled.

\subsubsection{5 $P M_{2.5}$}

Due to the small size of $\mathrm{PM}_{2.5}$, deposition and settling velocities were set to 0 , a

method commonly employed in research and regulatory $\mathrm{PM}_{2.5}$ modeling ${ }^{96,104}$. Background concentrations were also set to 0 which is commonly recommended in guidance documents and then the background concentrations are added to the $\mathrm{PM}_{2.5}$ predicted concentrations. Background concentrations added to modeled values in this study are from the DEQ site and summarized in Table 4.1.

\subsubsection{Particle Count Measurements and Modeling}

Spanning across Sept 21, 2013 to April 2, 2014, 339 hours of PNC measurements were made at the study intersection using a TSI P-Trak particle counter. Measurements were made typically from 5am to $10: 30 \mathrm{pm}$ and the alcohol wick was recharged every 6 hours. Figure 4.3 shows the diurnal distributions of weekday and weekend PNC measurements. There is a clear difference in range of concentrations and diurnal pattern reflecting the higher traffic volumes on weekdays and the distinct morning and evening traffic peaks versus a later, single traffic peak on the weekends. $\mathrm{PM}_{2.5}$ mass concentrations did not show a strong difference across weekdays and weekends for the study intersection (Table 2.1). 


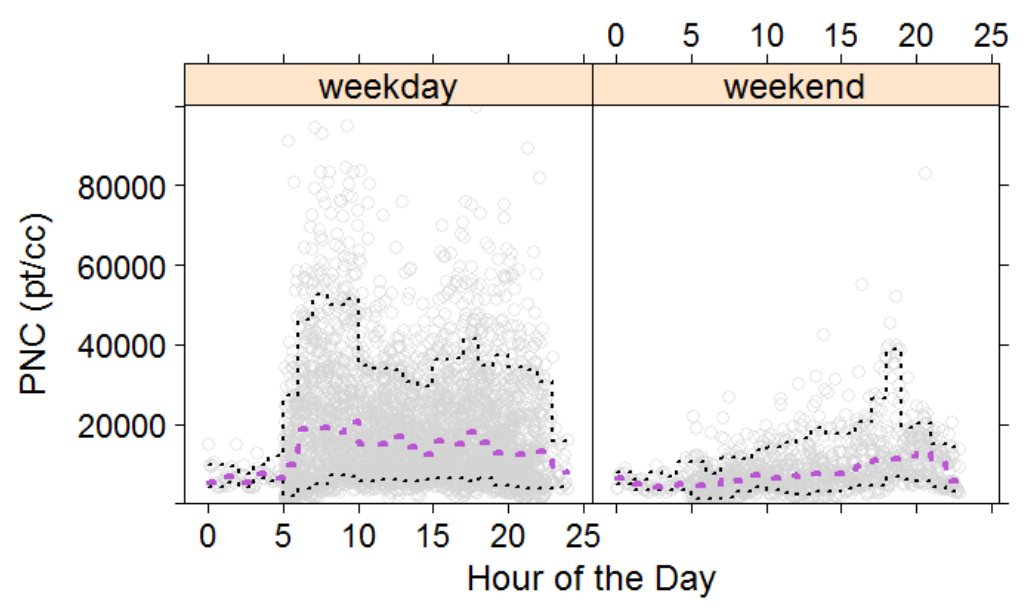

Figure 4.3 Weekday and weekend PNC diurnal distributions. Purple line is the 50th percentile, black lines are the 10th and 90th percentile, and individual points in light grey.

Since PNC roadside measurements do show a relationship with local traffic, the morning 8am and evening 5pm peak hour periods on the days when PNC measurements occurred were modeled using CAL3QHC. These simulations were run the setup of scenario 3 with hourly based traffic and meteorological data as inputs. Scenario 3's model setup was chosen based on model comparison results described in subsequent sections. Predicted particle concentrations were matched to observed PNC measurements and that ratio was used to back calculate a particle number emission factor for each time period. There is a limit to the number of digits visible in the CAL3QHC outputs so the emission factor and predicted values were scaled up. This method was confirmed applicable because the relationship between the emission factor and predicted concentration is linear. CAL3QHC was run in particle mode with deposition and settling velocity set to zero. 


\section{3 Results and Discussion}

\subsection{1 $\mathrm{PM}_{2.5}$ Predictions}

The range of predicted $\mathrm{PM}_{2.5}$ concentrations without background for all three modeling scenarios is summarized in Table 4.4 by season and the 8 am and 5 pm hours. The majority of predicted concentrations for all three scenarios and both seasons ranged from 0 - $2 \mu \mathrm{g} / \mathrm{m}^{3}$. The higher concentrations from $4-8 \mu \mathrm{g} / \mathrm{m}^{3}$ occurred on days with wind speeds less than $1 \mathrm{~m} / \mathrm{s}$ as shown in Figure 4.4. Considering predictions when wind speeds are greater than $1 \mathrm{~m} / \mathrm{s}$, the values predicted here for traffic contributions are similar to other studies and reports for arterial roadways. Lin and Vallamsundar et al. (2013) found contributions from traffic of $0-3 \mu \mathrm{g} / \mathrm{m}^{3}$ and $0-1.5 \mu \mathrm{g} / \mathrm{m}^{3}$ for two separate arterial projects $^{128}$. The limitations of CAL3QHC performance under low wind speeds are well documented and when using CAL3QHCR for hot-spot guidance all calm time periods (wind speeds $<1 \mathrm{~m} / \mathrm{s}$ ) are flagged and not used in calculating final daily or annual concentrations. For the rest of the analysis, these low wind speed hours are excluded.

Table 4.4 Range of predicted $\mathrm{PM}_{2.5}\left(\mu \mathrm{g} / \mathrm{m}^{3}\right)$ from traffic for each peak hour by season.

\begin{tabular}{|c|c|c|c|c|c|}
\hline Winter & $8 a m$ & $5 \mathrm{pm}$ & Summer & $8 \mathrm{am}$ & $5 \mathrm{pm}$ \\
\hline Scenario 1 & $0-3$ & $0-4$ & Scenario 1 & $0-1$ & $0-8$ \\
\hline Scenario 2 & $0-4$ & $0-5$ & Scenario 2 & $0-2$ & $0-8$ \\
\hline Scenario 3 & $0-4$ & $0-5$ & Scenario 3 & $0-1$ & $0-8$ \\
\hline
\end{tabular}



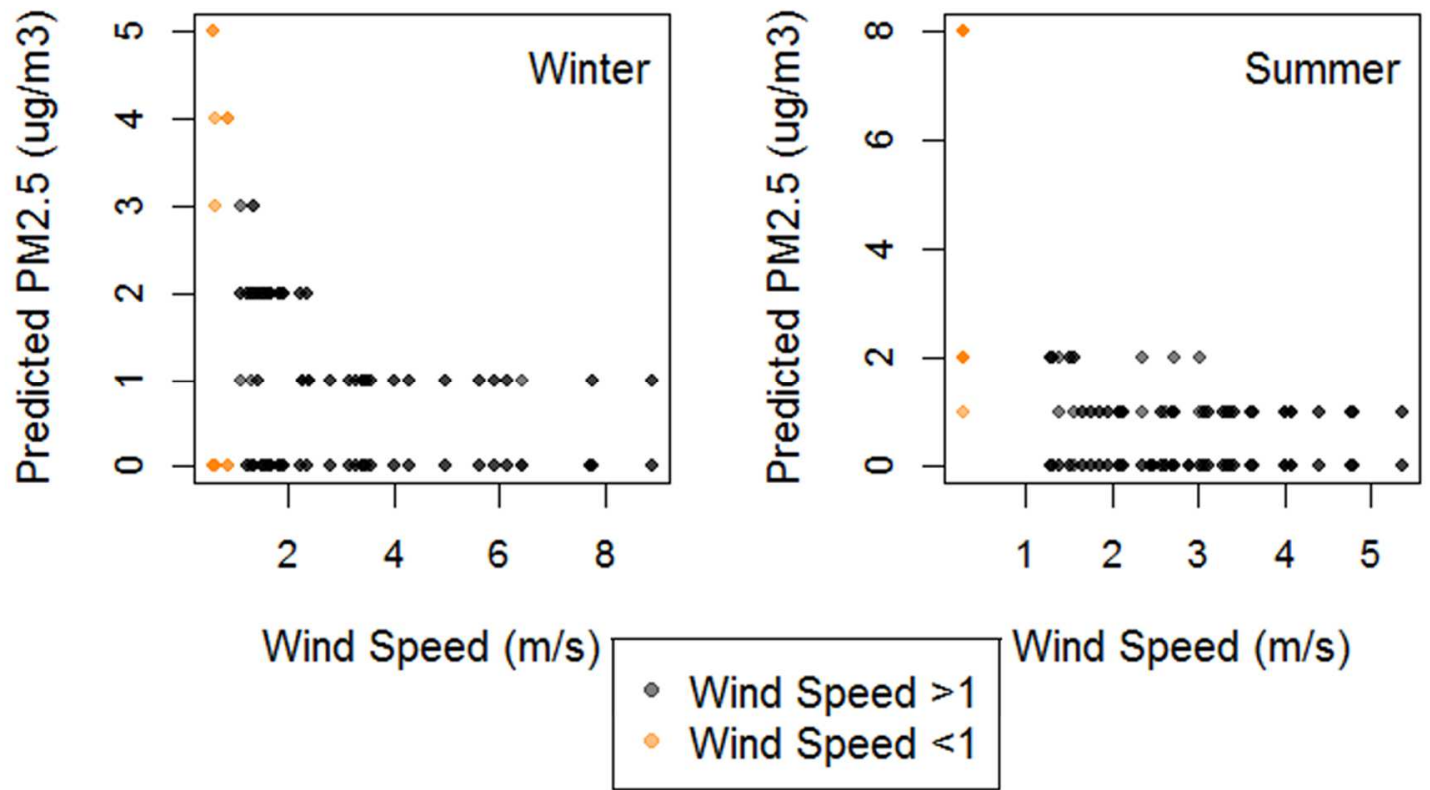

Wind Speed $(\mathrm{m} / \mathrm{s})$

Figure 4.4 Predicted $\mathrm{PM}_{2.5}$ versus wind speed for model scenario 2. Transparent orange represents predictions when wind speed is $<1 \mathrm{~m} / \mathrm{s}$ and transparent black represents predictions when wind speeds $>1 \mathrm{~m} / \mathrm{s}$. Darker colors on the plot show overlapping points.

\subsubsection{Comparisons with Observations}

All comparisons with observations are made using predicted $\mathrm{PM}_{2.5}$ concentrations with background included. When paired in space and time, winter predicted concentrations match well with roadside measured $\mathrm{PM}_{2.5}$ concentrations (Figure 4.5). Table 4.5 summarizes the percentage of points falling within the factor of two envelope for each winter modeled scenario broken up by peak hours and all hours. When paired in space and time, $86-87 \%$ of all points fall within the factor of two envelope for the winter morning hour of $8 \mathrm{am}$ and $100 \%$ of the points do for the $5 \mathrm{pm}$ hour in winter across all three scenarios. Winter results continue to show good model performance when paired only in time and all receptors are considered (Figure 4.6). The percentage of points within the factor of two envelope increase slightly to $93 \%$ for the morning hour in all three 
scenarios and decrease slightly to range from $94-97 \%$ for the evening peak hour across all three scenarios (Table 4.5).

Model performance is poor for the summer results with 19-24\% (morning hour) and $6 \%$ (evening hour) of predictions falling within the factor of two envelope for the SW corner receptor only (Figure 4.7, Table 4.6). When paired in time only, model performance slightly improves but does not meet the factor of two criteria showing only $23-25 \%$ (morning) and 11\% (evening) of predictions falling within the factor of two envelope (Figure 4.8, Table 4.6). Using the same factor of two criteria, Chen et al. (2009) found $100 \%$ of hourly predictions to be within the factor of two envelope for both a California near-road site and a London roadside with background concentrations included, but $69 \%$ and $59 \%$ without background included ${ }^{104}$. Gokhale et al. (2008) found $66 \%$ of 24 hour $\mathrm{PM}_{2.5}$ predictions to be within a factor of two of measurements for a near-road site at an intersection in India ${ }^{102}$.
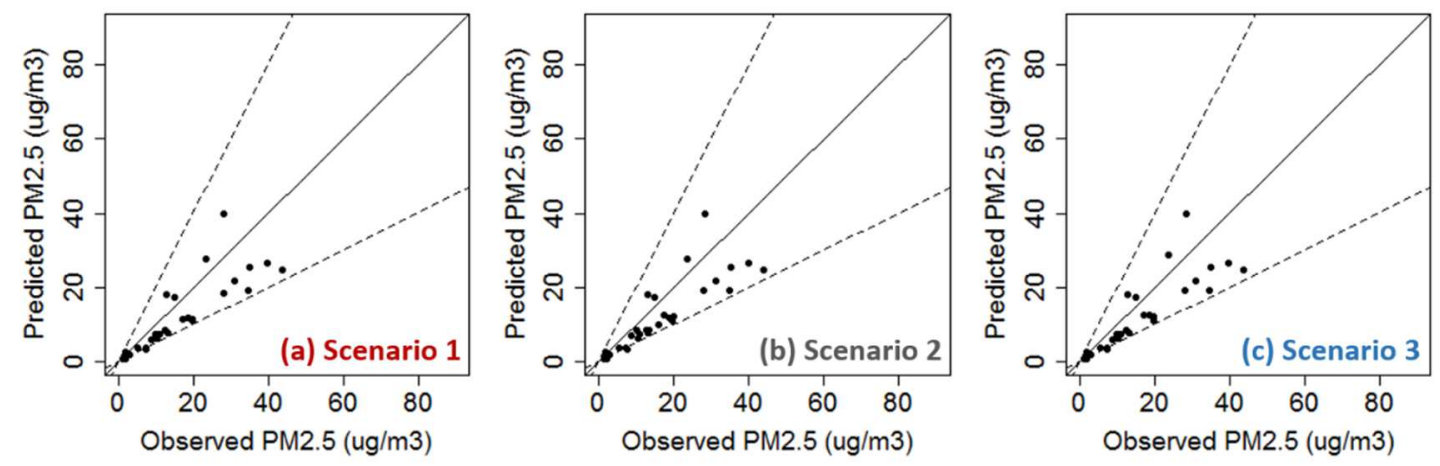

Figure 4.5 Predicted versus observed $\mathrm{PM}_{2.5}$ for winter peak hours and receptor 1 (SW corner) only, (a) Scenario 1, (b) Scenario 2, and (c) Scenario 3 model setup. 

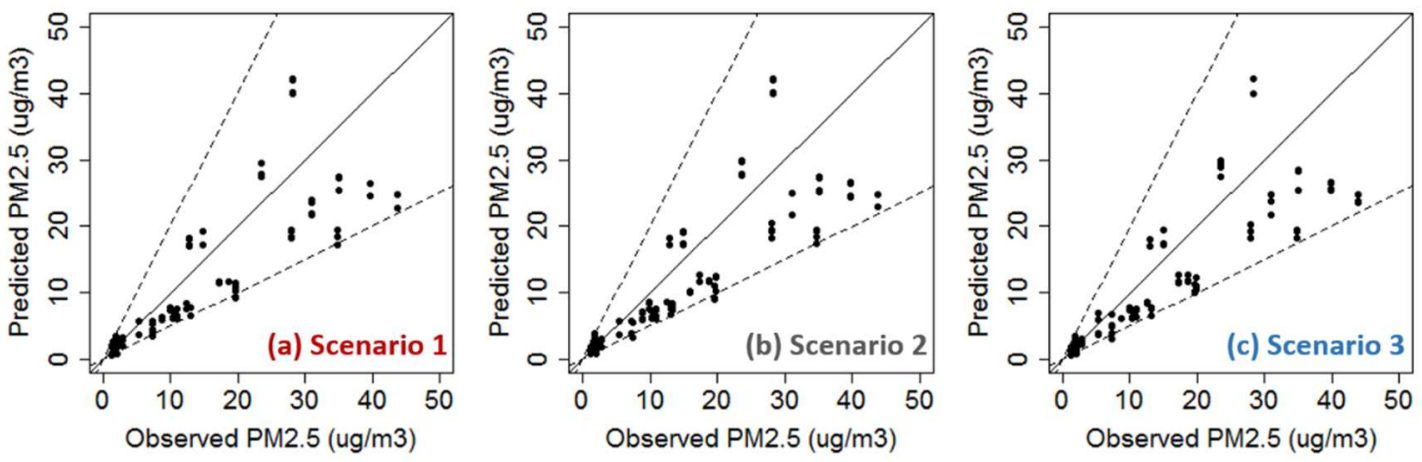

Figure 4.6 Predicted versus observed $\mathrm{PM}_{2.5}$ for winter peak hours and all four corner receptors, (a) Scenario 1, (b) Scenario 2, and (c) Scenario 3 model setup.
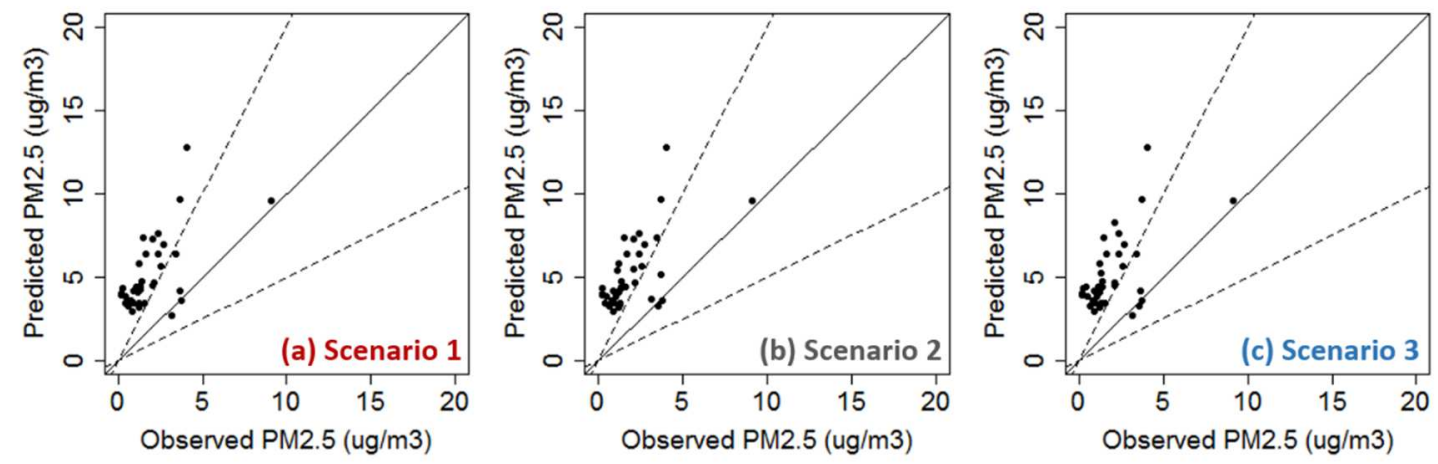

Figure 4.7 Predicted versus observed $\mathrm{PM}_{2.5}$ for summer peak hours and receptor 1 (SW corner) only, (a) Scenario 1, (b) Scenario 2, and (c) Scenario 3 model setup.
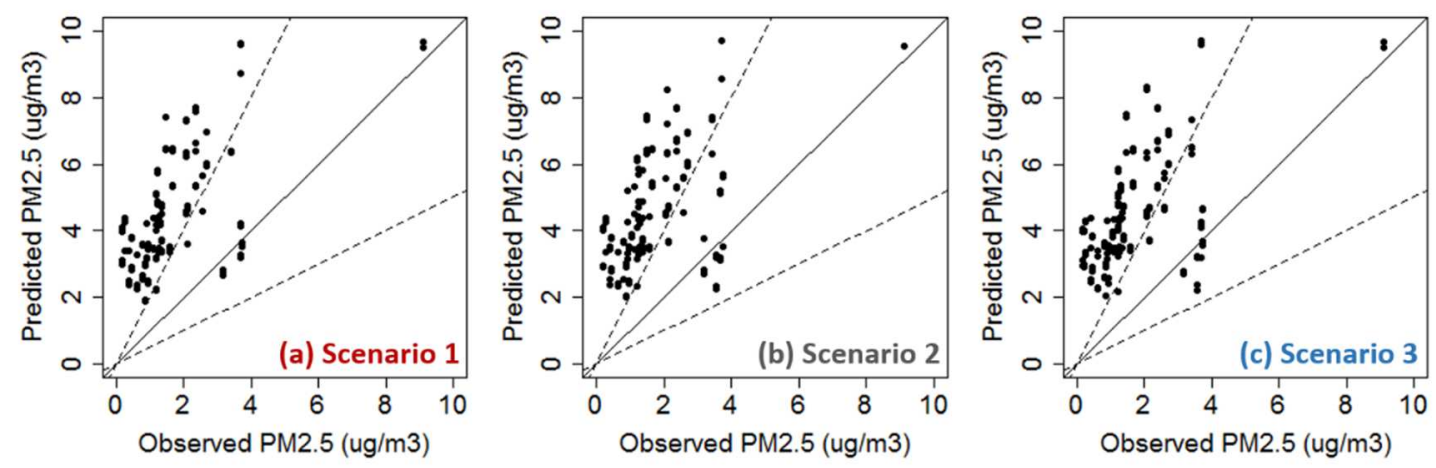

Figure 4.8 Predicted versus observed $\mathrm{PM}_{2.5}$ for summer peak hours and all four corner receptors, (a) Scenario 1, (b) Scenario 2, and (c) Scenario 3 model setup. 
Table 4.5 Percentage of points falling within the factor of two envelope for all 3 scenarios and winter time periods.

\begin{tabular}{|l|l|c|c|c|}
\hline \multicolumn{1}{|c|}{ Winter } & \multicolumn{1}{|c|}{ Datasets } & Percentage of Points Within Factor of 2 Envelope \\
\hline \multirow{2}{*}{ Scenario 1 } & & $8 a m$ & 5 pm & All Hours \\
\hline \multirow{2}{*}{ Scenario 2 } & Receptor 1 Only & 86 & 100 & 93 \\
\cline { 2 - 5 } & All Receptors & 93 & 95 & 94 \\
\hline \multirow{2}{*}{ Scenario 3 } & Receptor 1 Only & 87 & 100 & 94 \\
\cline { 2 - 5 } & All Receptors & 93 & 94 & 94 \\
\hline & Receptor 1 Only & 86 & 100 & 93 \\
\cline { 2 - 5 } & All Receptors & 93 & 97 & 95 \\
\hline
\end{tabular}

Table 4.6 Percentage of points falling within the factor of two envelope for all 3 scenarios and summer time periods.

\begin{tabular}{|l|l|c|c|c|}
\hline \multicolumn{1}{|c|}{ Summer } & \multicolumn{1}{|c|}{ Datasets } & Percentage of Points Within Factor of 2 Envelope \\
\hline \multirow{2}{*}{ Scenario 1 } & & $8 \mathrm{am}$ & $5 \mathrm{pm}$ & All Hours \\
\hline \multirow{2}{*}{ Scenario 2 } & Receptor 1 Only & 21 & 6 & 14 \\
\cline { 2 - 5 } & All Receptors & 24 & 11 & 18 \\
\hline \multirow{2}{*}{ Scenario 3 } & Receptor 1 Only & 19 & 6 & 13 \\
\cline { 2 - 5 } & All Receptors & 23 & 11 & 17 \\
\cline { 2 - 5 } & Receptor 1 Only & 24 & 6 & 15 \\
\cline { 2 - 5 } & All Receptors & 25 & 11 & 19 \\
\hline
\end{tabular}

While being within the factor of two envelope, the majority of winter $\mathrm{PM}_{2.5}$ predictions were below the 1:1 line showing a tendency to be biased low. Summer modeled concentrations are biased high compared to observations. Chen et al. (2009) showed a similar pattern in CAL3QHC results for a site with observations made very close to the roadside and the model overpredicted for low concentrations and underpredicted for high concentrations ${ }^{104}$. Observed $\mathrm{PM}_{2.5}$ is higher in the winter 
compared to summer explaining the large seasonal difference in model performance. $\mathrm{PM}_{2.5}$ observations also show that the $\mathrm{PM}_{2.5}$ contribution from traffic is low which is supported by the model results when wind speeds are greater than $1 \mathrm{~m} / \mathrm{s}$. This low contribution from traffic makes model performance heavily dependent on the background concentration data used to add to predicted concentrations. Chen et al. (2009) attributes the poor performance possibly to the close proximity of the receptor to the road segment and a street canyon effect resulting in complex meteorology. Both of these explanations support that $\mathrm{CAL} 3 \mathrm{QHC}$ is not suitable for estimating $\mathrm{PM}_{2.5}$ levels at locations where stable state cannot be achieved ${ }^{104}$. For urban arterials and modeling impacts in the near road-road environment where urban residents are waiting for transit, walking, and/or biking, these results do not support CAL3QHC as an appropriate model.

For the near-road site in Chen et al. (2009), there were 253 hours assessed spanning across two years, but no seasonal component or difference in trends were presented. Winter modeled periods presented here would have lower boundary layer heights compared to summer modeled periods and increased cloud cover which may introduce more variability in meteorological conditions than the stability classes used by CAL3QHC can capture. AERMOD, the other EPA approved model for $\mathrm{PM}_{2.5}$ hot-spot analysis, incorporates the effects of the planetary boundary layer based on more recent atmospheric science ${ }^{128,129}$. Running similar simulations as presented in this study using AERMOD is proposed to help further resolve the difference in performance with the range in measured $\mathrm{PM}_{2.5}$ observations. Additionally, EPA has proposed changes to Appendix $\mathrm{W}$ to list only AERMOD as the recommended model for transportation 
conformity analyses with a final decision to come in 2016. Understanding how AERMOD performs compared to the various scenarios presented here are important as model research and development may become more focused only on AERMOD and practitioners will need to switch modeling processes.

Using the factor of two criteria presented in Tables 4.5 and 4.6, model performance did not vary much based on the three input scenarios. Meteorological data used for each scenario was the same. These results demonstrate that the meteorology is the dominant factor in model performance for this study intersection and the varying emissions, traffic, and signal inputs only altered results slightly. Idling emissions are found to be the lowest in empirical on-road emissions measurements compared to acceleration and deceleration so the small impact of idling emissions shown here between scenarios 1 and 3 is not unsupported ${ }^{25}$. The study intersection during peak periods like many urban arterials also has very consistent traffic volumes so the range in variation that did exist between using real-world hourly volumes in Scenario 1 and static traffic surveys in scenario 2 was not enough to show a strong effect on predicted $\mathrm{PM}_{2.5}$ concentrations. These results can help support modeling or research projects using CAL3QHC when detailed signal and traffic data is not available.

\subsubsection{PNC Emission Factors}

The morning 8am peak hour and evening 5pm peak hour periods on the days when PNC measurements occurred were simulated using CAL3QHC. Predicted particle 
concentrations were matched to observed PNC measurements and that ratio was used to back calculate a particle emission factor for each time period. Figure 4.9 shows the distributions of particle number emission factors (particles $/ \mathrm{km}$ ) derived for each time period modeled. Table 4.7 compares the Portland emission factors with other field studies that used a variety of empirical on-road and modeling techniques to determine particle number emission factors. The emission factors from other studies in Table 4.7 are from urban roadways with the exception of Kittelson et al. (2004) which used measurements from a highway, but is also the only other U.S. study with field derived particle number emission factors.

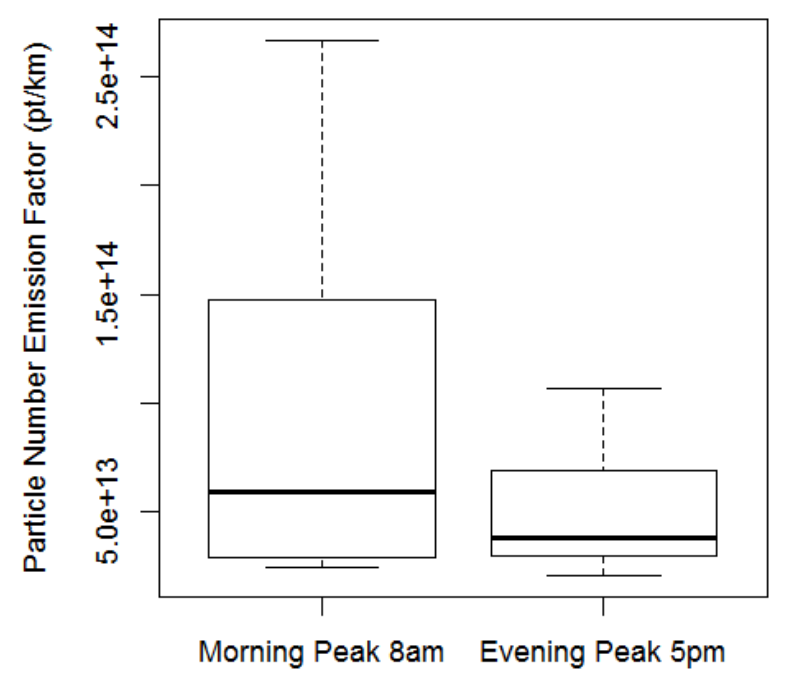

Figure 4.9 CAL3QHC derived particle emission factors for morning and evening peak hours when PNC measurements occurred.

The range of particle number emission factors for this study are within the ranges found in the literature (Figure 4.7). Portland mean particle number emission factors are 
very comparable to LDV emission factors derived from urban roads with lower speeds as found by Jones and Harrison (2006) $)^{130}$ and Imhof et al. (2005) ${ }^{131}$. Morawska et al (2005) found diesel specific particle number emission factors to be an order of magnitude higher than petrol only particle number emission factors for an urban road with stop and start traffic. The Portland mean particle number emission factors match well to the petrol emission factor values in stop and start conditions found by Morawska et al. (2005) while the diesel specific emission factor matches closer to the $95^{\text {th }}$ percentile emission factors found in Portland. The large difference in range in Portland particle number emission factors between the morning and evening could possibly be due to a difference in traffic fleet composition across these two time periods. Additionally, the CAL3QHC modeling is not taking into account any transformation processes such as dilution, nucleation, coagulation, condensation, evaporation, dry and wet deposition or complex flow and mixing characteristics as some aerosol specific dispersion models can ${ }^{118}$. However, this method of combining roadside measurements with CAL3QHC did produce credible particle number emission factors which can be used as starting points to estimate total emissions for a major urban arterial and could be extended to other types of roadways to help build an initial emission inventory by road type. 
Table 4.7 Comparison of urban roadway particle number emission factors from field studies.

\begin{tabular}{|c|c|c|c|c|}
\hline Study & Location & Road Description & $\begin{array}{c}\text { Particle Number } \\
\text { Emission Factor } \\
\text { particles } / \mathrm{km}\end{array}$ & $5^{\text {th }}-95^{\text {th }}$ percentiles \\
\hline This study & $\begin{array}{l}\text { Portland, } \\
\text { OR }\end{array}$ & $\begin{array}{l}\text { Major urban arterial } \\
\text { Morning median speeds } 32-45 \\
\text { kph } \\
\text { Evening median speeds } 23-42 \\
\text { kph }\end{array}$ & $\begin{array}{l}7.9 \times 10^{13} \text { (all runs) } \\
9.9 \times 10^{13} \text { (morning) } \\
5.7 \times 10^{13} \text { (evening) }\end{array}$ & $\begin{array}{l}2.3 \times 10^{13}-24 \times 10^{13} \\
2.5 \times 10^{13}-27 \times 10^{13} \\
2.2 \times 10^{13}-13 \times 10^{13}\end{array}$ \\
\hline $\begin{array}{l}\text { Wang et al. } \\
2010^{65}\end{array}$ & Copenhagen & Urban road & $\begin{array}{l}18.7 \times 10^{13} \text { (mixed } \\
\text { traffic) } \\
10.1 \times 10^{13}(\mathrm{LDV}) \\
220 \times 10^{13}(\mathrm{HDV})\end{array}$ & \\
\hline $\begin{array}{l}\text { Keogh et } \\
\text { al. } 2009^{117}\end{array}$ & $\begin{array}{l}\text { Queensland, } \\
\text { Australia }\end{array}$ & Mix of urban roads & $\begin{array}{l}36.3 \times 10^{13}(\mathrm{LDV}) \\
650 \times 10^{13}(\mathrm{HDV})\end{array}$ & $\begin{array}{l}98 \times 10^{13} \text { (upper } 95 \% \text { CI bound) } \\
601-698 \times 10^{13}(95 \% \text { CI } \\
\text { bounds) }\end{array}$ \\
\hline $\begin{array}{l}\text { Jones and } \\
\text { Harrison } \\
2006^{130}\end{array}$ & London & Urban road, speeds $<50 \mathrm{kph}$ & $\begin{array}{l}5.84 \times 10^{13}(\mathrm{LDV}) \\
6.36 \times 10^{13}(\mathrm{HDV})\end{array}$ & \\
\hline
\end{tabular}




\begin{tabular}{|c|c|c|c|c|}
\hline $\begin{array}{l}\text { Imhof et al. } \\
2005^{131}\end{array}$ & Switzerland & Urban road, $50 \mathrm{kph}$ & $\begin{array}{l}8 \times 10^{13}(\mathrm{LDV}) \\
550 \times 10^{13}(\mathrm{HDV})\end{array}$ & \\
\hline $\begin{array}{l}\text { Morawska } \\
\text { et al. } 2005 \\
132\end{array}$ & $\begin{array}{l}\text { Brisbane, } \\
\text { Australia }\end{array}$ & $\begin{array}{l}\text { Urban road with stop-start } \\
\text { traffic }\end{array}$ & $\begin{array}{l}2.18 \times 10^{13} \text { (petrol) } \\
20.4 \times 10^{13} \text { (diesel) }\end{array}$ & \\
\hline $\begin{array}{l}\text { Kittelson et } \\
\text { al. } 2004^{133}\end{array}$ & $\begin{array}{l}\text { Minneapolis, } \\
\text { Minnesota }\end{array}$ & $\begin{array}{l}\text { Highway, gasoline dominated } \\
\text { fleet }\end{array}$ & $19 \times 10^{13}$ (minimum) & $99 \times 10^{13}$ (maximum) \\
\hline
\end{tabular}




\subsection{Conclusion}

When compared with roadside $\mathrm{PM}_{2.5}$ observations, CAL3QHC performed well in predicting $\mathrm{PM}_{2.5}$ concentrations for winter peak traffic periods and poorly in predicting $\mathrm{PM}_{2.5}$ concentrations for summer peak traffic periods using the factor of two criteria. Despite general agreement between winter $\mathrm{PM}_{2.5}$ predictions and observations, predictions are biased low when observations are high and summer predictions are biased high when observed concentrations are lower. These performance results are similar to other studies with roadside measurements and hence a model receptor occurring very close to the roadway. In order to understand the seasonal differences and biases further, a comparison with AERMOD is recommended. AERMOD is also a Gaussian distribution model but accounts for planetary boundary layer effects which do increase variance in $\mathrm{PM}_{2.5}$ observations during the winter season.

$\mathrm{PM}_{2.5}$ concentrations were modeled using three separate input scenarios, one with hourly emissions, volume, signal, and meteorology data to use with the queuing algorithm. The second scenario used default signal values and static traffic survey data. The third scenario used hourly volumes, emissions, and meteorology data but no queuing algorithm or traffic signal inputs were used. For both winter and summer periods, there were negligible differences in performance across the three scenarios. These results help support modeling or research projects using CAL3QHC when detailed signal and traffic data is not available.

Lastly, CAL3QHC was used along with roadside PNC measurements to back calculate PNC emission factors for a mixed fleet and major arterial roadway in the U.S. 
These modeled particle number emission factors are comparable with particle number emission factors calculated for other urban roadways during periods with slower traffic speeds and stop and go traffic patterns. The majority of the emission factors calculated from field studies have been done so for non U.S. roadways. The values produced here are a starting place to estimate total particle number emissions for arterial corridors and emission inventories needed in order to further characterize particle number concentrations from traffic emissions for U.S roadways. 
Chapter 5 Implications and Future Directions

The integration of roadside air quality and traffic-related data from a major urban arterial in Portland, OR has led various findings that help improve the roadside environment in terms of exposure assessment and traffic management through the analyses presented in chapters $2-4$. Seasonal and diurnal characterizations demonstrated that morning time periods are a more consistent input throughout the year for modeling transportation and air quality impacts. Modeling projects focusing on evening periods only because traffic volumes are higher may be overestimating or underestimating exposure concentrations depending on the time of the year. Using traffic volumes as a proxy for exposure was demonstrated to be only reliable for annual mean exposures but not for 15 minute aggregated data, showing this method can capture chronic but not acute exposures such as experienced by urban road users. The results presented here can next be used in combination with health endpoint monitoring and modeling to improve understanding of the impacts of short, peak pollutant concentrations on health. Additionally, exposure questions such as understanding the tradeoffs between increased NOx concentrations versus a shorter time for a pedestrian spent waiting at the intersection can be explored.

Lessons learned from designing, building, and maintaining a roadside air quality monitoring station in a traffic signal cabinet are being directly applied to the deployment of a second arterial air quality monitoring station in Portland, OR. These two monitoring stations are integral pieces of an on-going design of a spatially distributed network of air quality and meteorological measurements. These two stations as not only important data 
collection sites but also essential reference sites when paired with more low-cost and moderately priced air quality sensors to help improve data quality and data usefulness for such sensors.

As cities, including Portland, OR, continue to embrace the technology and planning ideas under the emerging topic of Smart Cities, which includes increased sensor infrastructure to help better quantify and evaluate system operations, methods for data integration will continue to be needed. This work has directly informed and identified additional research and design needs for building an integrated network of air quality, meteorological, and traffic data system. Such data integration has to combine varying levels of data quality control procedures and feedback loops to maintain data quality and produce integrated data streams useful to researchers, modelers, urban planners, and transportation engineers.

A direct use of such integrated datasets and increased monitoring will be to continue evaluation of transportation management and operations strategies. The matching method presented in chapter 3 will be used for future assessments of understanding the impact of freight priority signaling and improved transit signal priority on roadside NOx and black carbon concentrations. This method will also be combined with increased spatial measurements of traffic-related pollutants to help understand longterm trends of pollutant concentrations and evaluate the impact of changes in fleet composition such as increased mode share of electric vehicles and even connected or autonomous vehicles which are being incentivized in future city plans. These evaluations are important for providing baselines, understanding how to decrease roadside exposures 
for urban residents and to provide feedback on actual decreases being achieved in terms of greenhouse gas emission levels from the transportation network. 


\section{References}

1. United, N. World Urbanization Prospects, the 2014 Revision. (2014).

2. Schneider, a. \& Woodcock, C. E. Compact, Dispersed, Fragmented, Extensive? A Comparison of Urban Growth in Twenty-five Global Cities using Remotely Sensed Data, Pattern Metrics and Census Information. Urban Stud. 45, 659-692 (2008).

3. 2010 Census Special Reports, Patterns of Metropolitan and Micropolitan Population Change : 2000 to 2010. (2012).

4. Brugge, D., Durant, J. L. \& Rioux, C. Near-highway pollutants in motor vehicle exhaust: a review of epidemiologic evidence of cardiac and pulmonary health risks. Environ. Health 6, 23 (2007).

5. Karner, A. a, Eisinger, D. S. \& Niemeier, D. a. Near-roadway air quality: synthesizing the findings from real-world data. Environ. Sci. Technol. 44, 5334-44 (2010).

6. Zhou, Y. \& Levy, J. I. Factors influencing the spatial extent of mobile source air pollution impacts: a meta-analysis. BMC Public Health 7, 89 (2007).

7. Rao, M., George, L. A., Rosenstiel, T. N., Shandas, V. \& Dinno, A. Assessing the relationship among urban trees, nitrogen dioxide, and respiratory health. Environ. Pollut. 194, 96-104 (2014).

8. Health Effects Institute. Traffic-Related Air Pollution: A Critical Review of the Literature on Emissions, Exposure, and Health Effects A Special Report of the HEI Panel on the Health Effects of Traffic-Related Air Pollution, Special Report 17. Crit. Rev. (2010).

9. Kim, J. J. et al. Residential traffic and children's respiratory health. Environ. Health Perspect. 116, 1274-9 (2008).

10. Peters, A. et al. Exposure to Traffic and the Onset of Myocardial Infarction. $N$. Engl. J. Med. 351, 1721-1730 (2004).

11. Peters, A. et al. Triggering of acute myocardial infarction by different means of transportation. Eur. J. Prev. Cardiol. 20, 750-8 (2013).

12. McCreanor, J. et al. Respiratory Effects of Exposure to Diesel Traffic in Persons with Asthma. N. Engl. J. Med. 357, 2348-2358 (2007). 
13. CFR. Primary National Ambient Air Quality Standards for Nitrogen Dioxide; Final Rule. 1-65 (2010).

14. Watkins, N. \& Baldauf, R. Near-road NO2 Monitoring Technical Assistance Document. (2012).

15. NCDOT. Functional Classification System. (1997).

16. Kendrick, C. M. et al. Impact of Bicycle Lane Characteristics on Exposure of Bicyclists to Traffic-Related Particulate Matter. Transp. Res. Rec. J. Transp. Res. Board 2247, 24-32 (2011).

17. Thai, A., McKendry, I. \& Brauer, M. Particulate matter exposure along designated bicycle routes in Vancouver, British Columbia. Sci. Total Environ. 405, 26-35 (2008).

18. Kaur, S., Nieuwenhuijsen, M. \& Colvile, R. Personal exposure of street canyon intersection users to PM2.5, ultrafine particle counts and carbon monoxide in Central London, UK. Atmos. Environ. 39, 3629-3641 (2005).

19. Kaur, S., Nieuwenhuijsen, M. J. \& Colvile, R. N. Fine particulate matter and carbon monoxide exposure concentrations in urban street transport microenvironments. Atmos. Environ. 41, 4781-4810 (2007).

20. Kaur, S. \& Nieuwenhuijsen, M. J. Determinants of Personal Exposure to PM 2 . 5, Ultrafine Particle Counts, and CO in a Transport Microenvironment. Environ. Sci. Technol. 43, 4737-4743 (2009).

21. McNabola, a., Broderick, B. M. \& Gill, L. W. Relative exposure to fine particulate matter and VOCs between transport microenvironments in Dublin: Personal exposure and uptake. Atmos. Environ. 42, 6496-6512 (2008).

22. Bigazzi, A. Y. \& Figliozzi, M. a. Review of Urban Bicyclists' Intake and Uptake of Traffic-Related Air Pollution. Transp. Rev. 34, 221-245 (2014).

23. Transportatiion, T. S. on H. and. TRB Task Force on Arterials and Public Health. $1-4$ (2014).

24. President's Council of Advisors on Science and Technology. Technology and the Future of Cities. (2016).

25. Unal, A., Rouphail, N. M. \& Frey, H. C. Effect of Arterial Signalization and Level of Service on Measured Vehicle Emissions. Transp. Res. Rec. J. Transp. Res.

Board 1842, 47-56 (2003). 
26. Stathopoulos, F. G. \& Noland, R. B. Induced Travel and Emissions from Traffic Flow Improvement Projects. Transp. Res. Rec. J. Transp. Res. Board 1842, 57-63 (2003).

27. De Coensel, B., Can, a., Degraeuwe, B., De Vlieger, I. \& Botteldooren, D. Effects of traffic signal coordination on noise and air pollutant emissions. Environ. Model. Softw. 35, 74-83 (2012).

28. Stevanovic, A., Stevanovic, J., Zhang, K. \& Batterman, S. Optimizing Traffic Control to Reduce Fuel Consumption and Vehicular Emissions. Transp. Res. Rec. J. Transp. Res. Board 2128, 105-113 (2009).

29. Fruin, S., Westerdahl, D., Sax, T., Sioutas, C. \& Fine, P. M. Measurements and predictors of on-road ultrafine particle concentrations and associated pollutants in Los Angeles. Atmos. Environ. 42, 207-219 (2008).

30. Westerdahl, D., Fruin, S., Sax, T., Fine, P. M. \& Sioutas, C. Mobile platform measurements of ultrafine particles and associated pollutant concentrations on freeways and residential streets in Los Angeles. Atmos. Environ. 39, 3597-3610 (2005).

31. Mavroidis, I. \& Ilia, M. Trends of NOx, NO2 and $\mathrm{O} 3$ concentrations at three different types of air quality monitoring stations in Athens, Greece. Atmos. Environ. 63, 135-147 (2012).

32. Charron, A. \& Harrison, R. M. Primary particle formation from vehicle emissions during exhaust dilution in the roadside atmosphere. Atmos. Environ. 37, 41094119 (2003).

33. Harrison, R. M., Jones, M. \& Collins, G. Measurements of the physical properties of particles in the urban atmosphere. Atmos. Environ. 33, 309-321 (1999).

34. Harrison, R. M. \& Jones, A. M. Multisite study of particle number concentrations in urban air. Environ. Sci. Technol. 39, 6063-70 (2005).

35. Arnold, S. J. et al. Introduction to the DAPPLE Air Pollution Project. Sci. Total Environ. 332, 139-53 (2004).

36. Colvile, R. N. et al. Sustainable development of urban transport systems and human exposure to air pollution. Sci. Total Environ. 334-335, 481-7 (2004).

37. EPA. Near Roadway Research. at $<$ http://www.epa.gov/airscience/airhighwayresearch.htm> 
38. Kimbrough, S., Shores. Richard C. \& Whitaker, D. A. FHWA and EPA National Near-Road Study, Detroit, MI Report No. DTFH61-07-X-30015. (2013).

39. Zhu, Y., Hinds, W. C., Kim, S. \& Sioutas, C. Concentration and Size Distribution of Ultrafine Particles Near a Major Highway. J. Air Waste Manage. Assoc. 52, 1032-1042 (2002).=

40. Zhu, Y., Hinds, W. C., Kim, S., Shen, S. \& Sioutas, C. Study of ultrafine particles near a major highway with heavy-duty diesel traffic. Atmos. Environ. 36, 43234335 (2002).

41. Zhu, Y., Hinds, W. C., Shen, S. \& Sioutas, C. Seasonal Trends of Concentration and Size Distribution of Ultrafine Particles Near Major Highways in Los Angeles. Aerosol Sci. Technol. 38, 5-13 (2004).

42. Zhang, K. M., Wexler, A. S., Zhu, Y. F., Hinds, W. C. \& Sioutas, C. Evolution of particle number distribution near roadways. Part II: the 'Road-to-Ambient' process. Atmos. Environ. 38, 6655-6665 (2004).

43. Zhu, Y., Kuhn, T., Mayo, P. \& Hinds, W. C. Comparison of daytime and nighttime concentration profiles and size distributions of ultrafine particles near a major highway. Environ. Sci. Technol. 40, 2531-6 (2006).

44. Zhu, Y. et al. Air pollutant concentrations near three Texas roadways, Part I: Ultrafine particles. Atmos. Environ. 43, 4513-4522 (2009).

45. Clements, A. L. et al. Air pollutant concentrations near three Texas roadways, part II: Chemical characterization and transformation of pollutants. Atmos. Environ. 43, 4523-4534 (2009).

46. Richmond-Bryant, J. et al. The Brooklyn traffic real-time ambient pollutant penetration and environmental dispersion (B-TRAPPED) field study methodology. J. Environ. Monit. 11, 2122-35 (2009).

47. Hahn, I., Wiener, R. W., Richmond-Bryant, J., Brixey, L. a \& Henkle, S. W. Overview of the Brooklyn traffic real-time ambient pollutant penetration and environmental dispersion (B-TRAPPED) study: theoretical background and model for design of field experiments. J. Environ. Monit. 11, 2115-21 (2009).

48. Heist, D. K. et al. The effect of a tall tower on flow and dispersion through a model urban neighborhood: part 1. Flow characteristics. J. Environ. Monit. 11, 2163-70 (2009). 
49. Brixey, L. a et al. The effect of a tall tower on flow and dispersion through a model urban neighborhood: part 2. Pollutant dispersion. J. Environ. Monit. 11, 2171-9 (2009).

50. Kendrick, C. M., Koonce, P. \& George, L. A. . Diurnal and seasonal variations of NO, NO2 and PM2.5 mass as a function of traffic volumes alongside an urban arterial. Atmos. Environ. 122, 133-141 (2015).

51. Adar, S. D. \& Kaufman, J. D. Cardiovascular disease and air pollutants: evaluating and improving epidemiological data implicating traffic exposure. Inhal. Toxicol. 19 Suppl 1, 135-49 (2007).

52. Tiwary, A., Robins, A., Namdeo, A. \& Bell, M. Air flow and concentration fields at urban road intersections for improved understanding of personal exposure. Environ. Int. 37, 1005-18 (2011).

53. De Nazelle, A. et al. Improving health through policies that promote active travel: a review of evidence to support integrated health impact assessment. Environ. Int. 37, 766-77 (2011).

54. Hoek, G. et al. A review of land-use regression models to assess spatial variation of outdoor air pollution. Atmos. Environ. 42, 7561-7578 (2008).

55. PortlandMaps An Information Service by The City of Portland. at $<$ https://www.portlandmaps.com/>

56. Bike Barometer: Portland Hawthorne Bridge. at $<$ http://portland-hawthornebridge.visio-tools.com/>

57. Kendrick, C. M., Urowsky, D., Rotich, W., Koonce, P. \& George, L. Effect of Reducing Maximum Cycle Length on Roadside Air Quality and Travel Times on a Corridor in Portland, OR. in Transp. Res. Board 93rd Annu. Meet. Compend. Pap. 14-2779 (2014).

58. George, L. A., Parra, J. \& Sitbon, P. Horizons- Portland Area Real-Time and Archived Air Quality and Meteorological Data. (2005).

59. Zhu, Y. et al. Comparing gravimetric and real-time sampling of $\operatorname{PM}(2.5)$ concentrations inside truck cabins. J. Occup. Environ. Hyg. 8, 662-72 (2011).

60. Team, R. C. R: A language and environment for statistical computing. (2013).

61. Sarkar, D. Lattice: Multivariate Data Visualization with R. (2008). 
62. Koenker, R. quantreg: Quantile Regression. (2015).

63. Thoma, E., Shores, R., Isakov, V. \& Baldauf, R. Characterization of Near-Road Pollutant Gradients Using Path-Integrated Optical Remote Sensing. J. Air Waste Manage. Assoc. 58, 879-890 (2008).

64. Baldauf, R. et al. Traffic and Meteorological Impacts on Near-Road Air Quality: Summary of Methods and Trends from the Raleigh Near-Road Study. J. Air Waste Manage. Assoc. 58, 865-878 (2008).

65. Wang, F. et al. Particle number, particle mass and NOx emission factors at a highway and an urban street in Copenhagen. Atmos. Chem. Phys. 10, 2745-2764 (2010).

66. Pérez, N. et al. Variability of Particle Number, Black Carbon, and PM 10, PM 2.5 , and PM 1 Levels and Speciation: Influence of Road Traffic Emissions on Urban Air Quality. Aerosol Sci. Technol. 44, 487-499 (2010).

67. Jamriska, M., Morawska, L. \& Mergersen, K. The effect of temperature and humidity on size segregated traffic exhaust particle emissions. Atmos. Environ. 42, 2369-2382 (2008).

68. Monn, C. Exposure assessment of air pollutants : a review on spatial heterogeneity and indoor/outdoor/personal exposure to suspended particulate matter, nitrogen dioxide and ozone. Atmos. Environ. 35, 1-32 (2001).

69. Martuzevicius, D. et al. Spatial and temporal variations of PM2.5 concentration and composition throughout an urban area with high freeway density - the Greater Cincinnati study. Atmos. Environ. 38, 1091-1105 (2004).

70. Davino, C., Furno, M. \& Vistocco, D. Quantile Regression: Theory and Applications. (John Wiley \& Sons, 2013).

71. Agus, E. L. et al. Factors influencing particle number concentrations, size distributions and modal parameters at a roof-level and roadside site in Leicester, UK. Sci. Total Environ. 386, 65-82 (2007).

72. Carslaw, D. C. Evidence of an increasing NO/NO emissions ratio from road traffic emissions. Atmos. Environ. 39, 4793-4802 (2005).

73. Bigi, A. \& Harrison, R. M. Analysis of the air pollution climate at a central urban background site. Atmos. Environ. 44, 2004-2012 (2010). 
74. Weiner, E. Urban Transportation Planning in the United States History, Policy, and Practice. (Springer, 2008).

75. Coelho, M. C., Farias, T. L. \& Rouphail, N. M. Impact of speed control traffic signals on pollutant emissions. Transp. Res. Part D Transp. Environ. 10, 323-340 (2005).

76. Madireddy, M. et al. Assessment of the impact of speed limit reduction and traffic signal coordination on vehicle emissions using an integrated approach. Transp. Res. Part D 16, 504-508 (2011).

77. Papson, A., Hartley, S. \& Kuo, K.-L. Analysis of Emissions at Congested and Uncongested Intersections with Motor Vehicle Emission Simulation 2010. Transp. Res. Rec. J. Transp. Res. Board 2270, 124-131 (2012).

78. Rakha, H., Aerde, M. Van, Ahn, K. \& Trani, A. A. Requirements for Evaluating Traffic Signal Control Impacts on Energy and Emissions Based on Instantaneous Speed and Acceleration Measurements. Transp. Res. Rec. 1738, (2000).

79. Rakha, H. \& Ahn, K. Integration Modeling Framework for Estimating Mobile Source Emissions. 183-193 (2004).

80. Chen, K. \& Yu, L. Microscopic Traffic-Emission Simulation and Case Study for Evaluation of Traffic Control Strategies. J. Transp. Syst. Eng. Inf. Technol. 7, 9399 (2007).

81. Alam, A., Ghafghazi, G. \& Hatzopoulou, M. Traffic Emissions and Air Quality Near Roads in Dense Urban Neighborhood. Transp. Res. Rec. J. Transp. Res. Board 2427, 83-92 (2014).

82. Zhang, Y. et al. Assessing Effect of Traffic Signal Control Strategies on Vehicle Emissions. J. Transp. Syst. Eng. Inf. Technol. 9, 150-155 (2009).

83. Hallmark, S. L., Wang, B., Mudgal, A. \& Isebrands, H. On-Road Evaluation of Emission Impacts of Roundabouts. Transp. Res. Rec. J. Transp. Res. Board 2265, 226-233 (2011).

84. Kim, K. H., Lee, S.-B., Woo, S. H. \& Bae, G.-N. NOx profile around a signalized intersection of busy roadway. Atmos. Environ. 97, 144-154 (2014).

85. Frey, H. C., Rouphail, N. M., Unal, A. \& Colyar, J. D. Emissions Reduction Through Better Traffic Management: An Empirical Evaluation Based Upon OnRoad Measurements. FHWY/NC/2002-001, Prep. by NC State Univ. NC Dep. Transp. Raleigh NC: 28, (2001). 
86. Ho, D. E., Imai, K., King, G. \& Stuart, E. a. Matching as nonparametric preprocessing for reducing model dependence in parametric causal inference. Polit. Anal. 15, 199-236 (2007).

87. Stuart, E. a. Matching methods for causal inference: A review and a look forward. Stat. Sci. 25, 1-21 (2010).

88. Rubin, D. B. Matched Sampling for Casual Effects. (Cambridge University Press, 2006).

89. Rosenbaum, P. R. \& Rubin, D. B. The central role of the propensity score in obervational studies for causal effects. Biometrika 70, 41-55 (1983).

90. Cochran, W. G. \& Rubin, D. B. Controlling Bias in Obsevational Studies: A Review. Indian J. Stat. 35, 417166 (1973).

91. Ho, D. E., Imai, K., King, G. \& Stuart, E. A. MatchIt: Nonparametric Preprocessing for Parametric Casual Inference. J. Stat. Softw. 42, 1-28 (2011).

92. Cochran, W. G. The effectiveness of adjustment by subclassification in removing bias in observational studies. Biometrics 24, 295-313 (1968).

93. King, G. \& Zeng, L. The dangers of extreme counterfactuals. Polit. Anal. 14, 131159 (2006).

94. Limpert, E., Stahel, W. A. \& Abbt, M. Log-normal Distributio ns across the Sciences: Keys and Clues. Bioscience 51, 341-352 (2001).

95. CFR. National Ambient Air Quality Standards for Pariculate Matter: Final Rule. 71, 61144-61233 (2006).

96. US EPA. Transportation Conformity Guidance for Quantitative Hot-spot Analyses in PM 2.5 and PM 10 Nonattainment and Maintenance Areas. (2015).

97. Benson, P. E. A review of the development and application of the CALINE3 and 4 Models. Atmos. Environ. 26, 379-390 (1992).

98. Heist, D. et al. Estimating near-road pollutant dispersion: A model intercomparison. Transp. Res. Part D Transp. Environ. 25, 93-105 (2013).

99. Coe, D. L., Eisinger, D. S., Prouty, J. D. \& Kear, T. USER ' S GUIDE FOR CL4 : A USER-FRIENDLY INTERFACE FOR THE CALINE 4 MODEL FOR TRANSPORTATION PROJECT IMPACT ASSESSMENTS. (1998). 
100. Sivacoumar, R. \& Thanasekaran, K. Comparison and Performance Evaluation of Models Used for Vehicular Pollution Prediction. J. Environ. Eng. 127, 524-530 (2001).

101. Levitin, J., Härkönen, J., Kukkonen, J. \& Nikmo, J. Evaluation of the CALINE4 and CAR-FMI models against measurements near a major road. Atmos. Environ. 39, 4439-4452 (2005).

102. Gokhale, S. \& Raokhande, N. Performance evaluation of air quality models for predicting PM10 and PM2.5 concentrations at urban traffic intersection during winter period. Sci. Total Environ. 394, 9-24 (2008).

103. EPA. User's Guide to CAL3QHC Version 2.0: A Modeling Methodology for Predicitng Pollutant Concentrations Near Roadway Intersections. (1995).

104. Chen, H., Bai, S., Eisinger, D., Niemeier, D. \& Claggett, M. Predicting Near-Road PM2.5 Concentrations. Transp. Res. Rec. J. Transp. Res. Board 2123, 26-37 (2009).

105. Gokhale, S. Traffic flow pattern and meteorology at two distinct urban junctions with impacts on air quality. Atmos. Environ. 45, 1830-1840 (2011).

106. Chen, H., Bai, S., Eisinger, D., Niemeier, D. \& Claggett, M. UC Davis-Caltrans Air Quality Project, Task Numbers $67 \&$ 80, Modeling Uncertainties and NearRoad PM2.5 : A Comparison of Caline4, CAL3QHC and Aermod. (2008).

107. Zhang, J. \& Morawska, L. Combustion sources of particles: 2. Emission factors and measurement methods. Chemosphere 49, 1059-1074 (2002).

108. Kittelson, D. B. Engines and nanoparticles: A review. J. Aerosol Sci. 29, 575-588 (1998).

109. Harrison, R. M. et al. Measurement of number, mass and size distribution of particles in the atmosphere. Philos. Trans. R. Soc. A Math. Phys. Eng. Sci. 358, 2567-2580 (2000).

110. Moller, P. et al. Air pollution, oxidative damage to DNA, and carcinogenesis. Cancer Lett. 266, 84-97 (2008).

111. Vinzents, P. S. et al. Personal exposure to ultrafine particles and oxidative DNA damage. Environ. Health Perspect. 113, 1485-1490 (2005).

112. Seaton, A., MacNee, W., Donaldson, K. \& Godden, D. Particulate air pollution and acute health effects. Lancet 345, 176-178 (1995). 
113. Li, N. et al. Ultrafine particulate pollutants induce oxidative stress and mitochondrial damage. Environ. Health Perspect. 111, 455-460 (2003).

114. Araujo, J. a. et al. Ambient particulate pollutants in the ultrafine range promote early atherosclerosis and systemic oxidative stress. Circ. Res. 102, 589-596 (2008).

115. Heal, M. R., Kumar, P. \& Harrison, R. M. Particles, air quality, policy and health. Chem. Soc. Rev. 41, 6606 (2012).

116. Kumar, P. et al. Ultrafine particles in cities. Environ. Int. 66, 1-10 (2014).

117. Keogh, D. U., Ferreira, L. \& Morawska, L. Development of a particle number and particle mass vehicle emissions inventory for an urban fleet. Environ. Model. Softw. 24, 1323-1331 (2009).

118. Kumar, P., Ketzel, M., Vardoulakis, S., Pirjola, L. \& Britter, R. Dynamics and dispersion modelling of nanoparticles from road traffic in the urban atmospheric environment-A review. J. Aerosol Sci. 42, 580-603 (2011).

119. Yura, E. A., Kear, T. \& Niemeier, D. Using CALINE dispersion to assess vehicular PM2.5 emissions. Atmos. Environ. 41, 8747-8757 (2007).

120. Lin, F.-B., Tseng, P.-Y. \& Su, C.-W. Variations in Queue Discharge Patterns and Their Implications in Analysis of Signalized Intersections. Transp. Res. Rec. 1883, 192-197 (2004).

121. Transportation Research Board. Highway Capacity Manual Volume 4: Applications Guide, Chapter 31 Signalized Intersections: Supplemental. (2010).

122. Wang, M.-H. \& Benekohal, R. (Ray) F. Analysis of Left-Turn Saturation Flow Rates and Capacity at Signalized Intersections. Transp. Res. Rec. J. Transp. Res. Board 2173, 96-104 (2010).

123. Metro. 2014 Regional Transportation Plan.

124. Metro. 2014 Regional Transportation Plan Technical Appendix. (2014).

125. Quayle, S. M., Koonce, P., DePencier, D. \& Bullock, D. M. Arterial Performance Measures with Media Access Control Readers. Transp. Res. Rec. J. Transp. Res. Board 2192, 185-193 (2011).

126. Pasquill, F. The estimation of the dispersion of windborne material. Meteorol. Mag. 90,33-49 (1961). 
127. Turner, B. D. Workbook of Atmospheric Dispersion Estimates. (Office of Air Programs Publication No. AP-26, 1969).

128. Lin, J. \& Vallamsundar, S. Transportation Conformity Particulate Matter HotSpot Air Quality Modeling, Research Report No. FHWA-ICT-13-024. (2013).

129. Cimorelli, A. J. et al. AERMOD : A Dispersion Model for Industrial Source Applications . Part I : General Model Formulation and Boundary Layer Characterization. J. Appl. Meteorol. 44, 682-693 (2005).

130. Jones, A. M. \& Harrison, R. M. Estimation of the emission factors of particle number and mass fractions from traffic at a site where mean vehicle speeds vary over short distances. Atmos. Environ. 40, 7125-7137 (2006).

131. Imhof, D. et al. Real-world emission factors of fine and ultrafine aerosol particles for different traffic situations in Switzerland. Environ. Sci. Technol. 39, 8341-50 (2005).

132. Morawska, L. et al. Quantification of particle number emission factors for motor vehicles from on-road measurements. Environ. Sci. Technol. 39, 9130-9139 (2005).

133. Kittelson, D. B., Watts, W. F. \& Johnson, J. P. Nanoparticle emissions on Minnesota highways. Atmos. Environ. 38, 9-19 (2004). 
A. Appendix A: Literature Review Tables of Near-Road Air Quality Studies

Table 0-1 Near-road air quality monitoring studies with at least one curbside or sidewalk location.

\begin{tabular}{|c|c|c|c|c|c|c|c|c|c|}
\hline $\begin{array}{c}\text { First Author } \\
\text { \& Year }\end{array}$ & Location & $\mathrm{NOx}$ & $\begin{array}{l}\text { PM } \\
\text { Mass }\end{array}$ & $\begin{array}{c}\text { PM } \\
\text { Number }\end{array}$ & $\begin{array}{c}\text { Roadway } \\
\text { Type }\end{array}$ & $\begin{array}{l}\text { Roadway } \\
\text { Descriptors }\end{array}$ & $\begin{array}{l}\text { Stuy } \\
\text { Length }\end{array}$ & $\begin{array}{l}\text { Traffic } \\
\text { Data }\end{array}$ & $\begin{array}{l}\text { Type of } \\
\text { traffic data }\end{array}$ \\
\hline $\begin{array}{l}\text { Kendrick et } \\
\text { al } 2015\end{array}$ & Portland, OR & Yes & Yes & Yes & $\begin{array}{l}\text { Major urban } \\
\text { arterial }\end{array}$ & $\begin{array}{l}2800 \mathrm{veh} / \mathrm{hour} \\
\text { for peak periods }\end{array}$ & $\begin{array}{l}1 \text { year \& } 6 \\
\text { months, } \\
\text { ongoing }\end{array}$ & Yes & $\begin{array}{l}\text { Traffic } \\
\text { volume, } \\
\text { degree of } \\
\text { saturation, } \\
\text { travel } \\
\text { times, } \\
\text { cycle } \\
\text { length }\end{array}$ \\
\hline $\begin{array}{l}\text { Mavroidis et } \\
\text { al } 2012\end{array}$ & $\begin{array}{l}\text { Athens, } \\
\text { Greece }\end{array}$ & Yes & & & $\begin{array}{l}\text { Major urban } \\
\text { arterial }\end{array}$ & $67,000 \mathrm{veh} /$ day & 25 years & No & \\
\hline $\begin{array}{l}\text { Pirjola et al } \\
2012\end{array}$ & $\begin{array}{l}\text { Helsinki, } \\
\text { Finland }\end{array}$ & Yes & Yes & & $\begin{array}{l}\text { Main urban } \\
\text { arterial }\end{array}$ & $40,000 \mathrm{veh} /$ day & 2.5 weeks & No & \\
\hline $\begin{array}{l}\text { Wang et al } \\
2010\end{array}$ & $\begin{array}{l}\text { Copenhagen, } \\
\text { Denmark }\end{array}$ & Yes & Yes & Yes & $\begin{array}{l}\text { Highway \& } \\
\text { busy urban } \\
\text { street }\end{array}$ & & 4 weeks & Yes & $\begin{array}{l}\text { Highway } \\
\text { only, } \\
\text { automatic } \\
\text { traffic } \\
\text { counts }\end{array}$ \\
\hline $\begin{array}{l}\text { Kumar et al } \\
2008 \mathrm{a}\end{array}$ & $\begin{array}{l}\text { Cambridge, } \\
\text { UK }\end{array}$ & & & Yes & $\begin{array}{l}\text { Urban street } \\
\text { canyon }\end{array}$ & $\begin{array}{l}\text { Two way traffic } \\
10 \mathrm{~m} \text { width, } 1\end{array}$ & 7 days & Yes & $\begin{array}{l}\text { Visual } \\
\text { traffic } \\
\text { counts \& }\end{array}$ \\
\hline
\end{tabular}




\begin{tabular}{|c|c|c|c|c|c|c|c|c|c|}
\hline & & & & & & $\begin{array}{l}\text { lane in each } \\
\text { direction }\end{array}$ & & & $\begin{array}{l}\text { compositio } \\
\mathrm{n}\end{array}$ \\
\hline $\begin{array}{l}\text { Kumar et al } \\
2008 \text { b }\end{array}$ & $\begin{array}{l}\text { Cambridge, } \\
\text { UK }\end{array}$ & & & Yes & $\begin{array}{l}\text { Urban street } \\
\text { canyon }\end{array}$ & $\begin{array}{l}\text { One lane of } \\
\text { traffic }(18 \mathrm{mph})\end{array}$ & 17 days & Yes & $\begin{array}{l}\text { Traffic } \\
\text { volumes } \\
\text { movement } \\
\text { sensitive } \\
\text { CCTV } \\
\text { camera }\end{array}$ \\
\hline $\begin{array}{l}\text { Jamriska et } \\
\text { al } 2008\end{array}$ & $\begin{array}{l}\text { Brisbane, } \\
\text { Australia }\end{array}$ & & & Yes & $\begin{array}{l}\text { Highway \& } \\
\text { Major urban } \\
\text { arterial }\end{array}$ & $\begin{array}{l}\text { Steady speed } \\
100 \mathrm{~km} / \mathrm{h} \& \max \\
\text { speed } 60 \mathrm{~km} / \mathrm{h}\end{array}$ & 5 months & Yes & $\begin{array}{l}\text { Traffic } \\
\text { flow rate \& } \\
\text { intermittent } \\
\text { compositio } \\
\text { n (video) }\end{array}$ \\
\hline $\begin{array}{l}\text { Agus et al } \\
2007\end{array}$ & $\begin{array}{l}\text { Leicester, } \\
\text { UK }\end{array}$ & Yes & & Yes & $\begin{array}{l}\text { Urban } \\
\text { arterial }\end{array}$ & $1100 \mathrm{veh} /$ hour & 4 weeks & Yes & $\begin{array}{l}\text { Traffic } \\
\text { volume \& } \\
\text { detector } \\
\text { occupancy } \\
\text { SCOOT } \\
\text { system, } \\
\text { piezo- } \\
\text { electric } \\
\text { loops }\end{array}$ \\
\hline $\begin{array}{l}\text { Charron et } \\
\text { al } 2003\end{array}$ & London, UK & Yes & Yes & Yes & $\begin{array}{l}\text { Major urban } \\
\text { arterial }\end{array}$ & $80,000 \mathrm{veh} /$ day & $\begin{array}{l}\text { Up to } 3 \\
\text { years }\end{array}$ & Yes & $\begin{array}{l}\text { Traffic } \\
\text { volume \& } \\
\text { compositio } \\
\text { n induction } \\
\text { loops }\end{array}$ \\
\hline
\end{tabular}




\begin{tabular}{|c|c|c|c|c|c|c|c|c|c|}
\hline $\begin{array}{l}\text { Ntziachristo } \\
\text { s et al } 2007 \\
\text { winter }\end{array}$ & $\begin{array}{l}\text { Los Angeles, } \\
\text { California }\end{array}$ & & Yes & Yes & $\begin{array}{l}\text { Freeway } \\
\text { (10m away) }\end{array}$ & $\begin{array}{l}150,000- \\
200,000 \\
\text { veh/day, up to } \\
25 \% \text { heavy duty }\end{array}$ & 2 months & Yes & $\begin{array}{l}\text { State DOT } \\
\text { (loops) and } \\
\text { manual and } \\
\text { videotaped } \\
\text { counts }\end{array}$ \\
\hline $\begin{array}{l}\text { Harrison et } \\
\text { al } 2005\end{array}$ & London, UK & & & Yes & $\begin{array}{l}\text { Major urban } \\
\text { arterial }\end{array}$ & $80,000 \mathrm{veh} /$ day & 3 years & No & \\
\hline $\begin{array}{l}\text { Namdeo and } \\
\text { Bell } 2005\end{array}$ & London, UK & Yes & Yes & & $\begin{array}{l}\text { Major urban } \\
\text { arterial }\end{array}$ & & 1 year & No & \\
\hline $\begin{array}{l}\text { Imhof et al } \\
2005\end{array}$ & $\begin{array}{l}\text { Zurich, } \\
\text { Switzerland }\end{array}$ & Yes & Yes & Yes & $\begin{array}{l}\text { Motorway } \\
\text { Highway } \\
\text { Signalized } \\
\text { urban road }\end{array}$ & $\begin{array}{l}62,000 \mathrm{veh} / \text { day } \\
25,000 \mathrm{veh} / \text { day } \\
22,000 \mathrm{veh} / \text { day } \\
\mathrm{w} / \text { stop and go } \\
\text { traffic }\end{array}$ & 12-60 days & Yes & $\begin{array}{l}\text { Traffic } \\
\text { counts, } \\
\text { vehicle } \\
\text { lengths } \\
\text { with } \\
\text { induction } \\
\text { loops \& } \\
\text { Optical } \\
\text { counter }\end{array}$ \\
\hline $\begin{array}{l}\text { Molnar et al } \\
2002\end{array}$ & $\begin{array}{l}\text { Gothenburg, } \\
\text { Sweden }\end{array}$ & & Yes & Yes & $\begin{array}{l}\text { Main } \\
\text { commuting } \\
\text { road }\end{array}$ & $\begin{array}{l}20,000 / 13,000 \\
\text { veh/day } \\
\text { weekday/weeke } \\
\text { nd }\end{array}$ & 3 weeks & No & \\
\hline $\begin{array}{l}\text { Lena et al } \\
2002\end{array}$ & $\begin{array}{l}\text { Hunts Point } \\
\text { (peninsula in } \\
\text { Bronx, NY) }\end{array}$ & & $\begin{array}{c}\text { Yes } \\
\text { (focus } \\
\text { on }\end{array}$ & & $\begin{array}{l}6 \text { different } \\
\text { intersections }\end{array}$ & $\begin{array}{l}155-340 \\
\text { cars/hour } \\
9-277 \\
\text { trucks/hours }\end{array}$ & $\begin{array}{l}11 \mathrm{hrs} / \text { day, } \\
3 \\
\text { days/week } \\
\text { for } 3 \text { weeks }\end{array}$ & Yes & $\begin{array}{l}\text { Manual } \\
\text { counts \& } \\
\text { compositio } \\
\mathrm{n}\end{array}$ \\
\hline
\end{tabular}




\begin{tabular}{|c|c|c|c|c|c|c|c|c|c|}
\hline & & & $\begin{array}{l}\text { compo } \\
\text { sition) }\end{array}$ & & & & & & \\
\hline $\begin{array}{l}\text { Lal et al } \\
2001\end{array}$ & $\begin{array}{l}\text { Mumbai, } \\
\text { India }\end{array}$ & Yes & & & $\begin{array}{l}\text { Major urban } \\
\text { arterial \& } \\
\text { intersection }\end{array}$ & $\begin{array}{l}300 \mathrm{veh} / \text { hour, } \\
3 \mathrm{x} \text { density for } \\
\text { junction }\end{array}$ & 2 days/site & Yes & $\begin{array}{l}\text { Vehicle } \\
\text { density }\end{array}$ \\
\hline $\begin{array}{l}\text { Ruellan et al } \\
2001\end{array}$ & Paris, France & & Yes & Yes & Highway & 8 lanes & 3 months & Yes & $\begin{array}{l}\text { Traffic } \\
\text { volumes, } \\
\text { speed, \% of } \\
\text { road } \\
\text { occupation }\end{array}$ \\
\hline $\begin{array}{l}\text { Wahiln et al } \\
2001\end{array}$ & $\begin{array}{l}\text { Copenhagen } \\
\text { \& Odense } \\
\text { Denmark }\end{array}$ & Yes & & Yes & $\begin{array}{l}\text { Urban street } \\
\text { canyon } \\
\text { Urban road }\end{array}$ & $\begin{array}{l}26,000 \mathrm{veh} / \text { day } \\
22,000 \mathrm{veh} / \text { day }\end{array}$ & $\begin{array}{l}47 \text { days } \\
17 \text { days }\end{array}$ & No & \\
\hline $\begin{array}{l}\text { Janssen et al } \\
1999\end{array}$ & $\begin{array}{l}\text { Wageningen } \\
\text { \& Arnhem, } \\
\text { Netherlands }\end{array}$ & & Yes & & $\begin{array}{l}2 \text { Urban } \\
\text { roads }\end{array}$ & $\begin{array}{l}8,900 \mathrm{veh} / \text { day } \\
15,000 \mathrm{veh} / \text { day }\end{array}$ & $\begin{array}{l}\text { 8hrs/weekd } \\
\text { ay for } \sim 3 \\
\text { months }\end{array}$ & Yes & $\begin{array}{l}\text { Manual } \\
\text { traffic } \\
\text { counts for } \\
\text { 10min of } \\
\text { each hour }\end{array}$ \\
\hline $\begin{array}{l}\text { Shi et al } \\
1999\end{array}$ & $\begin{array}{l}\text { Birmingham, } \\
\text { UK }\end{array}$ & & Yes & Yes & Busy road & $30,000 \mathrm{veh} /$ day & 4 days & No & \\
\hline $\begin{array}{l}\text { Harrison et } \\
\text { al } 1999\end{array}$ & $\begin{array}{l}\text { Birmingham, } \\
\text { UK }\end{array}$ & & Yes & Yes & Highway & $30,000 \mathrm{veh} /$ day & $\begin{array}{l}\text { Up to } 3 \\
\text { months }\end{array}$ & No & \\
\hline
\end{tabular}


Table 0-2 Near-road air quality monitoring studies with measurement locations at various distances from roadways. Colors indicate papers published with data collected from the same monitoring study.

\begin{tabular}{|c|c|c|c|c|c|c|c|c|c|}
\hline \multirow{2}{*}{$\begin{array}{c}\text { First } \\
\text { Author \& } \\
\text { Year }\end{array}$} & \multirow[t]{2}{*}{ Location } & \multirow[t]{2}{*}{$\begin{array}{l}\text { Study } \\
\text { Length }\end{array}$} & \multicolumn{2}{|c|}{$\begin{array}{c}\text { Closet Site to Road } \\
\text { Edge }\end{array}$} & \multicolumn{2}{|c|}{$\begin{array}{l}\text { Furthest Site from } \\
\text { Road Edge }\end{array}$} & \multirow[t]{2}{*}{$\begin{array}{l}\text { Roadway } \\
\text { Type }\end{array}$} & \multirow[t]{2}{*}{$\begin{array}{l}\text { Roadway } \\
\text { Descriptors }\end{array}$} & \multirow[t]{2}{*}{$\begin{array}{l}\text { Pollutants } \\
\text { Measured }\end{array}$} \\
\hline & & & $\begin{array}{l}\text { Down- } \\
\text { wind }\end{array}$ & Upwind & $\begin{array}{l}\text { Down- } \\
\text { wind }\end{array}$ & Upwind & & & \\
\hline $\begin{array}{l}\text { Kimbrough } \\
\text { et al } 2013 \\
\text { (a) }\end{array}$ & $\begin{array}{l}\text { Las Vegas, } \\
\text { Nevada }\end{array}$ & 1 year & $20 \mathrm{~m}$ & $100 \mathrm{~m}$ & $300 \mathrm{~m}$ & & $\begin{array}{l}\text { Interstate } \\
\text { highway }\end{array}$ & $\begin{array}{l}206,000 \\
\text { veh/day } 10 \% \\
\text { heavy-duty }\end{array}$ & $\begin{array}{l}\mathrm{CO}, \mathrm{NO} 2, \\
\mathrm{NOx}, \mathrm{BC}, \\
\text { traffic } \\
\text { volumes, } \\
\text { speed, vehicle } \\
\text { composition }\end{array}$ \\
\hline $\begin{array}{l}\text { Kimbrough } \\
\text { et al } 2013 \\
\text { (b) }\end{array}$ & $\begin{array}{l}\text { Las Vegas, } \\
\text { Nevada }\end{array}$ & 1 year & $20 \mathrm{~m}$ & $100 \mathrm{~m}$ & $300 \mathrm{~m}$ & & $\begin{array}{l}\text { Interstate } \\
\text { highway }\end{array}$ & $\begin{array}{l}200,000 \\
\text { veh/day } 10 \% \\
\text { heavy-duty }\end{array}$ & $\mathrm{NO} 2$ \\
\hline $\begin{array}{l}\text { Zhu et al } \\
2009\end{array}$ & $\begin{array}{l}\text { Austin, } \\
\text { Texas }\end{array}$ & 1 month & $\begin{array}{l}13 \mathrm{~m} \\
15 \mathrm{~m} \\
9 \mathrm{~m}\end{array}$ & $\begin{array}{l}5 \mathrm{~m} \\
30 \mathrm{~m} \\
52 \mathrm{~m}\end{array}$ & $\begin{array}{l}138 \mathrm{~m} \\
113 \mathrm{~m} \\
137 \mathrm{~m}\end{array}$ & $\begin{array}{l}\text { None } \\
\text { None } \\
91 \mathrm{~m}\end{array}$ & $\begin{array}{l}\text { State } \\
\text { highway } \\
\text { Interstate } \\
\text { Surface road }\end{array}$ & $\begin{array}{l}5 \% \text { heavy duty } \\
19 \% \text { heavy } \\
\text { duty } 34 \% \\
\text { heavy duty }\end{array}$ & $\begin{array}{l}\mathrm{CO}, \mathrm{NOx}, \\
\mathrm{UFP}, \mathrm{PM} 2.5\end{array}$ \\
\hline $\begin{array}{l}\text { Clements } \\
\text { et al } 2009\end{array}$ & $\begin{array}{l}\text { Austin, } \\
\text { Texas }\end{array}$ & 1 month & $\begin{array}{l}13 \mathrm{~m} \\
15 \mathrm{~m} \\
9 \mathrm{~m}\end{array}$ & $\begin{array}{l}5 \mathrm{~m} \\
30 \mathrm{~m} \\
52 \mathrm{~m}\end{array}$ & $\begin{array}{l}138 \mathrm{~m} \\
113 \mathrm{~m} \\
137 \mathrm{~m}\end{array}$ & $\begin{array}{l}\text { None } \\
\text { None } \\
91 \mathrm{~m}\end{array}$ & $\begin{array}{l}\text { State } \\
\text { highway } \\
\text { Interstate } \\
\text { Surface road }\end{array}$ & $\begin{array}{l}5 \% \text { heavy duty } \\
19 \% \text { heavy } \\
\text { duty } 34 \% \\
\text { heavy duty }\end{array}$ & $\begin{array}{l}\mathrm{CO}, \mathrm{NOx} \\
\mathrm{UFP}, \mathrm{PM} 2.5\end{array}$ \\
\hline
\end{tabular}




\begin{tabular}{|c|c|c|c|c|c|c|c|c|c|}
\hline $\begin{array}{l}\text { Birmili et } \\
\text { al } 2009\end{array}$ & $\begin{array}{l}\text { Berlin, } \\
\text { Germany }\end{array}$ & 10 weeks & $4 m$ & & $400 \mathrm{~m}$ & & Motorway & $\begin{array}{l}180,000 \\
\text { veh/day }\end{array}$ & $\begin{array}{l}\text { PNC, PSDs, } \\
\text { traffic counts } \\
\text { \& composition }\end{array}$ \\
\hline $\begin{array}{l}\text { Buonanno } \\
\text { et al } 2009\end{array}$ & $\begin{array}{l}\text { Cassino, } \\
\text { Italy }\end{array}$ & $\begin{array}{l}\text { 4hrs/day } \\
\text { for } 6 \text { days }\end{array}$ & 20 & $300 \mathrm{~m}$ & $400 \mathrm{~m}$ & & Highway & $\begin{array}{l}6 \text { lanes wide } \\
(53 \pm 15 \\
\text { veh/min } \\
\text { weekend }) \\
(95 \pm 12 \\
\text { veh/min } \\
\text { weekday) }\end{array}$ & $\begin{array}{l}\text { PNC, PSD, } \\
\text { particle } \\
\text { surface area, } \\
\text { traffic counts } \\
\& \text { composition }\end{array}$ \\
\hline $\begin{array}{l}\text { Hu et al } \\
2009\end{array}$ & $\begin{array}{l}\text { Los } \\
\text { Angeles, } \\
\text { California }\end{array}$ & $\begin{array}{l}3 \text { winter } \\
\text { days, } 2 \\
\text { summer } \\
\text { days }\end{array}$ & $100 \mathrm{~m}$ & $30 \mathrm{~m}$ & $2600 \mathrm{~m}$ & $1000 \mathrm{~m}$ & Freeway & & $\begin{array}{l}\text { PNC, PSD, } \\
\text { PM2.5, BC, } \\
\text { particle bound } \\
\text { PAH, CO, } \\
\text { CO2, NOx, } \\
\text { traffic flow }\end{array}$ \\
\hline $\begin{array}{l}\text { Baldauf et } \\
\text { al } 2008\end{array}$ & $\begin{array}{l}\text { Raleigh, } \\
\text { North } \\
\text { Carolina }\end{array}$ & $\sim 2$ months & $5 \mathrm{~m}$ & $50 \mathrm{~m}$ & $300 \mathrm{~m}$ & & $\begin{array}{l}\text { Interstate } \\
\text { highway }\end{array}$ & $\begin{array}{l}125,000 \\
\text { veh/day }\end{array}$ & $\begin{array}{l}\mathrm{CO}, \mathrm{CO} 2, \\
\text { NOx, THC, } \\
\text { PM10, PM2.5, } \\
\text { PNC, PSDs, } \\
\text { SF6, traffic } \\
\text { volumes, } \\
\text { speed \& } \\
\text { composition }\end{array}$ \\
\hline $\begin{array}{l}\text { Hagler et al } \\
2009\end{array}$ & $\begin{array}{l}\text { Raleigh, } \\
\text { North } \\
\text { Carolina }\end{array}$ & $\begin{array}{l}12 \mathrm{hrs} / \text { day } \\
\text { for } 8 \text { days }\end{array}$ & $20 \mathrm{~m}$ & $50 \mathrm{~m}$ & $300 \mathrm{~m}$ & & $\begin{array}{l}\text { Interstate } \\
\text { highway }\end{array}$ & $\begin{array}{l}125,000 \\
\text { veh/day }\end{array}$ & $\begin{array}{l}\text { PNC, THC, } \\
\text { CO, NO, BC, } \\
\text { PM2.5, PM10 }\end{array}$ \\
\hline
\end{tabular}




\begin{tabular}{|c|c|c|c|c|c|c|c|c|c|}
\hline $\begin{array}{l}\text { Thoma et } \\
\text { al } 2008\end{array}$ & $\begin{array}{l}\text { Raleigh, } \\
\text { North } \\
\text { Carolina }\end{array}$ & $\begin{array}{l}14 \text { hrs/day } \\
\text { for } 14 \\
\text { days }\end{array}$ & $7 \mathrm{~m}$ & & $17 \mathrm{~m}$ & & $\begin{array}{l}\text { Interstate } \\
\text { highway }\end{array}$ & $\begin{array}{l}125,000 \\
\text { veh/day }\end{array}$ & $\begin{array}{l}\text { NO (path- } \\
\text { integrated } \\
\text { optical remote } \\
\text { sensing), } \\
\text { traffic } \\
\text { volumes }\end{array}$ \\
\hline $\begin{array}{l}\text { Cho et al } \\
2009 \\
\text { (combined } \\
\text { with } \\
\text { toxicology) }\end{array}$ & $\begin{array}{l}\text { Raleigh, } \\
\text { North } \\
\text { Carolina }\end{array}$ & $\begin{array}{l}\text { Weekly } \\
\text { samples (2 } \\
\text { weeks) }\end{array}$ & $20 \mathrm{~m}$ & & $275 \mathrm{~m}$ & & $\begin{array}{l}\text { Interstate } \\
\text { highway }\end{array}$ & $\begin{array}{l}125,000 \\
\text { veh/day }\end{array}$ & $\begin{array}{l}\text { PM10. PM2.5, } \\
\text { UFP } \\
\text { (chemical } \\
\text { composition) }\end{array}$ \\
\hline $\begin{array}{l}\text { Venkatram } \\
\text { et al } 2009 \\
\text { (combined } \\
\text { with } \\
\text { modeling) }\end{array}$ & $\begin{array}{l}\text { Raleigh, } \\
\text { North } \\
\text { Carolina }\end{array}$ & & $\begin{array}{l}\text { NO: } 7 \mathrm{~m} \\
\text { VOC: } \\
10 \mathrm{~m}\end{array}$ & & $\begin{array}{l}\text { NO: } \\
17 \mathrm{~m} \\
\text { VOC: } \\
100 \mathrm{~m}\end{array}$ & & $\begin{array}{l}\text { Interstate } \\
\text { highway }\end{array}$ & $\begin{array}{l}125,000 \\
\text { veh/day }\end{array}$ & $\begin{array}{l}\text { NO, VOCs, } \\
\text { traffic data, }\end{array}$ \\
\hline $\begin{array}{l}\text { Baldauf et } \\
\text { al } 2008 \\
\text { (noise } \\
\text { barrier } \\
\text { effect) }\end{array}$ & $\begin{array}{l}\text { Raleigh, } \\
\text { North } \\
\text { Carolina }\end{array}$ & 2 months & $20 \mathrm{~m}$ & & $300 \mathrm{~m}$ & & $\begin{array}{l}\text { Interstate } \\
\text { highway }\end{array}$ & $\begin{array}{l}125,000 \\
\text { veh/day }\end{array}$ & $\begin{array}{l}\mathrm{CO}, \mathrm{PNC}, \\
\text { traffic data }\end{array}$ \\
\hline $\begin{array}{l}\text { Beckerman } \\
\text { et al } 2008\end{array}$ & $\begin{array}{l}\text { Toronto, } \\
\text { Canada }\end{array}$ & 1 week & $\begin{array}{l}4 \mathrm{~m} \\
57 \mathrm{~m}\end{array}$ & $\begin{array}{l}38 \mathrm{~m} \\
28 \mathrm{~m}\end{array}$ & $\begin{array}{l}875 \mathrm{~m} \\
986 \mathrm{~m}\end{array}$ & $\begin{array}{l}438 \mathrm{~m} \\
194 \mathrm{~m}\end{array}$ & 2 highways & $\begin{array}{l}395,400 \text { AADT } \\
349,100 \text { AADT }\end{array}$ & $\begin{array}{l}\text { NOx, O3, } \\
\text { VOCs, PM2.5, } \\
\text { PNC, SO2 }\end{array}$ \\
\hline
\end{tabular}




\begin{tabular}{|c|c|c|c|c|c|c|c|c|}
\hline $\begin{array}{l}\text { Richmond- } \\
\text { Bryant et al } \\
2009\end{array}$ & $\begin{array}{l}\text { Brooklyn, } \\
\text { New York }\end{array}$ & $\sim 3$ days & $\begin{array}{l}\text { Beneath } \\
\text { express } \\
\text { way w/ } \\
\text { inlet at } \\
8 \mathrm{~m} \text { road } \\
\text { height }\end{array}$ & & $400 \mathrm{~m}$ & $\begin{array}{l}\text { Expressway } \\
\text { to Street } \\
\text { canyon to } 3 \\
\text { stories } \\
\text { indoors }\end{array}$ & $\begin{array}{l}115,000 \\
\text { veh/day } \\
30,000 \mathrm{veh} / \text { day }\end{array}$ & $\begin{array}{l}\mathrm{PNC}, \mathrm{PM} 2.5, \\
\mathrm{NOX}, \mathrm{SOX}, \\
\mathrm{CO}, \mathrm{CO} 2\end{array}$ \\
\hline $\begin{array}{l}\text { Hahn et al } \\
2009 \text { (b) }\end{array}$ & $\begin{array}{l}\text { Brooklyn, } \\
\text { New York }\end{array}$ & $\begin{array}{l}4 \mathrm{hrs} / \text { day } \\
\text { for } 6 \text { days } \\
24 \mathrm{hrs} \text { for } \\
2 \text { days }\end{array}$ & $3 \mathrm{~m}$ & & $420 \mathrm{~m}$ & $\begin{array}{l}\text { Expressway } \\
\text { to Street } \\
\text { canyon }\end{array}$ & $\begin{array}{l}115,000 \\
\text { veh/day } \\
30,000 \mathrm{veh} / \text { day }\end{array}$ & PNC \\
\hline $\begin{array}{l}\text { Eisner et al } \\
2009\end{array}$ & $\begin{array}{l}\text { Brooklyn, } \\
\text { New York }\end{array}$ & $\begin{array}{l}4 \text { hours } 40 \\
\text { mins }\end{array}$ & $0 \mathrm{~m}$ & & $420 \mathrm{~m}$ & $\begin{array}{l}\text { Expressway } \\
\text { to Street } \\
\text { canyon }\end{array}$ & $\begin{array}{l}115,000 \\
\text { veh/day } \\
30,000 \mathrm{veh} / \text { day }\end{array}$ & PNC \\
\hline $\begin{array}{l}\text { Zhu et al } \\
2002(\mathrm{a}) \\
\text { summer } \\
\text { daytime }\end{array}$ & $\begin{array}{l}\text { Los } \\
\text { Angeles, } \\
\text { California }\end{array}$ & $\begin{array}{l}\text { 6hrs/day } \\
\text { for } 9 \text { days }\end{array}$ & $15 \mathrm{~m}$ & $285 \mathrm{~m}$ & $285 \mathrm{~m}$ & $\begin{array}{l}\mathrm{I}-405 \\
\text { freeway }\end{array}$ & $\begin{array}{l}9 \text { lanes } \\
13,900 \mathrm{veh} / \mathrm{hr} \\
>93 \% \text { gasoline }\end{array}$ & $\begin{array}{l}\mathrm{PNC}, \mathrm{PSD}, \\
\mathrm{CO}, \mathrm{BC}, \mathrm{PM} \\
\text { mass }\end{array}$ \\
\hline $\begin{array}{l}\text { Zhu et al } \\
2002(\mathrm{~b}) \\
\text { summer } \\
\text { daytime }\end{array}$ & $\begin{array}{l}\text { Los } \\
\text { Angeles, } \\
\text { California }\end{array}$ & $\begin{array}{l}5.5 \\
\text { hrs/day } \\
\text { for } 7 \text { days }\end{array}$ & $3 \mathrm{~m}$ & $187 \mathrm{~m}$ & $287 \mathrm{~m}$ & $\begin{array}{l}710 \\
\text { Freeway }\end{array}$ & $\begin{array}{l}8 \text { lanes } \\
180-230 \\
\text { veh } / \text { min }>25 \% \\
\text { heavy-duty }\end{array}$ & $\begin{array}{l}\mathrm{PNC}, \mathrm{PSD}, \\
\mathrm{CO}, \mathrm{BC}, \mathrm{PM} \\
\text { mass }\end{array}$ \\
\hline $\begin{array}{l}\text { Zhu et al } \\
2004\end{array}$ & $\begin{array}{l}\text { Los } \\
\text { Angeles, } \\
\text { California }\end{array}$ & $\begin{array}{l}\text { 4-6 } \\
\text { hrs/day } \\
\text { for } 7 \text { days }\end{array}$ & $\begin{array}{l}15 \mathrm{~m} \\
3 \mathrm{~m}\end{array}$ & $\begin{array}{l}285 \mathrm{~m} \\
187 \mathrm{~m}\end{array}$ & $\begin{array}{l}285 \mathrm{~m} \\
287 \mathrm{~m}\end{array}$ & $\begin{array}{l}\text { I-405 } \\
\text { freeway } \\
710 \text { freeway }\end{array}$ & $\begin{array}{l}\text { See details } \\
\text { above }\end{array}$ & $\begin{array}{l}\text { PNC, PSD, } \\
\mathrm{CO}, \mathrm{BC}\end{array}$ \\
\hline
\end{tabular}




\begin{tabular}{|c|c|c|c|c|c|c|c|c|c|}
\hline $\begin{array}{l}\text { winter } \\
\text { daytime }\end{array}$ & & & & & & & & & \\
\hline $\begin{array}{l}\text { Zhang et al } \\
2004\end{array}$ & $\begin{array}{l}\text { Los } \\
\text { Angeles, } \\
\text { California }\end{array}$ & $\begin{array}{l}\text { Data from } \\
\text { all } 3 \\
\text { above } \\
\text { combined }\end{array}$ & $\begin{array}{l}\text { Data } \\
\text { from all } \\
3 \text { above } \\
\text { combine } \\
\text { d }\end{array}$ & $\begin{array}{l}\text { Data } \\
\text { from all } \\
3 \text { above } \\
\text { combine } \\
\text { d }\end{array}$ & $\begin{array}{l}\text { Data } \\
\text { from } \\
\text { all } 3 \\
\text { above } \\
\text { combin } \\
\text { ed }\end{array}$ & $\begin{array}{l}\text { Data } \\
\text { from all } \\
3 \text { above } \\
\text { combine } \\
\text { d }\end{array}$ & $\begin{array}{l}\text { Data from } \\
\text { all } 3 \text { above } \\
\text { combined }\end{array}$ & $\begin{array}{l}\text { Data from all } 3 \\
\text { above } \\
\text { combined }\end{array}$ & $\begin{array}{l}\text { Data from all } \\
3 \text { above } \\
\text { combined }\end{array}$ \\
\hline $\begin{array}{l}\text { Zhu et al } \\
2006 \\
\text { winter } \\
\text { nighttime }\end{array}$ & $\begin{array}{l}\text { Los } \\
\text { Angeles, } \\
\text { California }\end{array}$ & $\begin{array}{l}\text { 5hrs/night } \\
\text { for } 7 \\
\text { nights }\end{array}$ & $15 \mathrm{~m}$ & $285 \mathrm{~m}$ & $285 \mathrm{~m}$ & & $\begin{array}{l}\text { I-405 } \\
\text { freeway }\end{array}$ & $\begin{array}{l}\text { See details } \\
\text { above }\end{array}$ & $\begin{array}{l}\text { PNC, PSD, } \\
\text { PM2.5, PM10 }\end{array}$ \\
\hline $\begin{array}{l}\text { Kuhn et al } \\
2005 \\
\text { summer }\end{array}$ & $\begin{array}{l}\text { Los } \\
\text { Angeles, } \\
\text { California }\end{array}$ & $\begin{array}{l}\text { 7hrs/day } \\
\text { for } 6 \\
\text { weeks }\end{array}$ & $2.5 \mathrm{~m}$ & & $50 \mathrm{~m}$ & & Freeway & $\begin{array}{l}\text { Only light duty } \\
\text { vehicles } \\
\text { allowed. } \\
5700 \text { veh/hour }\end{array}$ & $\begin{array}{l}\text { Particle } \\
\text { volatility \& } \\
\text { composition, } \\
\text { PM2.5, PM10, } \\
\text { PNC, PSD, } \\
\text { traffic } \\
\text { volumes }\end{array}$ \\
\hline $\begin{array}{l}\text { Kuhn et al } \\
2005 \mathrm{~b} \\
\text { winter }\end{array}$ & $\begin{array}{l}\text { Los } \\
\text { Angeles, } \\
\text { California }\end{array}$ & $\begin{array}{l}\text { 7hrs/day } \\
\text { for } 2 \\
\text { weeks }\end{array}$ & $2.5 \mathrm{~m}$ & & $50 \mathrm{~m}$ & & Freeway & $\begin{array}{l}\text { Only light duty } \\
\text { vehicles } \\
\text { allowed. } \\
5100 \text { veh/hour }\end{array}$ & $\begin{array}{l}\text { Particle } \\
\text { volatility \& } \\
\text { composition, } \\
\text { PM2.5, PM10, } \\
\text { PNC, PSD, } \\
\text { traffic } \\
\text { volumes }\end{array}$ \\
\hline
\end{tabular}




\begin{tabular}{|c|c|c|c|c|c|c|c|c|c|}
\hline $\begin{array}{l}\text { Nanzetta } \\
\text { and } \\
\text { Holmen } \\
2004\end{array}$ & $\begin{array}{l}\text { Sacramento } \\
\text {, California }\end{array}$ & 3 days & $3 \mathrm{~m}$ & $6 \mathrm{~m}$ & & $9 \mathrm{~m}$ & Freeway & $\begin{array}{l}\text { Free flow } \\
\text { speeds } 65- \\
85 \mathrm{mph}\end{array}$ & $\begin{array}{l}\text { PNC, PSDs, } \\
\text { traffic counts, } \\
\text { composition(v } \\
\text { ideo) }\end{array}$ \\
\hline $\begin{array}{l}\text { Gidhagen } \\
\text { et al } 2004\end{array}$ & $\begin{array}{l}\text { Stockholm, } \\
\text { Sweden }\end{array}$ & 6 weeks & $38 \mathrm{~m}$ & $\begin{array}{l}\text { (Backgr } \\
\text { ound } \\
\text { site } \\
45 \mathrm{~km} \\
\text { away) }\end{array}$ & $91 \mathrm{~m}$ & & Highway & $\begin{array}{l}52,300 \mathrm{veh} / \text { day } \\
\text { (rush hour } \\
5000 \mathrm{veh} / \text { hour) }\end{array}$ & $\begin{array}{l}\text { PNC, NOx, } \\
\text { PSD traffic } \\
\text { volume, } \\
\text { speed, } \\
\text { composition }\end{array}$ \\
\hline $\begin{array}{l}\text { Tiita et al } \\
2002\end{array}$ & $\begin{array}{l}\text { Kuopio, } \\
\text { Finland }\end{array}$ & $\begin{array}{l}16 \mathrm{hr} / \text { day } \\
\text { for } 27 \\
\text { days }\end{array}$ & $12 \mathrm{~m}$ & & $87 \mathrm{~m}$ & & Motorway & $19,000 \mathrm{veh} /$ day & PM2.5 \\
\hline $\begin{array}{l}\text { Hitchins et } \\
\text { al } 2000\end{array}$ & $\begin{array}{l}\text { Brisbane, } \\
\text { Australia }\end{array}$ & $\begin{array}{l}32 \text { hours } \\
\text { total for } \\
\text { both sites }\end{array}$ & $\begin{array}{l}15 \mathrm{~m} \\
15 \mathrm{~m}\end{array}$ & & $\begin{array}{l}375 \mathrm{~m} \\
280 \mathrm{~m}\end{array}$ & & $\begin{array}{l}2 \text { major } \\
\text { roads }\end{array}$ & $\begin{array}{l}3400 \mathrm{veh} / \text { hour } \\
2130 \mathrm{veh} / \text { hour }\end{array}$ & $\begin{array}{l}\text { PNC, PM2.5, } \\
\text { traffic counts } \\
\text { \& composition }\end{array}$ \\
\hline
\end{tabular}


B. Appendix B: Supplemental Plots and Tables for Chapter 3's Matching Analysis
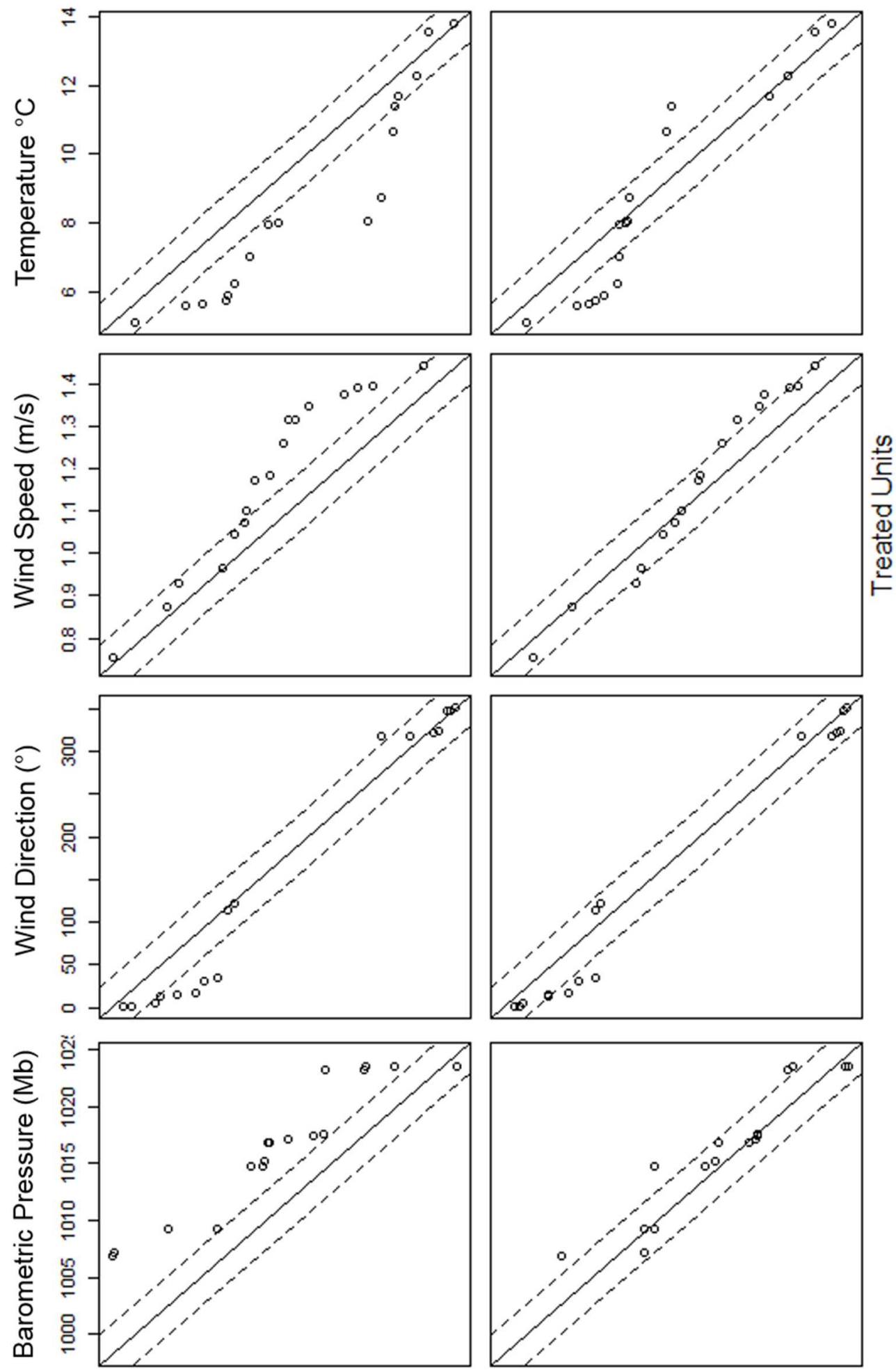

Figure B-1 QQ plots for unmatched and matched 5 min subset, Case Study 1 Morning. 

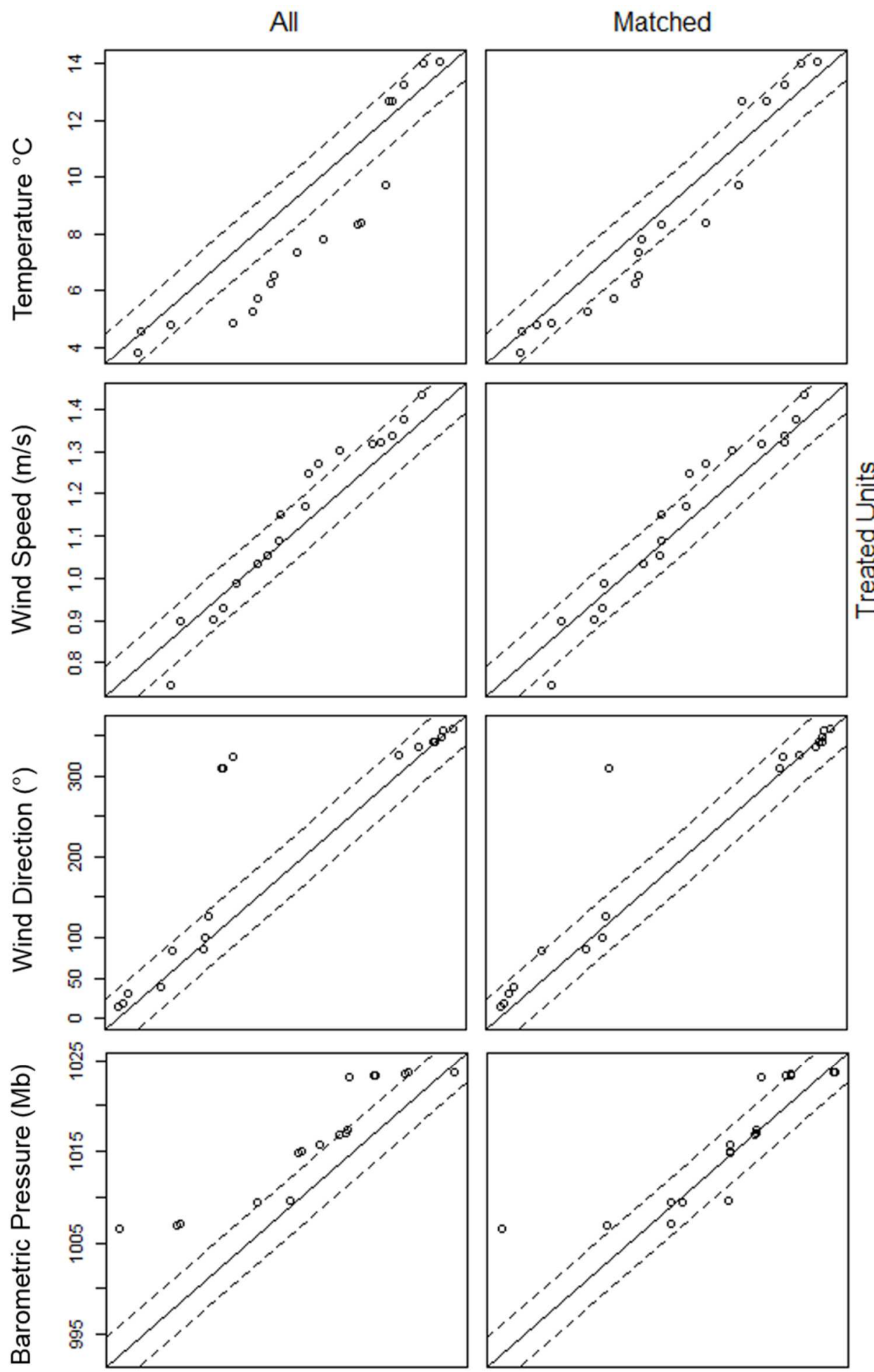

Control Units

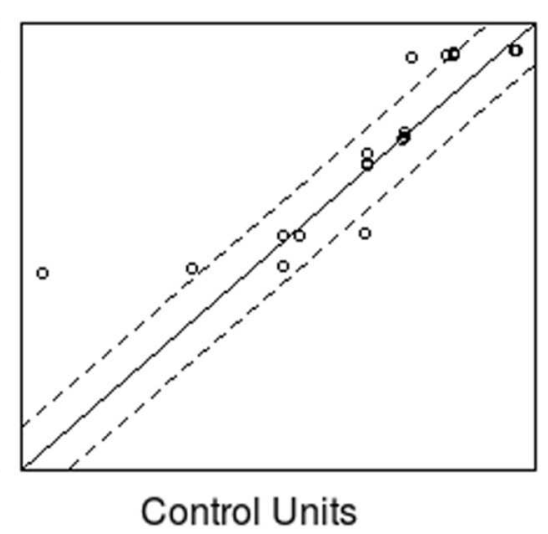

Figure B-2 QQ plots for unmatched (All) and matched 15 min subset, Case Study 1 Morning. 


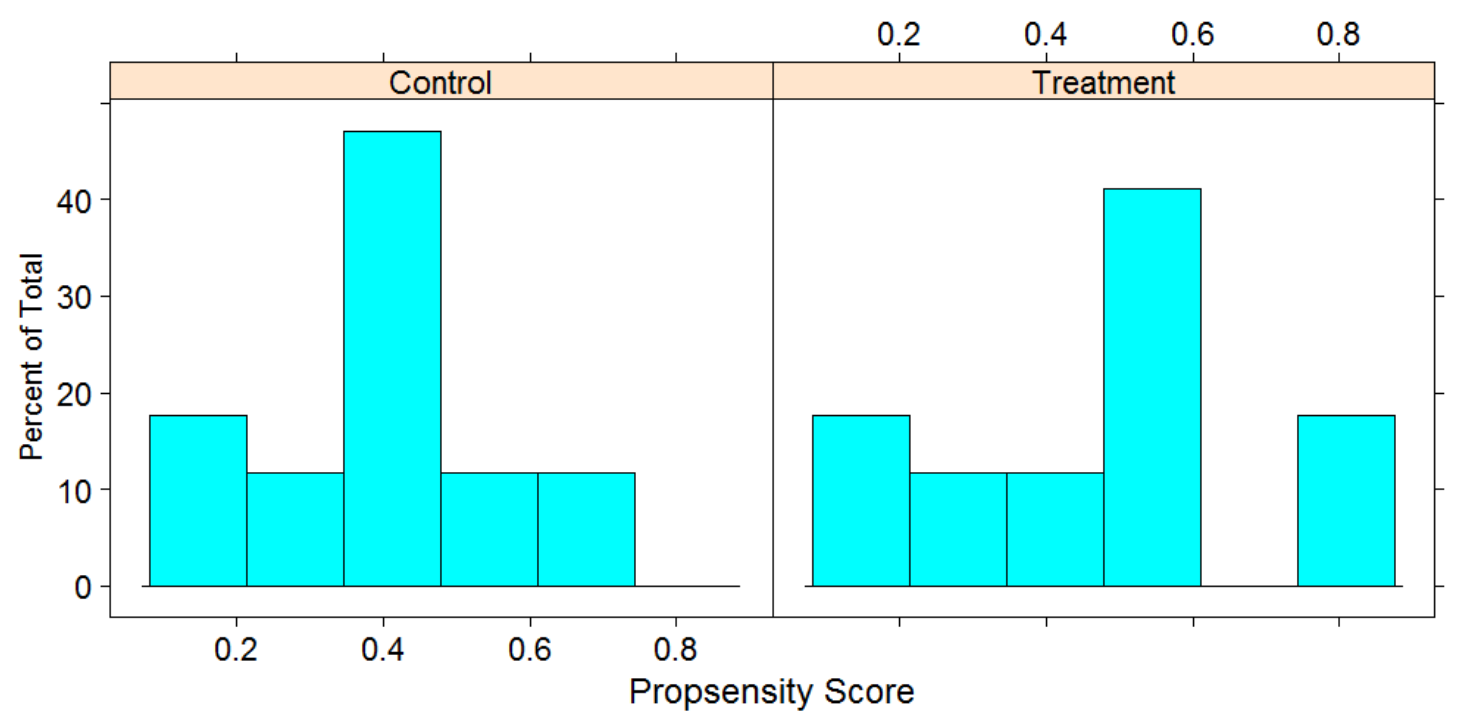

Figure B-3 Propensity score histograms for matched 5 min subset, Case Study 1 Morning.

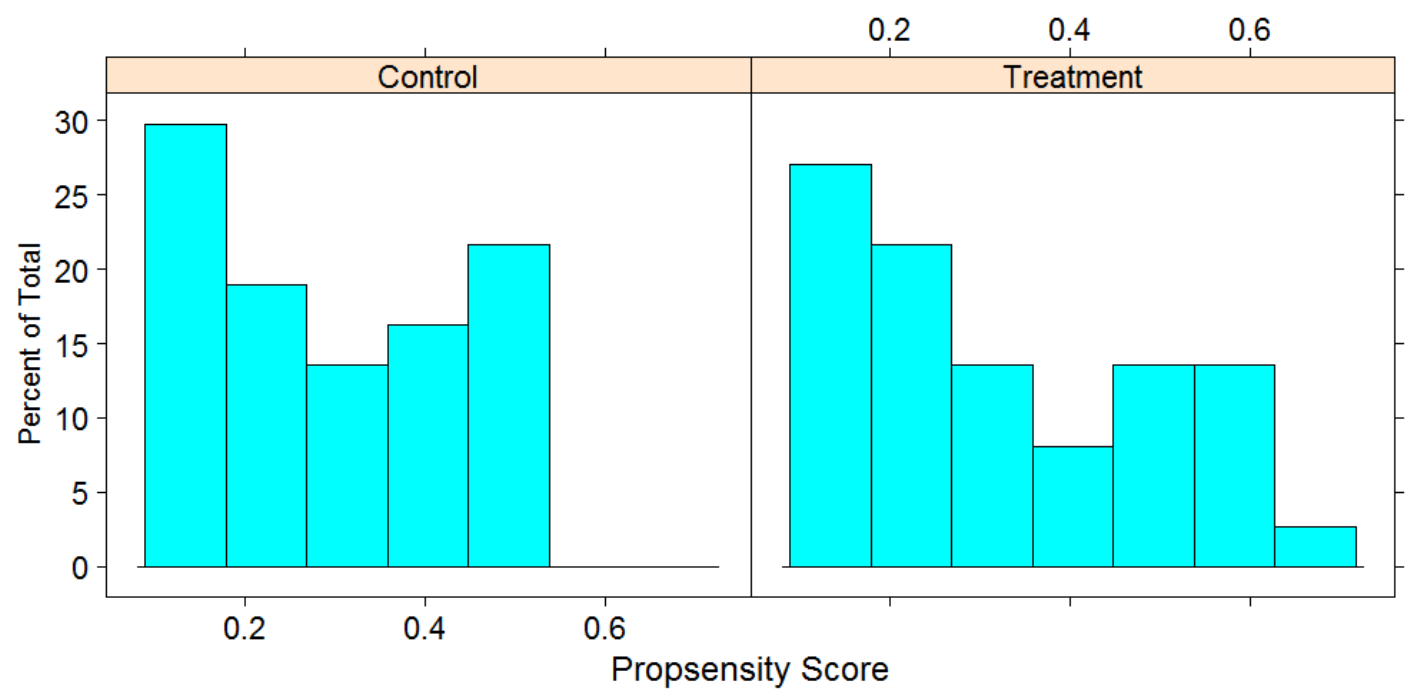

Figure B-4 Propensity score histograms for matched 15 min subset, Case Study 1 Morning 
Table B-1 Case study 1 Morning: CL and DS t-test results for unmatched and matched samples. Full datasets are in parentheses.

\begin{tabular}{|c|c|c|c|c|c|c|c|c|}
\hline Data Subset & $\begin{array}{l}\text { CL } \\
\text { Control }\end{array}$ & $\begin{array}{l}\text { CL } \\
\text { Trmt }\end{array}$ & $\begin{array}{l}\text { CL } \\
\text { t-value }\end{array}$ & $\begin{array}{l}\text { CL } \\
p \text {-value }\end{array}$ & $\begin{array}{l}\text { DS } \\
\text { Control }\end{array}$ & $\begin{array}{l}\text { DS } \\
\text { Trmt }\end{array}$ & $\begin{array}{l}\text { DS } \\
\text { t-value }\end{array}$ & $\begin{array}{l}\text { DS } \\
\text { p-value }\end{array}$ \\
\hline $\begin{array}{l}\text { Unmatched } \\
5 \mathrm{~min}\end{array}$ & $\begin{array}{l}130 \\
(130)\end{array}$ & $\begin{array}{l}117 \\
(118)\end{array}$ & $\begin{array}{l}8.5 \\
(24)\end{array}$ & $\begin{array}{l}<0.01 \\
(<0.01)\end{array}$ & $\begin{array}{l}123 \\
(124)\end{array}$ & $\begin{array}{l}118 \\
(121)\end{array}$ & $\begin{array}{l}1 \\
(1.4)\end{array}$ & $\begin{array}{l}0.33 \\
(0.18)\end{array}$ \\
\hline $\begin{array}{l}\text { Matched } \\
5 \mathrm{~min}\end{array}$ & $\begin{array}{l}130 \\
(130)\end{array}$ & $\begin{array}{l}117 \\
(118)\end{array}$ & $\begin{array}{l}5.7 \\
(18)\end{array}$ & $\begin{array}{l}<0.01 \\
(<0.01)\end{array}$ & $\begin{array}{l}121 \\
(123)\end{array}$ & $\begin{array}{l}118 \\
(121)\end{array}$ & $\begin{array}{l}0.5 \\
(0.9)\end{array}$ & $\begin{array}{l}0.6 \\
(0.35)\end{array}$ \\
\hline $\begin{array}{l}\text { Unmatched } \\
15 \mathrm{~min}\end{array}$ & $\begin{array}{l}129 \\
(129)\end{array}$ & $\begin{array}{l}118 \\
(118)\end{array}$ & $\begin{array}{l}12 \\
(19)\end{array}$ & $\begin{array}{l}<0.01 \\
(<0.01)\end{array}$ & $\begin{array}{l}127 \\
(125)\end{array}$ & $\begin{array}{l}122 \\
(125)\end{array}$ & $\begin{array}{l}1.3 \\
(0.3)\end{array}$ & $\begin{array}{l}0.22 \\
(0.8)\end{array}$ \\
\hline $\begin{array}{l}\text { Matched } \\
15 \mathrm{~min}\end{array}$ & $\begin{array}{l}129 \\
(129)\end{array}$ & $\begin{array}{l}118 \\
(118)\end{array}$ & $\begin{array}{l}9 \\
(17)\end{array}$ & $\begin{array}{l}<0.01 \\
(<0.01)\end{array}$ & $\begin{array}{l}126 \\
(127)\end{array}$ & $\begin{array}{l}122 \\
(125)\end{array}$ & $\begin{array}{l}0.8 \\
(0.7)\end{array}$ & $\begin{array}{l}0.4 \\
(0.5)\end{array}$ \\
\hline
\end{tabular}


Table B-2 Case Study 1 Morning: Approach DS t-test results for unmatched and matched samples. Full datasets are in parentheses

\begin{tabular}{|c|c|c|c|c|c|c|c|c|c|c|c|c|}
\hline $\begin{array}{l}\text { Un- } \\
\text { matched } \\
5 \text { min }\end{array}$ & $\begin{array}{l}\text { EB } \\
\text { Through } \\
\text { DS } \\
\text { Control } \\
43 \\
(43)\end{array}$ & $\begin{array}{l}\text { EB } \\
\text { Through } \\
\text { DS } \\
\text { Trmt } \\
44 \\
(44)\end{array}$ & $\begin{array}{l}\text { EB } \\
\text { Through } \\
\text { DS } \\
\text { t-value } \\
-0.2 \\
(-1.7)\end{array}$ & $\begin{array}{l}\text { EB } \\
\text { Through } \\
\text { DS } \\
\text { p-value } \\
0.82 \\
(0.1)\end{array}$ & $\begin{array}{l}\text { WB } \\
\text { Through } \\
\text { DS } \\
\text { Control } \\
86 \\
(89)\end{array}$ & $\begin{array}{l}\text { WB } \\
\text { Through } \\
\text { DS } \\
\text { Trmt } \\
84 \\
(84)\end{array}$ & $\begin{array}{l}\text { WB } \\
\text { Through } \\
\text { DS } \\
\text { t-value } \\
0.6 \\
(2.5)\end{array}$ & $\begin{array}{l}\text { WB } \\
\text { Through } \\
\text { DS } \\
\text { p-value } \\
0.55 \\
(0.01)\end{array}$ & $\begin{array}{l}\text { NB/SB } \\
\text { Through } \\
\text { Control } \\
82 \\
(83)\end{array}$ & $\begin{array}{l}\text { NB/SB } \\
\text { Through } \\
\text { Trmt } \\
84 \\
(79)\end{array}$ & $\begin{array}{l}\text { NB/SB } \\
\text { Through } \\
\text { t-value } \\
-0.4 \\
(1.9)\end{array}$ & $\begin{array}{l}\text { NB/SB } \\
\text { Through } \\
\text { p-value }\end{array}$ \\
\hline $\begin{array}{l}\text { Matched } \\
5 \mathrm{~min}\end{array}$ & $\begin{array}{l}43 \\
(43)\end{array}$ & $\begin{array}{l}44 \\
(44)\end{array}$ & $\begin{array}{l}-0.3 \\
(-1.7)\end{array}$ & $\begin{array}{l}0.81 \\
(0.1)\end{array}$ & $\begin{array}{l}90 \\
(90)\end{array}$ & $\begin{array}{l}84 \\
(84)\end{array}$ & $\begin{array}{l}0.9 \\
(2.2)\end{array}$ & $\begin{array}{l}0.36 \\
(0.03)\end{array}$ & $\begin{array}{l}88 \\
(82)\end{array}$ & $\begin{array}{l}84 \\
(80)\end{array}$ & $\begin{array}{l}0.8 \\
(1.5)\end{array}$ & $\begin{array}{l}0.43 \\
(0.14)\end{array}$ \\
\hline $\begin{array}{l}\text { Un- } \\
\text { matched } \\
15 \mathrm{~min}\end{array}$ & $\begin{array}{l}44 \\
(44)\end{array}$ & $\begin{array}{l}45 \\
(45)\end{array}$ & $\begin{array}{l}-0.6 \\
(-1.6)\end{array}$ & $\begin{array}{l}0.6 \\
(0.12)\end{array}$ & $\begin{array}{l}96 \\
(90)\end{array}$ & $\begin{array}{l}89 \\
(87)\end{array}$ & $\begin{array}{l}1.1 \\
(0.7)\end{array}$ & $\begin{array}{l}0.26 \\
(0.51)\end{array}$ & $\begin{array}{l}85 \\
(82)\end{array}$ & $\begin{array}{l}78 \\
(80)\end{array}$ & $\begin{array}{l}2.1 \\
(0.9)\end{array}$ & $\begin{array}{l}0.05 \\
(0.35)\end{array}$ \\
\hline $\begin{array}{l}\text { Matched } \\
15 \mathrm{~min}\end{array}$ & $\begin{array}{l}44 \\
(44)\end{array}$ & $\begin{array}{l}45 \\
(45)\end{array}$ & $\begin{array}{l}-0.6 \\
(-0.6)\end{array}$ & $\begin{array}{l}0.53 \\
(0.57)\end{array}$ & $\begin{array}{l}92 \\
(90)\end{array}$ & $\begin{array}{l}89 \\
(87)\end{array}$ & $\begin{array}{l}0.4 \\
(0.7)\end{array}$ & $\begin{array}{l}0.69 \\
(0.5)\end{array}$ & $\begin{array}{l}84 \\
(82)\end{array}$ & $\begin{array}{l}78 \\
(80)\end{array}$ & $\begin{array}{l}1.5 \\
(0.9)\end{array}$ & $\begin{array}{l}0.15 \\
(0.4)\end{array}$ \\
\hline
\end{tabular}

$\bar{\omega}$ 
Table B-3 Case Study 1 Morning: Normalized NO and NO2 t-test results for unmatched and matched samples. Full datasets are in parentheses.

\begin{tabular}{|c|c|c|c|c|c|c|c|c|}
\hline Data Subset & $\begin{array}{l}\text { N- NO } \\
\text { Control }\end{array}$ & $\begin{array}{l}\text { N- NO } \\
\text { Trmt }\end{array}$ & $\begin{array}{l}\mathrm{N}-\mathrm{NO} \\
\mathrm{t} \text {-value }\end{array}$ & $\begin{array}{l}\mathrm{N} \text { - NO } \\
\text { p-value }\end{array}$ & $\begin{array}{l}\mathrm{N}-\mathrm{NO} 2 \\
\text { Control }\end{array}$ & $\begin{array}{l}\text { N- NO2 } \\
\text { Trmt }\end{array}$ & $\begin{array}{l}\mathrm{N}-\mathrm{NO} 2 \\
\text { t-value }\end{array}$ & $\begin{array}{l}\mathrm{N} \text { - NO2 } \\
\text { p-value }\end{array}$ \\
\hline $\begin{array}{l}\text { Unmatched } \\
5 \mathrm{~min}\end{array}$ & $\begin{array}{l}1.7 \\
(1.6)\end{array}$ & $\begin{array}{l}1.8 \\
(1.6)\end{array}$ & $\begin{array}{l}-0.91 \\
(-0.2)\end{array}$ & $\begin{array}{l}0.37 \\
(0.88)\end{array}$ & $\begin{array}{l}1.2 \\
(1.2)\end{array}$ & $\begin{array}{l}1.2 \\
(1.1)\end{array}$ & $\begin{array}{l}0.8 \\
(3.8)\end{array}$ & $\begin{array}{l}0.43 \\
(<0.01)\end{array}$ \\
\hline $\begin{array}{l}\text { Matched } \\
5 \mathrm{~min}\end{array}$ & $\begin{array}{l}1.6 \\
(1.6)\end{array}$ & $\begin{array}{l}1.8 \\
(1.6)\end{array}$ & $\begin{array}{l}-1.3 \\
(-0.8)\end{array}$ & $\begin{array}{l}0.21 \\
(0.4)\end{array}$ & $\begin{array}{l}1.2 \\
(1.2)\end{array}$ & $\begin{array}{l}1.2 \\
(1.1)\end{array}$ & $\begin{array}{l}-0.3 \\
(3)\end{array}$ & $\begin{array}{l}0.76 \\
(<0.01)\end{array}$ \\
\hline $\begin{array}{l}\text { Unmatched } \\
15 \mathrm{~min}\end{array}$ & $\begin{array}{l}1.6 \\
(1.6)\end{array}$ & $\begin{array}{l}1.6 \\
(1.6)\end{array}$ & $\begin{array}{l}-0.3 \\
(-0.4)\end{array}$ & $\begin{array}{l}0.8 \\
(0.68)\end{array}$ & $\begin{array}{l}1.2 \\
(1.2)\end{array}$ & $\begin{array}{l}1.1 \\
(1.1)\end{array}$ & $\begin{array}{l}1.2 \\
(2.2)\end{array}$ & $\begin{array}{l}0.24 \\
(0.03)\end{array}$ \\
\hline $\begin{array}{l}\text { Matched } \\
15 \mathrm{~min}\end{array}$ & $\begin{array}{l}1.6 \\
(1.5)\end{array}$ & $\begin{array}{l}1.6 \\
(1.6)\end{array}$ & $\begin{array}{l}0.06 \\
(-2.1)\end{array}$ & $\begin{array}{l}0.95 \\
(0.04)\end{array}$ & $\begin{array}{l}1.2 \\
(1.2)\end{array}$ & $\begin{array}{l}1.1 \\
(1.1)\end{array}$ & $\begin{array}{l}0.8 \\
(0.7)\end{array}$ & $\begin{array}{l}0.42 \\
(0.51)\end{array}$ \\
\hline
\end{tabular}


Table B-4 Case Study 1 Morning: Roadside NO and $\mathrm{NO}_{2}$ (cuberoot transformed) t-test results for unmatched and matched samples. Full datasets are in parentheses.

\begin{tabular}{|c|c|c|c|c|c|c|c|c|}
\hline Data Subset & $\begin{array}{l}\text { CR- NO } \\
\text { Control }\end{array}$ & $\begin{array}{l}\text { CR- NO } \\
\text { Trmt }\end{array}$ & $\begin{array}{l}\text { CR-NO } \\
\text { t-value }\end{array}$ & $\begin{array}{l}\text { CR-NO } \\
\text { p-value }\end{array}$ & $\begin{array}{l}\mathrm{CR}-\mathrm{NO}_{2} \\
\text { Control }\end{array}$ & $\begin{array}{l}\mathrm{CR}-\mathrm{NO}_{2} \\
\text { Trmt }\end{array}$ & $\begin{array}{l}\mathrm{CR}-\mathrm{NO}_{2} \\
\text { t-value }\end{array}$ & $\begin{array}{l}\mathrm{CR}-\mathrm{NO}_{2} \\
\text { p-value }\end{array}$ \\
\hline $\begin{array}{l}\text { Unmatched } \\
5 \mathrm{~min}\end{array}$ & $\begin{array}{l}3.5 \\
(3.5)\end{array}$ & $\begin{array}{l}3.7 \\
(3.4)\end{array}$ & $\begin{array}{l}-0.8 \\
(1.4)\end{array}$ & $\begin{array}{l}0.44 \\
(0.16)\end{array}$ & $\begin{array}{l}2.8 \\
(2.8)\end{array}$ & $\begin{array}{l}2.9 \\
(2.8)\end{array}$ & $\begin{array}{l}-0.6 \\
(-1)\end{array}$ & $\begin{array}{l}0.55 \\
(0.29)\end{array}$ \\
\hline $\begin{array}{l}\text { Matched } \\
5 \mathrm{~min}\end{array}$ & $\begin{array}{l}3.5 \\
(3.5)\end{array}$ & $\begin{array}{l}3.6 \\
(3.4)\end{array}$ & $\begin{array}{l}-0.9 \\
(1.3)\end{array}$ & $\begin{array}{l}0.39 \\
(0.18)\end{array}$ & $\begin{array}{l}2.8 \\
(2.8)\end{array}$ & $\begin{array}{l}2.9 \\
(2.8)\end{array}$ & $\begin{array}{l}-0.9 \\
(-0.1)\end{array}$ & $\begin{array}{l}0.36 \\
(0.94)\end{array}$ \\
\hline $\begin{array}{l}\text { Unmatched } \\
15 \mathrm{~min}\end{array}$ & $\begin{array}{l}3.6 \\
(3.5)\end{array}$ & $\begin{array}{l}3.5 \\
(3.5)\end{array}$ & $\begin{array}{l}1 \\
(0.4)\end{array}$ & $\begin{array}{l}0.32 \\
(0.7)\end{array}$ & $\begin{array}{l}2.8 \\
(2.8)\end{array}$ & $\begin{array}{l}2.8 \\
(2.9)\end{array}$ & $\begin{array}{l}-0.6 \\
(-2)\end{array}$ & $\begin{array}{l}0.55 \\
(0.05)\end{array}$ \\
\hline $\begin{array}{l}\text { Matched } \\
15 \mathrm{~min}\end{array}$ & $\begin{array}{l}3.5 \\
(3.7)\end{array}$ & $\begin{array}{l}3.5 \\
(3.5)\end{array}$ & $\begin{array}{l}0.1 \\
(1.3)\end{array}$ & $\begin{array}{l}0.9 \\
(0.2)\end{array}$ & $\begin{array}{l}2.7 \\
(2.8)\end{array}$ & $\begin{array}{l}2.8 \\
(2.9)\end{array}$ & $\begin{array}{l}-1.1 \\
(-1)\end{array}$ & $\begin{array}{l}0.28 \\
(0.31)\end{array}$ \\
\hline
\end{tabular}


Table B-1 Case Study 1 Morning: Background $\mathrm{NO}$ and $\mathrm{NO}_{2}$ (cuberoot transformed) t-test results for unmatched and matched samples. Full datasets are in parentheses.

\begin{tabular}{|c|c|c|c|c|c|c|c|c|}
\hline Data Subset & $\begin{array}{l}\text { DEQ NO } \\
\text { Control }\end{array}$ & $\begin{array}{l}\text { DEQ NO } \\
\text { Trmt }\end{array}$ & $\begin{array}{l}\text { DEQ NO } \\
\text { t-value }\end{array}$ & $\begin{array}{l}\text { DEQ NO } \\
\text { p-value }\end{array}$ & $\begin{array}{l}\mathrm{DEQ} \mathrm{NO}_{2} \\
\text { Control }\end{array}$ & $\begin{array}{l}\text { DEQ } \mathrm{NO}_{2} \\
\text { Trmt }\end{array}$ & $\begin{array}{l}\mathrm{DEQ} \mathrm{NO}_{2} \\
\text { t-value }\end{array}$ & $\begin{array}{l}\mathrm{DEQ} \mathrm{NO}_{2} \\
\text { p-value }\end{array}$ \\
\hline $\begin{array}{l}\text { Unmatched } \\
5 \mathrm{~min}\end{array}$ & $\begin{array}{l}2.3 \\
(2.3)\end{array}$ & $\begin{array}{l}2.2 \\
(2.2)\end{array}$ & $\begin{array}{l}0.7 \\
(-6.4)\end{array}$ & $\begin{array}{l}0.47 \\
(0.04)\end{array}$ & $\begin{array}{l}2.3 \\
(2.3)\end{array}$ & $\begin{array}{l}2.5 \\
(2.5)\end{array}$ & $\begin{array}{l}-1.6 \\
(-6.4)\end{array}$ & $\begin{array}{l}0.12 \\
(<0.01)\end{array}$ \\
\hline $\begin{array}{l}\text { Matched } \\
5 \mathrm{~min}\end{array}$ & $\begin{array}{l}2.2 \\
(2.4)\end{array}$ & $\begin{array}{l}2.2 \\
(2.2)\end{array}$ & $\begin{array}{l}0.3 \\
(2.3)\end{array}$ & $\begin{array}{l}0.76 \\
(0.02)\end{array}$ & $\begin{array}{l}2.4 \\
(2.3)\end{array}$ & $\begin{array}{l}2.5 \\
(2.5)\end{array}$ & $\begin{array}{l}-0.2 \\
(-3.6)\end{array}$ & $\begin{array}{l}0.85 \\
(<0.01)\end{array}$ \\
\hline $\begin{array}{l}\text { Unmatched } \\
15 \mathrm{~min}\end{array}$ & $\begin{array}{l}2.5 \\
(2.4)\end{array}$ & $\begin{array}{l}2.3 \\
(2.3)\end{array}$ & $\begin{array}{l}0.8 \\
(0.7)\end{array}$ & $\begin{array}{l}0.43 \\
(0.46)\end{array}$ & $\begin{array}{l}2.4 \\
(2.3)\end{array}$ & $\begin{array}{l}2.5 \\
(2.5)\end{array}$ & $\begin{array}{l}-1.8 \\
(-4.2)\end{array}$ & $\begin{array}{l}0.08 \\
(<0.01)\end{array}$ \\
\hline $\begin{array}{l}\text { Matched } \\
15 \mathrm{~min}\end{array}$ & $\begin{array}{l}2.3 \\
(2.6)\end{array}$ & $\begin{array}{l}2.3 \\
(2.3)\end{array}$ & $\begin{array}{l}0.1 \\
(.23)\end{array}$ & $\begin{array}{l}0.93 \\
(0.03)\end{array}$ & $\begin{array}{l}2.4 \\
(2.5)\end{array}$ & $\begin{array}{l}2.5 \\
(2.5)\end{array}$ & $\begin{array}{l}-1.4 \\
(-1.4)\end{array}$ & $\begin{array}{l}0.19 \\
(0.17)\end{array}$ \\
\hline
\end{tabular}



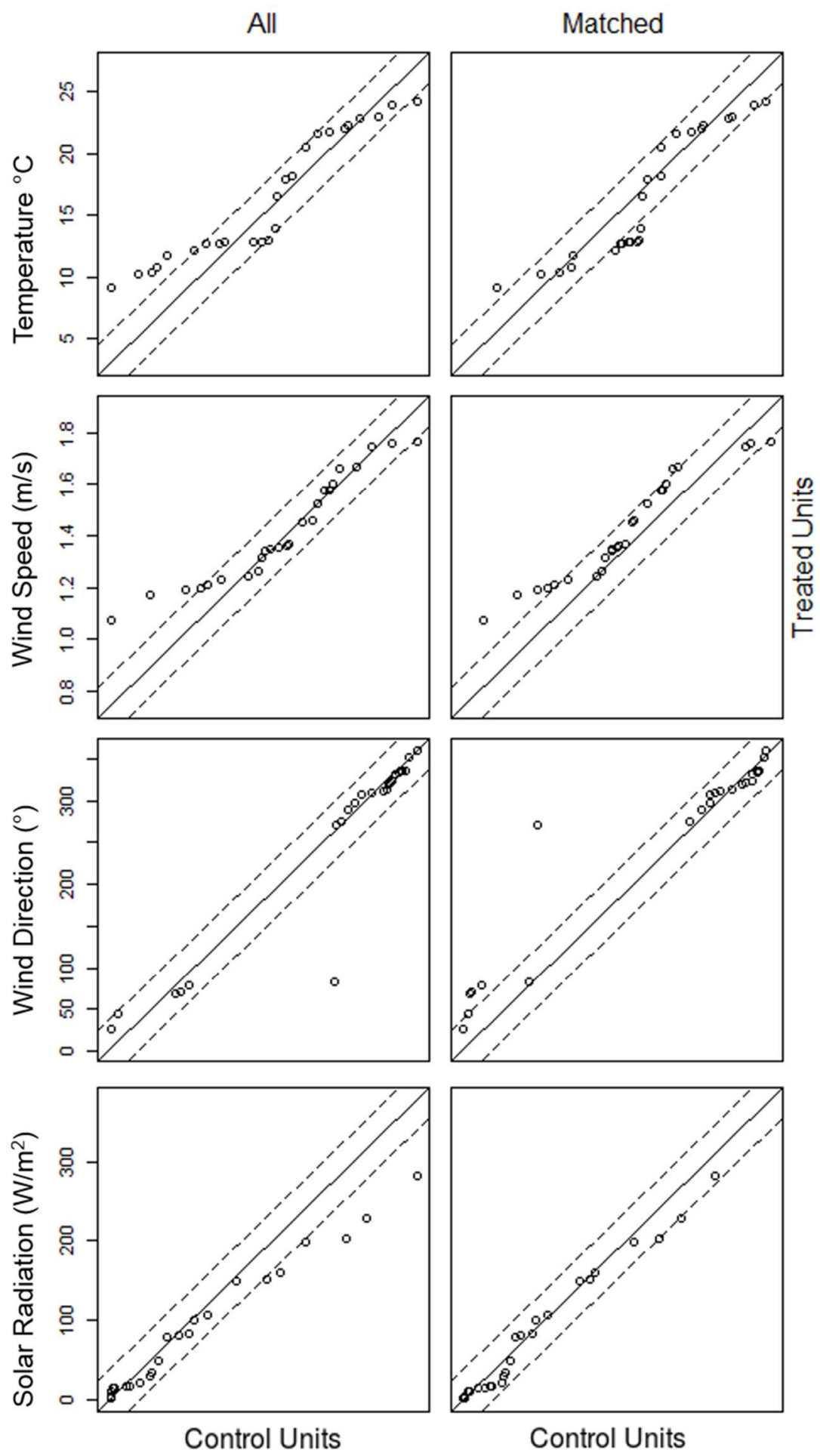

Figure B-5 QQ plots for unmatched and matched 5 min subset, Case Study 1 Evening. 

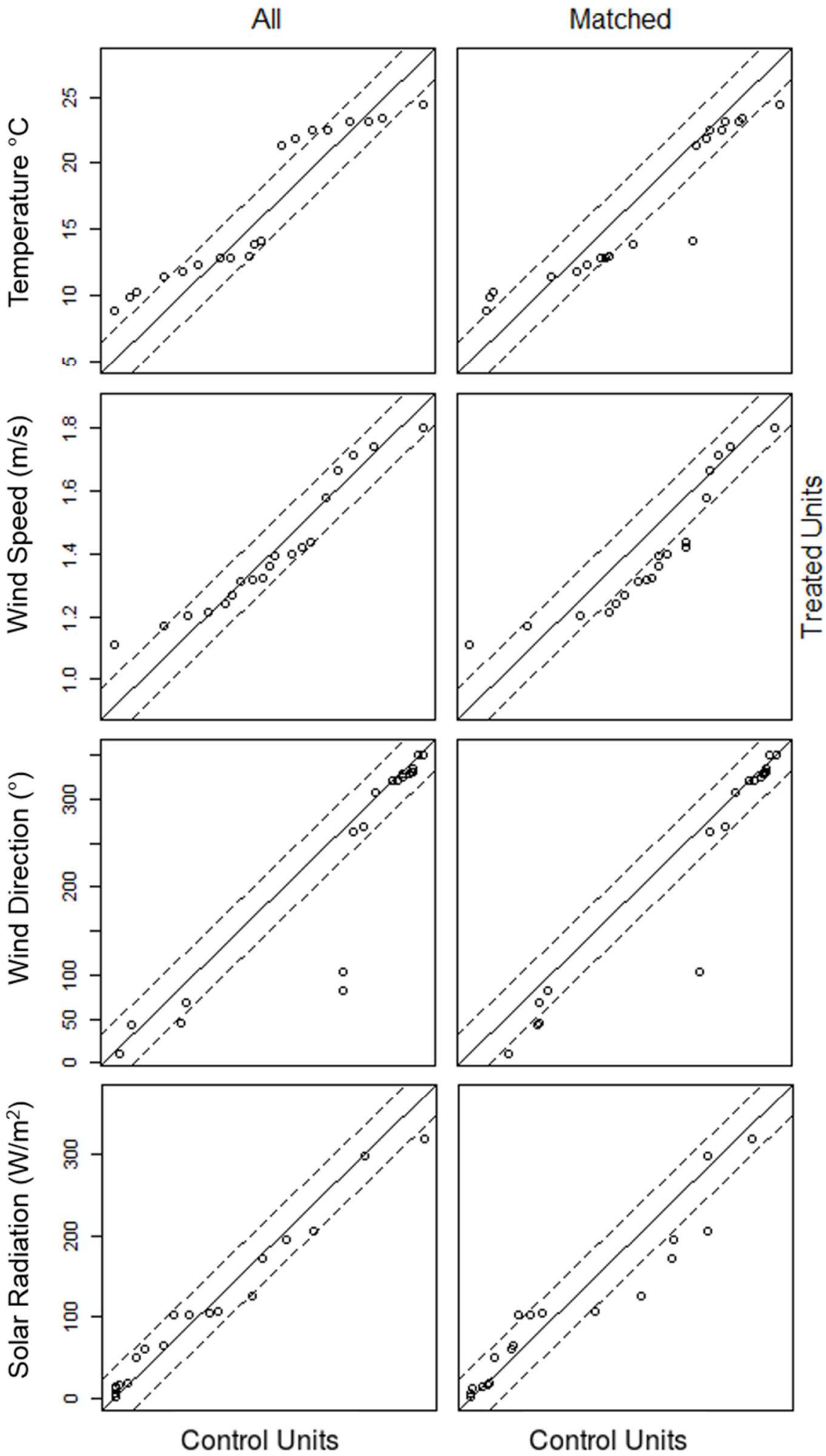

Figure B-6 QQ plots for unmatched and matched 15 min subset, Case Study 1 Evening. 

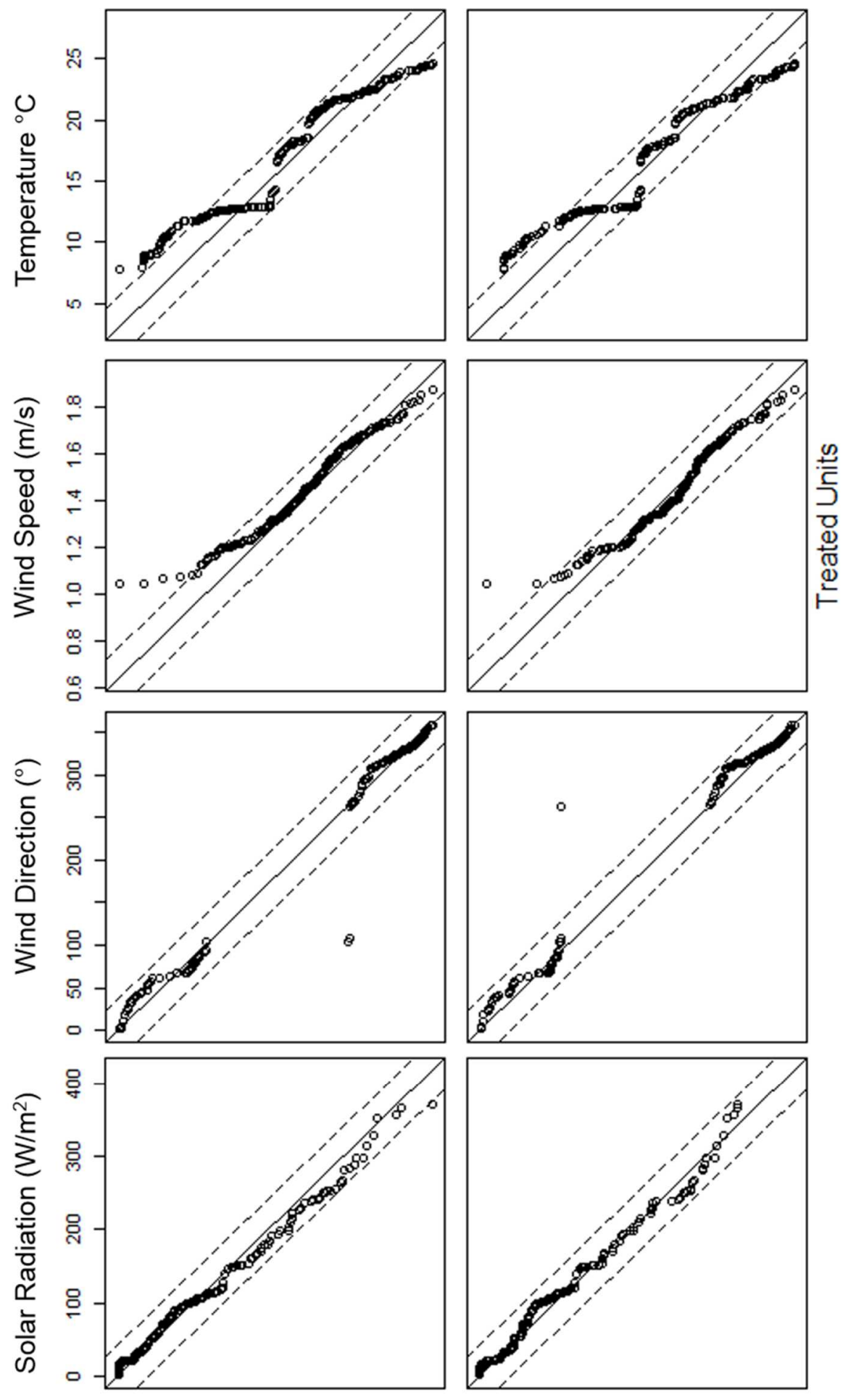

Control Units

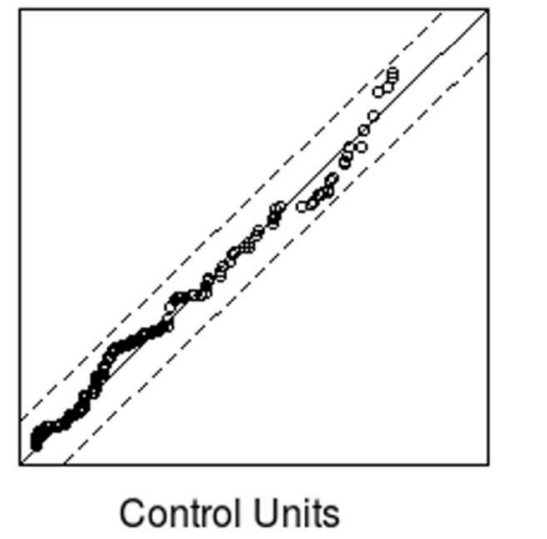

Figure B-7 QQ plots for unmatched and matched 5 min full dataset, Case Study 1 Evening. 

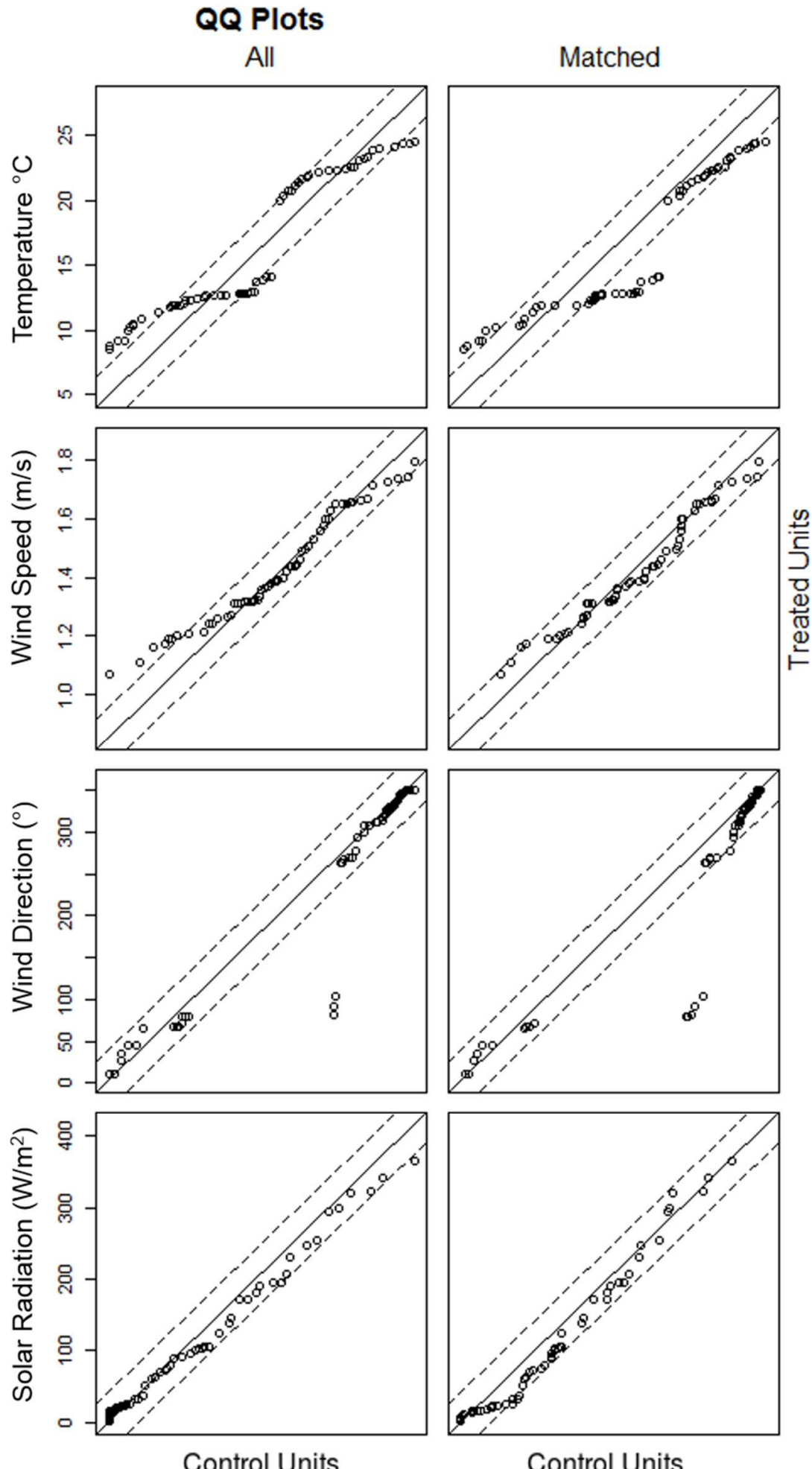

Figure B-8 QQ plots for unmatched and matched 15 min full dataset, Case Study 1 Evening. 


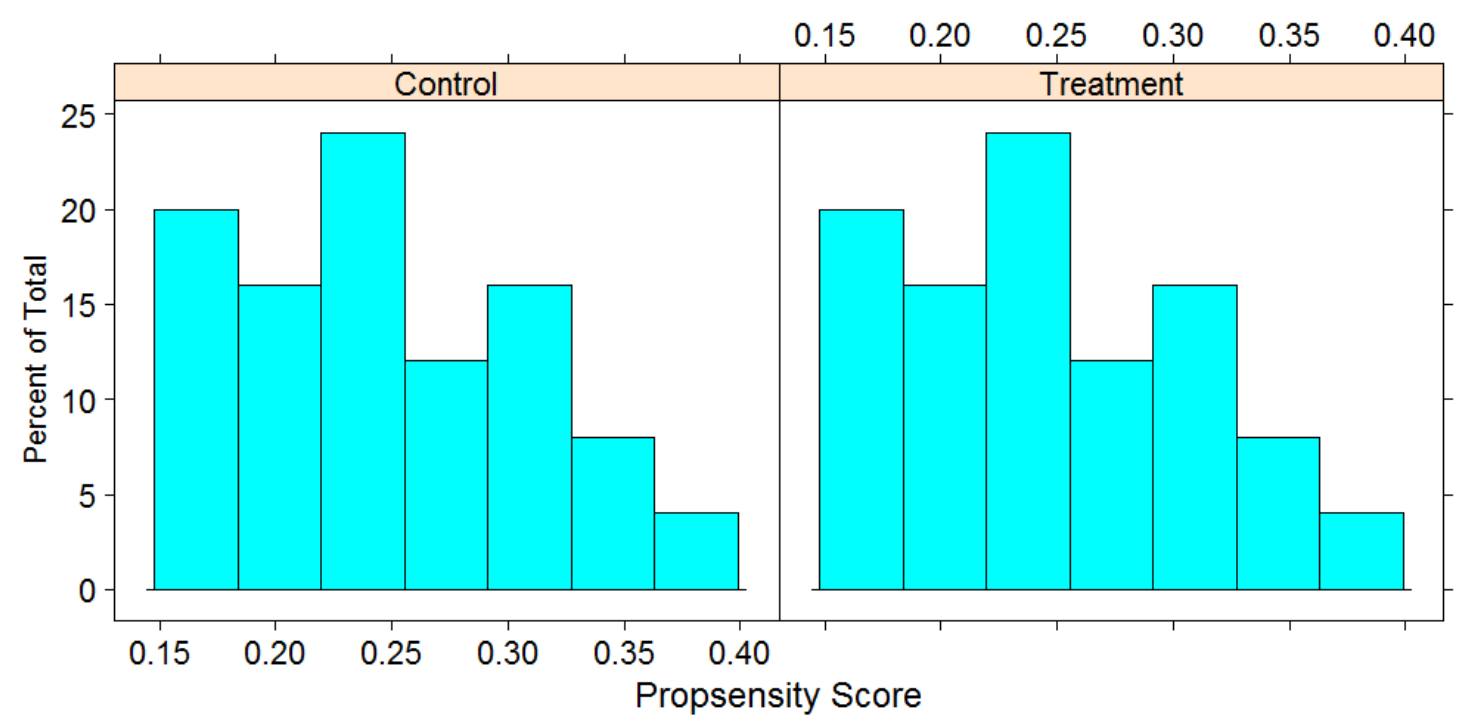

Figure B-9 Propensity score histograms for matched 5 min subset, Case Study 1 Evening.

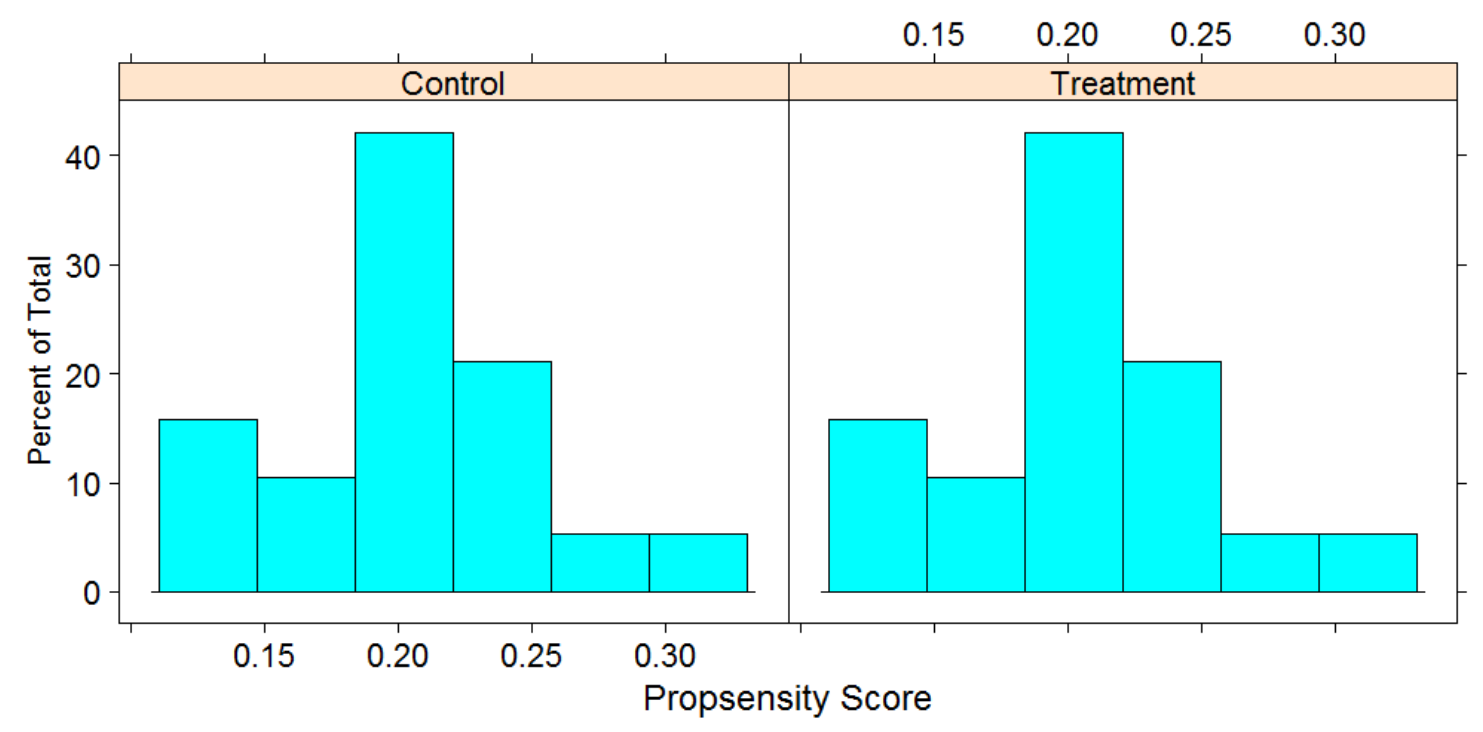

Figure B-10 Propensity score histograms for matched 15 min subset, Case Study 1 Evening. 


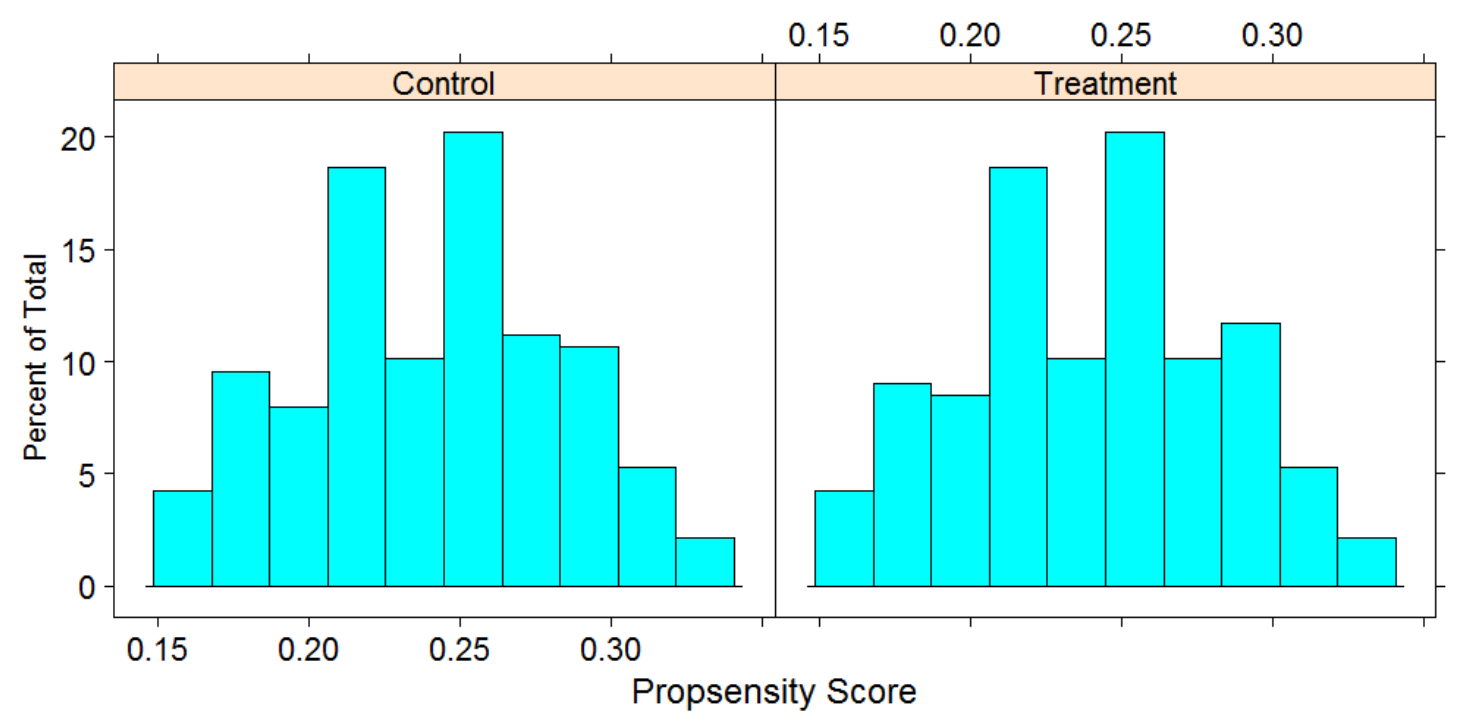

Figure B-11 Propensity score histograms for matched 5 min full dataset, Case Study 1 Evening.

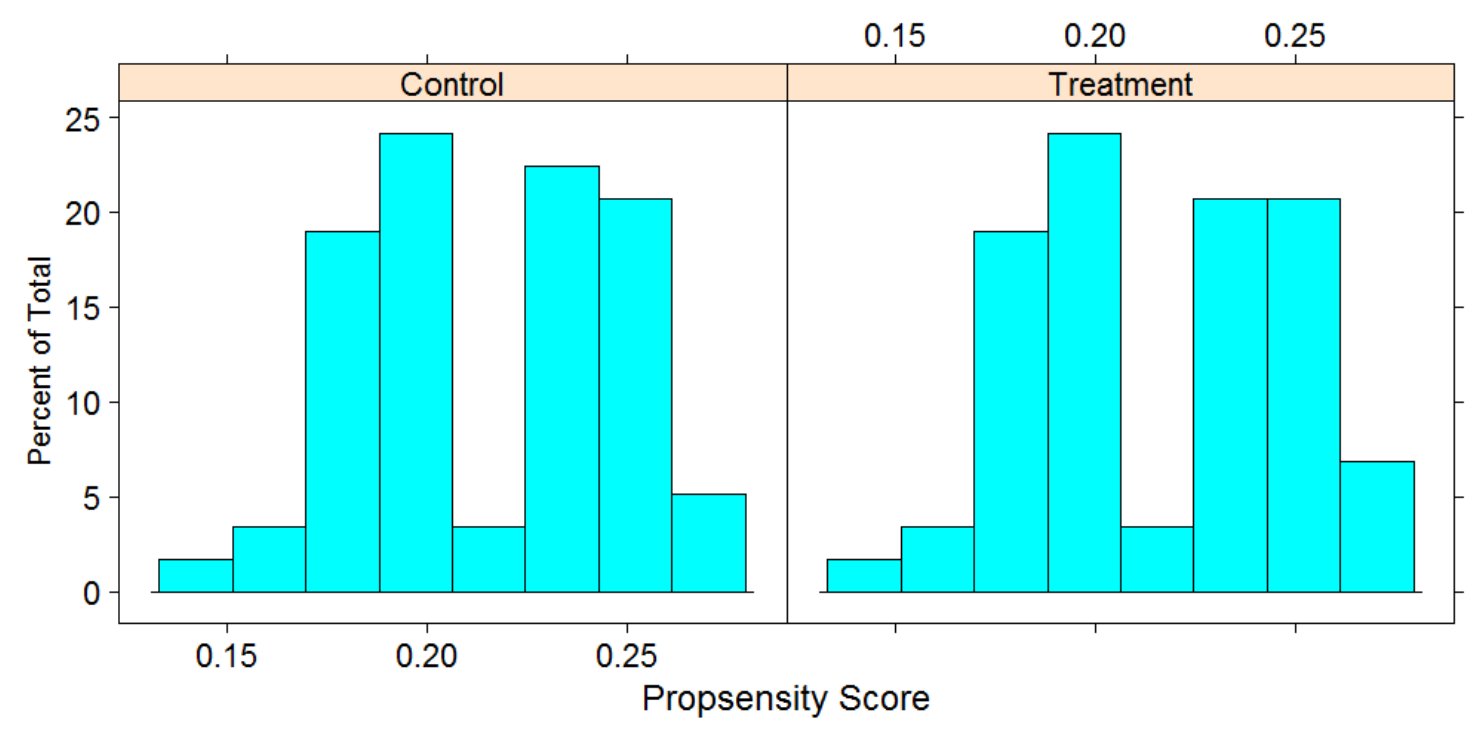

Figure B-12 Propensity score histograms for matched $15 \mathrm{~min}$ full dataset, Case Study 1 Evening. 
Table B-6 Case Study 1 Evening: CL and DS t-test results for unmatched and matched samples. Full datasets are in parentheses.

\begin{tabular}{|l|l|l|l|l|l|l|l|l|}
\hline Data Subset & $\begin{array}{l}\text { CL } \\
\text { Control }\end{array}$ & $\begin{array}{l}\text { CL } \\
\text { Trmt }\end{array}$ & $\begin{array}{l}\text { CL } \\
\text { t-value }\end{array}$ & $\begin{array}{l}\text { CL } \\
\text { p-value }\end{array}$ & $\begin{array}{l}\text { DS } \\
\text { Control }\end{array}$ & $\begin{array}{l}\text { DS } \\
\text { Trmt }\end{array}$ & $\begin{array}{l}\text { DS } \\
\text { t-value }\end{array}$ & $\begin{array}{l}\text { DS } \\
\text { p-value }\end{array}$ \\
\hline $\begin{array}{l}\text { Unmatched } \\
5 \text { min }\end{array}$ & 133 & 116 & 9.2 & $<0.01$ & 109 & 112 & -0.7 & 0.48 \\
$(133)$ & $(116)$ & $(26.4)$ & $(<0.01)$ & $(111)$ & $(115)$ & $(-2.9)$ & $(<0.01)$ \\
\hline $\begin{array}{l}\text { Matched } \\
5 \text { min }\end{array}$ & 131 & 116 & 4.4 & $<0.01$ & 107 & 112 & -0.9 & 0.36 \\
\hline $\begin{array}{l}\text { Unmatched } \\
15 \text { min }\end{array}$ & 133 & 116 & 10.1 & $<0.01$ & 113 & 116 & -0.7 & 0.5 \\
\hline $\begin{array}{l}\text { Matched } \\
15 \text { min }\end{array}$ & $(134)$ & $(116)$ & $(19.7)$ & $(<0.01)$ & $(114)$ & $(117)$ & $(-1.5)$ & $(0.15)$ \\
\hline
\end{tabular}


Table B-7 Case Study 1 Evening: Approach DS t-test results for unmatched and matched samples. Full datasets are in parentheses.

\begin{tabular}{|c|c|c|c|c|c|c|c|c|c|c|c|c|}
\hline $\begin{array}{l}\text { Data } \\
\text { Subset }\end{array}$ & $\begin{array}{l}\text { EB } \\
\text { Through } \\
\text { DS } \\
\text { Control }\end{array}$ & $\begin{array}{l}\text { EB } \\
\text { Through } \\
\text { DS } \\
\text { Trmt }\end{array}$ & $\begin{array}{l}\text { EB } \\
\text { Through } \\
\text { DS } \\
\text { t-value }\end{array}$ & $\begin{array}{l}\text { EB } \\
\text { Through } \\
\text { DS } \\
\text { p-value }\end{array}$ & $\begin{array}{l}\text { WB } \\
\text { Through } \\
\text { DS } \\
\text { Control }\end{array}$ & $\begin{array}{l}\text { WB } \\
\text { Through } \\
\text { DS } \\
\text { Trmt }\end{array}$ & $\begin{array}{l}\text { WB } \\
\text { Through } \\
\text { DS } \\
\text { t-value }\end{array}$ & $\begin{array}{l}\text { WB } \\
\text { Through } \\
\text { DS } \\
\text { p-value }\end{array}$ & $\begin{array}{l}\text { NB/SB } \\
\text { Through } \\
\text { Control }\end{array}$ & $\begin{array}{l}\text { NB/SB } \\
\text { Through } \\
\text { Trmt }\end{array}$ & $\begin{array}{l}\text { NB/SB } \\
\text { Through } \\
\text { t-value }\end{array}$ & $\begin{array}{l}\text { NB/SB } \\
\text { Through } \\
\text { p-value }\end{array}$ \\
\hline $\begin{array}{l}\text { Un- } \\
\text { matched } \\
5 \text { min }\end{array}$ & $\begin{array}{l}62 \\
(63)\end{array}$ & $\begin{array}{l}64 \\
(67)\end{array}$ & $\begin{array}{l}-0.7 \\
(-2.9)\end{array}$ & $\begin{array}{l}0.49 \\
(<0.01)\end{array}$ & $\begin{array}{l}52 \\
(52)\end{array}$ & $\begin{array}{l}54 \\
(52)\end{array}$ & $\begin{array}{l}-0.9 \\
(-0.4)\end{array}$ & $\begin{array}{l}0.4 \\
(0.72)\end{array}$ & $\begin{array}{l}71 \\
(71)\end{array}$ & $\begin{array}{l}70 \\
(72)\end{array}$ & $\begin{array}{l}0.1 \\
(-0.9)\end{array}$ & $\begin{array}{l}0.89 \\
(0.39)\end{array}$ \\
\hline $\begin{array}{l}\text { Matched } \\
5 \mathrm{~min}\end{array}$ & $\begin{array}{l}62 \\
(62)\end{array}$ & $\begin{array}{l}64 \\
(67)\end{array}$ & $\begin{array}{l}-0.6 \\
(-2.9)\end{array}$ & $\begin{array}{l}0.53 \\
(<0.01)\end{array}$ & $\begin{array}{l}53 \\
(52)\end{array}$ & $\begin{array}{l}54 \\
(52)\end{array}$ & $\begin{array}{l}-0.2 \\
(-0.5)\end{array}$ & $\begin{array}{l}0.82 \\
(0.6)\end{array}$ & $\begin{array}{l}74 \\
(70)\end{array}$ & $\begin{array}{l}70 \\
(72)\end{array}$ & $\begin{array}{l}0.8 \\
(-1.2)\end{array}$ & $\begin{array}{l}0.43 \\
(0.22)\end{array}$ \\
\hline $\begin{array}{l}\text { Un- } \\
\text { matched } \\
15 \mathrm{~min}\end{array}$ & $\begin{array}{l}63 \\
(64)\end{array}$ & $\begin{array}{l}70 \\
(66)\end{array}$ & $\begin{array}{l}-1.7 \\
(-1)\end{array}$ & $\begin{array}{l}0.09 \\
(0.33)\end{array}$ & $\begin{array}{l}51 \\
(52)\end{array}$ & $\begin{array}{l}56 \\
(52)\end{array}$ & $\begin{array}{l}-2.1 \\
(-0.4)\end{array}$ & $\begin{array}{l}0.05 \\
(0.69)\end{array}$ & $\begin{array}{l}71 \\
(72)\end{array}$ & $\begin{array}{l}74 \\
(73)\end{array}$ & $\begin{array}{l}-0.7 \\
(-0.6)\end{array}$ & $\begin{array}{l}0.51 \\
(0.52)\end{array}$ \\
\hline $\begin{array}{l}\text { Matched } \\
15 \mathrm{~min}\end{array}$ & $\begin{array}{l}62 \\
(64)\end{array}$ & $\begin{array}{l}70 \\
(66)\end{array}$ & $\begin{array}{l}-1.7 \\
(-0.7)\end{array}$ & $\begin{array}{l}0.11 \\
(0.48)\end{array}$ & $\begin{array}{l}49 \\
(52)\end{array}$ & $\begin{array}{l}56 \\
(52)\end{array}$ & $\begin{array}{l}-2.5 \\
(-0.12)\end{array}$ & $\begin{array}{l}0.02 \\
(0.9)\end{array}$ & $\begin{array}{l}72 \\
(72)\end{array}$ & $\begin{array}{l}74 \\
(73)\end{array}$ & $\begin{array}{l}-0.5 \\
(-0.6)\end{array}$ & $\begin{array}{l}0.61 \\
(0.55)\end{array}$ \\
\hline
\end{tabular}

$\stackrel{N}{\perp}$ 
Table B-8 Case Study 1 Evening: Normalized NO and $\mathrm{NO}_{2}$ t-test results for unmatched and matched samples. Full datasets are in parentheses.

\begin{tabular}{|c|c|c|c|c|c|c|c|c|}
\hline Data Subset & $\begin{array}{l}\text { N- NO } \\
\text { Control }\end{array}$ & $\begin{array}{l}\text { N- NO } \\
\text { Trmt }\end{array}$ & $\begin{array}{l}\mathrm{N}-\mathrm{NO} \\
\mathrm{t} \text {-value }\end{array}$ & $\begin{array}{l}\text { N- NO } \\
\text { p-value }\end{array}$ & $\begin{array}{l}\mathrm{N}-\mathrm{NO}_{2} \\
\text { Control }\end{array}$ & $\begin{array}{l}\mathrm{N}-\mathrm{NO}_{2} \\
\text { Trmt }\end{array}$ & $\begin{array}{l}\mathrm{N}-\mathrm{NO}_{2} \\
\text { t-value }\end{array}$ & $\begin{array}{l}\mathrm{N}-\mathrm{NO}_{2} \\
\text { p-value }\end{array}$ \\
\hline $\begin{array}{l}\text { Unmatched } \\
5 \mathrm{~min}\end{array}$ & $\begin{array}{l}2.2 \\
(2.2)\end{array}$ & $\begin{array}{l}2.4 \\
(2.3)\end{array}$ & $\begin{array}{l}-2.2 \\
(-3.2)\end{array}$ & $\begin{array}{l}0.03 \\
(<0.01)\end{array}$ & $\begin{array}{l}1.4 \\
(1.3)\end{array}$ & $\begin{array}{l}1.3 \\
(1.4)\end{array}$ & $\begin{array}{l}0.6 \\
(-1.3)\end{array}$ & $\begin{array}{l}0.59 \\
(0.21)\end{array}$ \\
\hline $\begin{array}{l}\text { Matched } \\
5 \mathrm{~min}\end{array}$ & $\begin{array}{l}2.3 \\
(2.2)\end{array}$ & $\begin{array}{l}2.4 \\
(2.3)\end{array}$ & $\begin{array}{l}-0.9 \\
(-3.1)\end{array}$ & $\begin{array}{l}0.4 \\
(<0.01)\end{array}$ & $\begin{array}{l}1.4 \\
(1.3)\end{array}$ & $\begin{array}{l}1.3 \\
(1.4)\end{array}$ & $\begin{array}{l}0.6 \\
(-1.8)\end{array}$ & $\begin{array}{l}0.53 \\
(0.08)\end{array}$ \\
\hline $\begin{array}{l}\text { Unmatched } \\
15 \mathrm{~min}\end{array}$ & $\begin{array}{l}2.2 \\
(2.2)\end{array}$ & $\begin{array}{l}2.5 \\
(2.3)\end{array}$ & $\begin{array}{l}-2.3 \\
(-1.5)\end{array}$ & $\begin{array}{l}0.03 \\
(0.15)\end{array}$ & $\begin{array}{l}1.3 \\
(1.4)\end{array}$ & $\begin{array}{l}1.4 \\
(1.4)\end{array}$ & $\begin{array}{l}-0.4 \\
(0.03)\end{array}$ & $\begin{array}{l}0.69 \\
(0.97)\end{array}$ \\
\hline $\begin{array}{l}\text { Matched } \\
15 \mathrm{~min}\end{array}$ & $\begin{array}{l}2.2 \\
(2.2)\end{array}$ & $\begin{array}{l}2.5 \\
(2.3)\end{array}$ & $\begin{array}{l}-2.8 \\
(-2.2)\end{array}$ & $\begin{array}{l}<0.01 \\
(0.03)\end{array}$ & $\begin{array}{l}1.4 \\
(1.4)\end{array}$ & $\begin{array}{l}1.4 \\
(1.3)\end{array}$ & $\begin{array}{l}-0.1 \\
(0.9)\end{array}$ & $\begin{array}{l}0.89 \\
(0.36)\end{array}$ \\
\hline
\end{tabular}


Table B-9 Case Study 1 Evening: Roadside $\mathrm{NO}$ and $\mathrm{NO}_{2}$ (cuberoot transformed) t-test results for unmatched and matched samples. Full datasets are in parentheses.

\begin{tabular}{|l|l|l|l|l|l|l|l|l|}
\hline Data Subset & $\begin{array}{l}\text { CR- NO } \\
\text { Control }\end{array}$ & $\begin{array}{l}\text { CR- NO } \\
\text { Trmt }\end{array}$ & $\begin{array}{l}\text { CR- NO } \\
\text { t-value }\end{array}$ & $\begin{array}{l}\text { CR- NO } \\
\text { p-value }\end{array}$ & $\begin{array}{l}\text { CR- } \mathrm{NO}_{2} \\
\text { Control }\end{array}$ & $\begin{array}{l}\mathrm{CR}-\mathrm{NO}_{2} \\
\text { Trmt }\end{array}$ & $\begin{array}{l}\text { CR- } \mathrm{NO}_{2} \\
\text { t-value }\end{array}$ & $\begin{array}{l}\mathrm{CR}-\mathrm{NO}_{2} \\
\text { p-value }\end{array}$ \\
\hline $\begin{array}{l}\text { Unmatched } \\
5 \mathrm{~min}\end{array}$ & 2.7 & 2.7 & 0.2 & 0.86 & 2.7 & 2.6 & 0.8 & 0.45 \\
$(2.7)$ & $(2.7)$ & $(1.7)$ & $(0.08)$ & $(2.7)$ & $(2.6)$ & $(1.3)$ & $(0.19)$ \\
\hline $\begin{array}{l}\text { Matched } \\
5 \text { min }\end{array}$ & 2.9 & 2.7 & 0.9 & 0.38 & 2.7 & 2.6 & 1.2 & 0.22 \\
\hline $\begin{array}{l}\text { Unmatched } \\
15 \text { min }\end{array}$ & 2.8 & $(2.6)$ & $(-0.4)$ & $(0.67)$ & $(2.6)$ & $(2.6)$ & $(-0.7)$ & $(0.51)$ \\
\hline $\begin{array}{l}\text { Matched } \\
15 \text { min }\end{array}$ & 2.6 & $(2.7)$ & $(1.8)$ & $(0.07)$ & $(2.7)$ & $(2.6)$ & $(1.1)$ & $(0.27)$ \\
\hline
\end{tabular}


Table B-10 Case Study 1 Evening: Background $\mathrm{NO}$ and $\mathrm{NO}_{2}$ (cuberoot transformed) t-test results for unmatched and matched samples. Full datasets are in parentheses.

\begin{tabular}{|l|l|l|l|l|l|l|l|l|}
\hline Data Subset & $\begin{array}{l}\text { DEQ NO } \\
\text { Control }\end{array}$ & $\begin{array}{l}\text { DEQ NO } \\
\text { Trmt }\end{array}$ & $\begin{array}{l}\text { DEQ NO } \\
\text { t-value }\end{array}$ & $\begin{array}{l}\text { DEQ NO } \\
\text {-value }\end{array}$ & $\begin{array}{l}\text { DEQ NO } 2 \\
\text { Control }\end{array}$ & $\begin{array}{l}\text { DEQ NO } 2 \\
\text { Trmt }\end{array}$ & $\begin{array}{l}\text { DEQ NO } 2 \\
\text { t-value }\end{array}$ & $\begin{array}{l}\mathrm{DEQ} \mathrm{NO}_{2} \\
\text {-value }\end{array}$ \\
\hline $\begin{array}{l}\text { Unmatched } \\
5 \text { min }\end{array}$ & 1.3 & 1.1 & 3.2 & $<0.01$ & 2 & 2 & 0.8 & 0.42 \\
$(1.3)$ & $(1.2)$ & $(8.3)$ & $(<0.01)$ & $(2)$ & $(1.9)$ & $(4.5)$ & $(<0.01)$ \\
\hline $\begin{array}{l}\text { Matched } \\
5 \text { min }\end{array}$ & 1.2 & 1.1 & 2.6 & 0.01 & 2 & 2 & 0.8 & 0.45 \\
$(1.2)$ & $(1.1)$ & $(4.5)$ & $(<0.01)$ & $(2)$ & $(1.9)$ & $(1.9)$ & $(0.06)$ \\
\hline $\begin{array}{l}\text { Unmatched } \\
15 \text { min }\end{array}$ & 1.3 & 1.1 & 3.4 & $<0.01$ & 2 & 2 & 1 & $(2)$ \\
$(1.3)$ & $(1.2)$ & $(4.8)$ & $(<0.01)$ & $(2)$ & $(1.8)$ & $(0.07)$ \\
\hline $\begin{array}{l}\text { Matched } \\
15 \text { min }\end{array}$ & 1.2 & 1.1 & 2 & 0.05 & 2 & 2 & 0.2 & 0.82 \\
\hline
\end{tabular}



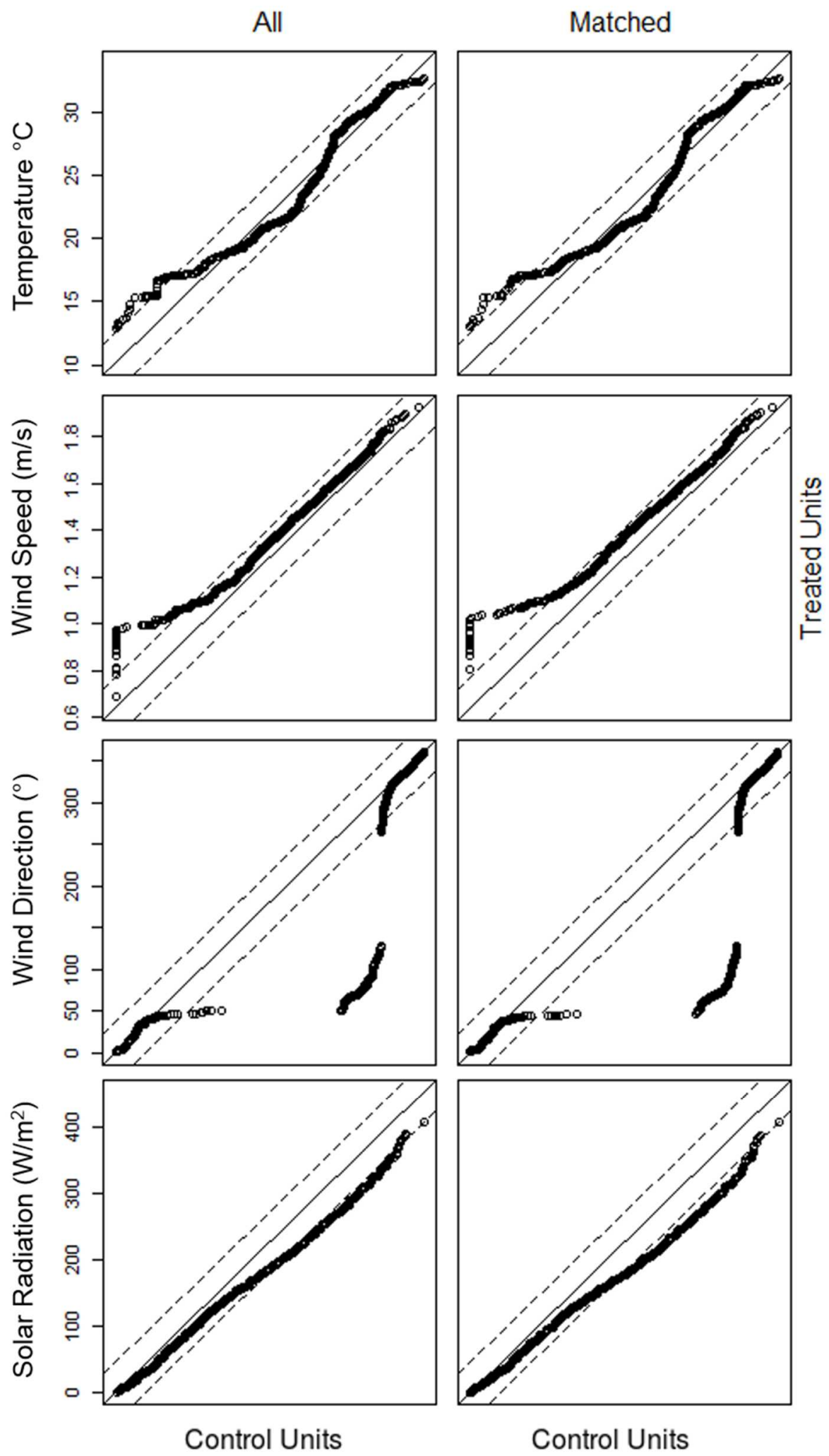

Figure B-13 QQ plots for unmatched and matched 5 min subset, Case Study 2 Evening. 

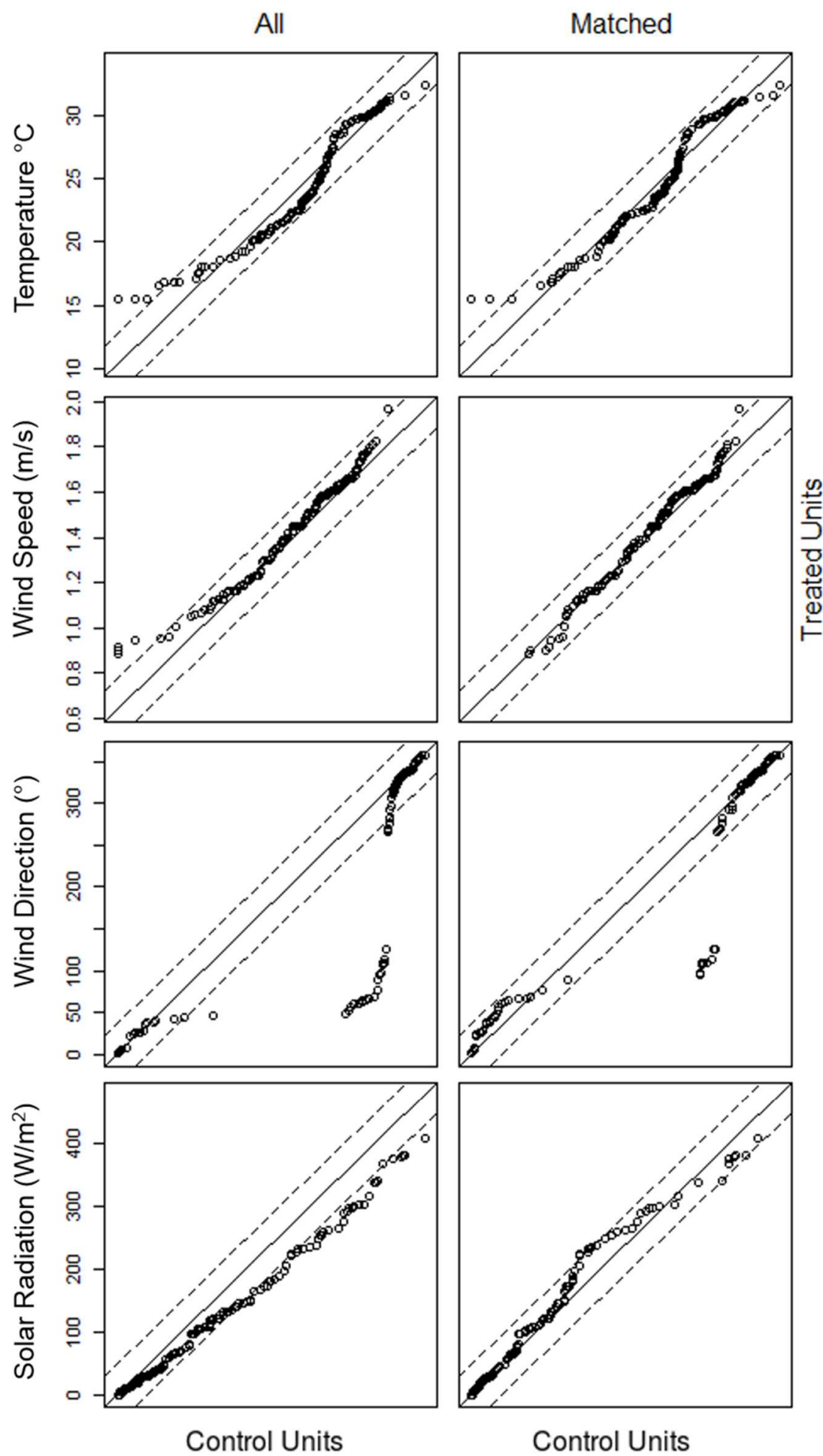

Figure B-14 QQ plots for unmatched and matched 15 min subset, Case Study 2 Evening. 

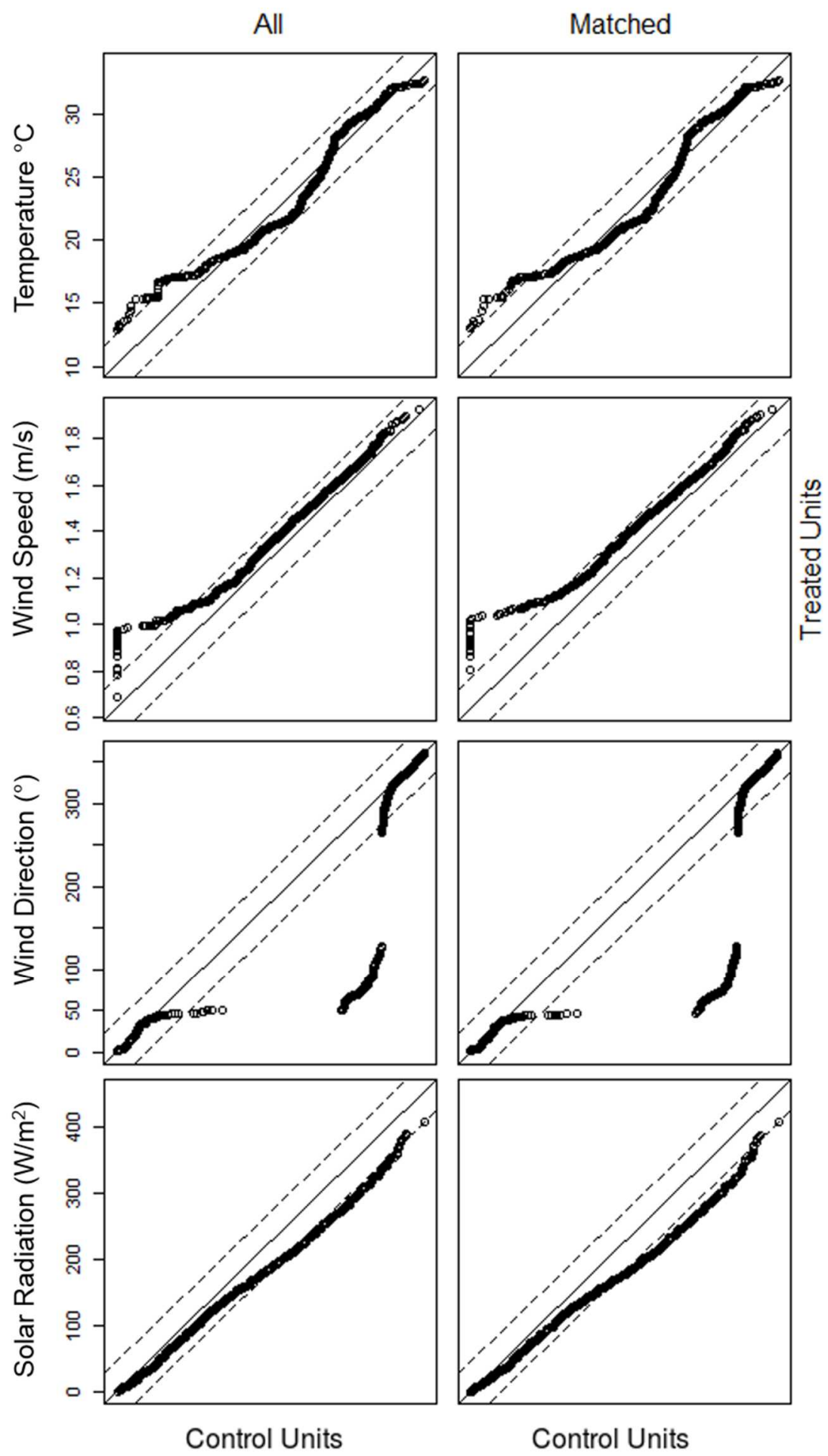

Figure B-15 QQ plots for unmatched and matched 5 min full dataset, Case Study 2 Evening. 

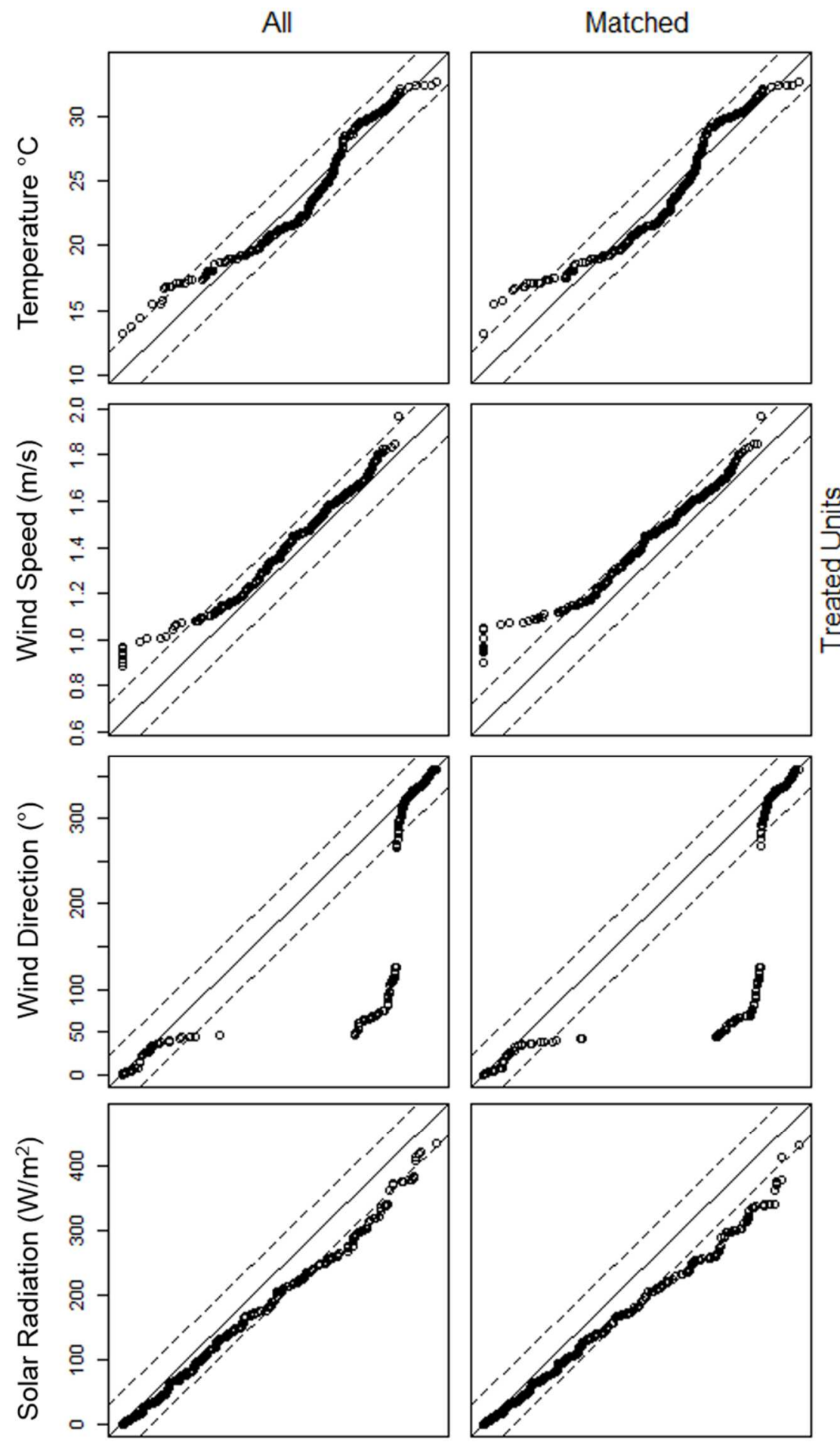

Control Units

Control Units

Figure B-16 QQ plots for unmatched and matched 15 min full dataset, Case Study 2 Evening. 


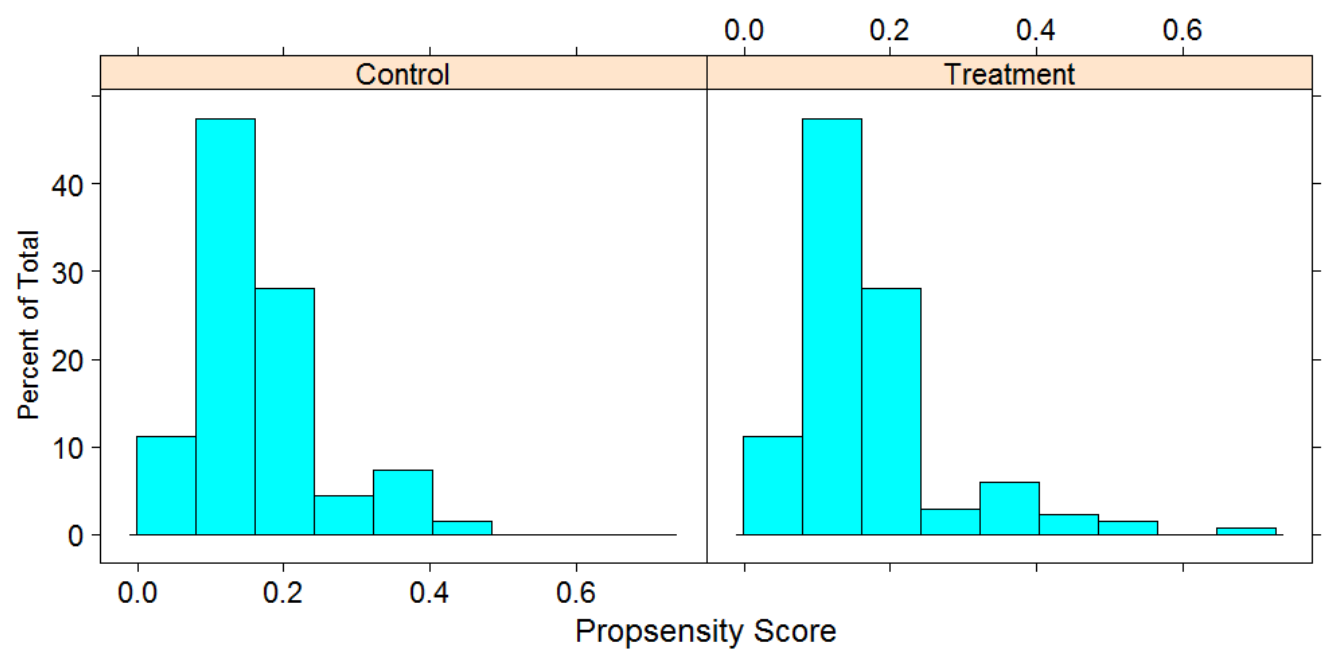

Figure B-17 Propensity score histograms for matched 5min subset, Case Study 2 Evening.

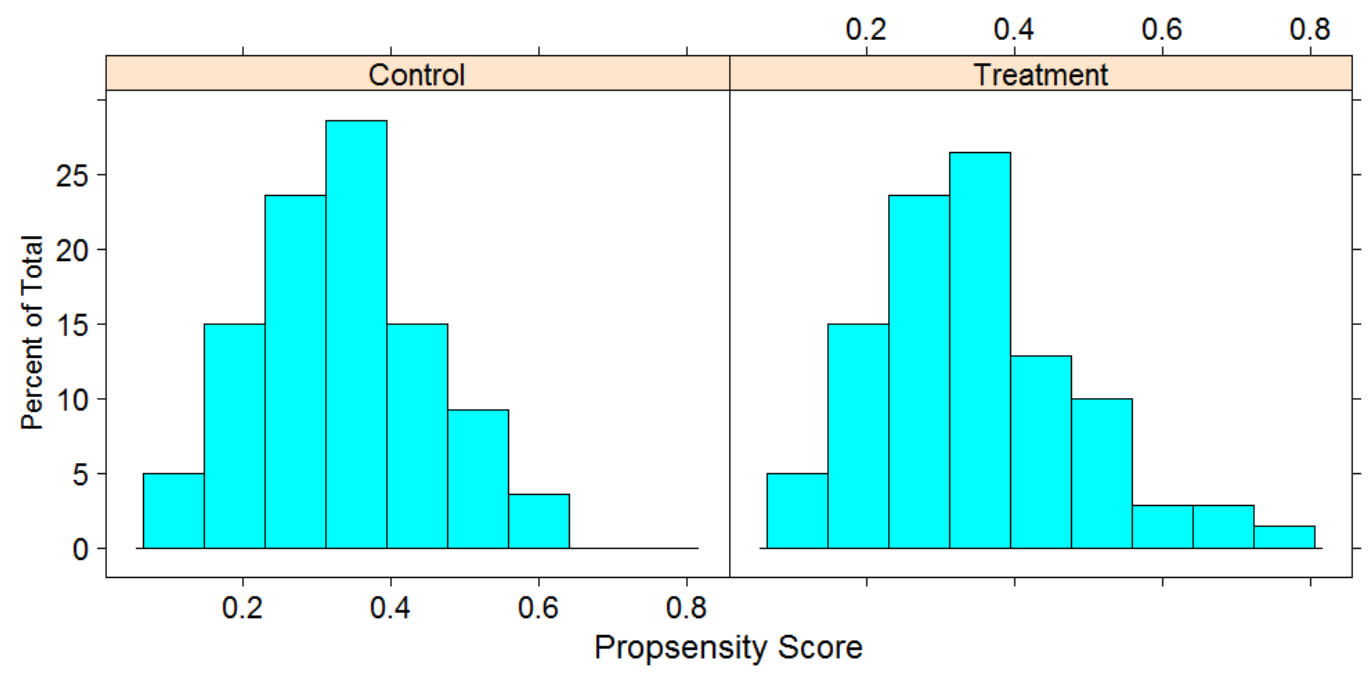

Figure B-18 Propensity score histograms for matched 15min subset, Case Study 2 Evening. 


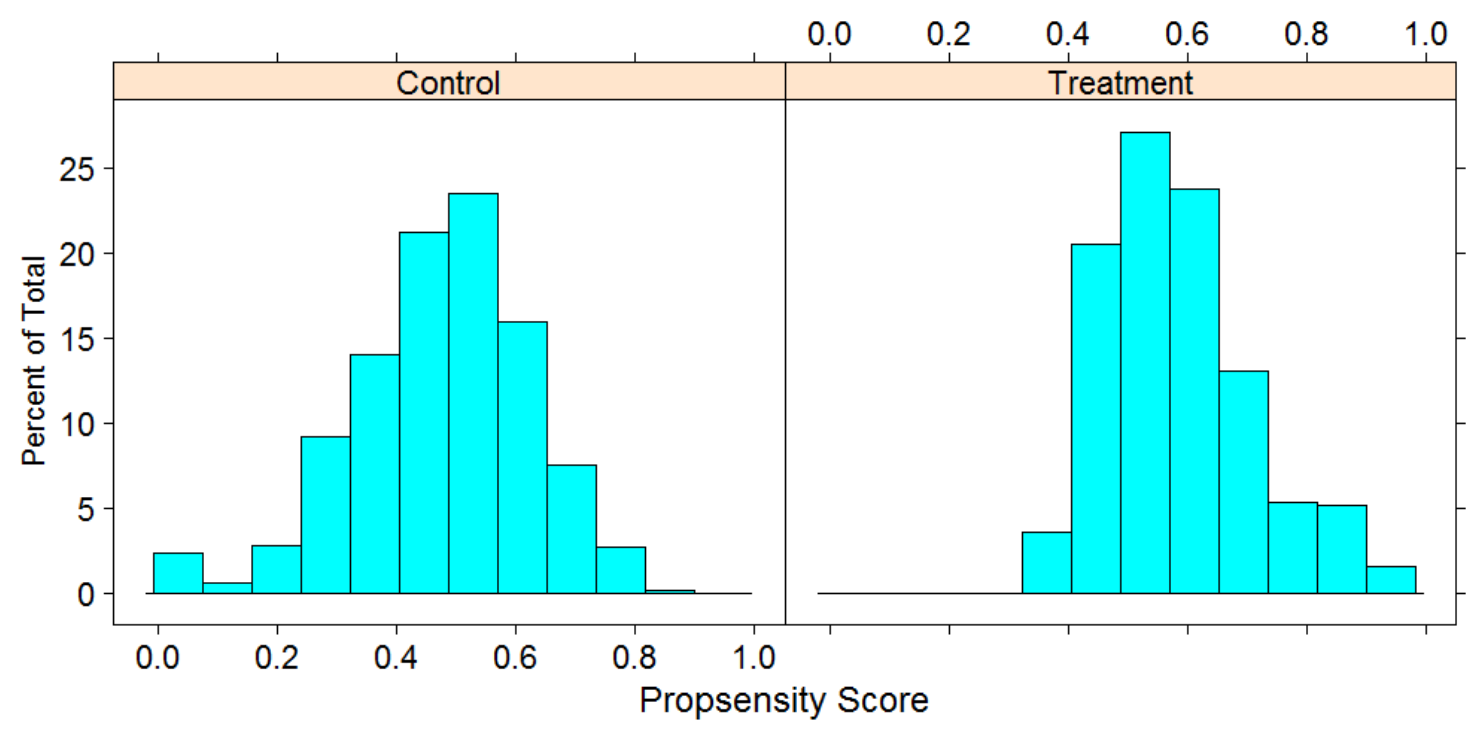

Figure B-19 Propensity score histograms for matched $5 \mathrm{~min}$ full dataset, Case Study 2 Evening.

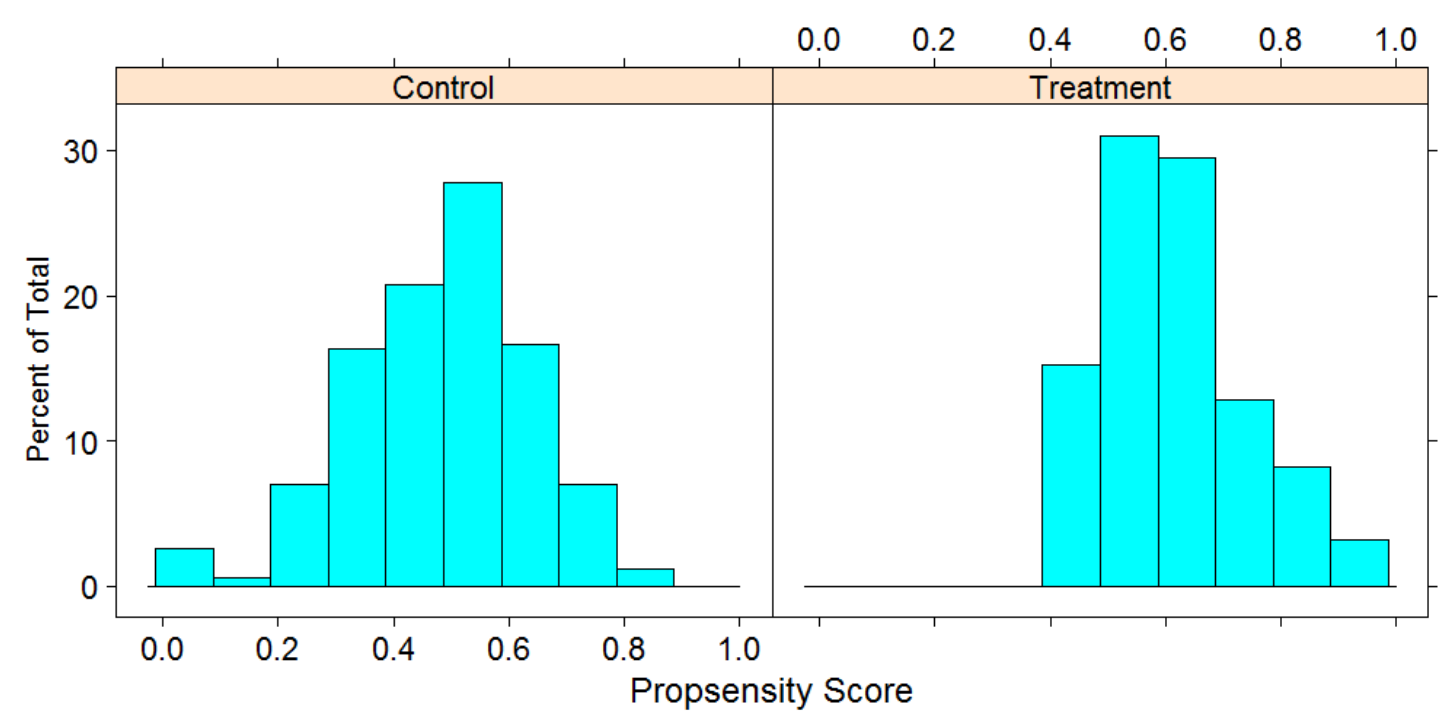

Figure B-20 Propensity score histograms for matched 15min full dataset, Case Study 2 Evening. 
Table B-11 Case Study 2 Evening: CL and DS t-test results for unmatched and matched samples. Full datasets are in parentheses.

\begin{tabular}{|c|c|c|c|c|c|c|c|c|}
\hline Data Subset & $\begin{array}{l}\text { CL } \\
\text { Control }\end{array}$ & $\begin{array}{l}\text { CL } \\
\text { Trmt }\end{array}$ & $\begin{array}{l}\text { CL } \\
\text { t-value }\end{array}$ & $\begin{array}{l}\text { CL } \\
\text { p-value }\end{array}$ & $\begin{array}{l}\text { DS } \\
\text { Control }\end{array}$ & $\begin{array}{l}\text { DS } \\
\text { Trmt }\end{array}$ & $\begin{array}{l}\text { DS } \\
\text { t-value }\end{array}$ & $\begin{array}{l}\text { DS } \\
\text { p-value }\end{array}$ \\
\hline $\begin{array}{l}\text { Unmatched } \\
5 \mathrm{~min}\end{array}$ & $\begin{array}{l}134 \\
(134)\end{array}$ & $\begin{array}{l}124 \\
(124)\end{array}$ & $\begin{array}{l}19.5 \\
(25)\end{array}$ & $\begin{array}{l}<0.01 \\
(<0.01)\end{array}$ & $\begin{array}{l}112 \\
(112)\end{array}$ & $\begin{array}{l}111 \\
(113)\end{array}$ & $\begin{array}{l}0.7 \\
(-0.6)\end{array}$ & $\begin{array}{l}0.48 \\
(0.58)\end{array}$ \\
\hline $\begin{array}{l}\text { Matched } \\
5 \mathrm{~min}\end{array}$ & $\begin{array}{l}133 \\
(134)\end{array}$ & $\begin{array}{l}124 \\
(124)\end{array}$ & $\begin{array}{l}7.2 \\
(25)\end{array}$ & $\begin{array}{l}<0.01 \\
(<0.01)\end{array}$ & $\begin{array}{l}106 \\
(112)\end{array}$ & $\begin{array}{l}111 \\
(112)\end{array}$ & $\begin{array}{l}-1.8 \\
(-0.2)\end{array}$ & $\begin{array}{l}0.08 \\
(0.81)\end{array}$ \\
\hline $\begin{array}{l}\text { Unmatched } \\
15 \mathrm{~min}\end{array}$ & $\begin{array}{l}135 \\
(135)\end{array}$ & $\begin{array}{l}124 \\
(124)\end{array}$ & $\begin{array}{l}20.5 \\
(22)\end{array}$ & $\begin{array}{l}<0.01 \\
(<0.01)\end{array}$ & $\begin{array}{l}115 \\
(115)\end{array}$ & $\begin{array}{l}114 \\
(116)\end{array}$ & $\begin{array}{l}0.7 \\
(-0.6)\end{array}$ & $\begin{array}{l}0.47 \\
(0.55)\end{array}$ \\
\hline $\begin{array}{l}\text { Matched } \\
15 \mathrm{~min}\end{array}$ & $\begin{array}{l}134 \\
(135)\end{array}$ & $\begin{array}{l}124 \\
(124)\end{array}$ & $\begin{array}{l}12 \\
(22)\end{array}$ & $\begin{array}{l}<0.01 \\
(<0.01)\end{array}$ & $\begin{array}{l}111 \\
(115)\end{array}$ & $\begin{array}{l}114 \\
(115)\end{array}$ & $\begin{array}{l}-1.2 \\
(-0.02)\end{array}$ & $\begin{array}{l}0.24 \\
(0.98)\end{array}$ \\
\hline
\end{tabular}


Table B-12 Case Study 2 Evening: Approach DS t-test results for unmatched and matched samples. Full datasets are in parentheses.

\begin{tabular}{|c|c|c|c|c|c|c|c|c|c|c|c|c|}
\hline $\begin{array}{l}\text { Data } \\
\text { Subset }\end{array}$ & $\begin{array}{l}\text { EB } \\
\text { Through } \\
\text { DS } \\
\text { Control }\end{array}$ & $\begin{array}{l}\text { EB } \\
\text { Through } \\
\text { DS } \\
\text { Trmt }\end{array}$ & $\begin{array}{l}\text { EB } \\
\text { Through } \\
\text { DS } \\
\text { t-value }\end{array}$ & $\begin{array}{l}\text { EB } \\
\text { Through } \\
\text { DS } \\
\text { p-value }\end{array}$ & $\begin{array}{l}\text { WB } \\
\text { Through } \\
\text { DS } \\
\text { Control }\end{array}$ & $\begin{array}{l}\text { WB } \\
\text { Through } \\
\text { DS } \\
\text { Trmt }\end{array}$ & $\begin{array}{l}\text { WB } \\
\text { Through } \\
\text { DS } \\
\text { t-value }\end{array}$ & $\begin{array}{l}\text { WB } \\
\text { Through } \\
\text { DS } \\
\text { p-value }\end{array}$ & $\begin{array}{l}\text { NB/SB } \\
\text { Through } \\
\text { Control }\end{array}$ & $\begin{array}{l}\text { NB/SB } \\
\text { Through } \\
\text { Trmt }\end{array}$ & $\begin{array}{l}\text { NB/SB } \\
\text { Through } \\
\text { t-value }\end{array}$ & $\begin{array}{l}\text { NB/SB } \\
\text { Through } \\
\text { p-value }\end{array}$ \\
\hline $\begin{array}{l}\text { Un- } \\
\text { Matched } \\
5 \text { min } \\
\text { Matched } \\
5 \text { min }\end{array}$ & $\begin{array}{l}68 \\
(68) \\
62 \\
(68)\end{array}$ & $\begin{array}{l}64 \\
(65) \\
64 \\
(65)\end{array}$ & $\begin{array}{l}2.3 \\
(2.8) \\
-1.15 \\
(3.3)\end{array}$ & $\begin{array}{l}0.02 \\
(<0.01) \\
0.25 \\
(<0.01)\end{array}$ & $\begin{array}{l}53 \\
(53) \\
52 \\
(53)\end{array}$ & $\begin{array}{l}54 \\
(56) \\
54 \\
(56)\end{array}$ & $\begin{array}{l}-1.6 \\
(-6.6) \\
-1.9 \\
(-6.2)\end{array}$ & $\begin{array}{l}0.11 \\
(<0.01) \\
0.05 \\
(<0.01)\end{array}$ & $\begin{array}{l}76 \\
(76) \\
72 \\
(75)\end{array}$ & $\begin{array}{l}74 \\
(74) \\
74 \\
(73)\end{array}$ & $\begin{array}{l}0.9 \\
(2.5) \\
-1.3 \\
(-1.5)\end{array}$ & $\begin{array}{l}0.38 \\
(0.01) \\
0.21 \\
(0.14)\end{array}$ \\
\hline $\begin{array}{l}\text { Un- } \\
\text { matched } \\
15 \text { min }\end{array}$ & $\begin{array}{l}69 \\
(69)\end{array}$ & $\begin{array}{l}66 \\
(67)\end{array}$ & $\begin{array}{l}1.5 \\
(1.5)\end{array}$ & $\begin{array}{l}0.13 \\
(0.13)\end{array}$ & $\begin{array}{l}53 \\
(53)\end{array}$ & $\begin{array}{l}56 \\
(57)\end{array}$ & $\begin{array}{l}-3.1 \\
(-4.7)\end{array}$ & $\begin{array}{l}<0.01 \\
(<0.01)\end{array}$ & $\begin{array}{l}77 \\
(77)\end{array}$ & $\begin{array}{l}74 \\
(74)\end{array}$ & $\begin{array}{l}2.1 \\
(2.3)\end{array}$ & $\begin{array}{l}0.03 \\
(0.02)\end{array}$ \\
\hline $\begin{array}{l}\text { Matched } \\
15 \mathrm{~min}\end{array}$ & $\begin{array}{l}63 \\
(69)\end{array}$ & $\begin{array}{l}66 \\
(66)\end{array}$ & $\begin{array}{l}-1.4 \\
(2.1)\end{array}$ & $\begin{array}{l}0.17 \\
(0.03)\end{array}$ & $\begin{array}{l}52 \\
(53)\end{array}$ & $\begin{array}{l}56 \\
(56)\end{array}$ & $\begin{array}{l}-4 \\
(-4)\end{array}$ & $\begin{array}{l}<0.01 \\
(<0.01)\end{array}$ & $\begin{array}{l}75 \\
(77)\end{array}$ & $\begin{array}{l}74 \\
(74)\end{array}$ & $\begin{array}{l}0.8 \\
(2.7)\end{array}$ & $\begin{array}{l}0.42 \\
(0.01)\end{array}$ \\
\hline
\end{tabular}

$\bar{u}$ 
Table B-13 Case Study 2 Evening: Normalized $\mathrm{NO}$ and $\mathrm{NO}_{2}$ t-test results for unmatched and matched samples. Full datasets are in parentheses.

\begin{tabular}{|c|c|c|c|c|c|c|c|c|}
\hline Data Subset & $\begin{array}{l}\text { N- NO } \\
\text { Control }\end{array}$ & $\begin{array}{l}\text { N- NO } \\
\text { Trmt }\end{array}$ & $\begin{array}{l}\mathrm{N}-\mathrm{NO} \\
\mathrm{t} \text {-value }\end{array}$ & $\begin{array}{l}\text { N- NO } \\
\text { p-value }\end{array}$ & $\begin{array}{l}\mathrm{N}-\mathrm{NO}_{2} \\
\text { Control }\end{array}$ & $\begin{array}{l}\mathrm{N}-\mathrm{NO}_{2} \\
\text { Trmt }\end{array}$ & $\begin{array}{l}\mathrm{N}-\mathrm{NO}_{2} \\
\text { t-value }\end{array}$ & $\begin{array}{l}\mathrm{N}-\mathrm{NO}_{2} \\
\text { p-value }\end{array}$ \\
\hline $\begin{array}{l}\text { Unmatched } \\
5 \mathrm{~min}\end{array}$ & $\begin{array}{l}2.22 \\
(2.22)\end{array}$ & $\begin{array}{l}2.93 \\
(2.86)\end{array}$ & $\begin{array}{l}-7.5 \\
(-12.4)\end{array}$ & $\begin{array}{l}<0.01 \\
(<0.01)\end{array}$ & $\begin{array}{l}1.29 \\
(1.3)\end{array}$ & $\begin{array}{l}1.37 \\
(1.38)\end{array}$ & $\begin{array}{l}-2.8 \\
(-6.5)\end{array}$ & $\begin{array}{l}<0.01 \\
(<0.01)\end{array}$ \\
\hline $\begin{array}{l}\text { Matched } \\
5 \mathrm{~min}\end{array}$ & $\begin{array}{l}2.09 \\
(2.22)\end{array}$ & $\begin{array}{l}2.93 \\
(2.83)\end{array}$ & $\begin{array}{l}-8.2 \\
(-12.1)\end{array}$ & $\begin{array}{l}<0.01 \\
(<0.01)\end{array}$ & $\begin{array}{l}1.25 \\
(1.3)\end{array}$ & $\begin{array}{l}1.37 \\
(1.38)\end{array}$ & $\begin{array}{l}-3.5 \\
(-6.3)\end{array}$ & $\begin{array}{l}<0.01 \\
(<0.01)\end{array}$ \\
\hline $\begin{array}{l}\text { Unmatched } \\
15 \mathrm{~min}\end{array}$ & $\begin{array}{l}2.29 \\
(2.29)\end{array}$ & $\begin{array}{l}2.9 \\
(2.82)\end{array}$ & $\begin{array}{l}-7.3 \\
(-10.3)\end{array}$ & $\begin{array}{l}<0.01 \\
(<0.01)\end{array}$ & $\begin{array}{l}1.34 \\
(1.34)\end{array}$ & $\begin{array}{l}1.39 \\
(1.42)\end{array}$ & $\begin{array}{l}-1.9 \\
(-3.9)\end{array}$ & $\begin{array}{l}0.06 \\
(<0.01)\end{array}$ \\
\hline $\begin{array}{l}\text { Matched } \\
15 \mathrm{~min}\end{array}$ & $\begin{array}{l}2.21 \\
(2.28)\end{array}$ & $\begin{array}{l}2.9 \\
(2.81)\end{array}$ & $\begin{array}{l}-7.7 \\
(-9.3)\end{array}$ & $\begin{array}{l}<0.01 \\
(<0.01)\end{array}$ & $\begin{array}{l}1.28 \\
(1.34)\end{array}$ & $\begin{array}{l}1.39 \\
(1.41)\end{array}$ & $\begin{array}{l}-3.8 \\
(-3.6)\end{array}$ & $\begin{array}{l}<0.01 \\
(<0.01)\end{array}$ \\
\hline
\end{tabular}


Table B-14 Case Study 2 Evening: Roadside NO and $\mathrm{NO}_{2}$ (cuberoot transformed) t-test results for unmatched and matched samples. Full datasets are in parentheses.

\begin{tabular}{|l|l|l|l|l|l|l|l|l|}
\hline Data Subset & $\begin{array}{l}\text { CR- NO } \\
\text { Control }\end{array}$ & $\begin{array}{l}\text { CR- NO } \\
\text { Trmt }\end{array}$ & $\begin{array}{l}\text { CR- NO } \\
\text { t-value }\end{array}$ & $\begin{array}{l}\text { CR- NO } \\
\text {-value }\end{array}$ & $\begin{array}{l}\text { CR- NO2 } \\
\text { Control }\end{array}$ & $\begin{array}{l}\text { CR- NO2 } \\
\text { Trmt }\end{array}$ & $\begin{array}{l}\text { CR- NO2 } \\
\text { t-value }\end{array}$ & $\begin{array}{l}\text { CR- NO2 } \\
\text {-value }\end{array}$ \\
\hline $\begin{array}{l}\text { Unmatched } \\
5 \text { min }\end{array}$ & 2.41 & 2.63 & -3.7 & $<0.01$ & 2.39 & 2.61 & -5.6 & $<0.01$ \\
$(2.41)$ & $(2.51)$ & $(-3.8)$ & $(<0.01)$ & $(2.39)$ & $(2.6)$ & $(-9.3)$ & $(<0.01)$ \\
\hline $\begin{array}{l}\text { Matched } \\
5 \text { min }\end{array}$ & 2.26 & 2.63 & -4.9 & $<0.01$ & 2.31 & 2.61 & -5.6 & $<0.01$ \\
$(2.41)$ & $(2.5)$ & $(-3)$ & $(<0.01)$ & $(2.39)$ & $(2.57)$ & $(-8.5)$ & $(<0.01)$ \\
\hline $\begin{array}{l}\text { Unmatched } \\
15 \text { min }\end{array}$ & 2.49 & 2.63 & -2.6 & 0.01 & 2.45 & 2.61 & -1.62 & $<0.01$ \\
$(2.49)$ & $(2.58)$ & $(-2.2)$ & $(0.03)$ & $(2.45)$ & $(2.63)$ & $(-6.7)$ & $(<0.01)$ \\
\hline $\begin{array}{l}\text { Matched } \\
15 \text { min }\end{array}$ & 2.4 & 2.64 & -3.7 & $<0.01$ & 2.43 & 2.61 & -4.3 & $<0.01$ \\
\hline
\end{tabular}


Table B-15 Case Study 2 Evening: Background NO and $\mathrm{NO}_{2}$ (cuberoot transformed) t-test results for unmatched and matched samples. Full datasets are in parentheses.

\begin{tabular}{|c|c|c|c|c|c|c|c|c|}
\hline Data Subset & $\begin{array}{l}\text { DEQ NO } \\
\text { Control }\end{array}$ & $\begin{array}{l}\text { DEQ NO } \\
\text { Trmt }\end{array}$ & $\begin{array}{l}\text { DEQ NO } \\
\text { t-value }\end{array}$ & $\begin{array}{l}\text { DEQ NO } \\
\text { p-value }\end{array}$ & $\begin{array}{l}\mathrm{DEQ} \mathrm{NO} 2 \\
\text { Control }\end{array}$ & $\begin{array}{l}\text { DEQ } \mathrm{NO}_{2} \\
\text { Trmt }\end{array}$ & $\begin{array}{l}\mathrm{DEQ} \mathrm{NO}_{2} \\
\text { t-value }\end{array}$ & $\begin{array}{l}\mathrm{DEQ} \mathrm{NO} \\
\text { p-value }\end{array}$ \\
\hline $\begin{array}{l}\text { Unmatched } \\
5 \mathrm{~min}\end{array}$ & $\begin{array}{l}1.09 \\
(1.09)\end{array}$ & $\begin{array}{l}0.95 \\
(0.96)\end{array}$ & $\begin{array}{l}6.1 \\
(15.3)\end{array}$ & $\begin{array}{l}<0.01 \\
(<0.01)\end{array}$ & $\begin{array}{l}1.89 \\
(1.89)\end{array}$ & $\begin{array}{l}1.96 \\
(1.92)\end{array}$ & $\begin{array}{l}-1.9 \\
(-1.7)\end{array}$ & $\begin{array}{l}0.06 \\
(0.1)\end{array}$ \\
\hline $\begin{array}{l}\text { Matched } \\
5 \mathrm{~min}\end{array}$ & $\begin{array}{l}1.09 \\
(1.09)\end{array}$ & $\begin{array}{l}0.95 \\
(0.95)\end{array}$ & $\begin{array}{l}5.4 \\
(15.1)\end{array}$ & $\begin{array}{l}<0.01 \\
(<0.01)\end{array}$ & $\begin{array}{l}1.89 \\
(1.89)\end{array}$ & $\begin{array}{l}1.96 \\
(1.9)\end{array}$ & $\begin{array}{l}-1.5 \\
(-1)\end{array}$ & $\begin{array}{l}0.13 \\
(0.3)\end{array}$ \\
\hline $\begin{array}{l}\text { Unmatched } \\
15 \mathrm{~min}\end{array}$ & $\begin{array}{l}1.1 \\
(1.1)\end{array}$ & $\begin{array}{l}0.95 \\
(0.96)\end{array}$ & $\begin{array}{l}7 \\
(10.3)\end{array}$ & $\begin{array}{l}<0.01 \\
(<0.01)\end{array}$ & $\begin{array}{l}1.87 \\
(1.87)\end{array}$ & $\begin{array}{l}1.93 \\
(1.9)\end{array}$ & $\begin{array}{l}-1.5 \\
(-1.2)\end{array}$ & $\begin{array}{l}0.13 \\
(0.23)\end{array}$ \\
\hline $\begin{array}{l}\text { Matched } \\
15 \mathrm{~min}\end{array}$ & $\begin{array}{l}1.09 \\
(1.1)\end{array}$ & $\begin{array}{l}0.95 \\
(0.96)\end{array}$ & $\begin{array}{l}6 \\
(9.7)\end{array}$ & $\begin{array}{l}<0.01 \\
(<0.01)\end{array}$ & $\begin{array}{l}1.95 \\
(1.87)\end{array}$ & $\begin{array}{l}1.93 \\
(1.88)\end{array}$ & $\begin{array}{l}0.48 \\
(-0.6)\end{array}$ & $\begin{array}{l}0.63 \\
(0.54)\end{array}$ \\
\hline
\end{tabular}


C. Appendix C: Cascades to Coast GK-12 Curriculum

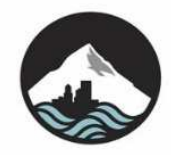

CASCADES TO COAST

GK12 FELLOWSHIP

Portland Sunivensiry

Cascades to Coast GK12 Curriculum

Nitrogen Dioxide Inquiry: Measuring Air Pollution in Your Own Neighborhood

Fellow: Christine Kendrick (Environmental Science)

Teacher: Kathy Childress (Gresham High School)

Advisor: Dr. Linda George (Environmental Science)

\section{Learning Goal:}

- Develop, conduct, analyze, and present the results of an inquiry-based field study on air pollution in the local neighborhood or surrounding environment of the school.

\section{Learning Objectives:}

- Introduce the concept of combustion and air pollutants, specifically nitrogen dioxide $\left(\mathrm{NO}_{2}\right)$, sources, and environmental and health impacts

- Introduce students to note taking through a presentation on $\mathrm{NO}_{2}$ background information

- Introduce the nitrogen dioxide passive sampler technique to measure $\mathrm{NO}_{2}$

- Have students develop a research question and conduct a study based on air quality lesson using the passive sampler method

- Have students map $\mathrm{NO}_{2}$ concentration values using GoogleEarth and data analysis to compare values at different sites

- Students will present and communicate their study methods, results, and conclusions in class presentations using PowerPoint

Target Grade: $9^{\text {th }}$ Grade 


\section{State Standards:}

H.2P.1 Explain how chemical reactions result from the making and breaking of bonds in a process that absorbs or releases energy

H.2E4 Evaluate the impact of human activities on environmental quality and the sustainability of Earth systems.

H.3S.2 Design and conduct a controlled experiment, field study, or other investigation to make systematic observations about the natural world, including the collection of sufficient and appropriate data.

H.3S.3 Analyze data and identify uncertainties. Draw a valid conclusion, explain how it is supported by the evidence, and communicate the findings of a scientific investigation.

\section{Activity Summary:}

Students will learn about combustion and the creation of nitrogen dioxide as an air pollutant and its effects through an interactive lecture on the white board and take notes. Students will also learn about passive samplers for measuring nitrogen dioxide through a demonstration.

Students will then develop their own inquiry/research question for a field study using the passive samplers. Students will carry out the measurement campaign, analyze the tubes as a class, and then create class presentations including background on their research question, methods, results, conclusions, errors, and future questions therefore modeling a scientific research study.

\section{Timeline: (more details about activities provided in below in Activity Plan)}

\section{$\underline{\text { First class period (90 minutes): }}$}

Give students a presentation on combustion as source of nitrogen dioxide, describe sources, health and environmental impacts. Presentation is given using a white or chalkboard so students can contribute answers and have the lecture/presentation be more interactive. Also introduce what the passive samplers are, how they work overall, and how to setup the samplers at chosen study sites. 
Second class period ( 90 minutes):

Have students break into groups and come up with 3 examples of research questions/hypotheses. List group questions on board and discuss as a whole class. Then have each group decide on most interesting question and develop an experimental design.

\section{Third class period (60 minutes):}

Have each group describe their question and research plan (where to place the tubes (passive samplers)) to the whole class. Hand out the samplers. Students will take home or place them in the field (indoor or outdoor environments) as proposed in their study design, this will take place outside of class.

Samplers are left out in the field for approximately 2 weeks.

Fourth class period (90 minutes):

Students are required to bring the samplers back into class. Chemistry of the analysis is discussed and students interested will help analyze all of the samplers (graduate student + 6 students). Values will be determined and students will begin to map values onto GoogleEarth maps. Students are also working simultaneously on slides for presentations.

Fifth class period (90 minutes): Class time to complete the presentations and conclusions. Begin presentations if students ready.

Sixth class period (90 minutes): Students continue to give presentations on their field study and research question. 


\section{Activity Plan:}

\section{First Class Period- Introduction}

Activity begins with an air quality lecture from visiting scientist/graduate student using only drawing and listing on the white board in front of the class with participation from the students answering questions as the lecture progresses. The lecture does not use Powerpoint so that this presentation is more interactive and students are participating in creating the background knowledge. The lecture covers the composition of the atmosphere, what happens to gasoline or diesel in the engine of a motor vehicle (introducing combustion), sources of $\mathrm{NO}_{2}$ pollution (anthropogenic and natural), and why do we care (human health, environmental factors like acid rain and eutrophication, etc.). Students are required to take notes in science spiral notebook they bring to class everyday under each topic of the lecture (what happens in combustion, sources of $\mathrm{NO}_{2}$, and impacts of $\mathrm{NO}_{2}$ ). If teachers chooses, you could use assessments such as "one sentence summary" or have students write "one thing I learned, one thing that was not clear, and one thing I would like to learn more about" and turn in after the lecture.

\section{Research Development}

Then scientist or teacher introduces the sampling technique by bringing in the samplers and showing the pieces of the samplers, the general mechanism of how the sampler measures $\mathrm{NO}_{2}$, and how to set up in the field (indoor or outdoor environment). See pdf of instructions attached for step by step details on assembly and analysis and Figure 1 for description of tube (sampler).

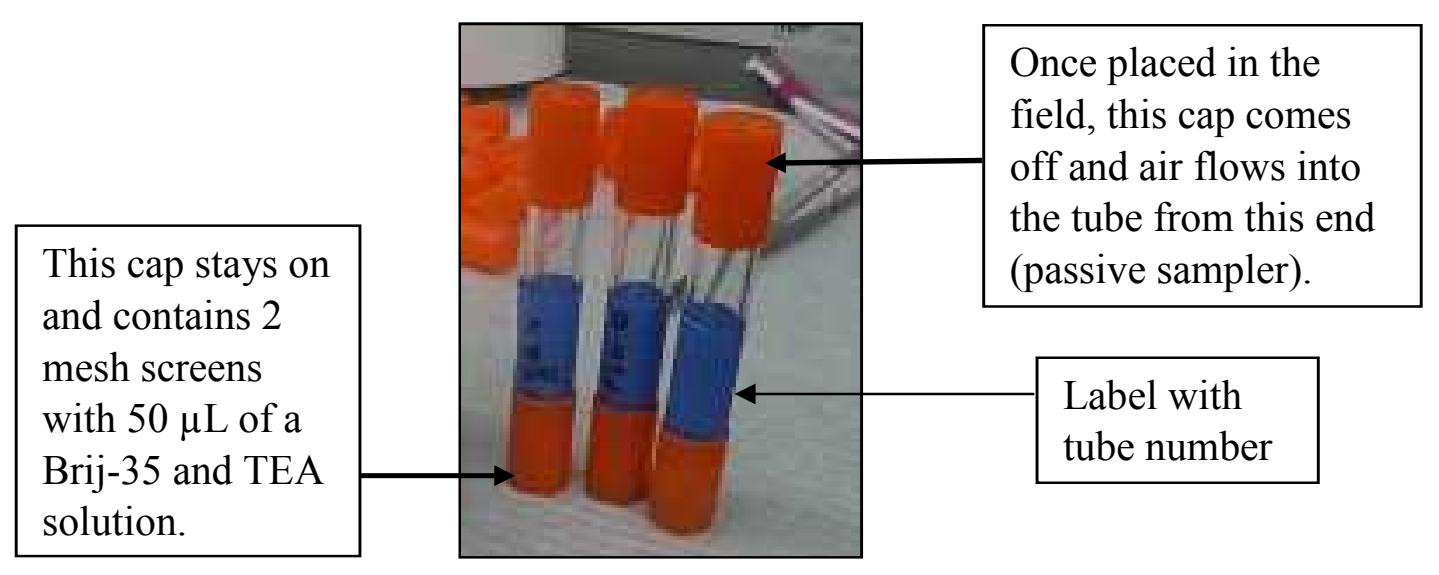

Figure C-1 Image of three $\mathrm{NO}_{2}$ Passive Samplers. 
The mesh screens provide a place for the Brij-35 and TEA solution to attach too. The Brij-35 is a wetting agent and helps spread out the TEA and helps it stick to the mesh screens. The TEA is the chemical that will react with nitrogen dioxide from the air that passes into the tube. The tubes are left out in the field for approximately 14 days, then recapped and analyzed.

For analysis, distilled water and a sulfanilamide-NEDA solution will be added to each tube and you let the reaction stand for 15 minutes. The solution in the tube will become pink. The coloring is the result of the NEDA dye reacting with $\mathrm{NO}_{2}$ captured by the tubes while out in the field.

The solution in the tubes is then poured into cuvettes and the absorbance of each solution is measured using a spectrometer, like the Spectronic-20 pictured below. The spectroscopic analysis will shine a light through the cuvette and measure how much light is absorbed at the wavelength of 540nm (appropriate for the pink color in the reaction). The higher absorbance, the higher the $\mathrm{NO}_{2}$ concentration. The instructions then have calculations to convert the absorbance into a $\mathrm{NO}_{2}$ concentration at the ppb level (graduate student will conduct calculations and provide $\mathrm{NO}_{2}$ concentration values to the student during analysis not the absorbance values).

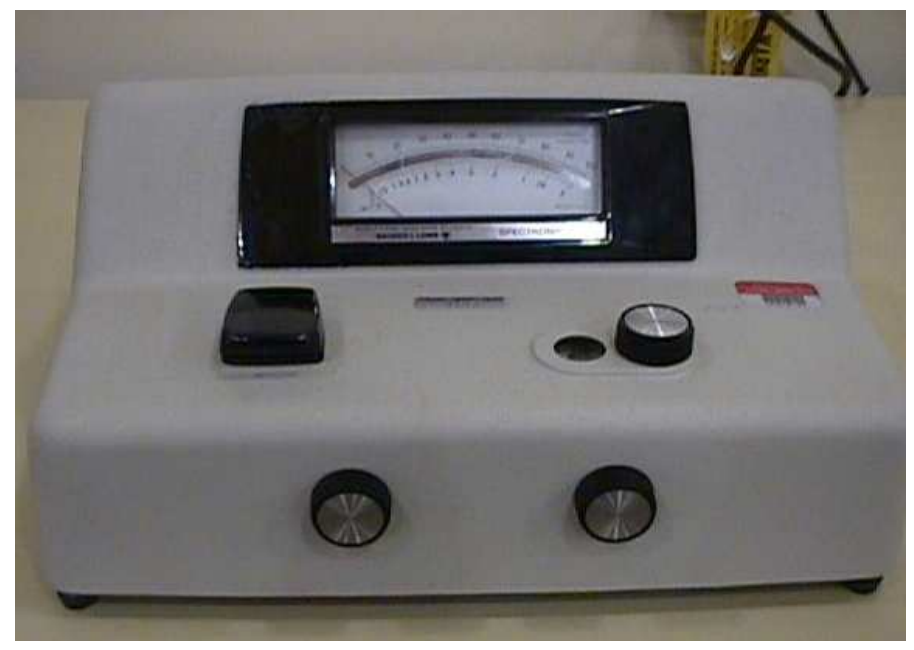

Figure C-2 Image of Spectronic-20, an example of a simple spectrometer that can be used for analysis of $\mathrm{NO}_{2}$ passive samplers. 


\section{Second and Third Class Periods- Develop Field Protocols}

Students are broken up into groups. For a class size of 36, we did six students per group. Then given time to brainstorm ideas of research questions or places they would like to put the passive samplers and measure $\mathrm{NO}_{2}$ or compare $\mathrm{NO}_{2}$ levels. Each group should come up with 3 ideas or research questions.

As a class we will write study questions from the groups on the board and discuss each idea. Is it feasible to place samplers where the students have come up with? Will the question they asked be possible to answer using the passive samplers? Are there ways to improve or alter the question so study design is improved? We will also discuss possible sampler locations for the questions. For example, many students typically come up with the question of measuring $\mathrm{NO}_{2}$ concentrations at a fast food drive through versus inside the restaurant but it is highly unlikely for a private restaurant to let students place the samplers there.

Then students will go back into their groups and decide on one research question they will carry out for a field study. Students are instructed that for each group of six students, they will be getting $24 \mathrm{NO}_{2}$ samplers The students must decide on a protocol of where to place the samplers and who will do what.

If there is time, each group will present verbally to the class the decided upon research question and the locations they will plan to place samplers. This gives an extra opportunity for feedback from the teacher, graduate student, and class. This step also ensures the students have come up with a detailed study plan.

Examples of successful questions from past classes

- "What is the effect of a straight neighborhood road versus living on a court with less through traffic? We will place 12 samplers on two straight roads with similar traffic levels and the other 12 on two courts with similar number of residences."

- "Is there a difference in $\mathrm{NO}_{2}$ levels at the front of the school versus the back where there are parking lots?"

Passive samplers already assembled and labeled with numbers are then handed out to each group. The students are given zip-ties and wire to attach samplers to field sites.

Students will place samplers in the field outside of class time and need to record the following: 
- Number and location of each tube

- Date and time uncapped

This information will go onto the same page in their science spiral notebooks with the $\mathrm{NO}_{2}$ lecture notes. No additional data sheet is provided. For $9^{\text {th }}$ grade, they use a spiral notebook in class throughout the whole year that they bring to class each day.

\section{Samplers are left out in the field for $\mathbf{2}$ weeks and reminders are given to students when they need to bring the tubes back into the classroom.}

\section{Fourth, Fifth, and possibly Sixth Class Periods- Analysis and Presentations}

Volunteers interested in chemistry conduct the analysis with the graduate student so about six students per class are working on the analysis protocol (see detailed steps and equipment list in attached pdf).

Other group members are marking locations of samplers on GoogleEarth maps on the computer and board with the class. As concentration values are determined using the spectrometer, values are given to the groups and students put on the map. Students use the data to determine the answer to their question or if their question has been answered. Data analysis may include calculating the mean concentrations for sites with different environmental conditions (for example the mean value of $\mathrm{NO}_{2}$ at the front of the school vs mean value of $\mathrm{NO}_{2}$ at the back of the school near the buses). Data analysis may also include calculating concentrations differences or possibly a statistical t-test if this method is taught in class lessons before the $\mathrm{NO}_{2}$ inquiry.

All other group members are preparing slides for a PowerPoint presentation. Each presentation should have the following slides:

- Title slide with a descriptive title relating to the group's research question and names of group members (1 slide)

- Introduction with research question and some background information on why we might care about $\mathrm{NO}_{2}$ (health or environmental impacts) (1 slide)

- Methods relating to where they placed their samplers, not about the actual samplers since the whole class used the same method (1 slide)

- Results including a map of the values and another slide with data analysis results (means, differences, greater or less than statements) (2 slides) 
- Conclusions, answer to their research question, and overall what they found out (1-2 slides)

- Sources of error and possible future question. Describe error such as forgot caps to close the tubes when picking them back up, dropped tubes in the mud, didn't record the location or time uncapped and re-capped accurately, and what type of question might you ask next related to the current findings (1-2 slides)

Each group will give a presentation to the class and each student in the group is required to speak some component of the presentation.

Related Concepts: weather, climate, chemistry, inquiry

\section{Materials:}

- Instructions to prepare and analyze passive nitrogen dioxide sampler (list of materials within this set of instructions), see accompanying pdf file.

- Access to computers to make research presentations

Handouts and worksheets: Students will take notes during the air quality lecture and the notes will be a required entry in each student's science/lab spiral. The students are free to write the notes in any fashion but just need some notes for each topic as described above in the Activity Plan, Introduction. The second half of this notebook page will be used to record the location, date, and time uncapped and re-capped for the samplers that student puts out in the field.

Extensions: Can use the passive $\mathrm{NO}_{2}$ sampler method for future inquiry projects and Science Fair projects. We introduce this inquiry a few weeks before they are supposed to design a science fair project. Also, air pollution concepts introduced in this lesson are built on to conduct a similar inquiry project concerning particles in the air. The air quality lessons are also used to develop air quality research questions in the spring Cascades to Coast project. An additional possible extension is to have the students present their findings to a middle or elementary or another high school science class to extend the communication piece of this lesson and possibly count towards community service.

Assessment: Clarity of the presentations, students can explain their study design and how confident they feel their results answer the study question, and presentations have all components (title, introduction and background on research question, methods relate to their particular study design, results, conclusions, errors, and future questions). 


\section{GK12 Inquiry Activity: Ultrafine Particles}

Fellow: Christine Kendrick (Environmental Science)

Teacher: Kathy Childress (Gresham High School)

Advisor: Dr. Linda George (Environmental Science)

\section{Learning goals:}

- Expand on prior knowledge of air quality and introduce the definition and sources of particulate matter and specifically ultrafine particles $(<.1 \mu \mathrm{m})$

- Introduce an example of a scientific poster and presentation, thus introducing outcomes of their upcoming research projects and scoring rubrics for future class presentations

- Have students develop a research question and conduct a mini-research study using a TSI P-Track instrument to measure ultrafine particle concentrations and can use a TSI DustTrak to measure larger size fractions of particles if their question needs such measurements

- Introduce mapping with data

Target Grade: $9^{\text {th }}$ Grade

\section{State Standards:}

H.2E4 Evaluate the impact of human activities on environmental quality and the sustainability of Earth systems.

H.3S.2 Design and conduct a controlled experiment, field study, or other investigation to make systematic observations about the natural world, including the collection of sufficient and appropriate data.

\section{Activity Summary:}

Students will learn about particulate matter, air quality standards, and the definition and sources of ultrafine particles, a very small size fraction of particulate matter. Students will then learn about the research of the graduate student through listening to a PowerPoint presentation on the various research projects the graduate student has worked on and learn about the experience the student has had in conducting such work including research questions, methods, results, and what it is like working along roadways. Equipment such as the TSI P-Trak Ultrafine Particle Counter and DustTrak to measure 
mass concentrations of particulate matter will be brought in and demonstrated to the class. Students will have a question and answer period with the graduate student and then set to a mini-challenge to come up with a research question that could be answered using the equipment brought in and the weather station at the school. Students will vote on the most intriguing question and then a mini-study will be carried out with the group of students who developed the question. Data will be brought in after going out in the field and mapped as a class.

\section{Activity Plan:}

Using PowerPoint and a projector, the graduate student will begin by explaining research interests and story of how scientific interest led them to air quality research. The presentation will then continue with background information on particulate matter, air quality standards and the Clean Air Act, and then specific background on ultrafine particles. The presentation will then continue with actual slides from presentations given at scientific conferences so the students learn about a new aspect of the graduate student's job and the research projects the student has been involved in. The presentation will end with a slide of an example of a scientific poster and posters brought in to leave in the classroom as well. The graduate student will have a question and answer period for about 15 minutes with the $9^{\text {th }}$ graders.

Second, the graduate student will introduce two pieces of equipment seen in the presentation called the TSI P-Trak ultrafine particle counter to measure ultrafine particles and the TSI DustTrak to measure larger size fractions of particulate matter. The students will be able to handle the equipment, move dust around, etc and see changes in the values in the measurements.

Split into groups, the students will come up with what they think is an interesting question regarding particles and can be answered by using the equipment brought in. As a class, all of the questions will be listed on the board and then a vote on the question everyone would like to see the results of conducted. Whichever group came up with the most voted on question gets to head outside the class with the graduate student and do a mini-measuring campaign using the equipment. Values recorded will be brought back into the classroom and will be mapped as a class. Then a discussion of the values found will follow, noting on any unexpected results, etc.

Related Concepts: weather, climate, inquiry, air quality, presentation skills 


\section{Materials:}

- Research presentation and poster from a science graduate student

- TSI P-Trak ultrafine particle counter

- TSI DustTrak particle monitor

Handouts and worksheets: Specified pages in lab notebooks for student notes from the presentation

Extensions: Equipment and air quality parameters introduced with this lesson are used in the spring measurements on the Cascades to Coast field

Assessment: Types of questions asked by the students in the question and answer period following the presentation and participation in research question development 


\title{
Cascades to Coast GK-12 Field Trip Inquiry:
}

\section{How does land use affect air and water quality?}

\author{
Fellow: Christine Kendrick (Environmental Science) \\ Teacher: Kathy Childress (Gresham High School) \\ Advisor: Dr. Linda George (Environmental Science)
}

The previous two pieces of curriculum presented in Appendix $\mathrm{C}$ are examples of class activities conducted with $9^{\text {th }}$ grade science students to introduce measurement methods, research question development, and presentation of inquiry-based results necessary to complete the final field trip inquiry activity towards the end of the school year. Examples of additional class activities throughout the year are a small field trip to a local park to practice water quality assessment techniques and an in-class macroinvertebrate bioassessment project.

The field trips involved field data collection of water and air quality variables at three different locations with varying land uses (Figure C-3). Figure C-3a is an urban location, Main City Park along Johnson Creek. Figure C-3b is a rural location dominated by agriculture land uses such as nurseries, Stone road also along Johnson Creek. Figure C-3c is a forested area called Metzler Park along Clear Creek. Students had the choice of several water and air quality variables to measure at each site. At each location, three groups each measured the water quality variables of dissolved oxygen, percent of EPT macroinvertebrates, turbidity, streamflow, nitrate, and conductivity. Air quality variables included particle number concentrations, $\mathrm{PM}_{2.5}$ and $\mathrm{PM}_{10}$ mass.
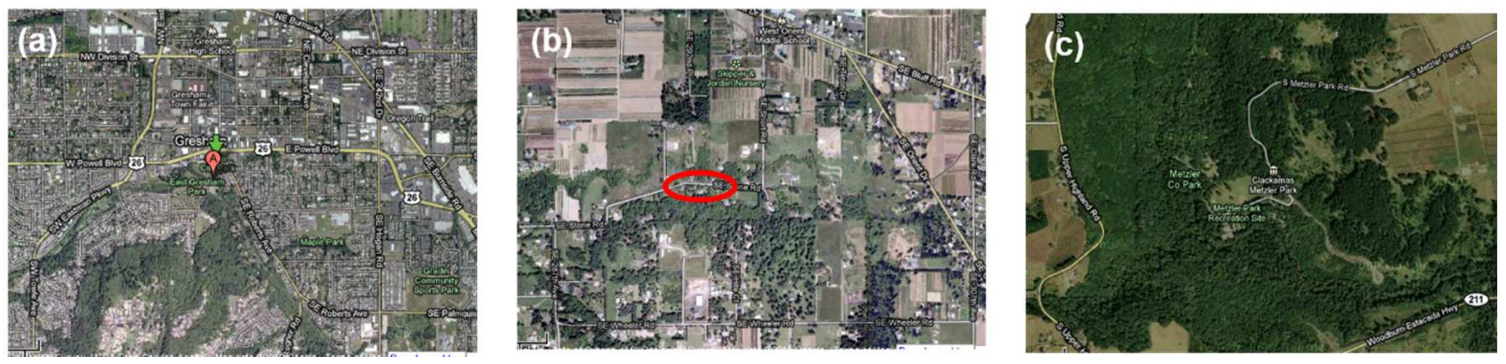

Figure C-3 Images of the three field trip locations showing varying land use. (a) Urban: Main City Park, Gresham, OR, (b) Rural: Stone Road, Gresham, OR, (c) Forested: Metzler Park, Estacada, OR. 
After the field trips and data collection were complete, students decided on a research question that they could answer using one or more of the variables measured at the three sites under the umbrella topic of the effect of land use on air and water quality. Average particle number concentration data collected at all three sites in 2011 are shown in Figure $\mathrm{C}-4$. The highest PNCs were found at the urban location closest to sources of traffic.

Very low PNC values were found at the forested site demonstrating background concentrations when no large traffic sources are present. Figure C-5 shows an example of the type of analysis and research questions the students could develop using the measured variables and some additional research.

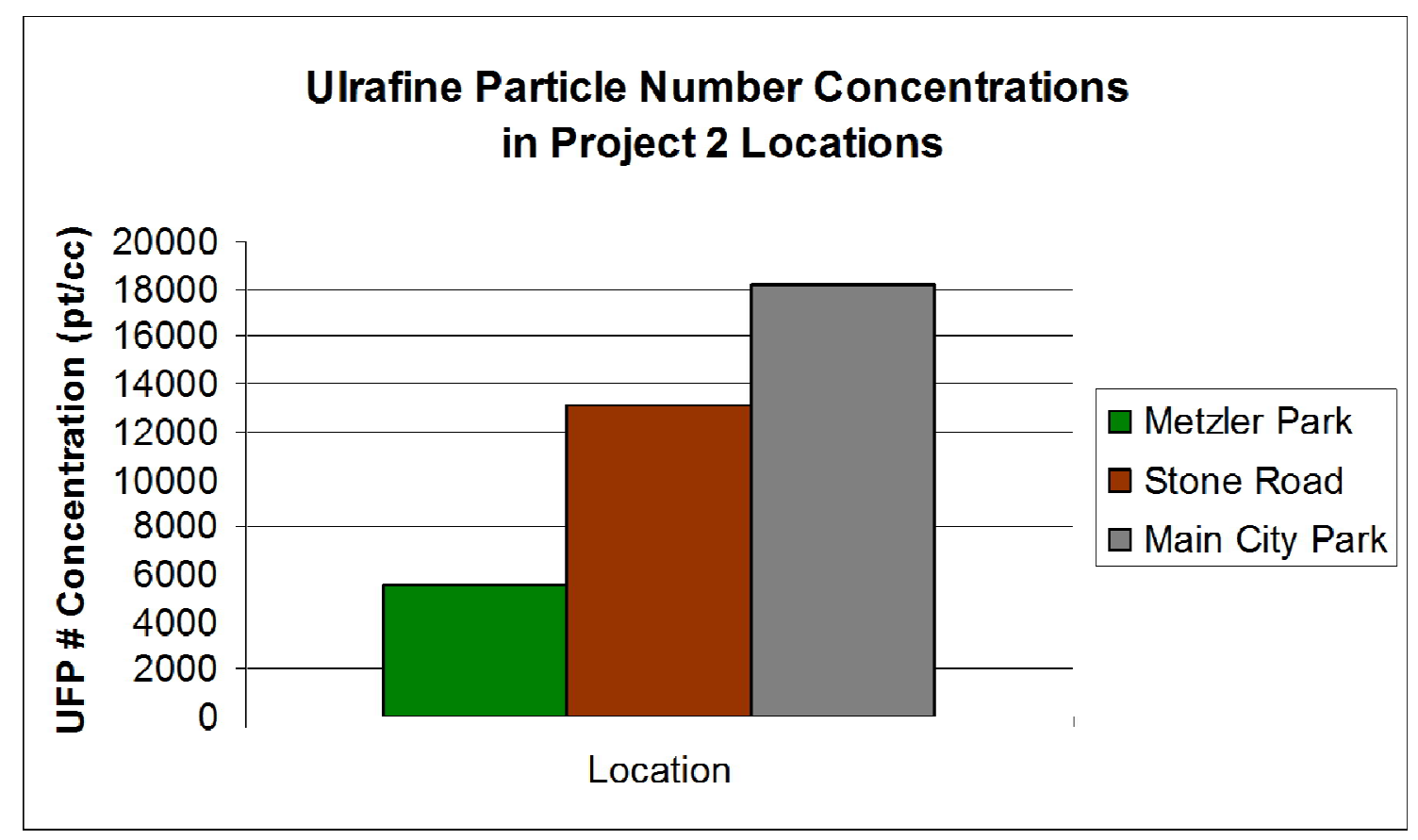

Figure C-4 Average particle number concentrations measured in the three field strip sites with urban, rural, and forested land uses. 


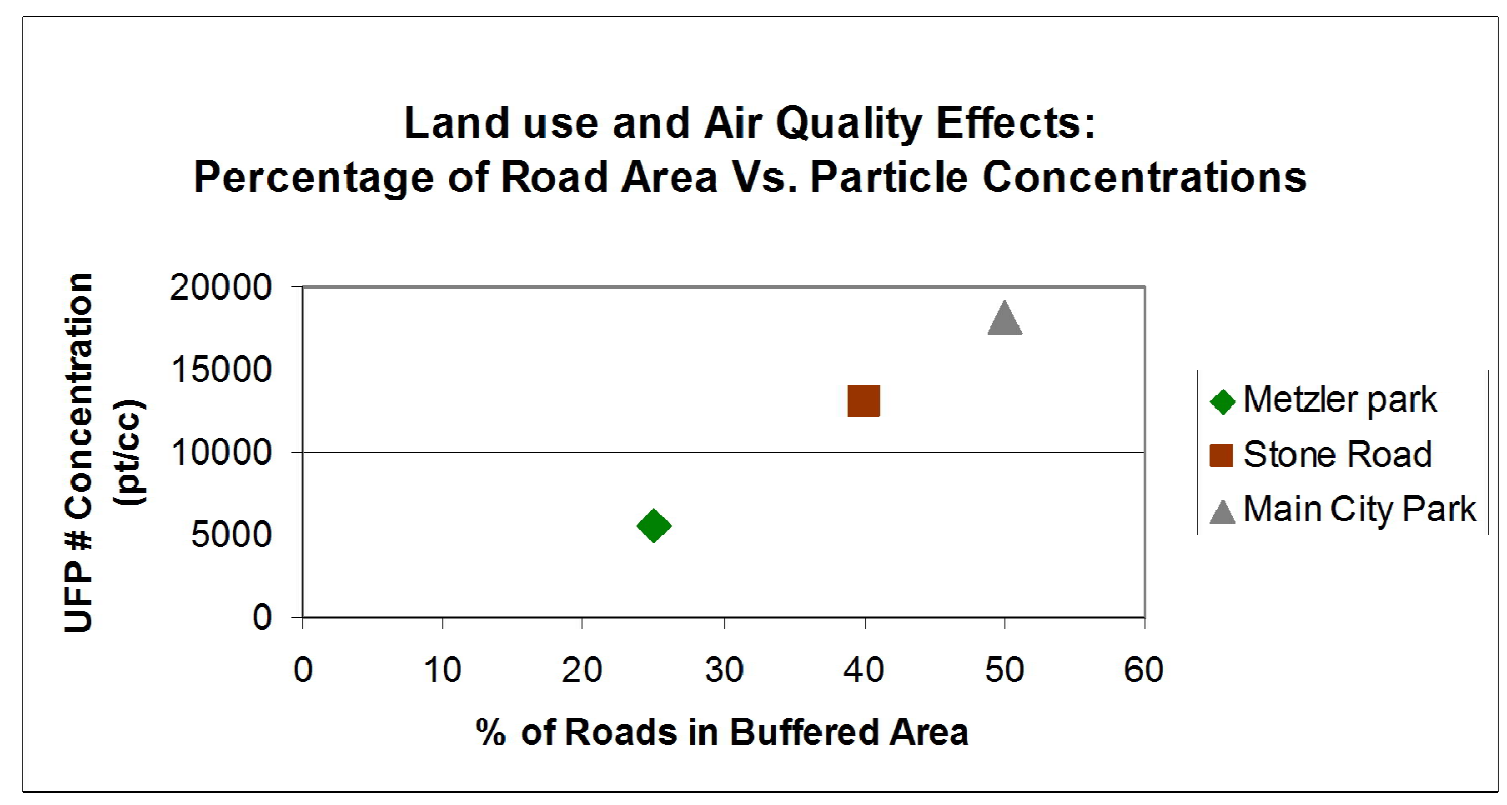

Figure C-5 Example of the type of research question and project the students could develop based on field collected data. 